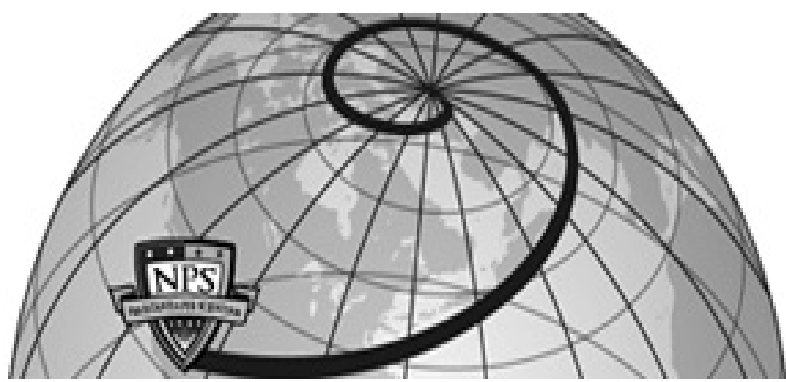

Calhoun: The NPS Institutional Archive DSpace Repository

2001

\title{
Strategy in the contemporary world
}

\section{Wirtz, James}

Monterey, California. Naval Postgraduate School

http://hdl.handle.net/10945/658

Downloaded from NPS Archive: Calhoun

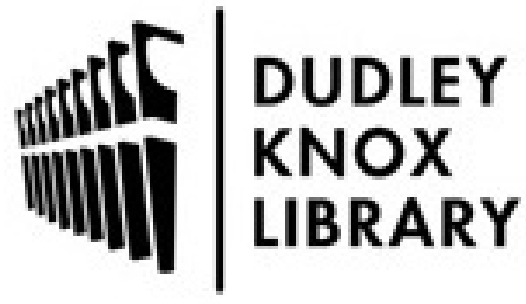

http://www.nps.edu/library
Calhoun is the Naval Postgraduate School's public access digital repository for research materials and institutional publications created by the NPS community. Calhoun is named for Professor of Mathematics Guy K. Calhoun, NPS's first appointed -- and published -- scholarly author.

Dudley Knox Library / Naval Postgraduate School 411 Dyer Road / 1 University Circle Monterey, California USA 93943 


\section{STRATEGY IN THE CONTEMPORARY WORLD}

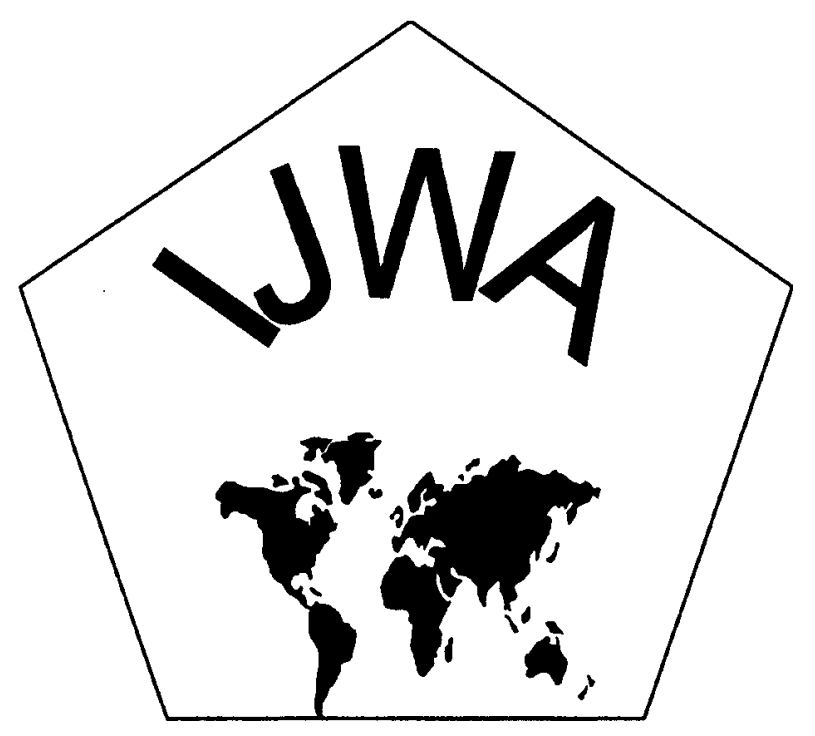

DISTRIBUTION STATEMENTA

Approved for Public Release

Distribution Unlimited

James Wirtz

\section{4}

The Institutefor Joint Warfare Analysis

Naval Postgraduate School

Monterey, California 
NPS-IJWA-01-005

\section{STRATEGY IN THE CONTEMPORARY WORLD}

James Wirtz 


\section{INSTITUTE FOR JOINT WARFARE ANALYSIS \\ NAVAL POSTGRADUATE SCHOOL Monterey, California}

RADM David R. Ellison

Richard Ester

Superintendent

Provost

This report was prepared for and funded by:

Joint Experimentation command and

Office of Naval Research

through the CDTEMS program

This report was prepared by:

Institute For Joint Warfare Analysis

Naval Postgraduate School

Monterey, CA

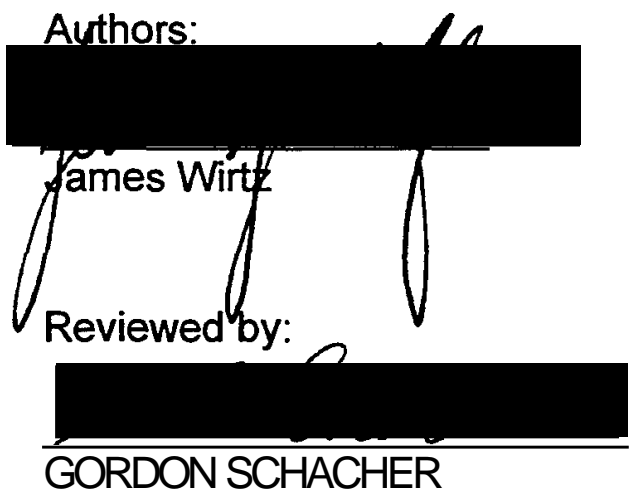

Director

Institutefor Joint Warfare Analysis

Released by:

DAVID W. NETZER

Associate Provost and

Dean of Research 


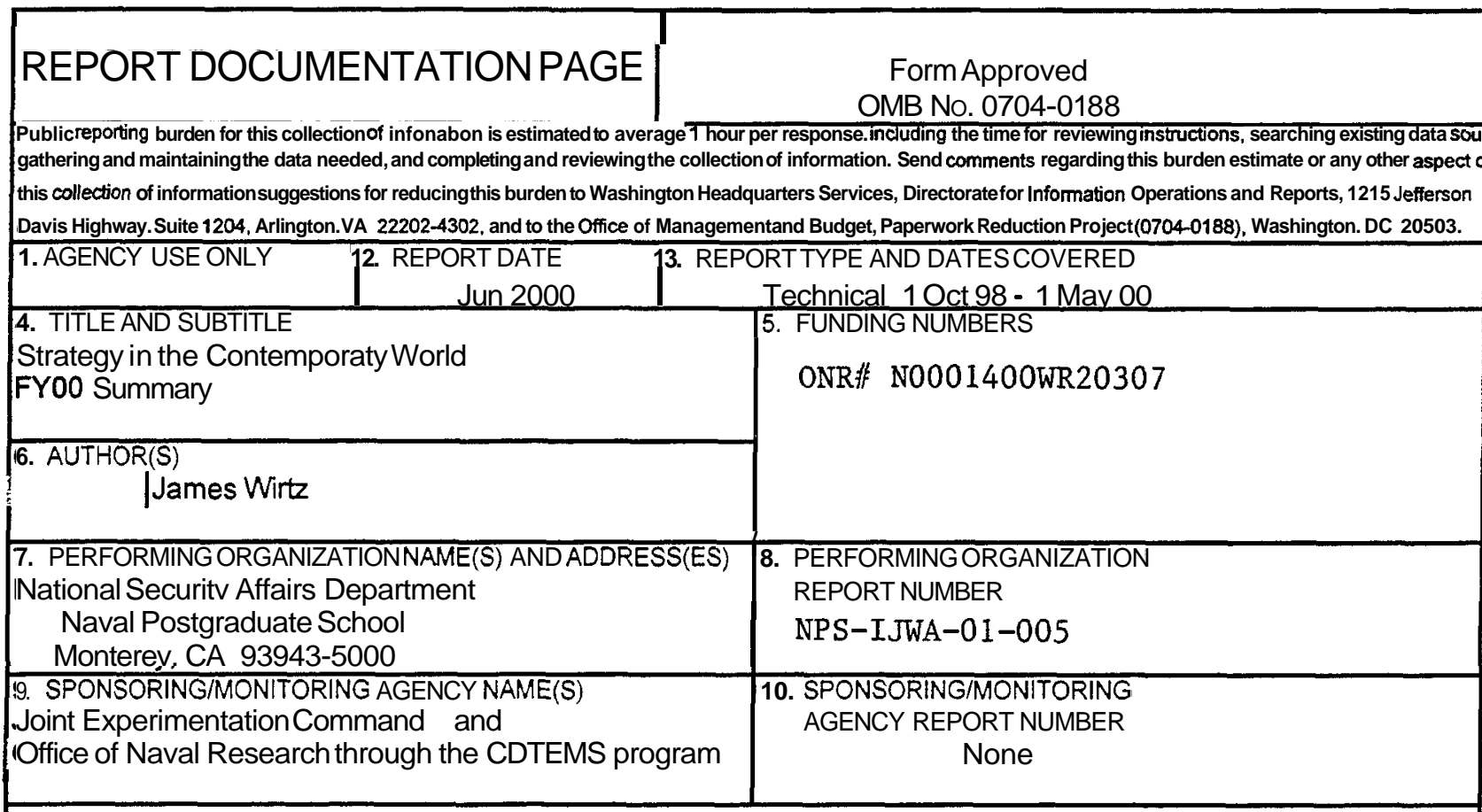

The views expressed in this thesis are those of the author and do not reflect the official policy or position of the Department of Defense or the U.S. Government

\begin{tabular}{l|l|l}
\hline 12A. DISTRIBUTION/AVAILABILITY STATEMENT & 12b. DISTRIBUTIONCODE
\end{tabular}

Approved for public release; distribution is unlimited

13. ABSTRACT (maximum200 words)

:Since the end of the Cold War, naval analysts and strategists have faced a crisis. On the one hand, they are well versed with the enduring concepts of strategy, intelligenceand the procedures and lessons generated by nearly fifty years of Cold War. On the other hand, there is a widespread notion that traditional ways of doing business undermine new, more cooperative opportunities that have arisen in international politics since 1989. This criticism is reflected in attempts at "New Thinking" which places societal, environmental and even "Utopian"solutions to military and intelligence problems ahead of traditional concepts of strategy. At the same time, events like the GulfWar, Bosnia, Kosovo, Desert Fox and "intelligence surprises" (Indian and Pakistan nucleartesting) demonstrate a mastery of the principles of intelligence and strategy are the cornerstone of U.S. foreign and defense policy.

\begin{tabular}{|c|c|c|}
\hline \multicolumn{2}{|l|}{$\begin{array}{l}\text { 14. SUBJECT TERMS } \\
\text { National Strategy }\end{array}$} & $\begin{array}{r}\text { 15. NUMBER OF PAGES } \\
124 \\
\end{array}$ \\
\hline $\begin{array}{l}\text { 17. SECURITY CLASSIFICATION } \\
\text { OF REPORT }\end{array}$ & 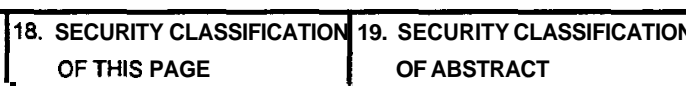 & 20. LIMITATIONOFABSTRACT \\
\hline Unclassified & Unclassified $\quad$ Unclassified & UL \\
\hline NSN 7540-01-280-5500 & & $\begin{array}{l}\text { Standard Form } 298 \text { (Rev 2-89) } \\
\text { Prescribed by ANSI Std Z39-18 } \\
298-102\end{array}$ \\
\hline
\end{tabular}




\section{Summary}

Since the end of the Cold War, naval analysts and strategists have faced a crisis. On the one hand, they are well versed with the enduring concepts of strategy, intelligence and the procedures and lessons generated by nearly fifty years of Cold War. On the other hand, there is a widespread notion that traditional ways of doing business undermine new, more cooperative opportunities that have arisen in international politics since 1989. This criticism is reflected in attempts at "New Thinking" which places societal, environmental and even "Utopian" solutions to military and intelligence problems ahead of traditional concepts of strategy. At the same time, events like the Gulf War, Bosnia, Kosovo, Desert Fox and "intelligence surprises" (Indian and Pakistan nuclear testing) demonstrate a mastery of the principles of intelligence and strategy are the cornerstone of U.S. foreign and defense policy.

\section{PROJECT DESCRIPTION}

To address these issues, several initiatives were undertaken in FYOO. First, the PI identified an international team of scholars to address issues of strategy in the contemporary world. An agenda was devised to explore several key themes of significance.

1. Enduring issues of Strategy: We will describe the evolution of strategic thought and the contribution of the key classical strategists (Thucydides to Clausewitz). We also will explore the perennial problems related to the relationship between force and morality and the causes of war.

2. Evolution of the Components of Joint Warfare: We will explore the theory and practice of land warfare, sea power and air power with an eye to placing post-Cold Werents in an historical context.

3. 20th Century Theories an Update: These authors will be asked to explore ideas about deterrence, arms control and disarmament, and terrorism and irregular warfare - ideas that preoccupied U.S. strategistsduring the Cold War - and update them to our present strategic circumstances.

4. Contemporary Issues of Grand Strategy: These contributors have been asked to evaluate new ideas about strategy and new issues that have emerged in the conduct of joint and combined operations since the end of the Cold War. We will explore the RMA, Spacewar and Cyberwar, the consequences of the proliferation of weapons of mass destruction, the explosion of humanitarian intervention peacekeeping operations, new environmental and social concerns that are emerging as issues of national security and the future of strategy as a topic of discourse among scholars and an educated officer corps. 


\section{FY 00 RESULTS}

A workshop held in Monterey California on 19-21 September 2000. Fourteen internationally renowned scholars presented their research on issues of strategy to a group of mid-level officers and policymakers. Participants exchanged ideas about refining the analyses presented and about crafting the papers into a coherent manuscript.

This report presents the conference working papers.

\section{FYOI COMPLETION OF THE PROJECT}

In FY01 conference participants will complete drafts of their papers. James Wirtz, Naval Postgraduate School and John Baylis, University of Wales will edit these drafts. The edited manuscript will then be provided to the sponsor by the summer of 2001 as the final deliverable for this project. This deliverable will form the basis of a major publication by Oxford University Press (in which conference sponsorship will be acknowledged). 


\section{STRATEGY IN THE CONTEMPORARY WORLD}

Workshop sponsored and organized by

Department of National Security Affairs, Naval Postgraduate School

Monterey, CA

19-21September, 2000

TUESDAY, 19 SEPTEMBER

6:00 - 9:00 Reception and Dinner

Stokes Adobe 500 Hartnell St. Monterey

WEDNESDAY, 20 SEPTEMBER

8:30 - 9:00 Registration

Mechanical Engineering Auditorium

Naval Postgraduate School

9:00 - 9:15 Welcome Aboard

Frank C. Petho, Capt., MSC., USN

Chairman, Dept. of National Security Affairs

9:15 - 9:45 Introduction and Orientation

JamesJ. Wirtz, Naval Postgraduate School

John Baylis, University d Wales

Eliot Cohen, SAIS

$9: 45-11: 45$

"Enduring Issues of Strategy"

The Great Tradition: Strategic Theory and the Histoy of War

Daniel Moran, Naval Postgraduate School

Force and Morality

Justin Morris, University o Hull

Causes of War, Conditions of Peace: Causes, Motives, Character

Jack Spence, King's College, London

11:45-1:00 Lunch

Hyatt Regency 1 Old Golf Course Rd Monterey

1:00 -2:45 "Evolution of Joint Warfare"

Land Power: Theoy and Practice

Steve Biddle, University of North Carolina

Sea Power: Theoy and Practice

Sam Tangredi, U.S. Navy

Air Power: Theoy and Practice

Sir Timothy Garden, King's College, London

$2: 45-3: 15$

Break 
Deterrence: Theoy and Practice

Dale Walton, National Institutefor Public Policy

Arms Control and Disarmament

John Baylis, University $f$ Wales

Terrorism and Irregular Warfare

James Kiras, Hull University

700-9130 Dinner

Montrio 414 Calle Principal Monterey

Speaker: Ambassador Ronald Lehman, LLNL

THURSDAY. 21 SEPTEMBER

$9: 00-11: 00$

"Contemporary Issues of Grand Strategy"

Technology and War; i RMAs, Spacewar and Cyberwar

Eliot Cohen, SAIS

Humanitarian Intervention $\mathcal{E}$ Peacekeeping

Theo Farrell, University of Exeter

A New Agenda for Security \& Strategy?

James Wirtz, Naval Postgraduate School

11:00 - 11:15 Break

11:15-12:00 Conference Wrap Up

The Editors

$\underline{\text { Participants }}$

1. John Baylis, University of Wales

2. Stephen Biddle, University of North Carolina

3. Eliot A. Cohen, Johns Hopkins SAIS

4. Timothy Garden, King's College, London

5. Justin Morris, University of Hull

6. Theo Farrell, University of Exeter

7. James Kiras, Hull University

8. Daniel Moran, Naval Postgraduate School

9. Jack Spence ,King's College, London

10. Sam Tangredi, U.S. Navy

11. Dale Walton, National Institute for Public Policy

12. JamesJ. Wirtz, Naval Postgraduate School 


\section{STRATEGY IN THE CONTEMPORARY WORLD}

\section{Participants}

John Baylis, University of Wales

Stephen Biddle, University of North Carolina

Eliot A. Cohen, Johns Hopkins SAIS

Timothy Garden, King's College, London

Justin Morris, University of Hull

Theo Farrell, University of Exeter

James Kiras, Hull University

Daniel Moran, Naval Postgraduate School

Jack Spence ,King's College, London

Sam Tangredi, U.S. Navy

Dale Walton, National Institute for Public Policy

JamesJ. Wirtz, Naval Postgraduate School

Charles Krupnick, US Air Force Academy

Lt. Col. Steven Boyd, USAF, Defense Threat Reduction Agency

Terry Heuring, Defense Threat Reduction Agency

Dennis L. Lunsford, National Security Agency

Lt. Col. Daniel L. Scott, USAF, USSTRATCOM

Robert W. Ramsey III, HQ US Air Force

Anthony Fainburg, Defense Threat Reduction Agency

Major J. Scott O'Meara, USMC, US Joint Forces Command

John Patrick Brady, Strategic Systems Program

Major Brent Talbot, USAF, INSS

Gil Bernabe, Defense Threat Reduction Agency

Commander Kevin Farrell, USN

Lt. Col. Todd Steiner 
Cross of the Tree Farm

Lingen

Bucknell

Shropshire

SY7 OEE

Telephone and fax: 01568770636

Mobile: 0370956791

Brief Curriculum Vitae

\section{Professor.Jack Spence}

Professor J. E. Spence was born in South Africa. He was educated at the University of the Witwatersrand and the London School of Economics.

Professor Spence has held a variety of academic appointments:

1958-60 Lecturer in History and Politics - University of Natal

1961-62 Rockefeller Junior Research Fellow - L.S.E.

1962-73 Lecturer, Senior Lecturer and Reader in Politics - University College, Swansea

1973-91 Professor and Head of Department of Politics - University of Lancaster

1981-87 Pro-Vice Chancellor- University of Leicester

1991-97 Director of Studies - Royal Institute of International Affairs, London

1997- $\quad$ Associate Fellow - Royal Institute of International Affairs, London

Professor Spence has also held visiting appointments at:

University of California

University of Cape Town

University of Witwatersrand, Johannesburg

University of Natal, Durban and Pietermaritzburg

University of Zimbabwe

He is an Honorary Fellow on University College, Swansea, and Staffordshire University. In 1997 he was awarded an Honorary Doctorate of Laws by the University of Witwatersrand, Johannesburg. In 1998, Prof. Spence was awarded an Honorary Doctorate from Trent University, Nottingham. He has published extensively in the field of southern African politics and has five books together with a large number of articles to his credit. He is a past president of the African Studies Association of the United Kingdom and the chairman of the British International Studies Association. He broadcasts regularly on BBC radio and television, and is the senior consultant on Africa to Oxford Analvtica.

Professor Spence also has served on advisory committees of the Foreign and Commonwealth Office and has lectured on South African politics to a large number of institutions in Britain and abroad. In addition, he has provided consultancy services to a number of British and South African companies. 


\section{NAVAL POSTGRADUATE SCHOOL FACULTY BIOGRAPHY}

JAMESJ. WIRTZ

Associate Chairman for Research, Department of National Security Affairs

Associate Professor

James J. Wirtz is an Associate Professor in the Department of National Security Affairs, Naval Postgraduate School, Monterey, California. He joined the School in 1990 after teaching at Franklin \& Marshall College, Penn State University and the State University of New York, Binghamton. He is the author of The Tet Offensive: Intelligence Failure in War (Cornell University Press, 1991, pbk 1994); co-editor with T.V. Paul and Richard Harknett of The Absolute Weapon Revisited: Nuclear Arms and the Emerging International Order (Michigan University Press, 1998); co-editor with Peter Lavoy and Scott Sagan of Planning the Unthinkable: New Powers and their Doctrines for Using Chemical, Biological and Nuclear Weapons (Cornell University Press, 2000) and co-editor with Eliot Cohen, Colin Gray and John Baylis of Strategy in the Contemporay World (Oxford, Forthcoming). His work on intelligence, deterrence, the Vietnam war and military innovation and strategy has been published in Air Power Journal, Defense Analysis, Intelligence and National Security, National Security Studies Quarterly, International Journal of Intelligence and Counterintelligence, International Security, International Studies Notes, National Security Studies Quarterly, Orbis, Political Science Quarterly, Security Studies, Strategic Review, Studies in Intelligence, The Journal of Strategic Studies and U.S. Naval Institute Proceedings. He teaches courses on nuclear strategy, international relations theory, and intelligence. Professor Wirtz is currently working on a volume exploring the domestic and regional impact of changing the ABM Treaty and U.S. deployment of National Missile Defense.

A native of New Jersey, Professor Wirtz earned his degrees in Political Science from Columbia University (MPhil 1987, PhD 1989), and the University of Delaware (MA 1983, BA 1980). He was a John M. Olin Fellow at the Center for International Affairs, Harvard University.

His is married to the former Janet Ayden of Milburn, New Jersey and they live in Monterey with their two children. 
Sam J. Tangredi

CAPT, U.S. Navy

Senior Military Fellow

Quadrennial Defense Review Working Group

Institute for National Strategic Studies

National Defense University

Ft. McNair, Washington, DC 20319

202-685-2217

tanmedis@ndu.edu

Captain Sam J. Tangredi, USN, has blended operational and academic experience into a unique career. A Surface Warfare officer, he has served in a fast frigate, aircraft carrier, guided-missile destroyer and dock landing ship, culminating in his recent command of USS HARPERS FERRY (LSD-49). A Navy sub-specialist in StrategicPlanning and International Negotiations, and a fully-qualified Joint Specialty Officer, he has served in the Program Budget Analysis Division, J-5, Joint Staff; as Special Assistant and Speechwriter to the Secretary of the Navy; and as Head, Strategy and Concepts Branch (N513), Office of the Chief of Naval Operations. A graduate of the U.S. Naval Academy and distinguished graduate of the Naval Postgraduate School, Captain Tangredi earned a Ph.D. in International Relations from the University of Southern California, and was a national security fellow of the Hoover Institution at Stanford University. He is the author of over seventy articles, book chapters and working papers on defense issues, and recently appeared on The History Channel's The Great Ships series. His latest article, "The Fall \& Rise of Naval Forward Presence," won the 2000 U.S. Naval Institute 'ArleighBurke Prize' as best essay on contemporary naval issues.

The QDR Working Group is a CJCS-chartered study conducted by a small group at National Defense University to identify prospective issues and prepare the Joint Staff and overall Department of Defense for the Quadrennial Defense Review of 2001. 


\section{Air Marshal Sir Timothy Garden KCB MA MPhil FRAeS FRUSI Centre for Defence Studies, King's College London}

Tim Garden was born in 1944 and read Physics at St Catherine's College, Oxford from where he went on to join the Royal Air Force. He trained as a pilot and his operational flying tours have included both tactical and strategic bombers, a period as a flying instructor, and a tour commanding a helicopter base. In mid career he took a postgraduate degree in International Relations at Magdalene College, Cambridge before becoming the Director of Defence Studies for the Royal Air Force.

Between 1987 and 1994, he served continuously in the Ministry of Defence both on the central and air staffs. His appointments included a period on the Air Force Board as Assistant Chief of the Air Staff. He was subsequently the Assistant Chief of the Defence Staff responsible for planning the long term defence programme for all 3 Services. In 1994, on promotion to air marshal, he was appointed as the Commandant of the Royal College of Defence Studies. After retiring from the military, he was Director of the Royal Institute of International Affairs at Chatham House until mid 1998. He now writes and broadcasts on foreign and security policy issues, and is the chief editor of The Source internet public sector journal . His many publications include: Can Deterrence Last?, in which he looks at comparative nuclear strategies of nations; and The Technology Trap, in which he examines the problems of high cost military technology. He is currently at the Centre for Defence Studies, Kings College, London and is leading a research project on European defence capabilities; and he remains an Associate Fellow for the International Security programme at Chatham House. This year'he has been carrying out UK Government sponsored work in support of the Palestinian Authority for their negotiations with Israel.

He is an Honorary Fellow of St Catherine's College, Oxford, a Fellow and Council member of the Royal Aeronautical Society and a Fellow and former Council member of the Royal United Services Institute for Defence Studies. He is also a member of advisory boards to the NATO Defense College in Rome, the Centre for Strategic Studies at the University of Hull, Lancaster \& York Universities' Defence Research Institute, DERA Analysis Board and to the Centre for International Studies at Cambridge University. He was a member of the UK government panel of experts for the 1998 strategic defence review. He was awarded the CB in 1992 and his knighthood in 1994. 


\section{Eliot A. Cohen}

Current as of 23 July 2000

Eliot A. Cohen is professor of strategic studies at the Paul H. Nitze School of Advanced International Studies (SAIS) of the Johns Hopkins University. He is the founding Director of the Center for Strategic Education, a curriculum development and university teacher training program.

He graduated Harvard College in 1977 magna cum laude in government and received his Ph.D. there in the same subject in 1982. From 1982 to 1985 he was Assistant Professor of Government at Harvard and Assistant Dean of Harvard College. In 1985 he became a member of the Strategy Department of the United States Naval War College. In February 1990 he joined the Policy Planning Staff of the Office of the Secretary of Defense, where he worked on a range of issues, including force planning and regional conflict, and in July of that year he was appointed to the chair in strategic studies at SAIS. In 1996-97 he was a Fellow at the Woodrow Wilson International Center for Scholars.

Eliot Cohen's most recent monograph, co-authored with Andrew Bacevich and Michael Eisenstadt, is Knives, Tanks, and Missiles: Israel's Security Revolution (Washington Institute for Near East Policy, 1998). In 1991-93 he directed and edited the Gulf War Air Power Survey, which included eleven book-length reports, published by the Government Printing Office in 1993. With Thomas Keaney he has written Revolution in Warfare? Air Power in the Persian Gulf (Naval Institute Press, 1995). With John Gooch, he wrote Military Misfortunes: The Anatomy of Failure in War (Free Press, 1990). His other books are Commandos and Politicians (Harvard University Center for International Affairs, 1978) and Citizens and Soldiers (Cornell University Press, 1985). His current book project, Supreme Command, is a study of civil-military relations in wartime. His articles have appeared in International Security, Foreign Affairs, Studies in Intelligence, Commentary, Military History Quarterly, and Foreign Policy. His shorter articles and reviews have appeared in Marine Corps Gazette, the New York Times, The New Republic, The Wall Street Journal, National Review, and other publications.

He is Contributing Editor at The New Republic and Military Book Review Editor at Foreign Affairs. He is a member of the International Institute for Strategic Studies, the Council on Foreign Relations, and many other professional organizations. He has consulted to various organizations, including the White House, the intelligence community, and Department of Defense, and testifies frequently before congressional committees on a variety of national security-related subjects. In 1982 he was commissioned in the United States Army Reserve and served for several years in reserve status as Military Assistant to the Director of Net Assessment, Office of the Secretary of Defense. For his work as Director of the Gulf War Air Power Survey he received the Air Force's Decorationfor Exceptional Civilian Service. 


\section{Up \\ Aboldt NIPP}

Dr. C. Dale Walton is a specialist in international relations whose Board of Adrisors 1ies the development of the European Union as an international actor,

Publications strategic relationships and security problems in Asia, geopolitics, and US military-strategic history.

Activities

Dr. Walton holds a BA in Political Science, Magna Cum Laude, from the University of New of Mexico (1993), a MS in Defense and Strategic Studies from Southwest Missouri State University (1994), and a Ph.D. from the University of Hull (Ph.D., 1999). He was an Earhart Fellow at

Internships the University of Hull.

NIPP Feedhack

Dr. Walton is currently revising his doctoral thesis, Victoy Denied: The Myth of Inevitable American Defeat in Vietnam , for publication. He has published numerous articles and book reviews in journals including Comparative Strategy , European Security , The Journal of

Search the Site Slavic Military Studies, National Security Studies Quarterly , and Intelligence and National Security .

Before joining the National Institute, Dr. Walton held several positions related to US national security, particularly ballistic missile, defense, and Congressional decision making. Most recently, he provided support to the Decision Strategies Department and the Asia-Pacific Study Group at the US Naval War College. While at the NWC, his work included research and authorship related to the Korean Futures Project. Dr. Walton has also taught at the University of Hull. 


\section{$\underline{\text { Strategy in the Contemporary World }}$}

\section{Introduction}

John Baylis

This book has two main aims. The first is to introduce new students to the study of strategy and the second is to make the case that strategic studies remains a vibrant, intellectually stimulating and relevant subject. Clearly both of these aims are closely interrelated. Implicit in the second aim is the recognition that strategic studies is currently under threat. With the end of the Cold War many felt that strategic studies had finally had its day (Baldwin). It had been one of the dominant sub-fields in the study of international politics from the 1950s to the 1980s, but with easing of East-West tension in the early 1990s it became to be regarded by some as a "Cold War" subject which was no longer relevant to the new development taking place in world politics. The utility of force was seen to be in decline and intellectual attention shifted to new issues associated particularly with the processes of globalization which many believed were transforming the whole basis of international relations. To the extent that conflict remained an area of academic study, the focus was now on "security", broadly defined to take in a range of political, social, economic and environmental, as well as military aspects.

At one level the decline in significance of strategic studies is understandable and perhaps even to be welcomed. In many respects, as a sub-field of international politics, it was too dominant during the Cold War. However, the editors of this volume believe that attempts by some to abolish the subject from the university syllabus is not only premature but unwise. As the various conflicts which have occurred since the end of 
the Cold War testify, the role of forceremains a significant feature of world politics and an understanding of strategy continues to be, not only relevant, but import in any study of international relations.

In order to set the scene for the chapters that follow, this introduction aims to provide answers to three main questions: 1)What is Strategic Studies? 2) What criticisms are made of Strategic Studies and 3) What is the relationship of Strategic Studies to Security Studies?

\section{WHAT IS STRATEGICSTUDIES?}

The definitions of "strategy" contained in Box 1 display some common features but also some apparently significant differences. The definitions by Clauswitz, Von Moltke, Liddell Hart and Beaufre all focus on a fairly narrow definition which relates military force to the objectives of war. This reflects the origins of the word from the ancient Greek term for "generalship". The definitions from Foster and Osgood, however, draw attention to the broader focus on "power", while Murray and Grimslay highlight the dynamic quality of "process" inherent in the formulation of strategy. While the essence of strategy is conveyed in the former definitions, increasingly writers on the subject have emphasized that strategy (particularly in the nuclear age) has a peace time as well as a war time application. It is much wider than simply the study of wars and military campaigns. Thus, the most useful definition of contemporary strategy, therefore, is the application of military power to achieve political objectives, or more specifically "the theory and practice of the use, and threat of use, of organized force for political purposes" (Gray 1999). Broader still is the concept of Grand Strategv which involves 
the coordination and direction of "all the resources of a nation, a band of nations, towards the attainment of the political objectives"sought (Liddell Hart).

\section{Box 1Definitions of Strategy}

"Strategy (is) the use of engagements for the object of war"

Carl von Clausewitz

"Strategy is the practical adaptation of the means placed at a general's disposal to the attainment of the object in War"

\section{Von Moltke}

"Strategy is the art of distributing and applying military means to fulfill the ends

$$
\text { of policy" }
$$

\section{Liddell Hart}

"Strategy is ...the art of the dialectic of force or, more precisely, the art of the dialectic of two opposing wills using force to resolve their dispute".

Andre Beaufre

"Strategy is ultimately about effectively exercising power"

$$
\text { Gregory D Foster }
$$

"Strategy is a plan of action designed in order to achieve some end; a purpose

together with a system of measures for its accomplishment".

$$
\text { J C Wylie }
$$

"Strategy is a process, a constant adaptation to the shifting conditions and circumstances in a world where chance, uncertaintity, and ambiquity dominate".

$$
\text { Murray and Grimslay }
$$

"Strategy must now be understood as nothing less than the overall plan for utilizing the capacity for armed coercion - in conjuction with economic, diplomatic, and psychological instruments of power - to support foreign policy most effectively by overt, covert and tacit means"

\section{Robert Osgood}


Because strategy provides the bridge between military means and political goals, students of strategy require knowledge of both the political process and military operations. As Richard K Betts has argued: "It is impossible to understand impulses and choices in the political dimension of war and peace without understanding constraints and opportunities in the military dimension. This point has also been made in a slightly different way by Henry Kissinger who has argued that 'the separation of strategy and policy can only be achieved to the detriment of both. It causes military power to become identified with the most absolute application of power and it tempts diplomacy into an over-concern with finesse. Since the difficult problems of national policy are in the areas where political, economic, psychological and military factors overlap we should give up the fiction that there is such a thing as "purely military advice",.

It follows from this that strategy has to be studied from an interdisciplinaryperspective. To understand both dimensions of strategy, it is necessary to know something about politics, economics, psychology, sociology and geography, as well as technology, force structure and tactics.

Another aspect of the subject which follows from the definition of strategy as the link between military power and political purpose is that it is essentially a pragmatic and practical activity. This is summed up in Bernard Brodie's comment that "Strategic theory is a theory of action". It is a "how to do it" study, a guide to accomplishing and doing it efficiently. As in many other branches of politics, the question that matters in strategy is: will the idea work? As such, in some ways strategic studies can be seen as "policy relevant". It can be an intellectual aid to official performance. At the same time, however, it can also be pursued as "an idle academic pursuit for its own sake”. Despite 
the criticisms which have been leveled against it (see below) it provides an exacting intellectual training for those who wish to pursue a strategic education.

As a subject of study, however, it is worth noting that strategic studies cannot be regarded as a discipline in its own right. As one of the contributors to this volume has noted elsewhere, it is a subject with a sharp focus - the role of military power - but no clear parameters, and it is parasitic upon arts, sciences and social science subjects for ideas and concepts which its practitioners have developed. (Garnett). Many of those who have made a contribution to the literature on the subject have come from very different fields. Herman Kahn was a physicist, Thomas Schelling was an economist, Albert Wholstetter was a mathematician, Henry Kissinger was a historian and Bernard Brodie was a political scientist.

One of the results of these different academic backgrounds of writers on the subject has been an ongoing debate about methodology - how to study the subject. Bernard Brodie, who more than anyone else helped to establish strategic studies as a subject in the aftermath of the Second World War, initially argued that strategy should be studied "scientifically". He was concerned that strategy was "not receiving the scientific treatment it deserves either in the armed services or, certainly, outside them". Writing in own article in a1949 entitled "Strategy as Science", Brodie called for a methodological approach to the study of strategy similar to the one adopted by economics. Strategy, he argued, should be seen as "an instrumental science for solving practical problems". What he wanted was a much more rigorous, systematic form of analysis compared with the rather superficial narrow approach to security problems adopted by the military, who were preoccupied with tactics and technology. 
As Brodie himself was later to recognize, however, the enthusiasm for science, which himself had helped to promote, meant that strategic studies in the 1950s"developed a scientistic strain and overreached itself". By the 1960's Brodie was calling for a "midcourse correction". The conceptualization of strategy using economic models and theories had been taken further than he had expected. Brodie was concerned about the "astonishing lack of political sense" and the "ignorance of diplomatic and military history" that seemed to be evident amongst those writing on the subject. Significantly, Brodie's worries were heeded and from the 1970s onwards when there was a leavening of the scientismby better comparative historical analysis.

Apart this problem of methodology and the debate about science the academic approach to the subject also raised concerns about the neglect of operational military issues. For Brodie (echoing Clemenceau) strategy was too serious a business to be left to the generals. As strategic studies developed from the late 1940s onwards civilian analysts came to dominate the field. By the 1980s, however, there was a growing feeling that many of the civilian strategists in their university departments and academic "think tanks" were leaving out the essential understanding of matters military in their analyses and theorizing. For a new breed of strategists at the time operational issues had to be brought back in. Military science had become the "missing discipline". Writing in 1996 Richard K Betts argued that: "if strategy is to integrate policy and operations, it must be devised not just by politically sensitive soldiersbut by military sensitive civilians". Just as Brodie had been Concerned about the overly narrow approach of the military in 1949, so Betts was concerned that the pendulum had swung too far in the opposite direction. Civilian strategists were neglecting the military side of strategy. 
This concern with operational issues helped to revive an interest amongst strategists with the different "elements" or "dimensions" of strategy. In his study "On War" Clausewitz argued that "everything in strategy is very simple, but that does not mean that everything is very easy". Reflecting this sentiment, Clausewitz himself pointed out that strategy consisted of moral, physical, mathematical, geographical and statistical elements. Michael Howard, in a similar vein, refers to the social, logistical, operational and technological dimensions of strategy. This notion of strategy consisting of a broad, complex, pervasive and interpenetrating set of dimensions is also taken further in Colin Gray's recent study of Modern Strategy. Gray identifies three main categories ("People and Politics"; "Preparation for War"; and "War Proper") and seventeen separate dimensions of strategy. Under the "People and Politics" heading he focuses on people, society, culture, politics and ethics. "Preparations for War" includes economics and logistics, organization, military administration, information and intelligence, strategic theory and doctrine, and technology. The dimensions of "War Proper" consists of military operations, command, geography, friction, the adversary and time. Echoing Clausewitz, Gray argues that the study of strategy is "seriously incomplete" if it is considered in the absence of any one of these (interrelated)dimensions.

\section{$\underline{\text { Strategic Studies and the Classical Realist Tradition }}$}

Apart from understanding the complexities of strategy, it is important to understand the philosophical underpinnings or assumptions of those who write about the subject. According to J C Garnett "despite differences of interpretation and emphasis... it is fair to say that most contemporary strategists in the Western World belong, in an important 
sense, to the same intellectual tradition. Their minds are tuned to the same wavelengths; they share a common set of assumptions about the nature of international political life, and the kind of reasoning which is appropriate to handling politicalmilitary problems". In general, this seems to be just as true today, as in the mid 1970's when Garnett made the point. "Realism", as a theory of political behaviour, remains pervasive in contemporary strategic writings (even though it holds a much less dominant position in the literature on international relations as whole).

Although there are differences between "Realists", there are certain views and assumptions that most would agree upon. These can be best illustrated under the following headings:

- Humannature

- Anarchy and Power

- International Law, Morality and Institutions

\section{Fiman Nature}

Most realists are very pessimistic about human nature. Reflecting the views of philosophers like Thomas Hobbes, men are seen as "inherently destructive, selfish, competitive and aggressive". Hobbes accepted that human beings are capable of generosity, kindness and cooperation but the pride and egoism which is inherent in human nature means that mankind is also prone to conflict, violence and great evil. For realist writers one of the great tragedies of the human condition is that these destructive traits can never be irradicated. Reflecting this view, Herbert Butterfield argued that "'behind the great conflicts of mankind is a terrible human predicament which lies at the heart of the story". 


\section{$\underline{\text { Anarchy and Power }}$}

Based on this rather dark view of the human condition, realists tend to view international relations in similar pessimistic terms. Conflict and war are seen as endemic in the international system and the future is likely to be much like the past. Just as individuals seek their own interests, so states (which realists focus their attention upon) are also engaged in a relentless competitive struggle. Unlike the way that conflicts are dealt with in domestic society, however, through the role of authoritative government, the clash between states are much more difficult to resolve. In the absence of world government, realists argue that states have to adopt a "self-help" approach to their interests and especially their security. Who wins in the constant struggles which take place is not who is right but, as Thycidides demonstrated in his account of The Pelopponesian Wars, who is most powerful. This stress on the central role of power in international relations is aptly summed up in Hobbes's description of the human condition as " a restless struggle for power which ceases only in death"

Realists, therefore, tend to stress what they see as the harsh realities of world politics and are somewhat contemptuous of Kantian approaches which highlight the opportunities for "permanent peace". As Gordon Harland has argued: "Realism is a clear recognition of the limits of reason in politics: the acceptance of the fact that political realities are power realities and that power must be countered with power; that self-interest is the primary datum in the action of all groups and nations. In an anarchical system power is the only currency which matters when security interests are threatened. 


\section{$\underline{\text { International Law, Moralitv and Institutions }}$}

Given this "realpolitik" view of world policies, it is not surprising that that realists see a limited role, not only for "reason", but also for law, morality and institutions. In a domestic context, law can be an effective way for societies to deal with competing selfish interests. In an international system without effective government, states will agree to laws when it suits them, but will disregard them when their interests are threatened. When states want to break the rules, there is very little to stop them ultimately from doing it - apart from countervailing force.

Similarly, realists do not believe that moral issues can significantly constrain the behaviour of states. Some realists (although not all) believe that very little attention should be given to moralizing about the state of world politics. They point to the absence of a universal moral code and more particularly to the disregard of constraining moral principles by states when they believe their vital interests are under threat. This is not to argue that realists are wholly insensitive to moral questions (see the section on "The Critics of Strategic Studies"). Indeed, many of them, like Niebuhr and Morgenthau agonized about the human condition. However, most realist writers are concerned to try and explain the way the world really is, rather than how it ought to be. Realists believe that their task is mainly to describerather than prescribe.

Realist view International institutions in much the same light as they view law and morality. Just as law and morality are unable to constraint state behaviour significantly when interests are threatened, so international institutions can only play a limited role in preventing conflict. Realists do not dismiss the opportunities for greater cooperation which institutions can create. However, they see these institutions as being set up by 
states to serve their national interests. As long as they do this, the member states will support the institution, but when support for the institution threatens their interests, especially in the security sphere, they tend to abandon them. Realists point, in particular, to the fate of the League of Nations in the inter-war period and the limitations of the United Nations during the Cold War and the Organization for Security and Cooperation in Europe in alleviating conflicts which occurred.

\section{WHAT CRITICISMS ARE MADE OF STRATEGIC STUDIES?}

Although the shared philosophical underpinnings of strategists have helped to give the subject intellectual coherence, many of the realist assumptions have been subjected to fierce criticisms. These criticisms have been discussed in detail elsewhere (Gray 1982), but the following brief discussion gives a flavour of the concern expressed by the opponents of strategic studies. Strategists are said to be:

- Obsessed with conflict and force

- Insufficiently concerned with ethical issues

- Not scholarly in their approach

- Part of the problem, not the solution

- State-centric

Many critics argue that because the main focus of the subject is on the role of military power, strategists tend to be preoccupied by violence and war. Because their view of the world is conflict-oriented they tend to ignore the more co-operative, peaceful aspects of world politics. This leads critics to claim that strategists have a distorted, rather than realistic, view of the way the world is. Some critics even suggest that 
strategists are fascinated by violence, and even take grim satisfaction in describing the darker side of the human condition.

For their part, strategists accept that they are interested in (but not obsessed by) violence and conflict. In their own defence, however, they point out that just as a doctor of heart-disease does not claim to deal with all aspects of health, so they do not claim to be studying every aspect of international relations. They, therefore reject the view that they have a distorted, unrealistic, view of the world, and that they are fascinated, in an "unhealthy" sense by violence.

The claim to moral neutrality, sometimes made by strategists, is another area of criticism. Strategists are seen to be "clinical", cool and unemotional" in the way they approach the study of war, despite the fact that, in the nuclear age, millions of lives are at risk in the calculations that take place about strategic policies. Emphasising the moral outrage felt by some, J R Newman described Herman Kahn's book, On Thermonuclear War, as "a moral tract on mass murder, how to comment it, how to get away with it, how to justify it". Philip Green, in his study of Deadlv Logic, also accused strategists who wrote about nuclear deterrence as being "egregiously guilty of avoiding the moral issue altogether, or misrepresenting $i t^{\prime \prime}$.

Although many strategists have justified the moral neutrality of their approach in terms of scholarly detachment, it is fair to say that some have been sensitive to this criticism. As a result, a number of studies of ethical issues have been written. These include Joseph Nye's book on Nuclear Ethics, Michael Walzer's Just and Uniust Wars and Steven P Lee's study of Morality. Prudence and Nuclear Weapons. These book (together with the moral critical studies by writers like Green) now form an important part of the literature on strategic studies. 
Another important criticism levelled against strategic studies is that it represents "a fundamental challenge to the values of liberal, humane scholarship, that define a University". The implication is that it is not a scholarly subject and should not be taught at University. This criticism has a number of related parts. Firstly, according to Philip Green, it is pseudo-scientific, using apparent scientific method to give it a spurious air of legitimacy. Secondly, because strategists often advise governments on a paid basis they are operating "in a manner incompatible with the integrity of scholarship". E P Thornton described the cosy relationship between strategists and government officials as "suspect, corrupt and at enmity with the universal principles of humane scholarship". And, thirdly, there have also been criticisms that strategists not only provide advice to governments, but they are also involved in policy advocacy which is not part of scholarship.

With a qualification on the issue of policy advocacy, strategists reject the view that their's is not a valid university subject. (See Box 2). They argue that the study of war and peace are issues of profound importance which can, and should be studied in a scholarly way. It is true that there have been attempts at developing a "Scientific" approach to the strategy (and some writers might have taken this too far) but the debate about methodology is not confirmed to strategic studies. The nature of "science" in a social science context remains a lively, ongoing debate.

In general, strategists recognize the dangers of developing too cosy a relationship with officials when they advise governments on a paid basis. Like many other experts in their field, (eg. economists) however, they see no necessary inconsistency between scholarship and advice. Being a practical subject there are some benefits from analyzing strategic issues at close hand, providing that a "detached" approach is adopted. Policy 
advocacy, however, is a different matter. Some strategists do drift into the realm of advocating certain policies, but when they do so they are wearing their "concerned citizens" hat rather than acting in an academic capacity. 


\section{Box 2}

\section{Strategic Studies as a Universitv Subiect}

"The study of strategy in Universities may be defended on several different, yet complementary, grounds. In strictly academic terms, the subject poses sufficient intellectual challenge as to merit inclusion in, or even as, a course of study fully adequate to stretch mental resources. In, and of itself, that argument is sufficient to justify the inclusion of strategic studies in University curricula, but one can, and should, proceed to argue that the study of strategy is socially uselful.... Many views are defensible concerning the proper and appropriate duties of a university. This author chooses a liberal, permissive perspective. He sees value in a field of study that seeks truth and may have relevance to contemporary policy and, as a consequence, may contribute to the general well-being".

\section{S Gray}

"In strategic studies the ability to argue logically and to follow a piece of strategic reasoning is very important, but even more important is the elusive, almost indefinable quality of political judgement which enables a man to evaluate a piece of analysis and locate it in a wider political framework".

J C Garnett

Another forceful criticism of strategic studies is that it is part of the problem, not the solution'. What opponents mean by this is that the Clausewitzean perspective of strategists which sees military power as a legitimate instrument of policy, helps to perpetuate a particular mindset amongst statesmen and their publics which encourages the use of force. It is this realist thinking, critics argue, which lay behind the development of theories of deterrence, limited war, and crisis management which were so dangerous during the Cold War. Anatol Rapoport is one writer who charges strategists with a direct responsibility for promoting a framework of thinking about security which is largely hostile to what he regards as the proper solution, namely disarmament. In a stinging attack he argues that "the most formidable obstacles to 
disarmament are created by the strategists who place their strategic considerations above the needs of humanity as a whole, and who create or help maintain an intellectual climate in which disarmament appears to be unrealistic".

Linked to this criticism is the view that because strategists are so pessimistic about human nature and the chances of significant improvements in the conduct of international politics, they ignore the opportunities which exist for peaceful change. To see the past as a history of constant conflict and to suggest that the future will be the same is to help create a fatalisticimpression that plans for human progress will always fail. More than this, by emphasizing mistrust, self-helpand the importance of military power in an anarchic international system, is self-fulfilling. Given this "socially constructed" view of the world, it is not surprising that states will constantly find themselves in conflict with each other.

Once again, strategists vigorously contest these criticisms. They argue that their ideas reflect (rather than create) the "reality" of world politics. The fact that most statesmen in positions of responsibility tend to share their "realist" assumptions is not due to an intellectual climate "socially constructed"by academic strategists but the result of their own experiences as well as their individual understanding of history. The notion that strategic studies as a subject is "a monstrous crime committed by self-interested strategists against the general public" is seen as absurd. Academic strategists may occasionally act as policy advisers but their influence over government decision-making has been much less than such critics suggest.

On the question of "peaceful change", strategists do not dismiss the fact there are periodically opportunities for periods of peaceful coexistence. They are, however, very skeptical (to say the least) about the prospects for "perpetual peace" or a radical 
transformation of the whole basis of world politics. Conflict, they believe can be mitigated (in part through effective strategy), but it is highly unlikely that it can be transcended completely. In such a context it is impossible to abolish the need for strategic studies.

The emphasis on state's pursuing effectivestrategies (which take account of the realities of power) provides the basis for another criticism of strategists. This centers on the state-centric approach, which, it is argued, pervades strategic studies. According to this critique, strategists are so preoccupied by threats to the interests of states that they ignore security issues within the state. Many critical security theorists argue that the state is not the most appropriate referent for studying security. Rather, attention should be focused on the individual whose security is often threatened, rather than protected by the state. Other writers, who perceive the growing erosion of the state prefer to focus on "societal security" or even "global security" issues.

Strategists would argue that while there has been a tendency to stress the role of the state, it is wholly untrue that they have neglected intra-state conflict. Clausewitz himself dealt with peoples wars and a considerable part of the strategic studies literature deals with revolutionary warfare. As wars of national disintegration (Bosnia, Kosovo, Chechnya) have become more prevalent in the post-cold war era, more attention has also been given in the literature to these kind of conflicts. Despite this, strategists continue to argue that even with all the contemporary challenges to the modern state, it continues to be the major actor in world politics. Strategists therefore, offer no apologies for their continuing interest in the issues relating to state security. 


\section{WHAT IS THE RELATIONSHIP BETWEEN STRATEGIC STUDIES AND}

\section{SECURITY STUDIES?}

One of the main challenges to strategic studies since the end of the Cold War has come from those who argue that attention should be shiftedaway from the study of strategy to the study of security. According to this view "security", defined in terms of freedom from threats to core values", is a more appropriate concept for analysis in the contemporary world. The problem with strategy, it is argued, is that it is too narrow and increasingly less relevant at a time when major wars are declining, whereas threats to political, economic, social and environmental security interests are increasing. Defined more broadly, security, therefore, is seen, by some, to be of more valuable as an organizing framework for understanding the more complex, multi-dimensional risks of today. (See Buzan).

Faced with this challenge, Richard K Betts, writing in 1996 asked the question "Should strategic studies survive?!" Betts conceded that security studies in the United States has been squeezing strategic studies out of the University curriculum. He is not opposed to security studies, but he makes two very important points. Firstly, it is appropriate to distinguish between "strategy" and "security" studies in order to recognize that "security" includes a wide range of topics, "as long as no doubt is left that security policy requires careful attention to war and strategy". In other words, military power remains a crucial part of security. And secondly, he argues that "expansive definitions of security quickly become synonymous with "interest" and "well-being", do not exclude anything in international relations or foreign policy, and this becomes indistinguishable from those fields or other sub-fields". 
The editors of this book accept the value of security studies while at the same time sharing these concerns about the coherence of the field. More importantly, however, we believe that "strategy" remains a distinctive and valuable area of academic study. Strategy is part of security studies, just as security studies is part of International Relations, which itself is part of Political Science. This can be expressed diagrammaticallyin the following way:

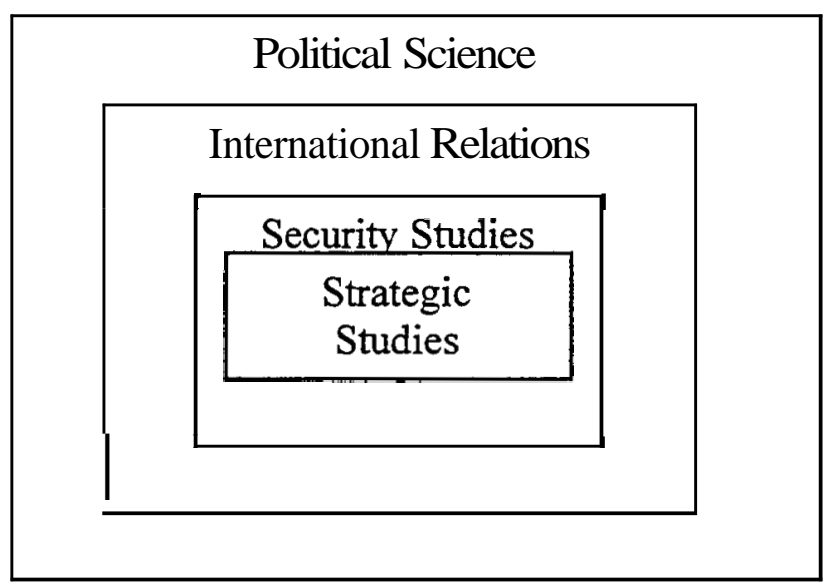

Despite all of the changes which have occurred in world politics since the late 1980s there is in many respects an underlying continuity with earlier eras. The euphoria that a fundamental transformation of international relations was underway, has proved to be ill-founded. As we have seen from the Gulf War, Bosnia, Kosovo and Chechnya (and many other conflicts) force and military power continue to be an important currency in the international system at the beginning of the twenty first century. Certainly important changes are taking place in world politics, associated with the twin forces of globalization and fragmentation, and wars between the great powers, for the moment at least, have slipped into the background. The sad fact remains, however, that the 
utilization of military power as an instrument of political purpose and therefore, strategic studies, remains just a relevant today as it has been in the past.

To reflect the continuing importance and vitality of the subject this book is organized into three main sections... 


\title{
CHAPTER 2
}

\section{FORCE AND MORALITY}

\author{
H. McCoubrey
}

The idea of ethical constraint upon the waging of war and its embodiment in legal norms is of ancient origin but still seems profoundly paradoxical. War, as an ultimate collapse of 'normal' international relations, appears to be a situation in which the most ruthless use of force must prevail and in which ethical constraint can serve only as a potentially fatal self-inflicted impediment to effective action. If it was indeed the purpose of ethical and legal norms to obstruct and diminish the combat efficacy of fighting forces, such strictures would be fully justified and norms so conceived could not long endure. That, however, is neither their purpose nor their effect. The real foundation of ethical and legal constraint upon warfare can be found clearly stated in a much misrepresented passage in Carl von Clausewitz' classic work Vom Kriege, published posthumously in 1832. The great Prussian theorist wrote that,

He who uses force unsparingly, without reference to the bloodshed involved, must obtain a superiority if his adversary uses less vigour in its application ... . From the social condition both of States in themselves and in their relations to each other ... War arises, and by it War is ... controlled and modified. But these things do not belong to War itself, they are only given conditions; and to introduce into the philosophy of War itself a principle of moderation would be an absurdity.' 
If war is analysed as a phenomenon in isolation a logic of illimitable force might indeed seem to be suggested. However, as Clausewitz indicates, wars and armed conflicts $^{2}$ do not thus arise in isolation but occur in the real context of international relations, which imports expectations which not only condition reactions to armed conflict but themselves have real political and military effect.

In the first place needless barbarity renders both the conduct and the ultimate resolution - the desired 'end state'- of conflict more difficult than it otherwise might be. As the late Colonel Klaus Kuhn commented,

the quickest way of achieving and maintaining a lasting peace is to conduct hostilities humanely .... It is evident that humanitarian considerations cannot be dissociated from the strategic concept of military leaders?

The proscription of unnecessary barbarity is counselled not only by ethical and humanitarian considerations but also by reference to the response of other States to a belligerent Power and the inevitable tendency to a prolongation of conflict where fear of probable mistreatment renders a cornered enemy desperate. The idea is not new, it was asserted in the 5th Century BC by the Chinese tactician Sun Tzu in advising commanders 'Do not press a desperate foe too hard' ${ }^{4}$ There is ample historical evidence to support the contention. In 1945 the forces of the Third Reich sought to resist the advancing Soviet army, whose fury was at least in part occasioned by prior German conduct, long after it was clear that all hope of success was gone, even as vast numbers hastened to surrender to the Allies in the west. In view of the ruthlessness and boundless contempt for all norms of constraint manifested by the Nazis themselves, it is pertinent to point out that the projected '1000 year Reich' actually endured for less than twelve years. Upon a much lesser 
scale it may also be noted that in the 1990-91 Gulf Conflict Kuwait did not remain the '19th Province of Iraq' for even one year.

It may be added that, as Colonel Kuhn emphasised, all wars must eventually end - if only through the economic exhaustion of the belligerents - and thereafter peaceful relations must in some form be resumed. This process is, ex hypothesi, never easy and the more brutal the conflict the more difficult post-war reconstruction will be. In strategic planning it is here that the question of the desired 'end state' becomes a matter of paramount importance. It has been suggested elsewhere, in the particular context of peace support operations, ${ }^{5}$ that this is a much more important consideration than an arbitrary 'end date' for operational commitments, not least because premature termination of operations may simply lead to a necessity for re-engagement in the short to medium term.

It is thus contended that there are powerful ethical and practical arguments for norms of constraint in armed conflict. At the same time it must be borne in mind that norms governing the conduct of war, in distinction from those governing resort to armed force, are by their nature no more than mitigatory in effect. If it were to be pretended that either ethics or law could render war as such humane, the 'absurdity' to which Clausewitz referred would rapidly become all too evident. In short, humanitarian legal constraint upon armed conflict operates upon two levels, aiming firstly the to reduce or eliminate the occurrence of war and, where this proves impossible, to mitigate its consequences.. These are, and to maintain their viability must remain, pragmatic objectives rooted in the practical experience of warfare.

\section{The Structure of the International Laws of Armed Conflict}

The two broad functions of the laws of armed conflict are performed respectively by the jus ad bellurn and the jus in bello. The jus ad bellum (lit. the lavi 
towards war) $^{6}$ governs and seeks to avert or limit resort to armed force in the conduct of international relations. The jus in bello (lit. the law in war) governs and seeks to moderate the actual conduct of hostilities. It should be made clear from the outset that that these sectors are distinct in both purpose and implication. The applicability of the jus in bello is not affected by the legitimacy or otherwise of the initial resort to armed force by either of the belligerents, if it were otherwise the door would be opened to a return to the worst excesses not of pre-modern 'just war' concepts as such but to its systematichistoric abuses.

The jus ad bellum is now founded primarily upon the 1928 Pact of Paris and article 2(3)(4) of the UN Charter together with Chapter VII (articles 39-51) of the UN Charter. Under these provision resort to armed force is proscribed as a means of international dispute resolution, leaving as legitimate uses of armed force only action in self-defence against attack or enforcement action under UN Security Council authorisation. It is true that arguments are advanced for further exceptions in relation to 'humanitarian intervention', as was suggested in the 1999 Kosovo crisis, but these contentions are to be viewed with some caution and certainly to be construed very narrowly in the face of the fundamental norm of article 2(4).

Where, despite these restraints, armed conflict breaks out the jus in bello becomes operative. It comprises two broad, and to a significant degree overlapping, subsectors known, respectively, for core groups of treaties as 'Hague' and 'Geneva' law. Hague law deals with methods and means of warfare and Geneva law with protection of the victims of armed conflict. It must, however, be emphasised that this is a distinction of convenience rather than one which is either absolute or inflexible. Both sets of norms rest ultimately upon a proscription of the infliction of (militarily) 'unnecessary suffering' first set out expressly in the 1868 Declaration of St. 
Petersburg and the whole jus in bello provision is today categorised as 'international humanitarian law'.

\section{The Background and Development of the Jus ad bellum}

The development of the jus ad bellum may reasonably be seen as a progressive historic evolution of norms designed to counter escalating threats of destabilising conflict endangering the sustainability of international order. The developmental pattern has been episodic in character, punctuated by occasional violent discontinuities and in this sense might be described as revolutionary rather than evolutionary in nature. However, be that as it may, there has been a discernible continuity of principle in seeking to contain armed conflicts within parameters which are sustainable by existing international society. In this respect international law is much like any other law in so far as-a containment of violent confrontations is one of the basic 'law jobs', to borrow a phrase devised by Karl N. Llewellyn, performed by any legal system? The European medieval scholastic 'just war' concept, with ultimate legal origins in the jus fetiale of the ancient Roman Republic," was developed by such figures as St. Augustine of Hippo, St. Raymond of Penaforte, St. Thomas Aquinas and Johannes Tuetonicus" as a limitation of resort to armed force to certain grave causes, although it swiftly degenerated into a mere excuse for aggression. The scholasticjus ad bellum finally lost what remained of its credibility by the end of the 16th century with the dissolution of the late medieval European political order ultimately in the Thirty Years War. The end of this conflict, with the 1648 Peace of Westphalia, is conventionally, if over-simply, taken to mark the beginning of the early modern era of public international legal development. ${ }^{12}$ The shape of early modern public international law is commonly associated with the work of the Dutch scholar Hugo Grotius and, in the present context, particularly 
with De Jure Belli ac Pacis. This is again a considerable over-simplification, ${ }^{13}$ and Grotius actually built, but did not always improve, upon work done in the previous century by the Spanish School ${ }^{14}$ and by Alberico Gentili at Oxford..$^{15}$ The jus ad bellum of the early modern era, up to 1914 , was little more than a revised 'just war' theory, presented in a legalistic rather than ethical mode of discourse which was better suited to contemporary European the social contractarian ideology.

This early modern system faltered in the Napoleonic era but finally collapsed only with the end of the First World War in 1918. This first 'modern' technological war proved so devastating that it generated the first sustained attempt to develop an effectiveglobal collective security system in the shape of the League of Nations. The failure of the League in the renewed global catastrophe of the Second World War is sometimes assumed to mean that the conceptual foundations and structures of the League doomed it from the outset. This is, however, a flawed judgement. Article 10, 11 and 16 of the League Covenant set out a clear doctrine of collective security in a manner not greatly different from that provided for in the UN Charter, although the mechanisms for implementation were admittedly less well defined. The roots of the failure of the league lay, however, not in its constitution but in a failure of political will. Quite apart from the loss of US backing following the political eclipse of President Wilson in 1921, the major Powers amongst the League Members displayed a fatal lack of resolve in facing the aggressive totalitarian regimes of the 1930s to the point at which any reliance upon collective security collapsed and the drift toward renewed global war became irreversible. The League failed, in short, not because it could not work but because it was not made to do so.

One basic principle was, however, established, not by the League Covenant but by the 1928Pact of Paris ${ }^{16}$ which provides by article 1that, 
The High Contracting Parties solemnly declare ... that they condemn recourse to war for the solution of international controversies, and renounce it as an instrument of national policy in their relations with one another.

This basic principle attracted widespread formal acceptance and although comprehensively violated in the 1930s it was accepted as a fundamental norm of public international law in the drafting of the Charters of the International Military Tribunals at Nuremberg and Tokyo which included 'crimes against peace' in their jurisdiction at the trials of the major Axis war criminals.

This principle is today affirmed unequivocally in article 2(3)(4) of the UN Charter which provide that,

(3) All Members shall settle their international disputes by peaceful means in such a manner that international peace and security, and justice, are not endangered.

(4) All Members shall refrain in their international relations from the threat or use of force against the territorial integrity or political independence of any State, or in any other manner inconsistent with the Purposes of the United Nations.

This established the fundamental point that armed force is not a legitimate mode of international dispute resolution and, by the same token, that armed conflict is no longer a lawful condition of international relations. Thus in 1990 whatever the merits, if any, of Iraq's oil claims against Kuwait may have been, ${ }^{17}$ the invasion and occupation was unequivocally a violation of internationallaw

The basic proscription set out by article 2(4) is qualified by two essential exceptions. These are (i) the inherent right of individual and collective self-defencein the face of armed attack preserved by article 51 of the UN Charter and (ii) action for the maintenance or restoration of international peace and security authorised by the UN Security Council under article 42. These provisions are, for the present purpose, 
the key elements of the UN provision for collective security and defence set out by Chapters VII and VIII of the Charter.

The primary provision for the maintenance of international peace and security is made by Chapter VII, comprising articles 39-51. Where a threat to or violation of the peace is anticipated or claimed to have occurred article 39 requires the Security Council to determine whether this is in fact the case. There are some grey areas here and just what constitutes a 'threat to the peace' was at one time a subject for debate." Originally there can be little doubt that the concept was limited to international, i.e. inter-State, aggression but later practice suggests that some internal use of force might fall within this category, at least where it threatens regional destabilisation, as for example in Kosovo in $1999 .{ }^{19}$ N.D. White suggests usefully that,

the situations have at their core the use of armed force, either internal or international. The integrity of the concept has been maintained by many of the recent uses of the terms by the Security Council, covering issues such as threats of force (provocative action directed by Iraq against Kuwait), widespread violations of international humanitarian law (including 'ethnic cleansing' in Bosnia), massive humanitarian crises (caused by the genocide in Rwanda in 1994 which led to related problems in Burundi and Zaire in 1996), and breach of a Security Council arms embargo (relating to Rwanda). ${ }^{20}$

If the Security Council does find a threat to or breach of the peace to have occurred it may under article 40 determine upon 'provisional measures' for the aversion of any escalation of the crisis. Where necessary the Council may impose non-military (primarily economic) sanctions under article 41 or military measures under article 42. Article 42 provides that.

Should the Security Council consider that the measures provided for in Article $\mathbf{4 1}$ would prove inadequate or have proved to be inadequate, it may take such action by air, sea, or land forces as may be necessary to maintain or restore international peace and security. ... 
It must here be emphasised that articles 41 and 42 should not be understood as mandatorily sequential. It is entirely lawful in appropriate cases to proceed straight from article 39 to article 42 , as is made clear by the provision of article 42 that it may be applied if the Council considers that article 41 sanctions 'would prove inadequate' (emphasis added). It may be added that any assumption that economic measures are necessarily the more 'humane' approach has been severely undermined by the experience of the post-1991 sanctions against Iraq. ${ }^{21}$ The point remains significant even when allowance has been made for the fact that the sufferings of the Iraqi people in this context were to a large degree the fault of the Baghdad regime although, in this as in other matters, it proved adept at manipulating the western media. Military sanctions under article 42 were intended to be implemented by UN Forces drawn from, units held in readiness for such service by Member States under obligations assumed under article 43 of the Charter, along with air forces held under article 45 in immediate readiness for 'urgent ... enforcement action'. To provide strategic, but not tactical, direction for these Forces the UN Military Staff Committee was set up under article 47 of the Charter. In practice no article 43 and 45 Forces were thus held in readiness and although the UN Military Staff Committee was set up, its functions are necessarily limited to the advisory function provided for in article $47(1) .{ }^{22}$ It may in practice be said, perhaps a little harshly but nonetheless in essence truly, that the UN Military Staff Committee has become a general staff without ant army.

This original UN peace support vision was effectively derailed by the collapse after 1945 of the wartime inter-Allied consensus - which was in any event never so extensive as some appear to have believed - and its succession by Cold War tensions and the suspicions of the smaller Powers as to the uses to which a Great Power 
dominated Security Council might put readily available forces. It has been questioned whether in the absence of article 43 Forces the Security Council can 'take [military] action' at all. This would, however, seem to be an excessively legalistic interpretation. UN 'Blue Helmet' Forces are necessarily provided by Member States, whether in theory pursuant to an article 43 obligation or, in practice, upon a voluntary ad hoc basis. ${ }^{23}$ In this, as in a number of other respects, the application of the Charter provisions has been adapted to meet the practical exigencies of the circumstances in which it is called to function and this is indeed a vital factor in its effective continuance.

The UN collective security system has never in fact functioned in quite the manner apparently intended by its drafters. The Cold War led to the development of a de facto mixed collective security and balance of (Super)power system. The Permanent Members' veto in the Security Council - which was not a Cold war aberration but, as Cordell Hull maintained, ${ }^{24}$ a sine qua non for major Power acceptance and backing of the Council - ensured that this would be the case. Conflicts in which the Cold War Superpowers either had or perceived themselves to have a major interest were by this means effectively removed from the Security Council's remit. It was thus that so grave an international crisis as the Vietnam War was effectively excluded from the Security Council's agenda. This mixed system endured to the end of the Cold War in the 1980s and served in part to mask a basic problem of structure and resourcing at the heart of the UN system in the absence of an effective implementation of articles $\mathbf{4 3}$ and 45 of the Charter.

UN 'Blue Helmet' Forces have a substantial record of peace-keeping properly so-called, that is to say policing the implementation of a peace settlement. Peace enforcement operations, the restoration of security in a situation in which there is no 'peace' to 'keep', have proved much more problematic. There are two essential 
reasons for this, first the nature of the Forces themselves and secondly the nature of UN crisis management. As to the first, ad hoc multi-national forces created at short notice are inevitably prey to problems of command, control and interpretability, including the position of Force Commanders who must in effect negotiate the implementation of their orders with national contingent commanders in a manner unthinkable in almost any other military hierarchy. These inherent problems are compounded by the tendency of the UN Organisation to engage in inappropriate micro-management of 'Blue Helmet' operations. The consequences were seen in the fate of UNPROFOR in former-Yugoslavia in the 1990s. The Force was under resourced, beset by command and control problems and burdened by ever-shifting and in some cases actually contradictory mandates. In this context it was less surprising that it faced grave difficulties in its operations than that it succeeded in holding a near impossible situation until the Dayton Peace Accords were in place. Paradoxically, having deployed a 'peace-keeping' force in advance of the peace settlement, the UN then, post-Dayton, put in the much more robust NATO-led IFOR and SFOR Forces in effect in enforcement roles.

With the end of the Cold War and the collapse of the former-USSR the post-1945 mixed collective security/balance of power dissolved with a consequent massive increase in the peace-support demands placed upon the UN which the organisation lacked the capacity to sustain. The difficulties experienced by UNPROFOR in former Yugoslavia, UNOSOM and UNITAF ${ }^{25}$ in Somalia and the overwhelming disaster in the African Great Lakes region combined to demonstrate the need for a revised basis for effective peace support in the new era.

The favoured option, most clearly set out in Boutros Boutros-Ghali's Supplement to Agendafor Peace, ${ }^{26}$ has been resort to regional organisations and arrangements. The immediate examples of this were seen in the NATO-led Forces in the successive 
crises in former-Yugoslavia in the 1990s, IFOR, SFOR and KFOR. This regional approach is not as such legally innovatory and is in fact expressly provided for by Chapter VIII of the UN Charter. Article 53 actually requires the Security Council to make use of regional organisations in peace support action 'where appropriate'. This latter caveat is of course the central issue. At the outset of the UN era, at the Dumbarton Oaks and San Francisco meetings, there was intense debate upon the relative merits of globalism and regionalism in security structures. Ultimately the globalist perception was maintained but an important, although subordinate, role was admitted for regional organisations with the aim of enhancing the resources available for peace maintenance and enforcement whilst guarding against the self-evident danger of regional hegemonism. The resource-driven crisis in post-Cold War peace support has revived interest in the Chapter VIII mechanism and this will no doubt be an important element in the emerging 21st century global (and regional) peace support architecture. ${ }^{27}$ It must, however, also be accepted that the very diversity of the character, objectives and capacities of the various organisations preclude this from approach from affording any simple or singular solution to global security problems. It is more the case that a range of options are offered which may in appropriate cases greatly enhance the peace support options which may be available at need.

\section{The Background and Development of the Humanitarian Jus in Bello}

Attempts to mitigate the conduct of warfare through regulatory norms have a long, if rather variable history. ${ }^{28}$ The earliest surviving proscription, the ban upon 'poison weapons', originated in the Graeco-Roman era, but most current regulations are, by the nature of their subject matter, of much more recent origin. The emphasis of medieval thought upon the law and ethics of warfare was directed 
overwhelmingly to the jus ad bellum rather than to the jus in bello and, despite the counsel towards moderation offered by St. Augustine of Hippo, ${ }^{29}$ the implication of 'just war' theory that at least one side must be presumed to be acting 'unjustly' tended to discount humanitarianism in politically convenient practice. That this occasioned doubts cannot be denied, evidence is found in occasional Papal Interdicts following particularly brutal campaign $\mathrm{s}^{30}$ and the disquiet expressed after the massacre of prisoners at Agincourt in 1415 . The nearest the middle ages came to a genuine jus in bello was the jus armorum (law of arms) ${ }^{31}$ which related more to chivalric fantasies than practical humanitarianism. There were even, unsuccessful, attempts at arms control in the period, for example the endeavour of the Second Lateran Council to ban the use of cross bows and arbalests. The early modern era of international law, after 1648, saw at the outset an era of limited dynastic and territorial wars between States which few ideological differences. In this context there developed what Jean Pictet has termed, with perhaps some exaggeration, a 'customary humanitarian law' of armed conflict." This, however, was destroyed by the scale and bitterness of the French Revolutionary and Napoleonic Wars at the turn of the 18th and 19th centuries. A nadir was reached in the middle of the 19th century with the 1855-6Crimean War and the 1859 Franco-Austrian and it was from these experiences that the modern international humanitarian laws of armed conflict developed.

Modern international humanitarian law originated on the battlefield of Solferinoin the Franco-Austrian War of 1859. A Swiss businessman, Henry Dunant, passing by shortly after the battle, arranged and financed medical rescue action by which many lives were saved and, significantly, did so impartially for French and Austrians alike although his own sympathies were markedly pro-French. Subsequently he published a pamphlet, Souvenir de Solferino (A Memory of 
Solferino) ${ }_{1}^{33}$ in which he advocated (i)the conclusion of a treaty for the protection of the wounded and sick in land warfare and (ii) the creation of an international organisation to supplement and assist the military medical services in time of war. These proposals came to fruition, respectively in the first, 1864, Geneva Convention for the protection of the wounded and sick and in the creation of the International Red Cross Organisation. Modern 'Geneva' law is found primarily in the four 1949 Geneva Conventions. These make provision, respectively, for the wounded and sick on land, the wounded, sick and shipwrecked at sea, prisoners of war and civilians. These treaties are nearly universally ratified and their essential provisions can now claim the status of customary international law and as such are binding upon all States, whether or not they are formally Parties to the Conventions. Further provision for international armed conflict is made by 1977 Additional Protocol I which to a large extent simply elaborates existing principles, but it also makes further provision some of which has proved highly controversial and although the number of ratification's is increasing it cannot as yet (2000) be considered to have achieved customary status. ${ }^{34}$

For a variety of reasons, political and legal, the establishment of humanitarian norms in non-international armed conflicts, 'civil wars', has proved even more difficult than that of the equivalent provisions for international conflicts - even though the Lieber Code established by the Union side in the American Civil War was one of the early benchmarks in humanitarian legal development. Modern provision amounts to a reduced version of the provision for international conflicts and is found in article 3 common to the 1949 Geneva Conventions and 1977 Additional Protocol II thereto.

'Hague' law took on its modern shape at roughly the same time as 'Geneva' law, although some of its provisions are amongst the oldest norms of public 
international law. The foundational treaty for modern purposes is an arms control measure, the 1868Declaration of St. Petersburg. In its Preamble it set out the basic Doctrine of 'Unnecessary Suffering'. This principle underpins the whole of modern international humanitarian law, emphasising the aversion of militarily unnecessary severity both in the adoption of methods and means of warfare and the protection of victims of armed conflict.

Protection of the Wounded, Sick and Shipwrecked

Modem provision for the protection of the wounded, sick and shipwrecked is now found principally in 1949 Geneva Conventions I and II, dealing respectively with conflict on land and at sea, with supplementary provision made by 1977 Additional Protocol I. The norms are essentially the same on land and at sea, subject to the obvious differences between the terrestrial and maritime media. The key principle is set out by article 12 which is in effect common to 1949 Geneva Conventions I and 11. It requires that the wounded and sick must be treated humanely and cared for according to their needs, with prioritisation in order of treatment determined solely by reference to medical need and not according to nationality, rank, gender, politics, religion or any other medically irrelevant factors. This basic principle is repeated and amplified in detailed by article 10(2) of 1977 Additional Protocol I.

As an obvious prerequisite for effective medical care all possible measures are required to be taken to search for and collect the wounded, sick and/or shipwrecked after military and naval engagements. ${ }^{35}$ This immediately raises the difficult question of the interface between humanitarianism and necessity, there can be no duty to put a unit at unreasonable risk of its own destruction in conducting rescue work. The point can most plainly be illustrated by reference to naval warfare. Thus, H.M. Ships Dorsetshire and Maori after the sinking of K.M. Bismark in the Second World War 
were entitled to abandon rescue work upon sighting a possible U-Boat track. It is also accepted that the capacity of submarines to engage in search and rescue is very limited, granted both their capacity and their extreme vulnerability to attack when on the surface. The risk was demonstrated when $U-156$ was (unsuccessfully) attacked by an unidentified aircraft whilst seeking to assist survivors from the sinking of the troopship Laconia. ${ }^{36}$ Best modern practice is perhaps represented by the action of H.M.S. Conqueror after the sinking of AR.A. General Belgrano in the 1982 Falklands Conflict, when, having sunk the major surface unit it departed the scene without attacking the smaller Argentine vessels leaving them to undertake rescue work unmolested. It must be added that although rescue may not always be possible, actual attack upon survivors hors de combat is clearly unlawful, now under article 12 and so held earlier in, e.g., the Llandovery Castle case $(1916)^{37}$ and the Peleus case $(1945)^{38}$

Once the wounded and sick have been collected it follows from article 12 of the first two 1949 Geneva Conventions that they must be given the most effective medical care which is practically available in accordance with their medical need. The requirement is broadly obvious in its implications but, again, the issue of practical possibility arises. Thus, wilful neglect and the creation of conditions exposing patients to contagion or infection are expressly forbidden by article(s) 12 , but an obvious distinction may here be drawn between 'impossibility' and 'culpable neglect'. To take specific examples, it may be impossible to screen donated blood for HIV infection in a field hospital but to fail to undertake basic sterilisation of surgical instruments would be inexcusable

Basic medical ethical standards are implicit in article 12 of the first two 1949 Conventions and are spelt out in more detail by article 11 of 1977 Additional Protocol 1. In particular, battlefield medical procedures must concord with 
'generally accepted medical standards' and be 'indicated by the state of health of the person concerned'. The only exceptions to this are voluntary (neither coerced nor induced) donations of blood for transfusion or skin for grafting, donation of organs for transplanting are forbidden even if volunteered.$^{39}$ This might, again, in practice require very difficult medical decisions in some cases but the provision is necessary to avert the medical atrocities which, especially in the case of 'ethnic and political' internees in the Third Reich, characterised the Second World War.

Medical personnel are also protected as a necessary dimension of the care of their patients. Permanent medical personnel are protected at all times, auxiliary personnel, such as stretcher bearers, are protected whilst actually engaged in medical work. ${ }^{40}$ They may not be penalised for carrying out their medical duties, including the treatment of enemy wounded, a point which is implicit in 1949Geneva Convention I, article 12, and made express by 1977 Additional Protocol I, article 16. Any full time medical personnel and chaplains who fall into enemy hands are not technically 'captured' but may be 'retained' for the provision of care to prisoners of war of their own or allied forces, being then protected by 1949 Geneva Convention III to at least the same extent 'as if' they were prisoners of war. The position of medical personnel and chaplains at sea is somewhat different. Together with the officers and crews of a hospital ship, they may neither be captured nor 'retained' whilst at sea, whether or not there are wounded and sick on board the ship. ${ }^{41}$ On land, however, such personnel, including any who have been brought to land after the sinking of a hospital ship, become subject to the relevant provisions of 1949 Geneva Convention I.

Medical institutions and transport are also protected. Fixed medical establishments and mobile medical units may not be attacked and must be respected and protected. They may come under enemy control but must then be permitted to 
continue with their medical work unless and until adequate provision is made by the enemy Power. ${ }^{42}$ Ambulances are similarly protected " This protection, like that of medical personnel, ceases only if units 'are used to commit outside their humanitarian duties, acts harmful to the enemy' and even then warning should be given if this is practically possible. ${ }^{4}$ Such 'acts' do not include, inter alia, the presence in a hospital of small arms and ammunition taken from patient or, again, the carrying of small arms by medical personnel. ${ }^{45}$

In an endeavour to facilitate their protection 1949 Geneva Convention I requires by article 19 that medical units be established so far as possible in places where they will not be imperilled by legitimate attacks upon military objectives. This means in particular that they must not be used as 'human shields' for potential military targets. If they are so used they are clearly placed at risk of 'collateral damage' which would then be the responsibility of those who had so misused them, provided that the concrete and direct military advantage anticipated from the attack was commensurate with the damage likely to be done.

Hospital ships, usually requisitioned merchant ships may similarly not be attacked or captured. ${ }^{46}$ The name and description of such ships must be notified to the other side not less than 10 days prior to their commencing operations. Hospital ships may be stopped and searched and may also be placed under the direction of a Commissioner (normally an enemy naval officer) or even detained for a period not exceeding seven days if the gravity of the circumstances so requires'." Warships of belligerent Parties may demand the surrender and hand-over of wounded, sick and shipwrecked on a hospital ship, so long as they are fit to be moved and the warship can itself provide adequate continuing medical treatment for them, ${ }^{48}$ which, in the nature of things, they normally could not. Protection is lost in the same way as for land medical units. ${ }^{49}$ 
Only very basic provision is made for medical aircraft by the 1949 Geneva Conventions, primarily by Convention I, article 36 and Convention II, article 39 . Such aircraft exclusively employed for the removal of the wounded and sick or the transport of medical equipment must not be attacked but must be repeated and protected whilst flying on routes and at altitudes and times agreed in advance. More extensive provision is made by 1977 Additional Protocol I, 'articles 24-31. These include particular rules defined by the nature of the territory overflown, but the basic principles are the same as those governing other modes of medical transport.

\section{The Protective Emblems}

The Red Cross and Red Crescent (the Red Lion and Sun formerly used by Iran has been de facto abandoned) are recognised under 1949Geneva Convention I, article 38 and Convention II, article 41 as protective emblems. They are used to identify units and personnel protected under the First and Second Conventions and are required to be worn or displayed by such personnel or units. Their improper use at any time is required to be penalised and in the UK is a criminal offence under the Geneva Conventions Act 1957, section 6. The emblems, of course, indicate rather than create protected status and do not function as a panacea against genuine accident. Thus, whilst (e.g.) a hospital should display the protective emblem it should not be attacked even if it does not do so if it is known or reasonably believed to be a hospital. An example of accidence may be seen in the sinking of the largest hospital ship ever lost in armed conflict, HMHS Britannic, a sister of the Titanic, in 1916 in a newly laid and undeclared minefield in the Aegean. The ship was displaying hospital ship colours but, despite Allied allegations of a major war crime, was the victim of a tragic accident. 


\section{The Red Cross and Red Crescent Movement}

The Red Cross emblem also gives its name to the International Red Cross organisation which similarly originated in the proposals made by Henry Dunant after the 1859 Battle of Solferino. It comprises national Societies, the International Federation of Red Cross and Red Crescent Societies and the International Committee of the Red Cross (ICRC). The organisation in its various dimensions undertakes much humanitarian work in armed conflict, including involvement in material humanitarian relief and in organising visits to prisoner of wear and other internment camps to check upon the conditions obtaining therein. The International Committee of the Red Cross also plays an important role in the continuing development of international humanitarian law through the medium of the international Red Cross conferences between the States Parties to the 1949 Geneva Conventions. ${ }^{50}$

\section{Protection of Prisoners of War}

Prisoners of war, as combatants in the custody of the enemy, are amongst the victims of armed conflict most at risk. The fate of Soviet prisoners in Germany, and of Axis prisoners in the USSR which was not party to the relevant 1929 Geneva Convention, in the Second World War made the point graphically. More recently, the abuse of Coalition prisoners in Iraq during the 1990-91 Gulf Conflict served to emphasise both the continuing importance and difficulty of this matter.

An obvious prerequisite for the implementation of protection is the determination of entitlement to prisoner of war (PoW) status. The basic category is defined by 1949 Geneva Convention III, article 4, as,

Members of the armed forces of a Party in conflict as well as members of military of volunteer corps forming part of such armed forces. 
Such forces must be under 'responsible' (i.e. hierarchically answerable) command, subject to a code of discipline which includes requirement to observe the laws of armed conflict, wear uniform or some other 'fixed distinctive sign' and carry their weapons openly. PoW status is also accorded to a variety of analogous and support personnel under 1949 Geneva Convention 111, article 4A and 1977 Additional Protocol I, article 43. PoWs are, however, always military or equivalent personnel of the parties in conflict.Personnel from other, non-involved, countries who are in an area of conflict and who are interned upon security grounds are not PoWs but are treated 'as if' they are 'civilian internees' under 1949 Geneva Convention IV. This was the situation of the British military mission in Kuwait at the time of the 1990 Iraqi invasion prior to British military involvement in the 1990-91 Gulf Conflict.

Spies and mercenaries are denied PoW status upon captured by 1977 Additional Protocol $I^{51}$ in which respect it almost certainly reflects established practice. Primafacie disentitlement from PoW status does not, of course, entail denial of entitlement to due process. PoW status should clearly not arbitrarily be denied without proper investigation, particularly by reference to 1977 Additional Protocol I, $\operatorname{articles} 45(3)$ and 75.

\section{Basic Principles of PoW Protection}

1949 Geneva Convention III sets out a detailed code for the organisation and management of PoW camps. It should be stressed at the outset that PoWs may not validly renounce the rights guaranteed to them by 1949 Geneva Convention III, and if they are coerced into purporting to do so this will be ineffective. ${ }^{52}$

Under the Convention, article 12, PoWs are the responsibility of the detaining Power from the moment of their capture, this means that mistreatment cannot be dismissed as 'unfortunate local zeal'. It is the duty of States to repress such abuses 
and to punish their perpetrators. Once in the hands of the enemy the basic protections afforded to PoWs are summarised by articles 13-16 of the Third Convention. Article 13requires that they must 'at all times be humanely treated' and any unlawful act or omission occasioning death or seriously endangering the health of a PoW is a serious breach of the Convention. It also reinforces the medical treatment protections set out in 1949 Geneva Conventions I and II and forbids reprisals against PoWs and exposure of them to 'violence or intimidation and ... insults and public curiosity ...'. The treatment of downed Tornado pilots in Iraq during the 1990-91Gulf Conflict was a manifest violation of this provision. Sensitive questions may arise in this context over media coverage of PoW camps and scenes of surrender, and did so, e.g., during the 1990-91 Gulf Conflict. The best conclusion would seem to be that photographs of an individual prisoner might be considered demeaning, but photographs of an 'anonymous' mass of prisoners would seem unlikely to be so.

Upon capture a PoW may be questioned but under article 17 of 1949 Geneva Convention III is only required to give surname, forename(s), rank, date of birth and serial number, or the equivalent information. Article 18 of the Convention requires that PoWs be evacuated as soon as possible after capture to camps situated far enough from the combat zone to be out of danger, although this may, of course, be delayed when moving them would in itself involve unnecessary exposure to combat danger. Once located in a PoW Camp (even if only a transit camp), the Convention requires by article 70 that a prisoner must, within one week, be enabled to write out a capture card according to a model set out in Annex IV B which will then be sent to the PoWs family and the International Committee of the Red Cross Central Tracing Agency in Geneva. 
There is no space in the present context for a detailed description of PoW camp administration, except to emphasise that PoW camps are in no sense penal institutions but are merely secure places of internment. Thus, subject to the proper exigencies of camp security, the religious, intellectual and recreational freedoms of prisoners are guaranteed by 1949 Geneva Convention III , articles 34-38. Prisoners of war may to varying degrees be required to work, although this limited to supervisory work in the case of NCOs and Officers may not be required to work but must be offered (supervisory)work if they so desire. In no case, however, may such work be directed to the war effort of the enemy. This point relates directly to, e.g., the PoW slave labour employed in the Nazi rocket programme factories in the Harz Mountains during the Second World War.

Prisoners of War are subject to penal and disciplinary sanctions under articles 82-108 of the Third Convention, with the injunction that the latter should be applied in preference to the former whenever possible. An interesting question arises where a PoW is suspected of having committed crimes prior to capture. The issue arose during the 1982 Anglo-Argentine Falklands Conflict in the so-called Astiz affair. ${ }^{53}$ Captain Astiz, who was captured by British Forces at the retaking of South Georgia, was suspected of possible involvement in the 'disappearance' of French and Swedish citizens during the 'dirty war' of internal Argentine repression under the Galtieri regime. Article $\mathbf{8 5}$ of the Convention implicitly permits trial upon charges arising from events prior to capture but such proceedings must, of course, comply with requirements of due process. Granted the difficulty of obtaining witnesses, especially defence witnesses, in such cases in circumstances of armed conflict this is rarely if ever likely to be possible. In these circumstances it was not possible to hand Captain Astiz over to France or Sweden for trial, and it may be, at the very least, strongly doubted the UK even had jurisdiction to try him. He was in fact asked a 
number of questions submitted by the French and Swedish authorities, all of which he, within his rights, refused substantively to answer. Captain Astiz was repatriated and eventually tried and acquitted in Argentina. ${ }^{54}$

Provision for release of prisoners of war is made by articles 118-9 of the Third Convention. The general, and obvious, principle is that prisoners should be repatriated as soon as may be possible after the close of hostilities, except for those serving judicial sentences or facing trial in accordance with norms of due process. A problem does, however, arise in relation to PoWs who may not wish to be repatriated for fear of persecution upon their return. The issue arose at the end of the Second World War when Soviet citizens who had fought with German forces were sent to the USSR at the end of the war to face immediate execution. ${ }^{55}$ Although article 109 still requires early repatriation it has become accepted that enquiries should be made, under ICRC supervision, as to whether PoWs actually desire to be repatriated or wish to apply for refugee status. ${ }^{56}$ The ICRC involvement is important as a means of ensuring that PoWs are not coerced into declaring a desire to remain in enemy hands with consequent propaganda gains to a detaining Power.

\section{Protection of Civilians}

Civilians were the last category of victims to be brought within the formal 'Geneva' remit, though 1949 Geneva Convention IV, although protection had been afforded prior to this, e.g. by the Land Warfare Regulations annexed to 1907Hague Convention IV. The protection of civilians clearly illustrates the overlap between the 'Hague' and 'Geneva' sectors in that a major part of the provision is concerned with targeting in bombardment and is as such considered below. Other provision in this area closely parallels relevant norms set out by 1949 Geneva Conventions I - III. 
The medical protection for civilian internees is set out in article 91 of 1949 Geneva Convention IV and includes requirements of appropriate health provision. 1977 Additional Protocol I, by article 8(a), effectively abolished any residual distinction between military and civilian patients. The regime set out for civilian internees by 1949 Geneva Convention 111, articles $70-141$, is closely similar to that set out for prisoners of war by 1949 Geneva Convention III although made in some respects more lenient in form to take account of the general unfamiliarity of civilians with living under military discipline. These considerations include the keeping of family members together. ${ }^{57}$

Particular questions arise in connection with the governance of occupied territories. The basic principle is that an Occupying Power has only a temporary governing authority of necessity, a point emphasised by the Land Warfare Regulations annexed to 1907 Hague Convention IV, article 43, and it is further provided , by article 42 , that occupation is a matter of military fact rather than technical definition or entitlement. This point is reinforced by the fact that, pursuant to the 1928 Pact of Paris and article 2(4) of the UN Charter, armed conquest has ceased to be a legitimate mode of territorial acquisition. ${ }^{58}$ Thus despite the, very dubious, territorial claims which it made over Kuwait during the 1990-91 Gulf Conflict, Iraq remained an Occupying Power in the Emirate and was fully bound by the law pertaining to occupation.

It is generally the duty of an Occupying Power to ensure so far as possible the continuation of normal governance and facilities within the territory. Administrative and legal changes may be made by the Occupying Power, but only when this is objectively required by military necessity. ${ }^{59}$ Any such changes are not permitted to deny the protection of the 1949 Conventions to inhabitants of the territory. ${ }^{60}$ Facilities, including medical facilities, may be requisitioned for the use of the 
occupying forces but in the case of a civilian medical unit appropriate equivalent provision must be made for the displaced patients. ${ }^{61}$ Under no circumstances may the inhabitants of an occupied territory be required to swear allegiance to the Occupying Power ${ }^{62}$ or to serve in its armed forces. ${ }^{63}$ If people choose, without pressure or inducement, to serve in the enemy forces that will be a matter for them, although they will no doubt then be committing a criminal offence in the law of their home Power.

Methods and Means of Warfare Target Selection and Bombardment

The general principle is that bombardments must be directed against military objectives. These are usefully defined 1977 Additional Protocol I, article 52(2) as,

those objects which by their nature, location, purpose or use make an effective contribution to military action and whose total or partial destruction, capture or neutralisation, in the circumstances ruling at the time, offers a definite military advantage.

This provision is not in itself formally customary law but it summarises principles deriving from, e.g., the 1907 Hague Land Warfare Regulations (annexed to 1907 Hague Convention IV) which clearly do have customary status. This also means that a bombardment must not be indiscriminate (i.e. failing or unable to select between military and civilian targets - usefully summarised by 1977 Additional Protocol 1, article 51(2)). The general principles are set out in The Hague Land Warfare Regulations, articles 25, 26 and 27 and re-emphasised by 1977 Additional Protocol I, articles 48, 51, 52 and 57. Terror attacks are specifically forbidden by article 51(2), essentially repeating a principle set out in article 22 of the 1923Hague Draft Rules on Aerial Warfare which, whilst they never came formally into force, were accepted as a 
summary of existing customary principle.. Article 52(3) of 1977 Additional Protocol I further states that in case of doubt a target should be presumed to be civilian.

Modern questions arising upon these rules and principles include the matter of automated weapons which have a much more rapid response time, and therefore limited time for consideration, in comparison with the weapons systems of 1907 and even 1949. The point was illustrated by the shooting down of an Iranian airliner in a combat zone by USS Vincennes in a convoy protection action during the 1980-88Gulf War. Although the management of the Vincennes was severely criticised by the subsequent Court Martial. the Commanding Officer was clearly faced with an unenviable choice between either risking the destruction of his ship by a hostile aircraft or risking the shooting down of a civil airlines - as in fact happened.

The military implications were illustrated by the choice of high altitude bombing as the sole method of attack during the initial NATO campaign in the 1999 Kosovo crisis. A number of serious questions arose from this, including the politically disastrous accidental bombing of the Chinese Embassy in Belgrade. It must also be remembered that 'human shield' tactics are unlawful and cannot as such serve to protect a legitimate military target. Examples may be seen in the use by Iraq of PoWs and civilian internees as 'shields' for military targets in the 1990-91 Gulf Conflict. It was also claimed that Kosovar Albanians were being used as 'shields' by the Serbian forces in Kosovo in 1999. Note also the issue of 'collateral damage': some damage to non-military targets may well be unavoidable, but all practical measures must be taken to minimise it, including calculations of the actual military advantage to be anticipated from the attack." 
Both involve deceiving the enemy in order to gain a military advantage. The former are lawful but the latter is not. A ruse of war is an attempt to mislead the enemy or to cause him to act recklessly which does not invite reliance upon any protected legal status or emblem. Examples would include:

(i) The use of a false fourth funnel by the cruiser SMS Emden in order to confuse identity with a British 'Town' class cruiser during a First World War raid on Penang. (ii) British deployment of propaganda to the effect that a much more powerful RN force, including HM Ships Renown and Ark Royal, was gathering off the river Plate following the engagement with KM Graf Spee. This deceit first impeded the German ship from coming forth and certainly contributed to the decision to scuttle the vessel.

Perfidy means any act by which enemies are led to believe that they are entitled to or obliged to accord protection under international law. Examples might include false use of Red Cross or Red Crescent emblems or a white flag, feigning neutral or UN status, or sickness or injury. It might also include deceitful wearing of (false) uniform or feigning civilian status. ${ }^{65}$ Many of these acts are unlawful per se. The ban upon perfidy as such is codified by art. 37 of 1977 AP I. It is important to be aware of the circumstances in which confidence is invited. The British officer killed by flanking fire from another enemy unit when responding to a white flag during the 1990-91 Gulf conflict was not a victim of 'perfidy' - he would of course have been so had the fire come from the unit displaying the white flag.

\section{Orders of 'No Quarter'}

Orders of 'no quarter', i.e. that there shall be no survivors from an enemy force, are banned by art. 40 of 1977 AP 1 .It is also banned by art. 23(d) of the Land Warfare Regulations annexed to 1907 Hague Convention IV. The notorious World War II 'Commando Order' under which German Forces were ordered not to take 
Allied Commandos prisoner was held by the International Military Tribunal at Nuremberg to have violated this provision.

\section{Reprisals}

These are prima facie unlawful acts undertaken in response to prior unlawful acts of the enemy. International humanitarian law places major restrictions upon belligerent reprisals especially in regard to persons protected under 'Geneva' Law. ${ }^{66}$ Where reprisals may be lawful (i.e. not violating fundamental humanitarian norms) this should still not be taken as a counsel for a mere matching of atrocities.

\section{Arms Control}

The underlying principle of the law of arms control is the doctrine of 'unnecessary suffering' set out in the Preamble to the 1868 Declaration of St. Petersburg ${ }^{67}$ which may be said also to embody an implicit doctrine of 'excessive cruelty'. It cannot, however, be said that these principles have been applied coherently or consistently and the resulting law is essentially a patchwork quilt of treaties reflecting successive foci of concern with real or supposed horror weapons. It must here be emphasised that this discussion concerns weapons which are categorically banned or restricted and it must be borne in mind, in the light of the rules upon bombardment outlined above, that certain uses are banned in respect of all weapons whether or not they are inherently lawful as such. The most important bans may readily be listed and comprise:

Small calibre (less than 4 gr. weight) explosive projectiles (1868 Declaration of St. Petersburg)

Expanding Bullets, i.e. those without or with a perforated hard casing 'Dumdum bullets' (1899 Hague Declaration 3)

Unanchored submarine contact mines (1907Hague Convention VIII) Gas, Chemical and Biological Weapons use, reservations mean in effect first use, (1925 Geneva Gas Protocol) 
Bacteriological Weapons, including all use and stockpiling, (1972 UN Bacteriological Weapons Convention)

Certain hostile macro-environmental modification weapons (1977 UN Environmental Modification Techniques Convention- ENMOD)

Also under 1981 UN Conventional Weapons Convention and Protocols:

(i) Fragmentation weapons leaving fragments in the human body undetectable by X Rays (Protocol I)

(ii) Indiscriminately used mines, booby traps and similar devices (Protocol11)

(iii) Incendiary Weapons directed against civilian populations

(iv) Blinding laser weapons

(v) Land Mines. Chemical weapons, including all use and stockpiling, (1992 UN Chemical Weapons Convention).

The effectiveness of arms control is a somewhat controversial issue. Many significant bans, including those upon small-calibre explosive projectiles, dumdum bullets and chemical (gas) weapons have achieved a very large measure of efficacy. The latter in particular offers a useful case study. An attempt was made to ban such weapons at the 1899 Hague Peace Conference but this collapsed in the face of the use of gas warfare on the Western Front during the First World War. ${ }^{68}$ The horrors of this left a deep impression and the weapon also proved highly unreliable in so far as a change of wind direction could turn it back upon those who had launched it - as happened to a Bavarian infantry regiment in which one Corporal Hitler was serving. It also failed ultimately in its use as a means of breaking the Western Front infantry deadlock, this being achieved later through the invention of the tank. The subsequent 1925 Geneva Gas Protocol has been a generally successful measure, violated on only a few occasions, notably by Italy in Ethiopian under Mussolini, by Japan in the second Sino-Japanese War (merging into World War II in the Far East) and by Iraq in the 1980-88 Gulf War.. This relative success may be out down to a combination of moral revulsion - with the associated diplomatic risks involved in use, the practical defects of the weapon on the battlefield and the probability of devastating retaliation in the case of its employment. 
The legal status of nuclear weapons was considered in 1996 by the International Court of Justice in the Advisory Opinion upon Nuclear Weapons. The Court declined to hold that nuclear weapons are unlawful per se, but held that most uses of such weapons would be so, inter alia upon grounds of indiscrimination., confirming that the general jus in bello applies to nuclear weapons as much as to any other armaments. The Court held, however, that use of nuclear weapons might be lawful in certain extreme circumstances, as, e.g., in case of imminent threat of national extinction. The opinion has been much criticised by a number of campaigning and non-governmental organisations as being too timid in its response, but in fact it appears to state accurately the law as it currently exists which is the proper limit of the Court's action under its Statute. There are some regional bans e.g. the Treaties of Rarotonga and Tlatelolco. In 1999 the issue again became prominent with the emergence of India and Pakistan as nuclear capable military powers in the context of the dispute over Kashmir. The question of nuclear proliferation has also become a general concern since the collapse of the former-Soviet Union and a weakening of nuclear security in some areas of the former bloc.

\section{Conclusions: Laws of Armed Conflict into the 21st Century}

The laws of armed conflict, in both their jus ad bellum and jus in bello dimensions, evolve just as armed conflict does so itself. The basic norms are hardly subject to fundamental change in any currently conceivable circumstances, but new issues arise from time to time which may demand new provision - such as the 1977 Additional Protocols to the 1949 Geneva Conventions, or new applications in changed circumstances. The post-Cold War reorientation of international peace support and enforcement mechanisms is an important example of this form of 
process at the point of transition from the 20th to the 21st century. Certain arguments pertaining to humanitarian intervention might be thought to suggest a need for radical reinterpretations of, or even amendments to, the UN Charter. The wisdom of this may however be doubted, since many of the claimed, and even actual, cases of 'humanitarian' provisions fall readily within the existing remit of action for the maintenance or restoration of international peace and security - which the situations tend by their nature to threaten. Areas of change or expansion in international humanitarian law may demand attention, not least in the context of non-international armed conflicts including in particular in relation to the victimisation of civilians in processes of so-called 'ethnic cleansing'. It is unwise to make overly specific predictions about future patterns of armed conflict, which tend swiftly to be proved false in practice, but it may at least be suggested that these will be some of the issues which will influence the next phase of legal development in this area.

1 C. von Clausewitz, Vom Kriege (On War), 1832, trans. J.J. Graham, ed. F.N. Maude (Routledge and Kegan Paul, 1908; abridged edn. Penguin, 1968, 1982), p.102.

2 The term "armed conflict" is now preferred to "war" since the latter has come to mean a formally declared condition of international relations of which there have been no significant examples since 1939.

3 K. Kuhn, 'Responsibility for Military Conduct and Respect for International Humanitarian Law' Dissemination, ICRC, (1987), p. 1.

4 Sun Tzu, The Art of War, ed. 1. Clavell, (Hodder and Stoughtin, 1981), Chapter VI, para. 36 See J.C. Morris and H. McCoubrey, 'Regional Peacekeeping in the Post-Cold War Era' (1999) 6 International Peacekeeping,pp. 129-151.

$5 \quad$ See J.C. Morris and H. McCoubrey, 'Regional Peacekeeping in the Post-Cold War Era' (1999) 6 International Peacekeeping, pp. 129-151.

6 Granted that the aim of this law is to constrain resort to armed force, there are those who argue that a more appropriate designation might be the jus contra bellum (the law against war), see G. Herczeg, Development of International Humanitarian Law, trans, S. Simon and L. Czante (Akademiai Kiado, 1984).

7 See below. 
8 See K.N. Llewellyn, "The Normative, the Legal and the Law Jobs: The Problem of Juristic Method" (1959-60) Yale Law Journal, 1355.

$9 \quad$ For discussion see, e.g., S. Roberts. Order and Dispute: An Introduction to Legal Anthropology (Penguin, 1979)

10 See G. I. A. D. Draper, "The Origins of the Just War Tradition" New Blackfriars Vol. 46 (1964), pp.82-88; substantially reproduced in Reflections on Law and Armed Conflicts: The Selected Works on the Laws of War by the late Professor Colonel GIAD Draper, OBE, ed. M.A. Meyer and H.McCoubrey, (Kluwer Law International 1998), at pp.5-9.

$11 \quad$ For discussion see P, Contamine, trans. M.Jones, War in the Middle Ages (Basil Blackwell, 1984; first published by Presses Universitaires de France in 1980 as La Guerre au Moyen Age), Ch. 10.

For discussion of the significance of the Peace of Westphalia, see L. Gross, "The Peace of Westphalia, 1648-1948" (1948) 42 American Journal of Znternational Law, p.20.

13 For a broad ranging discussion see H. Bull, B. Kingsbury and A. Roberts, Hugo Grotius and International Relations (Oxford University Press, 1990).

14 Including figures such as Francsico de Vitoria and Balthazar Ayala.

15 His principal work in this area was De Jure Belli published in its final form in 1598, available in translations, trans. F.W. Kelsey et at., (Oxford University Press, 1933).

16 Also known as the Kellogg-Briand Pact.

17 Disputes over oil rights had existed between Iraq and Kuwait for some years before Iraq began to assert claims of sovereignty over the Emirate.

18 With regard to the debates at San Francisco see, L.M. Goodrich and E. Hambro, Charter of the United Nations: Commentary and Documents (Stevens. 1949), pp. 262-265.

19 See H. McCoubrey, 'Kosovo, NATO and International Law', (1999) XIV Znternational Relations, pp.29-46.

${ }_{20}$ N.D. White, Keeping the Peace (Manchester University Press. 1997), p.45

$21 \quad$ For discussion of the general point see N.D. White, "Collective Sanctions: An Alternative to Military Coercion?" (1994) XII International Relations,pp. 75- 91

22 For discussion see E. Grove, 'UN Armed Forces and the Military Staff Committee: A Look Back', International Security, Vol. 17No. -1. (1993), pp. 172-82.

23 'For discussion, see H. McCoubrey and N.D. White, The Blue Helmets: Legal Regulation of United Nations hlilitarv Operations (Dartmouth. 1996), p.13 ff.

$24 \quad$ See I.L. Claude, Swords into Plowshares, 4 ed., (McGraw Hill, 1984) at p.143, citing The Memoirs of Cordell Hull, II, 1662,1664.

25 Better known as the US-led 'Operation Restore Hope'.

26 Report of the Secretary-General on the Work of the Organization, United Nations: A/50/60 -S/1995/1, 3 January 1995 
The present writer has undertaken a major study of this development in collaboration with J.C. .Morris of the University of Hull Department of Politics and Asian Studies and the University of Hull Centre for Security Studies. See Regional Peacekeeping in the Post-Cold WarEra (Kluwer Law International, 2000).

An extensive historical analysis will be found in G. Best, Humanity in Warfare (Methuen, 1983; first published by W《idenfeld \& Nicolson in 1980).

$29 \quad$ See above

30 See G.I.A.D. Draper. 'The Penitential Decrees and the Battles of Hastings and Soissons', Znternational Review of the Red Cross, May 1964, p,63; substantially reproduced in M.A. Meyer and H. McCoubrey, eds., Reflection on Law and Armed Conflicts: The Selected Works on the Laws of War by the late Professor Colonel GIAD Draper, OBE, (Kluwer Law International, 1998) at pp.26-32.

31 For discussion see P. Contamine, op.cit., Ch. 10.

32 See J. Pictet, Development and Principles of International Humanitarian Law (Marfnus Nijhofl; 1985), pp. 21-25

33 Republished in translation by the American National Red Cross in 1959.

34 See C. Greenwood, 'Customary Law Status of the 1977 Additional Protocols' in AJM. Delissen and GJ. Tanja, Humanitarian Law ofArmed Conflict: ChallengesAhead (Martinus Nijhofl; 1991), pp. 93-114

3s 1949 Geneva Convention I, article 15; Convention 11, article 18.

36 The resulting "Laconia Order" forbidding U-Boats to engage in search rescue under any circumstances was later held unlawful because of its absolute terms, if it had merely forbidden commanders to place their submarines at unacceptable risk it would merely have reflected general practice.

37

Reported (1922) 16 American Journal of International Law, p. 708.

38 Vol. I., War Crimes Trials (William Hocky \& Co., 1948)

$39 \quad 1977$ Additional Protocl II, article 11(2)(3)

Ibid., article 21.

40 See 1949 Geneva Convention I, articles 24-28.

$41 \quad 1949$ Geneva Convention II, article 36

421949 Geneva Convention I, article 19.

$43 \quad$ Ibid., article 35

$44 \quad$ Ibid. article 21

$45 \quad$ Ibid. article 22

$46 \quad 1949$ Geneva Convention II, article 22

$47 \quad$ Ibid. article 31

$48 \quad$ Ibid. article 14

$49 \quad$ Ibid. article 34

so For further discussion see H. McCoubrey. International Humanitarian Law, 2 ed., (Ashgate, 1998), Chapter 2.

$51 \quad$ Articles 46 and 47 respectively

521949 Geneva Convention 111, article 7. 
$53 \quad$ For discussion see M.A. Meyer. 'Liability of Prisoners of War for Offences Committed prior to Capture: The Astiz Affair (1983) 32 International and Comparative Law Quarterly,p. 948.

54 For discussion of war crimes trials, which were not at issue in the Astiz affair. see below.

55

These incidents were later the subject of a highly controversial book, Victims of I'alta (first published by Hodder and Stoughton in 1977: Corgi, 1979)written by Count Nikolai Tolstoy, which because of the specific attribution of blame led to a successful libel action, for a legal analysis of these repatriations see. however, GIAD. Draper, "Some Legal Aspects of Forced Repatriation of Soviet Citizens" (published as an Appendix to the Tolstoy book. reproduced in M.A. Meyer and H. McCoubrey, eds., Reflections upon Law and Armed Conflicts: The Selected Works on the Laws of War by the later Professor Colonel GL-ID Draper, OBE (Kluwer Law International, 1998), pp.255-268.

56 See P. Rowe, 'Prisoners of War in the Gulf Area' in P. Rowe, ed., The Gulf liar 1990-91 in International and English Low (Sweet \& Maxwell/Routledge, 1993), p.188 at p.293

$57 \quad 1949$ Geneva Convention IV, article 82.

58 Under the intertemporal rule earlier historic acquisitions were not thereby disturbed.

59 Land Warfare Regulations annexed to 1907 Hague Convention IV, article 43, and 1949 Geneva Convention N, article 64

601949 Geneva Convention IV, article 47.

$61 \quad$ Article 57.

62 Land Warfare Regulations annexed to 1907Hague Convention IV, article45

631949 Geneva Convention IV, article 51.

64 The issues are usefully summarised by article 57(2)(a)(iii) and (b).

65 A well known, and controversial, case may be found in the operations led by Colonel Otto Skorzeny during the Battle of the Bulge at the end of the Second World War, see P. Rowe Defence: The Legal Implications (Brassey's Defence Publishers, 1987), pp. 112-113.

66 See 1949 Geneva Convention 1, article.46; Convention II, article.47; Convention 111, article 13; Convention N, article.33;\#; and 1977 Additional Protocol 1, articles 56(1) and 53.

67 See above.

68 Ges was also used on the Eastern Front but to a much lesser extent in view of the absence of a longrunning static infantry confrontation. 


\section{The Causes of War and the Conditions of Peace \\ Professor J.C. Garnett \\ University of Wales}

\section{Opening:Summary}

Scholarship dealing with the causes of war is voluminous and multi-disciplinary. The aim of this chapter is fourfold. First, to describe and explain the most important theories that have been advanced by biologists, philosophers, political scientists and sociologists about why wars occur. Second, to group their ideas into categories which are intellectuallymanageable; third, to elaborate a series of analytical distinctions between different kinds of cause which will enable us to get a handle on the multitude of diverse explanations for war which have been suggested, and fourth, to show how different explanations of war give rise to different requirements or conditions for peace. Distinctions are drawn between 'immediate' and 'underlying' causes of war, between 'permissive' and 'efficient' causes, between 'learned' and 'instinctive' causes, and between 'necessary' and 'sufficient' causes. The chapter pays particular attention to 'human nature' and 'instinct' explanations of war, but it also considers those psychological theories which emphasize 'misperception' and 'frustration' as causes of aggression. The ideas of those who find the causes of war in human collectives - states, tribes, ethnic groups etc, and those who favour 'systemic rather than 'unit' explanations are examined in detail. The focus is on ideas rather than facts but historical examples are used at every opportunity to illustrate theoretical points. 


\section{Introduction}

Though 'strategy' these days is as much concerned with the promotion of peace as it is with the conduct of war, the phenomenon of war remains a central concern. Previous generations might have seen virtues in war, for example, as an instrument of change or as a vehicle for encouraging heroic virtues, but these ideas have been rendered obsolete by the destructiveness of modern warfare. In the $20^{*}$ Century abolishing war became a top priority and it is argued that the first step in this direction is to identify its causes.

Historians sometimes argue that since wars are unique events, the causes of war are as numerous as the number of wars and nothing in general can be said about them. This chapter takes a different view. It seeks to identify similarities and patterns between the causes of one war and another so' thatwe can group causes under such .headings as 'human nature', 'misperception', 'the nature of states' and 'the structure of the international system'. Its overall aim is twofold. First, to relate contemporary scholarship across a range of disciplines - biology, political science, philosophy, history, etc - to the problem of war causation, and second, to elaborate a number of distinctions which help us to identify different kinds of 'cause', e.g., 'underlying' and 'immediate' causes, 'conscious' and 'unconscious' motives. Throughout the chapter these distinctions are used to analyze the various causes of war and to discriminate between them.

Since there is little scholarly agreement on what causes war attention is directed more towards explaining the debate than to answering the question in a decisive way. The arguments are more than academicbecause, if the cure for war is related 
to its causes, then different causes will lead to different policy recommendations. If, for example, wars are caused by arms races then policies of disarmament and arms control will be judged appropriate solutions to the problem of war. On the other hand, if it is believed that wars are caused by despotic or authoritarian states then the way to peace lies in the spread of democracy. If the basic cause of war is deemed to be the 'international anarchy' which characterizes the current system of states then attempts to rid the world of war will be geared towards promoting 'system change' perhaps in the direction of strengthened international law or a system of collective security or world government.

Clearly, some explanations for war offer less hope for solutions than others. For example, those that locate war in a fundamentally flawed human nature suggest a more bleak future for the human race than those that locate the causes of war in 'learned 'behaviour. If war is learned rather than instinctive then there is a possibility that it can be eliminated through social engineering. Three conclusions emerge from this analysis. First, that the search for a single cause appropriate to all wars is futile, and second, that since war comes in a variety of forms and has a multiplicity of causes, its elimination will almost certainly require simultaneous political action on a variety of levels, both domestic and international. Third, that a world-wide 'just' peace is unattainable. 


\section{The Study of War}

In the field of International Relations no question has attracted more attention than 'Why war?' The reason for this interest is that war is almost universally regarded'as a human disaster, a source of misery on a catastrophic scale, and, in the nuclear age, a threat to the entire human race. But it is worth noting that war has not always been viewed so negatively. In the 19C, for example, numerous writers identified virtues in war. Hegel believed that war preserved the ethical health of nations, and in a similar vein $\mathrm{H}$. von Treitschke regarded war as "the only remedy for ailing nations". (Gowans 1914:23). For him, war was one of the conditions for progress, the cut of the whip which prevents a country from going to sleep, forcing satisfied mediocrity to leave its apathy. This kind of thinking alerts us to the idea that war can be thought of as a purposive, functional thing. E.H. Carr regarded it as 'the midwife of change' (1942:3) "Wars .... Break up and sweep away the half-rotted structures of an old social and political order". They herald rapid technological progress, territorial change, strengthened group consciousness and economic development. However, the idea of war as a purposive, functional thing sits uneasily in an age which typically interprets war as an abnormal, pathological condition which threatens us all.

Most investigators into the causes of war have not been motivated by idle curiosity or an aimless spirit of enquiry. They have studied war in order to abolish it. They have believed that the first step towards eliminating war is to identify its causes because, in much the same way that the cures for disease are related to the causes of disease, so the cures for war are to be found in its causes. So long as students of war do not allow their enthusiasm for prescription to affect their diagnostic skills no 
harm is done, but there is a danger that researchers may be tempted to gloss over the more intractable causes of war in favour of those which suggest the possibility of solutions.

Many social scientists recoil from the idea that though particular wars may be avoided, war is endemic in the human condition. The idea that war is inevitable is pretty difficult to swallow, psychologically speaking, and that may explain why pessimistic interpretations of the causes of war meet with resistance. Take, for example, the view that the root cause of war is to be found in human nature, that aggression and violence are genetically built into all human beings, that we do what we do because of what we are. Despite some scientific evidence in support of this idea, there is enormous resistance to it. Why? Because since human nature is fixed there is not much we can do about it. That is, for many, an intolerable counsel of despair even though it is a useful reminder that just because the elimination of war is desirable does not mean that it is therefore possible.

Actually, even a gloomy interpretation of human nature and an admission of its intractability does not automatically lead to despair of ever being able to rid the world of war. Some would argue that wars are not caused by human nature: they are caused by human behaviour.

And while it may not be possible to change human nature, it is certainly possible to modify human behaviour - by offering rewards, by making threats, by education programmes, by propaganda, etc. Richard Dawkins has pointed out that 'ar genes may instruct us to be selfish but we are not necessarily compelled to obey them all our lives' 'It may — be more difficult to learn altruism than it would be if we were 
genetically programmed to be altruistic",but we should try "to teach generosity and altruism, because we are born selfish"(1976:3). Civilized societies spend a great deal of energy on making people behave themselves despite their natures. The law, the police, schools and churches all play a part in modifying human behaviour in the domestic environment. At the international level the possibility of modifying state behaviour is also widely recognized. Diplomacy, force, trade, aid and propaganda are all instruments used by statesmen to affectthe behaviour of the states they are dealing with. Deterrent strategists, for example, argue that even if human nature is fatally flawed ( and most of them think it is), states can still be deterred from aggression by the threat of unacceptable punishment in much the same way that many potential criminals can be deterred from robbing banks by the threat of imprisonment.

What is interesting is that unlike those who believe that peace can best be promoted by removing the causes of war, nuclear deterrent strategists hardly care at all about why wars occur. Their policy is simply to make the consequences of war so bad that nobody will dare fight even if they want to. In other words, the strategy of nucleardeterrence is unique in that its effectiveness does not depend either on particular interpretations of why wars occur or on any virtuous conceptions of human nature. The only assumption that deterrent theorists make about human beings is the fairly uncontroversial one that on the whole people prefer to be alive than dead and hence are likely to be deterred from aggression by the threat of annihilation. 


\section{Difficulties in Studving War}

Despite the enormous attention devoted to the question 'Why war?', no clear authoritative answer has emerged, and perhaps one never will. One of the reasons for this is that the term 'war' is a blanket term which is used to describe very diverse activities. There are total wars and limited wars, regional wars and world wars, conventional wars and nuclear wars, high technology wars and low technology wars, inter-state wars and civil wars, insurgency wars and ethnic wars, and in recent years we have had wars fought by coalitions on behalf of the international community. It would be very surprising if these widely different activities - linked only by the fact of organized military violence - could be explained in the same way.

Another reason for the absence of an authoritive answer is that the question ' what are the causes of war?' is a complicated, 'cluster' question. Under its umbrella, as Suganami has pointed out, we may be asking a number of differentquestions. We may, for example, be asking 'What are the conditions which must be present for wars to occur?', or we may be asking 'under what circumstanceshave wars occurred most frequently?', or we may be asking about how a particular war came about.(1996: 4). Lumping these questions together inevitably leads to complicated and diverse answers.

A third reason for complex answers to the question of war causation is that the concept of 'causation' itself is fraught with philosophical difficulties. One may note that $\mathrm{X}$ is often a prelude to $\mathrm{Y}$, but that i s not at all the same as proving that $\mathrm{X}$ caused Y. Various writers, for example, noting that wars are often preceded by arms races between the belligerents, have claimed that arms races cause wars. They may do 
sometimes, but an automatic connection is less than proved. Arguably, human beings do not fight because they have weapons; they acquire weapons because they already wish to fight. And it is worth pointing out that not all arms races have led to war. Anglo French naval competition in the $19 \mathrm{C}$ led to the Entente Cordiale, and the Cold War arms race between the United States and the Soviet Union led to a deterrent stalemate and one of the most prolonged periods of peace in European history.

Given the difficulties inherent in the problem of causation, some writers (particularly historians) have preferred to talk about the 'origins' of wars rather than 'causes'. Their argument is that the best way of explaining why wars occur is to describe how they come about in terms of the background and events from which they spring. Thus, if we are investigating the causes of the Second World War, we need to look at the Treaty of Versailles, the world depression, the rise of Hitler, German rearmament, the foreign policies of Britain and France, etc. When we have done this we are well on the way to understanding why the Second World War occurred. Those who emphasize the 'origins' of war hold the view that telling the story of how they are come about is as close as we can get to understanding why they come about.

Historians who favour this very specific, 'case-study' approach to the identification of the causes of war tend to believe that since every war is a unique event with unique causes the causes of war are as numerous as the number of wars. Hence, providing an authoritative answer to the question ' what are the causes of war?' would involve a detailed examination of every war that has ever occurred. The uniqueness of every war means that there is nothing in general to be said about 
them. For investigations concerned with the causes of individual wars this a fair point. Nevertheless, while acknowledging the uniqueness of individual wars, most political scientists see merit in shifting the level of analysis from the particular to the general so that we can see patterns and similarities between the causes of one war and another. At this more general level of analysis we may identify some causes which are common to many, if not all, wars.

\section{'Immediate' and 'Underlving' Causes}

One of the most useful distinctions to be drawn between the various causes of war is that between 'immediate', proximate causes and 'underlying', more fundamental causes. Immediate causes, the events which trigger wars, may be trivial, even accidental. For example, the spark which ignited the First World War was the assassination of the Austrian Archduke Franz Ferdinand who was visiting Sarajevo and being driven in an open car. The death of the Archduke was a tragedy, but is was essentially a trivial event, and no one seriously believes that its occurrence provides an adequate explanation for the momentous events which followed. What is more, it was an 'accident' which might easily not have happened. If the duke's chauffeur had not deviated from the planned route and then stopped the car in order to rectify his error, the assassin would not have had an opportunity to shoot the Archduke and his wife. The assassination was undoubtedly the immediate cause of the First World War, and it is true to say that if it had not happened the war which broke out in $\mathbf{1 9 1 4}$ would not have happened. But there is plenty of evidence to suggest that a war would have occurred sooner or later. In 1914 war was in the air; Europe was divided by hostile alliance systems; tensions were rising; mobilization timetables were pressuring decision makers; an arms race was underway. In short, 
the background circumstances were highly inflammable and if the assassination of Franz Ferdinand had not set the powder keg alight, sooner or later something else would surely have provided the spark. Most commentators believe that a proper examination of the causes of the First World War should pay more attention to those underlying causes than to the immediate triggering events.

Emphasis on underlying causes is a structural interpretation in the sense that it emphasizes that importance of international circumstances rather than deliberate policies in causing wars. It suggests that statesmen are not always in control of events; they sometimes find themselves caught up in a process which ,despite their best intentions, pushes them to war. Suganami has pointed out that there are occasions when "the background conditions appear already so war prone that the particular path through which the actual war broke out se e m only to have been one of a number of alternative routes through which a war like that could have been brought about". (1996: 195)

Of course, this is not always the case. In some situations the setting s e e m relatively benign and responsibility for war is more easily allocated to the particular policies followed by the governments involved. Wars often come about as a result of aggressive, reckless, thoughtless and deliberate acts by statesmen. It would be impossible to discuss the causes of the Second World War without drawing attention to the persistently aggressive behaviour of Hitler and the weak, appeasing policies of Chamberlain. Similarly, the actions of Nasser in seizing the Suez Canal and Eden in responding to it with military action were critically important causes of the Suez war. The same point can be made about both the Falklands war and the Gulf war. 
In the case of the Falklands, the Argentinian decision to invade South Georgia and Margaret Thatcher's decision to resist seem at least as important as any 'structural' causes which might be identified. In the case of the Gulf War, Saddam Hussein's decision to seize territory in Kuwait and the decision of Western governments not to allow him to get away with it were more obvious causes of the Gulf War than any background circumstances.

\section{'Efficient' and 'Permissive' Causes}

Another useful distinction, not too different from that between 'underlying' and 'immediate' causes of war, is that which distinguishes between 'efficient' and 'permissive' causes. 'Efficient' causes are connected to the particular circumstances surrounding individual wars. War may result because state $\mathbf{A}$ has something state $B$ wants. In this situation the 'efficient'

cause of the war is the desire of state B. Historical examples abound. The efficient cause of the Gulf war between Iraq and Iran was the desire of Saddam Hussein to regain from Iran the Shatt-al-Arab waterway; the efficient case of the 1990war between Iraq and the Western Coalition was Saddam's desire to acquire Kuwaitan territory and resources which, rightly or wrongly, be believed should have belonged to Iraq.

'Permissive' causes of war are those features of the international system which, while not actively promoting war, nevertheless allow it to havoen. In this context, the fact that we live in a world of independent sovereign states with no authority above them and no institutions sufficiently powerful to regulate the relations 
Kenneth Waltz is renowned for the emphasis which he puts on 'permissive' rather than 'efficient' causes of war.(1959) Basically his argument is that though the causes of war are bewildering in their variety, the most persuasive explanation for it is to be found in international anarchy - the fact that in an ungovemed international system there is nothing to prevent it. And because there is nothing to prevent war there is, in international relations, a permanent expectation of violence and a permanent sense of insecurity which pushes states to behave aggressively despite whatever peaceful intentions they may have. Waltz uses Rousseau's famous 'stag hunt' analogy (See Box 2) to show that warlike behaviour arises not primarily from any defect in human nature or states but from the predicament in which statesmen find themselves.(1959: 167-68). In the face of systemic or structural inadequacy, war cannot be avoided for ever and is always just around the comer.

Kenneth Thompson has made the same point in a slightly different way. (1960:261276). He imagines a situation where, during the rush hour, someone waiting for a train on the platform of a metro-station finds himself being pushed by a surging crowd of fellow travelers towards the electrified line. Our passenger is a good man who means no harm. What should he do? The Christian ethic tells him to turn the other cheek, but if he does he will end up dead on the rail tracks. And so our good man kicks and struggles and fights to stay alive. He behaves in this aggressive way not because he is wicked or violent, but because he finds himself in an environment where he cannot afford to be good. The Sermon the Mount is not much use if you live in the jungle. And so it is with states; it is because they exist in a system where others behave badly that doing likewise is the only way to survive. 
If the main cause of war is to be found in the anarchic international system in which sovereign states pursue their interests without the constraint of world government, then an essential condition of peace is the transformation of that system from one of competing states to a unified world ruled by a single authority sufficiently powerful to compel peaceful behaviour. The trouble with this recommendation is twofold. First, there is no practical way of implementing it. We did not choose to live in the world of independent states which emerged from the Peace of Westphilia in 1648 and we cannot now choose not to live in it. Though the international system is constantly changing, for all practical purposes it is a given, something we have to accept as a fact of life. We are where we are, and whatever conditions of peace we may recommend must take that into account. The second reason for skepticism about the 'world government' solution to the problem of war is that even if we achieved it we might not like it. World government might turn out to be world dictatorshipand inter-state wars might simply become civil wars.

Those who regard the ungoverned international system as the root cause of war often compare it with Hobbesian anarchy; but in reality the society of states bears little resemblance to Hobbes' 'state of nature'. Although it is not an integrated society comparable to domestic society, it is neither chaotic, disorderly, nor wholly unpredictable, and states do not live in conditions of permanent terror. International society is a regulated, rule governed environment in which states can build upon their common interests, and in which international organizations, customs, habits, mores and laws built up over hundreds of years moderate and order their behaviour. Of course, no one would claim that the world of sovereign states is the best of all worlds; it may not even be the best of all possible worlds; but it is better 
than some imaginable alternatives - even better, perhaps, then world government and we ought not to try to jettison it without being very sure that what succeeds it will be an improvement.

\section{Human Nature Explanations of War}

There is widespread agreement that one of the things that distinguishes human beings from animals if that most of their behaviour is learned rather than instinctive. No one knows what the relative percentages are and there is an ongoing vigorous debate about the relative importance of 'nature' versus 'nurture' or 'heredity versus environment' as determinants of human behaviour. Inevitably this debate has prompted the central question of whether war is an example of 'innate' or 'learned' behaviour. If it is innate then we must accept it since in any reasonable timescale biological evolution is too slow to modify it. However, if it is learned then it can be unlearned and there is hope for us all. Liberal thinkers prefer to emphasize the importance of 'nurture' and are naturally attracted to the idea that aggression and war can be tamed. Conservative thinkers tend to throw their weight behind 'nature' and are therefore skeptical about the possibilities of ridding the world of war.

Though they are disposed to minimize its significance, even committed liberals admit that there is a genetic, instinctive element in human behaviour. We do not start with clean slates on which life's experiences are written to make us what we are. We come with genetic baggage, biologically programmed, with built in drives and instincts, one of which, it is argued, is a predilection for aggression and violence. In a celebrated exchange of letters in 1932both Einstein and Freud agreed that the roots of war were to be found in an elemental instinct for aggression and 
destruction. Einstein thought that 'man has in him an active instinct for hatred and destruction', and Freud believed he had identified a 'death instinct' which manifested itself in homicide and suicide.(Freud: 1932) In the 1960s ethological and socio-biological research brought new life to 'instinct' theories of aggression.

Konrad Lorenz argued, largely on the basis of his observations of the behaviour of birds and fish, that an aggressive instinct is embedded in the genetic makeup of all animals (including man), and that historically this instinct has been a prerequisite for survival.(1976) Robert Ardrey, in 'The Territorial Imperative' reached a similar conclusion and suggested a 'territorial' instinct to run alongside Lorenz's four instincts - hunger, fear, sex and aggression.(1966) Edward Wilson in 'On Human Nature' noted that human beings are disposed to react with unreasoning hatred to perceived threats to their safety and possessions, and he argued that "we tend to fear deeply the actions of strangers and to solve conflict by aggression".(1978: 119)

Although Richard Dawkins in his book 'The Selfish Gene' has shifted the level of analysis from the individual to the genes which help make him what he is, he too is under no illusions about human nature. His argument is that "a predominant quality to be expected in a successful gene is ruthless selfishness. This gene selfishnesswill usually give rise to selfishness in individual behaviour".(1976:2) "Much as we might wish to believe otherwise, universal love and welfare of the species as a whole are concepts which simply do not make evolutionary sense".(1976: 2-3) This analysis leads Dawkins to the bleak conclusion that "if you wish... to build a society in which individuals cooperate generously and unselfishly towards a common good, you can expect little help from biological nature".(1976: 3) 
The 'human nature' explanation of war is a persuasive one, but at least two points need to be make about it. First, we need to ask whether the evidence produced by the study of animals is really relevant to the behaviour or human beings. The animal behaviourists say it is because man is simply a higher animal, connected to the rest of the animal kingdom by evolution. To deny that human beings have instincts in the same way that animals do is to deny the almost universally accepted principle of evolution which links all life on the planet. Even so, we cannot help wondering whether the kind of 'cross species' generalization engaged in by biologists is valid. After all, human beings are very different from animals. They are more intelligent; they have a moral sense; they reflect about what they do; they plan ahead. Some would claim that these differences are so important that to all intents and purposes they lift man out of the animal world and reduce his instincts to no more than vestigial significance. A second point worth making about 'instinct' and 'human nature' explanations of war is one which Kenneth Waltz makes in his very influential book 'Man, The State and War'. Waltz admits that arguing that human nature causes war is not very helpful since if human nature causes war then, by the same token, it also causes everything else that human beings do. In his words, 'human nature may in some sense have been the cause of war in 1914, but by the same token it was the cause of peace in 1910'.(1959: 28) In other words, human nature provides no more of an explanation for war than it does of any other kind of human activity.

\section{'Frustration' Explanations of War}

Naturally, given their interests, biologists have concentrated their attention on 'instinctive' rather than 'learned' behaviour, but social psychologists, while still 
locating war in 'man', have offeredexplanations for its occurrence which rely less on instinct and more on socially programmed human behaviour. Typically, they argue that aggression is a result of frustration. When individuals find themselves thwarted in the achievement of their desires, goals and objectives, they experience frustration which causes pent-up resentment which has to find an outlet - and this frequently takes the form of aggressive behaviour which, in tum, has a cathartic effect of releasing tension and making those who engage in it feel better. Usually aggression is leveled at those who cause the frustration, but sometimes it is vented against innocents who become scapegoats. This psychological process of transferring aggression to a secondary group is called 'displacement'. Sometimes individuals project their frustrated desires and ambitions on to the group or collective, be it tribe or state, to which they belong. In the words of R. Niebuhr, "the man in the street, with his lust for power and prestige thwarted by his own limitations and the necessities of social life, projects his ego upon his nation and indulges his anarchic lusts vicariously". (1932: 93)

There is a sense in which the 'Frustration-Aggression' hypothesis, which emphasizes the connection between violence and the failure of human beings to achieve their objectives, is somewhat more optimistic than 'instinct' theories of aggression because, though some degree of frustration in life is unavoidable, it may be possible either to channel aggression into harmless activities like sport (psychologists call this sublimation), or it may be possible to organize society in ways which minimize frustrations (sociologists call this social engineering). 


\section{'Misperception' Explanations of War}

Accepting that wars cannot occur unless statesmen decide to wage them, there are many who believe that those decisions are often the result of misperception, misunderstanding, miscalculation and errors of judgment. Essentially, those who think this way regard wars as 'mistakes', the tragic consequences of failing to appreciate things as they are. This being the case, they are caused more by human frailty or fallibility rather than malice. Robert Jervis, building on the ideas of Kenneth Boulding,(1956)has contributed enormously to our understanding of these psychological causes of war. He makes the point that in order to make sense of the world around us, all of us develop distorted or biased images of reality through which we filter the welter of information which bombards our senses. These 'images', of reality are more important than reality itself when it comes to determining our behaviour; they act as a distorting lens which inhibits our ability to see reality as it is and predispose us to misjudgments and misunderstandings.(1976)

Critically important misperceptions likely to lead to war include mistaken estimates of both enemy intentions and capabilities, inaccurate assessments of the military balance between adversaries, and failures to judge the risks and consequences of war properly. Quite frequently these kinds of misperceptions are made by both sides involved in a conflict. For example, Greg Cashman has argues that in the Gulf War "Saddam Hussein may have perceived a threat from Kuwait's reluctance to allow Iraq to cancel its debts and its unwillingness to pump less oil. He may even have perceived a joint American-Israeli-British conspiracy to deny Iraq sophisticated weaponry.... On the other hand, leaders in virtually all of the Middle East capitals 
Kuwait was invaded. Thus, while Iraqi leaders overestimated the degree of threat to their interests, their opponents underestimated the hostility of Iraq".(1993: 63) But perhaps the most critical misperception of all was Saddam Hussein's failure to anticipate Western resolve and the creation of a powerful military coalition against him.

In the run-up to the Second World War Hitler mistakenly believed that Britain would not fight and Chamberlain mistakenly believed that Germany could be appeased by concessions. Other delusions and misconceptions which contributed to the outbreak of war in 1939 have been identified by AJP Taylor. Mussolini was "deluded" about the strength of Italy; the French believed that France herself was impregnable. Churchill believed that Britain could remain a great power despite the war, and Hitler "supposed that Germany would contend with SovietRussia and the United States for mastery of the world".(Nelson and Olin 1979: 153-4) In Britain hardly anyone expected that German blitzkrieg tactics would bring France down in a matter of weeks, and throughout Europe people grossly overestimated the power of strategicbombing. Given this plethora of misunderstandings, misjudgments and misperceptions, it is easy to argue that statesman stumbled into the Second World War because they were out of touch with reality.

Much the same point can be made about the Falklands war. Misperceptions abounded. Britain seriously misinterpreted Argentinian intentions in respect of invasion, and Argentina badly misjudged Britain's determination to resist. For years the two governmenthad been involved in intermittent negotiations about a possible transfer of sovereignty, and, though little progress had been made, the Conservative 
government could not believe that the Argentine Junta would seize South Georgia before the possibilities of negotiation had been exhausted. What the British government failed to appreciate was the significance of the Malvinas in the Argentinian psyche and the domestic pressures to act which this put on President Galtieri and Dr. Costa Mendez. For its part, the government of Argentina could not believe that at the end of the 20C a Euro-centric, post-colonial Britain was prepared to spill blood for the sake of a barren relic of empire 10,000 miles away.

What is interesting about the misconceptions prevalent both in Germany before the Second World War and in Argentina before the Falklands War is that there is a sense in which both sets of misperceptions were understandable. The signals transmitted by the policy of appeasement may have suggested to Hitler that since he had got away with swallowing the Rhineland in 1936, and Austria and the Sudetanland in 1938, he could probably get away with an aggression against Poland in 1939. In the case of the Falklands the casual pace of British diplomacy and the absence of any serious military capability in the area may have suggested to the Argentinians that Britain was not much interested in the fate of the Falkland Islands and was unlikely to defend them. Perhaps, in both of these cases, it was not so much that signals were

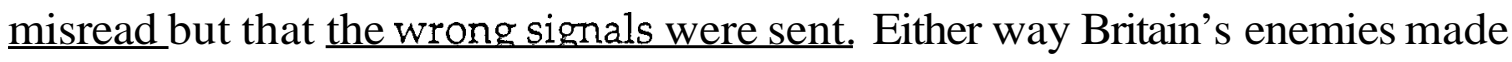
serious miscalculations of her intentions and war resulted.

If wars are caused by misperceptions, misunderstandings and muddled thinking, then conditions of peace include more clear thinking, better communications between countries, and education. This thought lies behind the UNESCO motto 
'Peace Through Understanding', various 'educationfor peace' proposals and the attempts which are frequently made to get potential adversaries round the conference table so that they can better understand each other. The basic idea is that if enemies can be brought to appreciate each other's perspectives the disputes which divide them will dissolve because they will be seen to be either illusory or not sufficiently serious to justify war. Perhaps we can detect in this approach relics of the idea of a natural 'harmony of interests' which would prevail if only misunderstandings were cleared up.

Before we are persuaded by this idea that wars can be eliminated by removing misperceptions and misunderstandings, a word of warning is appropriate. First, it may not be possible to eradicate misperception from human affairsgiven the inherent cognitive weaknesses of the human mind. The need to simplify, the inability to empathize, the tendency to ethnocentrism, the reluctance to relinquish or recognize prejudices - all these familiar human weaknesses may make some degree of misperception inevitable. Herbert Butterfield recognized this point when he identified an 'irreducibledilemma' which lies in the very geometry of human conflict. Butterfield imagined a situation in which two potential enemies, both armed, face each other. Neither harbours any hostile intent but neither can be sure of the intentions of the other. "You cannot enter into the other man's counter fear" and "it is never possible for you to realize or remember properly that sincehe cannot see the inside of your mind, he can never have the same assurance of your intentions that you have".(1952: 21) Butterfield makes the point that the greatest war in history could be caused by statesmen who desperately want peace but whose cognitive limitations lead them to misinterpret each others intentions.(1952: 19). 
(Discerning students will realize that Butterfield's 'ultimate predicament' has, in recent years, surfaced in the literature of Strategic Studies as 'The Security Dilemma').

A second word of warning is appropriate because it has to be recognized that not all wars are caused by misperceptions and misunderstandings even though they may be surrounded by them. Some wars - perhaps most - are rooted in genuine disagreement and conflicting interests, and in these cases discussions between enemies simply promote a better understanding of the disputes which divide them. Indeed, in some situations improved understanding may actually exacerbate the divisions between adversaries. When it was suggested to him that international hatred and suspicion could be reduced by getting nations to understand one another better, Sir Evelyn Baring, British governer in Egypt between 1883

and 1907replied that "the more they understand one another the more they will hate one another".(Waltz 1959:50) Perhaps it can be argued that for most of the 1930s Britain was at peace with Germany precisely because we did not understand Hitler. When, in September 1939, the penny finally dropped the first thing Britain did was to declare war on Germany. 


\section{Conscious and Unconscious Motives for War}

The trouble with all these explanations which locate the causes of war within 'man' is that those leaders and statesmen who actually declare wars would almost certainly offer quite different explanations for their decisions. Hitler, if he had been asked why he attacked Poland on September 1st 1939, is unlikely to have replied that he was acting instinctively, or that he was frustrated or a victim of misperception. He would almost certainly have offered rational, practical reasons to do with the plight of Germans in Danzig and the Polish corridor and the iniquitous way in which the politicians at Versailles had re-drawn the map of Europe to Germany's disadvantage. This discrepancy between the explanations of war offered by practitioners and those suggested by philosophers and scientists suggests that it may be useful to distinguish between conscious and unconscious motives for war.

. Statesmen have a Clausewitzian, 'instrumental', view of war. They regard it as a rational tool for the implementation of policy, a technique which is available for practitioners to use in appropriate circumstance for the pursuit of national interests. In other words, for a statesman war results from a calculated, purposive, conscious decision; but for the philosophers and scientists, trying to look behind the statesman's goal orientated acts, war results from unconscious drives and weaknesses in the human psyche of which practitioners may be unaware but which nevertheless push them towards war.

Those who regard war simply as an instrument of policy, a consequence of rational decisions taken in the national interest, underestimate the pressures and constraints - from public opinion, nationalist sentiment, alliance commitments, the momentum 
of events, etc - which may push politicians towards war despite their reservations. They may also make the mistake of thinking that once the costs and consequences of war have been made clear to politicians they will refrain from it. Norman Angell spent much of his lifepointing out, quite rightly, that 'wars do not pay', that they are not in the national interest and that even the victors are usually losers.(1914) $\mathrm{He}$ thought that once this basic fact had been grasped wars would cease. Sir Norman failed to appreciate two things. First, that wars are not always a matter of rational calculation or 'cost-gain' analysis. Sometimes wars are a kind of madness, explosions of violence far removed from rational policy. Herman Rauschning, for example, argued that the National Socialist Movement in Germany during the 1930s was impelled towards a war of destruction by its own inherent madness.(1939) The second weakness of Angell's analysis is that although he was right to point out the disastrous economic consequences of war, he was probably wrong to conclude that waging war was therefore irrational and not in the national interest. Victors may be losers as a result of the wars which they fight, but refusing to fight may make them even bigger losers in the long run. Britain, a victor in the Second World War, emerged from it permanently weakened, but if Hitler had not been stopped Britain would probably have ended up in an even worse position. Waging war against Germany certainly 'did not pay', but it was still the rational choice of the least disastrous of two disastrous outcomes.

\section{‘Group' Explanations of War}

Though embarked upon by individual human beings, war, by definition, is a group activity. It is waged by human collectives - factions, tribes, nations, states, even perhaps 'civilizations'. This has led some to shift the responsibility for war from 
human beings to the groupings within which they live and to which they owe varyıng degrees of allegience. Those who argue in this way believe that there is nothing much wrong with human beings per se, but they are corrupted by the social structures in which they live. In the words of Nietzsche 'Madness is the exception in individualsbut the rule in groups'. Essentially the argument is that there is something about human collectives which encourages violence.

Perhaps the trouble starts with the sense of difference which we all feel between 'us' and 'them', between those who belong to our collective grouping - be it tribe, state or nation - with whom we empathize and share a 'we' feeling, and other groups with which we cannot identify easily. It is all too easy for a group to slide from recognizing that it is different from other groups to believing that it is superior to them. Hence, this sense of differentiation - what Suganami calls 'discriminatory sociability' (1996:55) - easily leads to group selfishness, inter-group conflict and ultimately war. As R. Neibuhr once observed "altruisticpassion is sluiced into the reservoirs of nationalism with great ease, and made to flow beyond them with great difficulty".(1932: 91)

G. Le Bon was one of the earliest social psychologiststo notice that the behaviour of social groups is different - and usually worse - than the behaviour of the individuals comprising them. He developed the idea of 'crowd psychology', that in a 'crowd' a new entity or collective mind comes into being. He believed that in groups individuals lose their normal restraints, become more suggestible, more emotional and less rational. What is more, groups have reduced feelings of responsibility because the more responsibility is diffused in 'crowds' the less heavily it weighs on 
each individual. Since responsibility is everywhere (and therefore nowhere) blame cannot be allocated specifically and this frees human collectives from normal moral restraints.(1897:41). This thought was neatly captured in the title of R. Neibuhr's classic 'Moral Man and Immoral Societv', and Eric Hoffer, in discussing the appeal of mass movements makes the same point very graphically. "When we lose our individual independence in the corporateness of a mass movement, we find a new freedom - freedom to hate, bully, lie, torture, murder and betray without shame or remorse".(1952: 118)

Human beings have always lived in differentiated groups and it is unlikely that this will change in the foreseeable future. The interesting question is whether some groups are more war prone than others. In the context of inter-state wars, for example, can it be argued that capitalist states are more warlike than socialist states or vice versa? There is no clear answer to that question. Can we argue that democratic states are more peace-loving than authoritarian states? Again there is no clear answer. The historical evidence suggests that "democracies fight as often as do other types of states",(Kegley and Wittkopf 1997:358) and, in recent years, as wars in the Gulf and the Former Yugoslavia have shown, democratic states have demonstrated some enthusiasm for wars of intervention in support of human rights. This current fashion for waging wars in support of liberal values does not augur well for a peaceful world.

However, various observes have noted that democracies seldom, if ever, fight each other. Michael Doyle, for example, has argued that liberal states are more peacefully inclined towards each other because their governments are more constrained by 
democraticinstitutions, because they share the same democratic values and because commercial interdependencebetween liberal states gives them a vested interest in peace. (1983 and 1986) If Doyle and those who share his views are right, one of the conditions of peace is the spread of democracy - a trend which has gathered pace particularly since the end of the Cold War. For the first time ever, almost half of the world's governments are now democratic. However, the thesis that the spread of democracy will promote peace is plausible but no more than that, and it would be unwise to accept it uncritically.

\section{Wars 'within' and bevond' States}

Whether its decline is connected to the spread of democracy or not, inter-state violence now seems less of a problem that it used to. But intra-state war, particularly ethnic war - has become much more of a problem, and S.P. Huntington has alerted us to the prospect of war between 'civilizations'. Ethnic groups and tribes, once contained, even suppressed, within states have suddenly erupted on to the political scene, reviving ancient racial hatreds and creating mayhem in countries as diverse as Yugoslavia, Somalia and Indonesia. What is particularly horrifying about ethnic wars is that people are brutalized and killed not because of anything they have done, not even because of their politics, but simply because of who thev are. That is what is so terrible about the persecution of the Tutsis in Rwanda, the Tamils in Sri Lanka, the Kurds in Iraq, the Muslims in Bosnia, and the Albanians in Kosovo. Ethnic wars are quite different from Clausewitzian politically motivated conflicts where the belligerents disagree about something and seek to resolve their disagreement by inter-state war - an activity conducted according to rules, both moral and legal. It may be going to far to describe such wars as rational and 
civilized but there is a grain of sense in the thought. Ethnic wars are quite different. They are not about the pursuit of interests as normally understood. They are about malevolence and they are unrestrained by rules either legal or moral. 'Ethnic cleansing', like 'the final solution', is surely one of the most sinister phrases to enter the political vocabulary of the $20^{\prime}$ Century. ${ }^{(1)}$

One of the reasons for the recent upsurge of ethnic violence is surely to be found in the failure of modern states to hold the ring between warring factions. It is ironic that authoritarian governments, so frequently blamed for inter-state wars, were instrumental in preventing civil wars in countries like Yugoslavia and the Soviet Union. Hobbes' Leviathian may have its attractions if the alternative is genocidal violence. If the thousands of ethnic groups which exist in the world can no longer be contained within nation states then we face the break-up of international society into a myriad of micro groups. It has to be said that the consequence of 'Balkanization' on this scale are incalculable and unlikely to lead to a more peaceful world.

Wars between states and wars between nations and tribes within states are depressingly familiar, but the idea that future conflicts of global politics will occur between civilizations is a new one. In a provocative and influential article in Foreign Affairs S.P. Huntington has predicted that the fundamental source of conflict in the years ahead will be cultural. "The fault lines between civilizations will be the battle lines of the future" (1993a: 22). In Europe, for example, as the ideological divisions of the Cold War disappeared, the age old cultural divisions between Western Christendom on the one hand and Orthodox Christianity and Islam on the other 
reappeared . As W. Wallace has suggested, "the most significant dividing line in Europe may well be the eastern boundary of Western Christianity in the year $1500^{\prime \prime 2}$. This cultural fault weaves its way from the Balkans to the Mediterranean and conflict along it is to be expected.

Huntington argues that a civilization is "the highest cultural grouping of people and the broadest level of cultural identity people have"(1993a: 24) He has identified eight civilizations -Western, Japanese, African, Latin American, Confucian, Hindu, Islamic and Slavic Orthodox - all of which differ from each other in terms of their respective attitudes to democracy, free markets, liberalism, church-state relations and international intervention. The differences between civilizations on these issues is deeper than those between states and ideologies and in consequence consensus and agreement is difficult to achieve. Among the reasons for thinking intercivilizational conflict is likely is that in many parts of the world 'Western' values are being challenged, there is a resurgence of religion and fundamentalism which has widened the gulf between peoples, and the 'communications revolution' has made people more aware of the differences which divide them.

\section{'Necessarv' and 'Sufficient' Causes of War}

Various writers have found it useful to distinguish between 'necessary' and 'sufficient' causes of war. ${ }^{(3)}$ A 'necessary' condition of war is one which must be present if war is to occur. If war cannot break out without that condition existing then it is necessary condition. The existence of armaments is a necessary condition of war because without them no war could be fought. For wars to occur it is also necessary for human beings to be organized in discrete collectives - states, tribes, 
ethnic groups, nations, factions etc. Equally, it is a necessary condition of war that there be no effective mechanism for preventing it. An effective world government for example, would make it impossible for inter-state wars to occur, and an all powerful state government would make it impossible for civil wars to occur. Thus, the absence of these mechanisms is a necessary condition of war.

There is an element of tautology in the above analysis in the sense that if we define war as organized violence between groups then it is obvious that wars cannot occur if human beings are not organized in groups which have the capacity for organized violence, and it is equally obvious that wars cannot occur if there is a mechanism which prevents them. More controversially, as we have been ( $p p$ ), it has been suggested that one of the necessary conditions of war is that at least one of the parties to it must have a non-democratic government.

A 'sufficient' cause of war is one that, if present, guarantees the occurrence of war. $A$ is a sufficient cause of B if B always occurs whenever A exists. If two states hate each other so much that neither can tolerate the independent existence of the other then that is a sufficient cause of war which makes was between them inevitable. But it is not a necessary condition of war since many wars occur between states which do not share that degree of hatred and are perfectly content with each others' continued existence as a independent states in international society. Clearly, a cause of war can be sufficient without being necessary, and the converse of this is also true - a cause can be necessary without being sufficient. For example, the existence of weapons is a necessary condition of war, but as we saw on p.... it is not a sufficient cause of war since even the existence of high levels of armament does not always lead to war. 
The categories' necessary' and 'sufficient' do not cover all the possible causes of war. We must not fall into the trap of thinking that the causes of war must be either necessary or sufficient because there are many causes which are neither necessary nor sufficient. For example, the desire of statesmen to annex territory belonging to neighbouring states is a common cause of war but it is neither a necessary nor a sufficient cause. It is not a necessary cause because many wars are fought for reasons which have nothing to do with territory, and it not a sufficient cause because the desire to annex territory may not be acted upon - perhaps because of deterrence.

\section{Conclusion}

There is no shortage of 'cures' for the 'disease' of war. Some are bizarre - like, for example, Linus Pauling's suggestion that since wars are caused by a vitamin deficiency we can eat our way out of aggression by swallowing the appropriate tablets. Others- like calls to change human nature, to reconstruct the state system, to equitably redistribute the world's wealth, to abolish armaments, to 're-educate' mankind, etc, - follow with faultless logic from the various causes of war which scholars have identified; but since there is no prospect of implementing them in the foreseeable future there is sense in which they are not solutions at all. Henry IV's reputed comment on an equally impractical proposal for peace is still appropriate, 'It is perfect', the king said, 'Perfect. I see no single flaw in it save one, namely, that no earthly prince would ever agree to it',. Hedley Bull has rightly condemned such solutions as "a corruption of thinking about international relations and a distraction from its proper concerns"(1961: 26-27) 
We have to begin by recognizing the limits of what is possible. Hopefully, we can then edge our way forward by improving our techniques of diplomacy, communication, crisis avoidance and crisis managements; by developing a conc pt of enlightened self interest which is sensitive to the interests of others; by extending the scope of international law and building on existing moral constraints; by learning how to manage military power through responsible civil-military relations and sophisticated measures of arms control; by strengthening cooperation through internationalorganizations and world trade. These are not spectacular, radical, or foolproof solutions to the problem of war, but they are practical steps which offer the possibility if not of abolishing war, at least of reducing its frequency, and perhaps also of limiting its destructiveness.

Even if war could be abolished we need to remember that peace is not a panacea in which all human antagonisms are resolved. Peace is simply the absence of war, not the absence of conflict, and, as the Cold War demonstrated, it is just as possible to wage peace as it is to wage war. Though 'peace' and 'war' are usually regarded as opposites there is a sense in which both are aspects of the same thing - the conflict which is endemic in all social life. War is simply a special kind of conflict which differs from peace only by its violence nature.

The fact that peace is not a panacea explains why, when confronted with the stark choice of peace or war, leaders sometimes choose war. Somekinds of peace - under dictatorshipsfor example - may be worse than some kinds of war. In other words, although almost every one wants peace, almost no one (apart from strict pacifists) wants only peace or peace at any price. If it were otherwise the problem of war would disappear since as a last resort states can always avoid war by surrendering. 
Capitulation might bring peace but it would almost certainly entail the loss of some of those other things that states want - like independence, justice, prosperity and freedom, and when it comes to the crunch states may think that these are worth fighting for.

Ideally, of course, what people want is a worldwide just peace. Unfortunately, this is an unattainable dream. It would require agreement on whose justice is to prevail; it would require a fundamental redistribution of the worlds' wealth from the Haves to the Have-nots; it would require religious and political movements - Muslins, Christians, Jews, Hindus, Communists, Capitalists - to tolerate each other; it would require an end to cultural imperialism and an agreement that differing cultural values are equally valid. It would probably require the disappearance of borders and differentiated societies with their 'them' and 'us' mentalities. In short, it would require human beings to behave in ways in which they have never behaved. It would, to quote one scholar, (4) "require an animal that is not what human beings are".

Since 'Justice' and 'peace' do not go together statesmen will have to continue choosing between them. The pursuit of justice may require them to wage war, and the pursuit of peace may require them to put up with injustice. Arguably, during the Cold War years, Western politicians, by abandoning Eastern Europe to its fate under Communism, thought probably rightly that peace was more important than justice. Since the end of the Cold War they have tended to put justice before peace witness the upsurge of violence caused by wars of intervention in support of human rights and democratic values. The critical question facing us now is whether, in 
juggling the priorities of peace and justice, we have got the balance right, or whether our current enthusiasm for Western values and human rights implies an ever so slightly casual attitude to the problem of war. Perhaps, in the interests of peace, there is something to be said for the Realist policy of fighting 'necessarv' rather than 'just' wars. 


\section{Notes}

1. For a comprehensive and brilliant account of ethnic conflict up to 1985 see Horowitz, D.L. (1985)Ethnic Groups in Conflict_(Berkeley, Los Angles, London: University of California Press.

2. Quoted by Huntington, S.P. (1993a), The Clash of Civilizations, Foreign Affairs $_{\mathbf{L}} \mathbf{7 3}$ (3) p.30

3. See, for example, G. Quester, 'War and Peace: Necessary and Sufficient Conditions' in Matthews, R.O., Rubinoff, A.G., Stein, J.G. (1984)International Conflict and Conflict Management (Scarborough Ontario: Prentice-Hall)pp4454.

4. This comment by Professor Claude Phillips is quoted by Shaw, R.P.and Wong, Y. (1989) Genetic Seeds ofWarfare :Evolution, Nationalism and Patriotism (London: Unwin Hyman) p.207 


\section{$\underline{\text { References }}$}

Angell, N. (1914), The Grent Illusion (London:Heinemann).

Ardrey, R. (1966)m The Territorial Imperative (New York: Atheneum).

Boulding, K.(1956), The Image (Ann Arbor: University of Michigan Press).

Bull, H. (1961), The Control of the Arms Race (London: Wiedenfeld and Nicholson).

Butterfield, H. (1952), History and Human Relations (London: Collins).

Carr, E.H. (1942), Conditions of Pence (London: Macmillan \& Co.)

Cashman, G. (1993), What Causes War?. An Introduction to Theories of Internation

Conflict (New York: Lexington Books).

Dawkins, R. (1976)The Selfish Gene (Oxford: Oxford University Press).

Doyle, M.W. (1983), 'Kant Liberal Legacies and Foreign Affairs', Philosophy and Public Affairs 12.

(1986) 'Liberalismand World Politics', American Political Science Review, 80. 
Freud, S. (1932), 'Why War?' in Bramson, L. and Geothals, G.W. (1968) War: Studies fromPsychology Sociology Anthropology (New York and London: Basic Books).

Gowans, A.L. (1914), Selections fromTreitschke's Lectures on Politics (London and Glasgow: Gowans and Gray).

Hoffer, E. (1952), The True Believer: Thoughts on the Nature of Mass Movements (London:Secker and Warburg).

Huntington, S. (1993a), The Clash of Civilizations, Foreign Affairs, 72 (3). (1993b), Response: If not Civilizations, What? Paradigms of the PostCold War World, Foreign Affairs, 72 (5).

Jervis, R. (1976), Perception and Misperception in International Politics (Princeton N.J: Princeton University Press. (1983), 'Perception and Misperception: The Spiral of International Insecurity' in

Olson, W.C., Mclellan, D.S. and Sondermann, F.A. (1983). The Theory and Practice of International Relations ( $6^{\text {th }}$ Ed.) (Englewood Cliffs N.J. :Prentice Hall).

Le Bon, G. (1897) The Crowd :A Study of the Popular Mind $\left(2^{\text {nd }}\right.$ Ed.) (London :Fisher Unwin).

Lorenz, K. (1976), On Agression (New York Bantam). 
Nelson, K.L. and Olin, S.C. Jr. (1979), Why War:Ideology, Theory, and History (Berkely and Los Angeles: University of California Press).

Neibuhr, R. (1932), Moral Man and Immoral Society :A Study in Ethics and Politics (New

York and London: Charles Scribner's sons).

Rauschning, H. (1939), Germany's Revolution of Destruction, trans. E.W. Dickes (London:

Heinemann).

Suganami, H. (1996), On the Causes of War (Oxford:Clarendon Press).

Thompson, K. (1960)Moral Purpose in Foreign Policy :Realities and Illusions' Social Research, 27 (3).

Waltz, K. (1959), Man, the State and War (New York: Columbia University Press).

Wilson, E.O. (1978), On Human Nature (Cambridge Mass: Harvard University Press). 


\section{Discussion Ouestions}

1. Which of the distinctions in Box I do you think is most useful for analyzing the causes of war?

2. Do you think the spread of democracy will solve the problem of war?

3. To which would you allocate priority, the pursuit of peace or the pursuit of justice?

3. Is aggressive behaviour instinctive or learned?

5. How convincing is the argument that wars are a result of misjudgment and misperceptions?

6. Is war inevitable?

7. Do arms races cause wars?

8. Is war an instrument of policy or a n outburst of irrationality? 


\section{BOX I}

Five distinctions which may help claify our thoughts about the causes of war.

1. Between 'instinctive' and 'learned' behaviour

2. Between 'immediate' and underlying' causes.

3. Between 'efficient' and 'permissive' causes.

4. Between 'conscious' and 'unconscious motives for ear.

5. Between 'necessary' and 'sufficient' causes. 


\section{Rousseau's 'stag:hunt' analogy}

Rousseau imagines a situation in which several solitary and hungry hunters existing in 'a state of nature' where there is neither law, morality nor government, happen to come together. Each of them recognizes that his hunger could be satisfied by a share of a stag, and so they 'agree' to cooperate to catch one. In Rousseau's words "If a deer was to be taken, everyone saw that in order to succeed, he must abide faithfully by his post; but if a hare happened to come within reach of any of them, it is not to be doubted that he pursued it without scruple, and, having seized his prey, cared very little if by so doing he caused his companions to miss theirs"

J.J. Rousseau, 'A Discourse on the Origin of Inequality', in Cole G.D.H. 1993edition, The Social Contract and Discourses (London:J.M. Dent) p.87

The point of the story is that in conditions of anarchy the hunter who grabbed the hare could not feel confident that one of his fellow hunters would not do likewise if presented with the same opportunity, in which case he would go hungry. Given this predicament the sensible thing to do is to behave selfishly and seize the hare. 
BOX III

Some statistics about war. 


\title{
Strategy in the Contemporary World
}

\section{Land Power: Theory and Practice}

\author{
Stephen Biddle \\ Department of Political Science \\ 325 Hamilton Hall \\ University of North Carolina \\ Chapel Hill, NC 27599-3265 \\ USA \\ 919-962-8286 office \\ 919-383-3336home \\ 919-962-0432 fax \\ sbiddle@unc.edu
}




\section{Scope}

$20^{\text {th }}$ and early $21^{\text {st }}$ century "major" continental warfare, e.g.:

- World Wars I and II

- Korea

- Mideast wars of 1956, 1967, 1973, 1982 (Bekaa Valley)

- India-Pakistan wars of 1965, 1971

- Iran-Iraq War

- Gulf War of 1991

- Ethiopian-Eritrean War of 2000

Focus on operational and tactical levels of war;

Some attention to theater strategy

Little explicit discussion of grand strategy

Emphasis on effects of technological change; interaction between technology, tactics, and doctrine 


\section{Outline}

I. The Problem: Coping with the Storm of Steel

II. A Solution: Evolution of Modern Operations and Tactics

III. Results: Increasing Variance in Combat Outcomes

IV. The Future: Continued Divergence Between Skilled and Unskilled Performance 


\section{The Problem: Coping with the Storm of Steel}

Industrialization brings many important changes, e.g.:

- Increased size of armies

- Increased strategic mobility (railroads)

- Improved long-range communications (telegraph)

- Eventually, increased tactical/operational mobility (internal combustion engine)

Perhaps most important is radical increase in firepower

- Breachloading magazine rifle

- Machinegun

- Breachloading, recoil-absorbing, steel artillery

- Industrial-scale production of ammunition and weapons

Though discussions of effects often focus on pre-World War I era, firepower's range and net lethality have continued a pattern of progressive, rapid growth ever since

- Artillery range increased by factor of 10 from 1900-2000

- Ground-attack aircraft range, payload increased by more than factor of 10 from 1900-2000

- Target acquisition for deep fires improved from primitive sound/flash ranging, early aerial recce of 191518 to radio DF, accurate real-time aerial spotting by mid-1940s to SLARs, FLIRs, ELINT (etc) by 1990s

- Gun-armor race increasingly favors gun: penetration range for primary U.S. tank vs primary opponent, e.g., increased from $<500 \mathrm{~m}$ in 1945 to $1000 \mathrm{~m}$ by 1970 to $>3000 \mathrm{~m}$ by 1990

- PGMs radically increased hit probabilities for exposed targets after ca. 1970

Defines key problem of modern land warfare: how to cope with the resulting "storm of steel" (per Ernst Junger) 


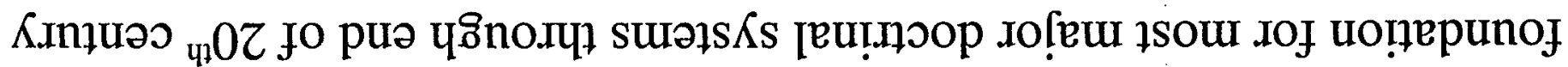
[en]dәวuоo pəp!̣

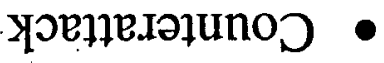

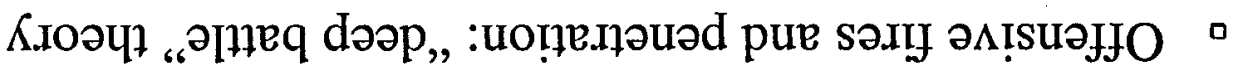

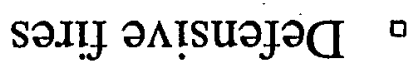

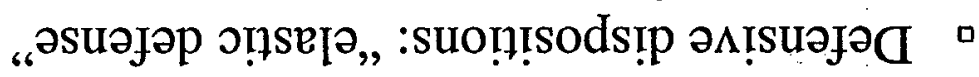

$$
\begin{aligned}
& \text { ч1dә्व • } \\
& \text { uo!̣eł! } \\
& \text { :suo!̣e.IədO }
\end{aligned}
$$

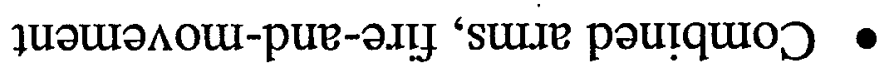

$$
\begin{aligned}
& \text { uotssəIddnS • }
\end{aligned}
$$

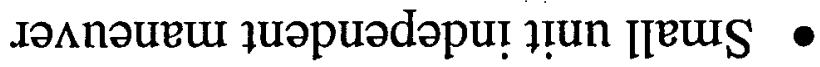

$$
\begin{aligned}
& \text { uoț.ıds! • }
\end{aligned}
$$

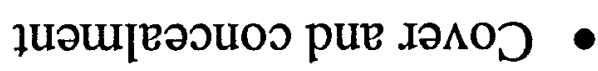

$$
\begin{aligned}
& \text { :SO!̣ORL }
\end{aligned}
$$

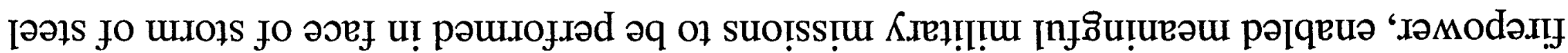

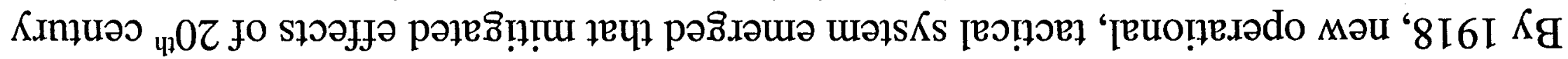

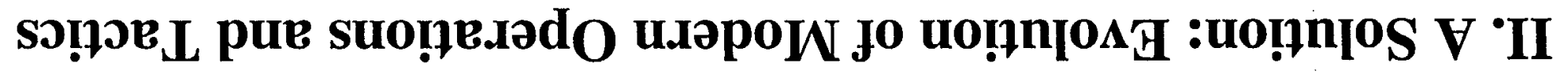




\section{Results: Increasing Variance in Combat Outcomes}

"Modern system" operations and tactics are effective, but highly complex, very difficult to implement

- Individual, custom decision making by each of thousands of jr. leaders

- Tight coordination between widely separated, moving units and multiple commanders

- Weapon types with widely varying mobility, vulnerability must be kept together over changing terrain, varying opposition

- Weapon types with widely varying maintenance, support, employment demands must be commanded by individual,jr., leaders

- Delicate balancing acts at operational level

- Unpopular political, organizational side effects:

- Requires high military proficiency - difficult to square with short-service conscription systems, can heighten civil-military conflict

- Requires autonomy for jr. and sr. leaders - difficult for repressive regimes to tolerate

- Elastic defenses yield territory early - problematic where border territory is economically or politically important

- Elastic defense demands disproportionate sacrifices from forward zone garrisons

Consequence: some states can, but many cannot, implement properly 


\section{Results: Increasing Variance in Combat Outcomes (cont'd)}

As weapons become more lethal, consequences of failure to implement "modern system" become more severe:

- Lethality grows over time vs. targets in all postures, but lethality growth rate much slower vs. covered, concealed, dispersed targets than vs. massed, exposed ones

- Faster, longer range weapons make deep exploitation increasingly decisive when possible, but very difficult to achieve vs. deep, elastic defenses

Result is growing gap between armies that can, and those that cannot, implement "modern system" methods

- Armies that can: largely shielded from worst effects of increasing lethality, range, speed, of hostile weapons

- Armies that cannot: fully exposed to increasing lethality, range, speed, of hostile weapons

Where both sides implement "modern system" methods, tendency is toward extended war of material production - neither side able to force quick, decisive outcomes

Where one side does, other does not, result is increasingly one-sided as century unfolds:

Technology as a wedge, driving apart the real military capability of skilled and unskilled armies, but with much lesser effects against equally skilled opponents 


\section{The Future: \\ Continued Divergence Between Skilled and Unskilled Performance}

Will an "RMA" change the pattern of $20^{\text {th }}$ century land warfare?

No: ongoing technological change will continue, even accellerate, longstanding trend toward divergence between skilled and unskilled performance

- New recce, surveillance, target acquisition, weapon guidance technologies remain far more effective vs. massed, exposed targets than vs. dispersed, concealed, intermingled ones

- Unlikely to change soon: increase in weapon lethality vs. dispersed, concealed, intermingled targets likely to remain slow for near-to-mid term

- Lethality gap thus likely to continue to grow; gap between real capability of armies that can and those that cannot implement modern-system methods for exploiting cover, concealment, and dispersion likely to increase

- Adequate exposure reduction becomes harder, more complex as weapon range increases and as multispectral sensing becomes more sophisticated and more widespread

- Thus adequate force employment becomes at once more important and harder - but still achievable for skilled militaries

Technology's effects are important, but have varied dramatically with targets' tactics, doctrine, and skills throughout 20th century - and will continue to do so in early 2 1st 
19September 2000

First Draft

8500 words

\section{BEYOND THE SEA:}

\section{NAVAL STRATEGY FOR A WORLD WITHOUT NAVIES}

by Sam J. Tangredi*

Prepared for Strategy in the Contemporary World Workshop

Naval Postgraduate School, Monterey, CA

19-21 September 2000

- The views expressed are solely those of the author and do not represent the official views of the United States Navy or any other agency of the United States government. 
19 September 2000

\title{
BEYOND THE SEA:
}

\section{NAVAL, STRATEGY FOR A WORLD WITHOUT NAVIES}

\author{
by Sam J. Tangredi*
}

In the contemporary world, there are no navies.

On the surface, that might seem an over-dramatic statement; one must concede that there indeed is a navy. The United States Navy is now the only, and possibly the last global navy. In effect, it has become the world's navy.

This situation is both a reflection of resource capabilities and the result of victory. The specifics of both will be discussed later, but certain implications need to be identified up front - implications that can be expressed in the form of questions. If, in fact, there is but one navy, does naval warfare - traditionally defined —still exist? Have maritime operations become but a spoke in the purple umbrella of joint military operations, without its own logic and grammar? And what has become of sea power, the near legendary capacity for transoceanic power for which all the great nations of the world once thirsted? If decisive war at sea between opposing fleets is a near impossibility, of what actual use is a navy? In the contemporary world of globalization, post-industrialization,instant communications, and weapons of mass destruction(WMD) proliferation, is there any point of discussing naval strategy at all?

To answer these questions requires a blend of theory, historical observations, and assessment of defense decision-making--all tinged with what could be facetiously

\footnotetext{
- For the purpose of 'value explicitness,' it should be acknowledged that the author is an active duty officer with a natural bias towards things naval. However, the views expressed are solely those of the author and
} 
referred to as a 'deconstructionist' approach.' The first step in this chapter is to examine exactly what is $\boldsymbol{a}$ navy. This is followed by an evaluation of the phenomenon that some are calling a "revolution in naval affairs." The evaluation, in turn, requires a look at the relationship of sea power to land power (and other forms of military power) in the $21^{\text {st }}$ century. Such a $21^{\text {st }}$ century intellectual voyage also requires some discussion of the impact of globalization, the topic du jour. Finally, the chapter identifies some of the emerging concepts of naval operations that are on the cutting-edge of the U.S. Navy's continuing force structure debates. The common theme is that the role of the $21^{\text {st }}$ century navy is no longer tied to the physical ocean, but now lies 'beyond the sea."

\section{What is a Navy?}

The answer to the above question is dependent on the difference between a navy as an officially defined organization and naval operations as a military function. From the narrow perspective of organization, the obvious, but only partially correct answer is that a navy is a military force that operates primarily at sea.

From this point of view, it easy to categorize naval warfare as but one comer of overall joint military operations: "the army fights on land, the air force fights in the air, and the navy fights at sea.' Of course, even this simplistic formula is made more complex by the fact that naval forces of the United States also consist of the United States Marine Corps, as well as sea-based strike aviation and a host of other land-oriented

do not represent the official views of the United States Navy or any other agency of the United States government.

${ }^{1}$ This is not meant to be actual deconstructionism, which has been transformed from a method of literary criticism to a philosophy that rejects absolute tnth. Rather, it is in keeping with the fuzzier definition of 'a challenge to the established meaning of a term.'

${ }^{2}$ The phrase 'beyond the sea' was used as the title of a proposed strategic vision, developed by members of the Strategy and Concepts Branch of the Office of the Chief of Naval Operations, that was never actually 
functions. Yet, it is still somehow comforting for a 'purple-suited' joint planner to be able to divide up the battlefield into such equal pieces of the 'jointness' pie. It is an image in sync with the reigning ideology of the Department of Defense: jointness defined as the relative equivalence of all missions and services.

In this image, aircraft carriers are simply alternative air fields; naval aviation consists of just more sorties in the Air Tasking Order (ATO); surface combatants are floating armored vehicles with missile batteries; submarines are stealthy intelligence platforms that can get closer to the target than satellites; and amphibious ships are-well-something the Army doesn't want to buy. Conceptually, naval warfare and land operations are the same, only wetter. Naval combat ends at the water's edge (or a little bit beyond); land combat starts there.

But there is a significant difference between the functioning of navies and landbased military forces. Unlike other forms of military power, naval forces are primarily and uniquely designed to control the flow of contact through the dominant mediums of human interaction and exchange, rather than directly control territory or areas of human habitation.

In short, armies are designed to control territory; navies are designed to control access.

Fighting in a multiplicity of mediums--the undersea depths, the surface of the sea, the air, littoral regions, space, and the infosphere - navies contest for the control of interactions, rather than populations. The classical naval struggle for 'sea control' is for dominance of oceans--which are, in fact, mediums that humans use, but can not 
permanently inhabit. Once dominated, these oceans can provide the access to the areas where humans live as well as control links between these areas and the rest of the globe.

The difference between this concept and the organizationalview is more than semantics. To occupy territory requires one to close with the enemy, defeat them, and garrison their state (to a lessor or greater extent). This, of course, is only a partial victory and results in temporary peace. Complete victory (and a longer peace) involves getting the enemy to adopt your own political values, thereby making politically-motivated conflict unlikely.

Controlling access, however, involves the cutting off of the enemy state from the world. The fruits of being a nation-state - formalized trade relationships, interactions with other ideas and cultures, even the underlying motivation for nationalism itself-can not exist without interaction with the rest of the international system. These interactions require access to the fluid mediums of communications and exchange. Such access can be checked by physical blockades, interdiction, actual combat or 'cyberwar,' or intimidated by nearby military presence.

Due to the earth's geography, the physical properties of gravity, and the lessphysical restraints of common international law, all of these things are most easily be done by military forces (actually naval forces) located within the fluid mediums of exchange. To cut off access does not necessarily require closing with enemy or the occupying their territory- - at least not for a sea power nation. The $17^{\text {th }}$-century political philosopher Sir Francis Bacon got it right when he said that a sea power could "take as much or as little of war as it desires." 
Of course, readers with a critical eye could point out that an 'state of accessdenial' in which the machinations of an aggressor are merely blocked does not appear to lead to long-term peace any more than occupation? A timely illustration is the brooding presence of Saddam Hussein, apparently unconverted by sanctions or periodic air strikes on his military. However, this can be countered by the one huge example of an 'access denial' strategy that really worked: the containment of the Soviet Union.

As stated, armies are designed to control territory; navies are designed to control access. $A$ navy $i$ s that portion of military forces that operates in the mediums which humans use for communications, transportation and exchange but cannot normally inhabit. Its prime purpose is to ensure or deny access. Its effect on territories and population is generally indirect, however, the freedom of operation that the law of the sea permits in the international commons of the ocean provides for independent and direct effects in the littoral regions to the ever-increasing range that technology allows naval weapons (which includes sea-based aviation) to reach.

Under this 'deconstructionist' definition, organizations wearing other uniforms, but operating within the mediums of communications and exchange, can be seen as naval in function or tone. ${ }^{4}$ This obvious contradicts the organizationaldefinition and

\footnotetext{
${ }^{3}$ The term 'access denial' has come to be used by some as synonymous with 'anti-access' strategies, methods which regional powers might use to prevent U.S. power projection forces from entering their region. The meaning of 'area denial' in this chapter reverses the emphasis and refers to the U.S. Navy's ability to cut off the access of a potential opponentto the rest of the world. Discussions of anti-access strategies can be found in Thomas G. Mahnken, "America's Next War," The Washineton Ouarterly 16:3 (Summer 1993), pp. 171-184;Mahnken, "Deny U.S. Access?" U.S. Naval Institute Proceedings 124:9 (September 1998), pp. 36-39; CAPT Sam J. Tangredi, USN, "The Fall \& Rise of Naval Forward Presence," United States Naval Institute Proceedines 126/5 (May 2000), pp. 29-32; and Tangredi, All Possible Wars?: Towards a Consensus View of the Future Security Environment, MoNair Paper 63 (Washington, DC: National Defense University Press, forthcoming), pp. (to be provided).

${ }^{4}$ For the purposes of this argument, the U.S. Air Force is considered a navy that wants to act as an army. The air is a fluid medium of exchange. However, air power theory is primarily focussed on strategic bombing to destroy the enemy's will to fight, or (in the more recent world of smaller-scale contingencies) compel them to desist from completing an undesired activity. The inherent contradiction between medium
} 
challenges some of the current jointness dogma. If, in fact, armies and navies perform completely different functions - territory control and access control--that overlap only on the margins, can there really be a 'joint concept of operations' that equally integrates both? Or is the search for 'absolute' jointness a Congressionally-driven fantasy that simply obscures the dynamically changing balance between territory and access control that the U.S. military had mastered during the Cold War? Others in the past have pointed to cultural differences between soldiers and sailors (and Marines and airmen), as a potential inhibitor of an increasing spirit of joint service. ${ }^{5}$ But perhaps jointness properly has a different form than simply organizational interoperability or unification of command. Under the functional definition - and a broad interpretation of what constitutes naval forces--the traditional delineation between land power and sea power begins to blur. $^{6}$

\section{Why No Other Navies?}

Let's go back to our opening statement that there are no navies, and ask why.

Of course we are defining navies as ocean going fleets capable of sustained outof-area power projection operations. Most nations have given up maintaining fleets capable of sustained out-of-area operations in distant regions. As of the year 2000, all other 'navies' are essentially regional or coastal — the equivalent of the U.S. Coast Guard-

and theory is why strategic bombing fails to achieve successful results, except in certain cases. Of course, it is true that strategic bombing could ultimately achieve its objectives; after everything is bombed to debris and most of the population killed, offending actions generally stop. This could be said to be the theory of nuclear war once embraced with vigor by air power proponents.

5 Of note is RADM J.C. Wylie, USN, "Why a Sailor Thinks Like a Sailor," United States Naval Institute Proceedings 83:8 (August 1957), pp. 811-817, and Carl Builder, The Masks of War (Baltimore: Johns Hopkins University Press, 1989).

${ }^{6}$ This broad definition includes military operations in space and cyberspace, both of which are mediums of communications,transformation and exchange similar to the oceans. Admittedly, the current division of roles and missions of the U.S. Department of Division assigns significant or primary responsibility to joint commands or Services other than the United States Navy. However, that in no way lessens the fact that 
-with the exception of the fleets of the United Kingdom and France, both long-term U.S. allies? And even these two ocean-going navies are shadows of their former selves, capable of extended deployments in relatively small numbers. Several other NATO nations, notably Italy and Spain possess at-sea aviation capabilities. The former Soviet fleet, once sole challenger to American sea power, is a defeated and ruined hulk. Its successor, the Russian Navy, is left with but a handful of seaworthy vessels. Other countries, notably China and India, are building up their naval capabilities, but sustained out-of-area operations are far beyond their reach.

An obvious reason for the demise of navies is economics. Navies require tremendous resources. The main economic inhibitors are the cost of maintaining the logistic capabilities required by an ocean-going fleet, and the cost of the modern naval technology to make such a fleet combat credible in the modem world. Most nations simply cannot or do not want to afford it. But perhaps even more important is the general lack of a naval threat to the security of most nations, and hence the motivation to afford an ocean-going navy. The collapse of the Soviet Union ended the global naval competition that pitted the United States and other NATO navies, along with other allies, against the expanding Soviet Navy. With this Western victory and the fact that the U.S. intended to keep a superpower-sized navy, there seemed little reason for most nations to maintain an ocean-going navy at all.

The result is that the U.S. Navy can be considered a 'globalized' as well as global navy. In essence, it is no longer solely the United States' navy; it has become the world's

operations in those mediums are essentially noval in nature. See discussion in CDR Sam J. Tangredi, USN, “Space is an Ocean,' United States Naval Institute Proceedings 125:I (January 1999), pp. 52-53. 'With 93 cutters (warship equivalents) and 209 aircraft, the United States Coast Guard is itself larger than the naval forces of most nations. 
navy-delivering the security of access function across the entire world system. When Kuwaiti oil tankers required escort to transit the Arabian Gulf in the midst of the IranIraq war, the U.S. Navy was the force of choice. When Asian tiger economies - such as that of Taiwan — are shaken by the bellicose posturing of a neighbor, it is the movement of U.S. naval forces into the region of potential crisis — such as the Taiwan Straits - that provides the prime means of psychological re-stabilization. Recent studies have attempted to quantify this stabilization effect on markets.'

Moreover, with the exception of the "states formerly known as rogues, 9 and the Chinese Communist Party, no one expects much harm from the United States Navy. Japan, which is potentially America's number one economic rival, even allows the U.S. to homeport both a carrier battle group (CVBG) and amphibious ready group (ARG) in its own port cities - and pays for the infrastructure to do so. When building its own ships, Japan routinely licenses technology used by the U.S. Navy. Russia, with a military still vaguely suspicious of the West, has conducted post-Cold War exercises with NATO (and U.S.) naval forces. It would probably conduct more except for the disastrous state of its navy and the desire to hide the real low state of its readiness (made evident in the Kursk rescue attempt). The U.S. Navy is welcomed to ports around the globe, and the forward naval presence of U.S. warships is readily accepted - if not advocated — by most

\footnotetext{
${ }^{8}$ See Ron Brown et al., Forward Engagement Reauirements for U.S. Naval Forces: New Analutical Aporoaches, Report NPS-OR-97-011PR (Monterey, CA: Naval Postgraduate School, 23 July 1997), and the summary of efforts in Sally Newman, "Political and Economic Implications of Global Naval Presence," in Naval Forward Presence: Present Status. Future Prospects (Washington, DC: Center for Strategic \& International Studies, November 1997), pp. 47-59.

${ }^{9}$ The Washington Post reported that on June 19,2000, Secretary of State Madeleine K. Albright announced that the Clinton Administration would no longer use the term 'rogue states,' but that "henceforth nasty, untrustworthy, missile-equipped countries would be known as 'states of concern." This would appear to be a reaction to a recent meeting of the South and North Korean heads of state. See Steven Mufson, “What's In A Name? U.S. Drops Term 'Rogue State,' Washington Post, June 20,2000, p. 16. However, the term 'rogue state' is ubiquitous within the analytical literature.
} 
nations as a sound policy for maintaining regional security. This, again, dissuades most states from making considerable investment in navies."

Of course, this gives the United States certain advantages in the same way that the internationalization of the dollar or the U.S.-led computer industry does in other 'markets.' It allows the United States to set the rules and protocols of yet another slice of the many processes involved in "the expansion of cross-border networks and flows" that is currently being defined a globalization." But this is not an unprecedented state of affairs. The Royal Navy gave the British Empire a similar advantage during long periods of the $18^{*}$ and $19^{\text {th }}$ centuries. What is different is an evolution in naval technology that now allows naval forces to apply power directly to land. Whereas directly influencing events on land formerly required occupation by armies, technology now allows navies to expand the regions to which they control access.

\section{Extending the Effects of Access Control}

Earlier it was argued that navies and armies overlap on the margins. For the U.S. Navy, this 'margin' is growing ever wider as the reach of American naval forces keep extending over land. Moving from the theoretical to the operational, it is apparent that U.S. naval forces are now capable of achieving objectives that previously required the independent introduction of land forces and land-based air forces into theaters of operation. And these naval capabilities are continuing to grow. Sea-based forces, when combined with space-based reconnaissance and information network assets, hold an ever-

\footnotetext{
Curent Secretary of the Navy Richard Danzig discusses this concept of 'dissuasion' in Danzig, The Big Three: Our Greatest Security Risks and How to Address Them (New York, Center for International Political Economy, February 1999).pp. 22-24.
} 
increasing potential to - in the words of former Chief of Naval Operation Admiral Jay Johnston — "influence, directly and decisively, events ashore from the sea — anytime, anywhere."12

The most recent evidence of this growing potential is the use of sea-based cruise missiles to attack and neutralize sites connected with terrorism and with the development of weapons or mass destruction(WMD). The 1998 Tomahawk attack against Bin Laden's terrorist network headquarters in Afghanistan appears the first use of naval power as the sole means of striking targets in a land-locked country. Metaphorically, this represents the projection of power from the margins of the maritime world-described as "rimlands" in earlier geopolitical theory-into the very 'heartland' of global terrorism. 'Heartlands' were previously the exclusive province of armies.

At the same time, the Office of the Secretary of Defense has acknowledged the common-sense approach of focusing the joint quest for theater-wide ballistic missile defenses on upgrades to the already existent AEGIS system. Utilizing the inherent mobility of ships at sea would allow for rapid positioning of robust air and missile defenses within littoral regions under potential threat from "heartland" adversaries.

Over the past years, both experimentation and actual intervention — such as Operation Uphold Democracy in Haiti - have demonstrated the advantages of commanding Joint Task Force operations from command-configured ships at sea. As information, communications technologies and space systems simultaneously advance,

${ }^{11}$ Definition from Ellen L. Frost, "Globalization and Security: An Overview," in Institute for National Strategic Studies, The Global Centurv: Globalization. World Politics and U.S.National Security (Washington, DC: National Defense University Press, forthcoming), p. 2.

${ }^{12}$ Admiral Jay Johnson, USN, “Anytime, Anywhere: A Navy for the 21" Century," U. S. Naval Institute Proceedings 123:11 (November 1997), pp. 48-50. 
the reach of such command platforms - particular under a network centric approach — appears virtually unlimited.

But all these developments represent merely the tip of the iceberg of the everincreasing capacity of forces "from the sea" to direct their effect-producing efforts and energies onto land. They do not yet represent a replacement of an army's capability to occupy territory. However, this extension of access control and denial is made possible by the intertwining of two threads that allow for a landward tilt to naval strategy: an evolution in naval technology that extends the reach of naval forces, and a 'revolution in naval affairs' in which the U.S. Navy become the world's navy.

\section{Evolution and Revolution in Naval Affairs}

Unlike much of the "hype" surrounding the highly touted cyber-based revolution in military affairs (RMA)—a revolution that may have altered the nature of weapons systems, but not yet altered the nature of war itself — the reality of recent naval developments is quietly apparent. They have altered the nature of war on land by providing and increasing the asymmetrical means by which forces of the United States — using the oceans as its operating base-can remain actively engaged in deterring or defeating potential regional crises.

These developments are not based primarily on a single unanticipated technological change, but on continuing evolutions in technologies that combine with an American strategic objective that has remained constant since her founding. This objective - to use our natural position as a maritime power to ensure our defense and prosperity while encouraging peace and democracy worldwide—has previously been a continuing impetus to the development of American sea power. 
Progressive evolutions in naval technologies are increasing the direct effects of sea-based weapons into battles on land. There have been steady improvements in both the range and precision of ordnance and the range and self- sustainability of platforms. Tomahawk land-attack cruise missiles can strike targets at ever increasing distances. Warships - particularly nuclear-powered aircraft carriers — have increased range and weapons payload. Amphibious forces - tied together through the doctrinal framework of Operational Maneuver From the Sea (OMFTS)—can strike from further distances and can sustain a greater variety of operations for a longer period of time. Advances in supporting technologies, such as navigation systems, allow for more precise usage of both advanced and so-called "legacy" weapons systems. Faster speeds in information processing systems provide for multiple sortie rates.

Over the past three years, Vice Admiral Arthur Cebrowski, USN and Art Garska have developed the term "network centric warfare" to describe a methodology for utilizing these ongoing advances in naval and informational technology. ${ }^{13}$ Networkcentric warfare, a term already being adopted by the other Services-most notably the Air Force, is defined as "the strong networking of a well-informed but geographically dispersed force." As the concept of network centric warfare becomes further defined, the expected products of this approach are greater precision in effects and faster speed of response. Again, this represents a continuing evolutionin the use of technologies to enable naval forces to achieve direct influence on events on land.

\footnotetext{
${ }^{13}$ See Vice Admiral Arthur K. Cebrowski, USN and John J. Garstka, "Network-Centric Warfare: Its Origin and Future," U.S.Naval Institute Proceedings 124:1 (January 1998), pp. 28-35, and David S. Alperts, John J. Gartska, and Frederick P. Stein, Network Centric Warfare: Developing and Leveraging Information Superiority, $2^{\text {nd }}$. ed. (Washington, DC: DoD C4ISR Cooperative Research Program, August 1999).
} 
What makes recent developments truly revolutionary is that the influence of sea power on land is no longer indirect, but can now be direct and potentially decisive. The technological evolutionsplus our continuing objective of maximizing our natural access to and from the sea have a synergistic effect. Technology enables the policy objective; the policy objective encourages the technological developments. The one additional element needed to make sea power sharpen its focus beyond the littoral and into the heartland was historical opportunity. And that occurred with the collapse of the Soviet Union and its Navy in 1991.

In effect, the Mahanian concept of decisive engagement was obviated. The 'prerequisite' for access control-command of the seas - was now in the hand of the world's remaining navy. There was no need to conduct war at sea in order to later conduct an access denial war from the sea. ${ }^{14}$

\section{From "...From the Sea" to Beyond the Sea}

The United States Navy did come to recognize this real American "revolution in military affairs" at the end of the Cold War and radically altered its strategic vision In 1992, The Maritime Strategy, with its emphasis on submarine and anti-submarine combat and carrier strikes, was replaced by ...From the Sea, which shifted the naval focus to littoral warfare and direct effects on events ashore. ${ }^{15}$

\footnotetext{
${ }^{14}$ Recent criticisms on the writings of Mahan focus on his supposed fixation on decisive fleet-on-fleet engagements as the means of establishing sea power and dominating the oceans. It seems more likely that his emphasis on decisive engagements was simply a concern as to the prerequisitefor domination in an era in which there were competing navies of comparable strength. Mahan also discussed other means of establishing sea control, but more importantly, he did not foresee the post-Cold War world in which there are effectively no global navies other than that of the United States. In effect, the decisive 'fleet-on-fleet' engagement was the Cold War, which was settled without actual 'blue water' combat.

${ }^{15}$ In 1994, ...From the Sea was augmented by Forward...from the sea, which reemphasized the important role of naval forward presence to deterrence and crisis response. However, ...From the Sea remains the definitive statement of the Navy's current strategic vision.
} 
Analysis of the ...From the Sea vision have appeared elsewhere and will not be repeated here. ${ }^{16}$ But what should be noted is that while the Navy held back from an extensive reexamination of the relationship between sea power and land power-for the reasons of bureaucratic politics--there is a growing body of literature that suggests that if the United States were to seriously implement ajoint ...From the Sea strategy, seapower will become the Zandpower of the twenty-first century. This is based on the convergence of the 'revolution in naval affairs'--which allows the U.S. Navy to look 'beyond the sea'-with three strategic factors unique to the United States: (1) its geographic location and extensive international interests, (2) its natural aversion to military casualties in less-thanvital conflicts, and (3) the effects of globalization that appear to make access more important than territorial control.

For purpose of identification, this growing body of literature could be referred to as the 'Monterey school' since many of the proponents have current or former links with the Naval Postgraduate School. Jan Breemer has identified the revolutionary supplanting of land power by sea power as "the end of naval strategy," implying that maritime operations have become the underlying basis for all joint strategy. ${ }^{17}$ James J. Wirtz has alternatively described this as a "golden age for American naval strategy."18 Threads of this logic can be traced back to such late-Cold War studies as James J. Tritten's

\footnotetext{
${ }^{16}$ See Edward A. Smith, Jr., "What '...From the Sea' Didn't Say,” Naval War College Review 48:1 (Winter 1995), pp. 9-33; Smith, "...From the Sea: The Process of Defining a New Role for Naval Forces in the Post-Cold War World," in Peter Trubowitz, Emily O. Goldman, and Edward Rhodes, ed., The Politics of Strategic Adiustment: Ideas, Institutions. and Interests (New York Columbia University Press, 1998), and "...From the Sea and Back Again: Naval Power in the Second American Century," Naval War College Review 52:2 (Spring 1999), pp. 13-54.

17 Jan $S$. Breemer, "The End of Naval Strategy: Revolutionary Change and the Future of American Naval Power," Strategic Review 22:2 (Spring 1994), pp. 40-53.

${ }^{18}$ James J. Wirtz, "QDR 2001: The Navy and the Revolution in Military Affairs," National Security Studies Ouarterly 5:4 (Autumn 1999), pp.43-60.
} 
examination of whether "naval warfare is unique." 19 Again, the common theme is of a technological/historical change that allows the U.S. Navy to skip the prerequisite of establishing sea power, and go directly to the task of directly effecting events ashore.

Rather than merely replicating their arguments, it is better to enhance their premise by pointing to an additional phenomenon of the changed international system: globalization.

\section{The Influence of Sea Power on Globalization}

The process of globalization has a secret that thus far has been unexamined. In terms of access control or denial, sea power gives a nation-state a great advantage in harnessing the process called globalization.

If, as previously described, globalization is a "process of expansion of crossborder networks and flows," then naval forces, broadly defined, are both the potential protectors and potential inhibitors of such a process of expansion. The traditional language of sea power--with its concern for the 'sealines of communications' (SLOCs), blockades, fleet-in-being, and naval presence--may seem like a quaint 'legacy' dialog to those schooled in information technology and e-commerce. But though it may not use the same grammar, it uses the same logic.

The traditional goal of sea power is unfettered access to the world's common transportationroute for raw materials and manufactured products, as well as access to the actual markets and sources of materials themselves. The emerging concept of the "new economy' revolves around access to the world's common electronic information routes-

"James J. Tritten, "Is Naval Warfare Unique?" Journal of Strategic Studies 12:4 (December 1989), pp. 494-507. 
such as the internet — and the sources of information, as well as the potential markets for value added to the information. Like every other such shaping process, globalization, at its very heart, involves a struggle for economic and political power - a struggle for access to the fruits of the process.

This 'struggle' includes access to the infosphere, access to financial markets, access to raw materials (of which information is one), access to the means of production, and access to the market population. And just as a 'hacker' can use 'information warfare' to delay, disrupt, distort or deny access to the infosphere, more traditional military forces - and primarily those forces that operate from with the mediums of interaction-can deny access to the sources of the production of wealth. The maintenance of a force that can operate from within the mediums--i.e., a navy--is a form of insurance that such physical access could not be cut by other military force - at least not without a war. And as previously pointed out, navies are the means of access denial to opponents or rivals. While operating with the 'global commons' of the sea, their movement is protected and sanctioned in peacetime by international law.

As stated, armies are designed to control territory; navies are designed to control uccess. If globalization is really breaking down the territorial barriers of our world — which is what most of 'proponents' of globalization suggest — then access to information, markets or resources is becoming even more important to the world's political economy than control of territory, no matter how fertile or resource-filled, or populations, no matter how productive. This would suggest that navies are becoming more important as well. But, as we stated in the beginning, there is only one navy. 
As the sole global navy, the U.S. Navy can —within polite limits in times of peace-determine the when, where, and how of the world maritime exchange. This represents the direct influence of (United States) sea power on the overall globalization process. Because of the United States commitment to global trade and access (at least on a theoretically even basis), what is good for the United States is generally good for all other trading states, and the day-to-day impact of sea power on the globalization phenomenon appears transparent. But, if 'push came to shove,' there is no alternative maritime security 'service.' This ensures that U.S. influence can never be quite 'outvoted.' Like the U.S. dollar in international commerce, and the use of English language in the development of information technology, the U.S. Navy provides a dominant standard that ensures American predominance. Rome or Britain in former days asked for just such an advantage from their navies.

By protecting the access to this open market to all those who accept international law, the U.S. Navy provides a common security function on a global basis. In reality, it provides the 'protocols' and security structure of the maritime 'internet;' which, in terms of international trade in goods, remains the ultimate 'internetted' exchange. Naval strategy in the contemporary world is all about controlling such access. The effects of this access goes far beyond the sea.

\section{Force Structure for the World's Navy}

For readers who still find the opening sentences of this chapter too dramatic, consider the enormous disparity between the sole global navy and the other fleets that some might still refer to as navies. 
The U.S. Navy simultaneously operates major fleets in the Mediterranean, Arabian Sea, western Pacific, eastern Pacific and Atlantic, as well as well as individual ships and squadrons in almost every other clime or locale. In terms of mission capabilities, the U.S. Navy is capable of carrying out the entire spectrum of imaginable naval missions, from support to civil authorities - which is the euphemism for counterdrug trafficking patrols and domestic disaster relief assistance - to thermonuclear war. In its mission of forward presence, the U.S. Navy conducts the routine and near-continuous deployment of combat capable naval forces to the crisis regions of the world. Organizationally, the Navy possesses an air arm comparable to the entire air forces of most nations, as well as surface and undersea vessels and -as part of the overall Department of the Navy -its own amphibious-capableland army of almost 200,000 elite troops. Its reach extends from the very depths, or at least as deep as its deep submergence vehicles can reach, into space with specialized satellites in earth orbit. U.S. naval officers have walked on the moon.

With the exception of Russia, China, and the 'states formerly referred to as rogues,' almost all national navies utilize concepts and procedures derived from or similar to those of the U.S. Navy. This ensures a certain degree of interoperability; even those navies that can not establish an electronic link with U.S. tactical information networks are generally well versed with Allied Tactical Publication 1, the NATO signal book for naval operations.

The U.S. Navy routinely conducts combined exercises and operations, and policy discussions with almost every other fleet. Operations range from NATO's highly integrated Standing Naval Forces Atlantic (STANAVFORLANT) and Standing Naval 
Forces Mediterranean (STANAVFORMED); to frequent exercises with Latin American and Asian navies, and Australia; to passing exercises with friendly coastal navies, such as Oman; to even occasional exercises with Black Sea navies, including Russia. A biannual seminar, known as the International Seapower Symposium, brings high level representatives from almost every naval staff —including Russia and China - to the Naval War College in Newport for discussions of naval policies. The backdrop is familiar to them; many of the world's senior naval officers are graduates of the U.S. Naval War College. Bilateral talks between the Chief of Naval Operations' staff and its foreign counterparts occur almost every week.

Forward presence - the continual deployment of naval forces to potential regions of crisis - places the Navy in the forefront of the proverbial 'global security market.' Like the best of global corporations, the U.S. Navy maintains 'representatives' in the immediate vicinity of its significant 'customers.' Not a day goes by in which U.S. Naval forces can not strike in some fashion at the forces of Saddam Hussein, Slobodan Milosevic, international terrorists, or maritime drug traffickers, to name but a few potential threats to international security.

But will the U.S. Navy's force structure ensure such dominance in the future? Are the Navy's future programs designed to deal with future globalization effects? Are other platforms, platform mixes, operational concepts needed? It is one thing to talk of theories of sea power, but implementing any naval strategy requires forces and resources. The prudent defense planner will inevitably focus on a simple request: show me the money. 
Well, there are some issues that may cloud this image of a 'golden age.' One of the public concerns expressed by both Congress and the Navy leadership is the overall size of the Navy and the number of ships in the fleet. With the end of the Cold War, the Navy, along with her sister Services faced substantial reductions. Overall U.S. defense spend was reduced by over one-third. Depending how one calculates fleet size, the U.S. Navy was reduced by almost one-half. During the 1980 s, the Reagan administration pushed towards a 600 ship Navy, although that actual number was programmed, but not reached. The latest defense structure review, the Quadrennial Defense Review of 1997 called for a fleet size of slightly above 300 ships (current size is 316 ), which was deemed sufficient until 2015.

However, the significant number of SSCs in which the Clinton administration has chosen to become involved has increased the operational tempo of the Services severely enough to cause great strains in the force. A fleet of 316 ships does not have a large enough rotation base to provide a carrier battle group (CVBG) and an amphibious ready group (ARG) for all three of the critical theaters of interest (Mediterranean, Arabian Gulf, Western Pacific) simultaneously, as requested by the Commanders-in-Chiefs(CINCs) of the Unified Commands. While almost one-third of the Navy is forward deployed for a period of six months, the rest of the fleet is in overhaul or training for deployment. Instead of being able to provide this “ 3.0 presence," naval deployment presence (1 CVBG and $1 \mathrm{ARG}$ per theater), worldwide presence varies between 2.5 to 2.7. To maintain 3.0 presence would require a fleet of approximately 360 ships. $^{20}$

\footnotetext{
${ }^{20}$ Department of Defense, Report to Congress on Naval Vessel Force Structure Requirements, 26 June 2000, p. 4.
} 
The fleet reduction was achieved by decommissioning ships earlier in their lifespan and reducing the ship construction budget. However, the current ship construction level can no longer replace ships that are reaching their normal decommissioning age. If ship construction is not increased, the Navy will inevitably fall below 300 ships by $2010^{21}$

This shortage can become particularly acute if globalization trends increase the requirements for naval presence, engagement and contingency operations. ${ }^{22}$ Although it may be possible to increase the length of ship deployments and reduce their maintenance times, this has a deleterious effect on both equipment readiness levels and personnel retention. Secretary of Defense William Cohen has recent endorsed the Navy's proposal for the 360-ship fleet. ${ }^{23}$ However, currently there is no strong Congressional support for the budget increase required and such an increase is doubtful.

But perhaps fleet size is ultimately less critical than its actual composition. A large fleet of smaller, less capable ships is not necessarily as effective as a smaller fleet of more powerful ships. Additionally, individual ship characteristics need to include increased levels of protection against WMD (primarily chemical and biological weapons) as these weapons proliferate. The current configuration of the Navy seeks to balance combat firepower With multi-mission capability and the requirements for naval forward presence. However, the 'rightsizing' (downsizing) of the 1990s has resulted in the divestiture of naval capabilities on the 'low end' of the balance. The search for a capabilities-sizebalance in a globalized world would require an assessment of desired

${ }^{21}$ Chuck McCutcheon, “The Navy Pushes for More," Air Force Magazine 83:7 (July 2000), p. 57.

${ }^{22}$ It should be acknowledged that the total Navy is composed of units other than ships and aircraft squadrons, such as Naval Construction Battalions (Seabees), Explosive Ordnance Disposal (EOD) Units, Sea-Air-Land (SEAL) commando teams, and others. They will not be addressed in this chapter. 
ship characteristics, and might indicate the value of new ship concepts. The following short survey barely scratches the surface of issues requiring considerable detailed analysis.

Aircraft Carriers. The large through-deck carrier capable of operating 'conventional take off and landing' aircraft is a virtual U.S. monopoly in capability. No other nation operates such ships, although all other potential 'blue water' navies formerly aspired to do so. ${ }^{24}$ However, critics - focussed on the enormous cost of building and operating such floating airfields—question their survivability in an anti-access environment.

While the expense of carrier construction is undeniable, their survivability in an anti-access environment would seem much greater than overseas land bases (assuming prudent employment), and their capability to remain on station is obviously much greater than long-range aircraft. If direct engagement and presence is required in a 'not-yet-hotwar' environment, they are unparalleled assets. The key advantage is great flexibility — an airfield that can move at relatively high speeds and defend itself by maneuver as well as strike. An aircraft carrier is re-locatable American temtory which is readily used in demonstrating American interest and resolve. Its disadvantage is the vulnerability to submarines — a problem that has existed under previous conditions and can only be mitigated through the combined-arms operations that has been the existing

23 “Cohen Admits Navy's Force Size Is Stressing Sailors and Marines,” Inside the Pentagon, June 29,2000, p. 1 .

${ }^{24}$ The Soviet Navy built smaller carriers and eventually constructed several large carrier hulls, but were unable to perfect comparable carrier operations. The French Navy has recently constructed a large nuclearpowered aircraft carrier, the RFS Charles De Gaulle. However, she has had numerous design and construction problems, and sea trials indicate she is not yet operational. 
fleet concept. ${ }^{25}$ The type of aircraft that can be operated and the sortie rate are less than that of overseas land bases, but a combination of carrier operations and long-range aircraft (Air Force bombers) would seem to have the greatest capacity for probing and breaking through anti-access defenses.

The Navy's recent report to Congress calls for a force of 15 carriers to provide $\mathbf{3 . 0}$ worldwide peacetime presence. Such a force could not be built or maintained without a substantial increase in the Navy's budget. The bottom line appears that evolutionary improvements in carrier design make such a platform desirable in a globalized future, but cost reduction--for what is in effect a self-sustaining overseas air base--is problematic. Perhaps the most substantial increase in efficiency could come about by their use as a joint command and control center for overseas land operations.

Aviation Squadrons. The overall U.S. Navy aviation program has focussed on improving relatively short-range strike aircraft, such as the F/A-18. A globalized antiaccess environment would appear to call for longer range and greater relative stealth in such aircraft. Additionally, internetted defenses would seem a prime target for electronic warfare aircraft, an expertise that appears primarily resident in the Navy and Marine Corps EA-6B Prowler squadrons.

Recent regional interventions have made the shortage in existing EA-6Bs very evident, and it is surprising that the Navy has not pursued an increase/enhancement of electronic warfare aviation systems with greater alacrity or apparent interest. To be

\footnotetext{
${ }^{25}$ Critics maintain that carriers are vulnerable to ballistic and air or ground-launched cruise missiles, but these are easier to defend against by combined arms fleet operations than submarines. Largely this is due to the physical properties of the operating mediums. Unless ballistic missile warheads were enhanced with terminal homing —a major technological advance, or massive saturation attacks were directed against individual ships - a costly and inefficient strategy, conventionally-armedballistic missiles would not be serious threats against maneuvering warships. Obviously, nuclear weapons are a greater magnitude of
} 
effective in regional conflict in a globalized world, electronic/cyber warfare can not be confined only to space or ground assets —at least not without giving up a certain degree of precision and local effectiveness.

Attack Submarines. ${ }^{26}$ With the end of the Cold War, the U.S. nuclear attack submarine (SSN) inventory was cut dramatically from a force of about 100 to a planned force slightly above 50 . This represented the perception that the former-Soviet submarine force - much of which is no longer operational — representeda much reduced threat.

Recently, however, the Navy has argued that the planned submarine force will not be large enough to carry out all the engagement and intelligence operations required by the CINCs, along with providing two submarines as part of every deploying carrier battle group. The latter is organizational choice by the U.S. Navy, rather than a joint requirement. But, in any event, studies of joint requirements have specified the number of 68 SSNs as the desired force level. ${ }^{27}$

Due to their stealth and flexibility, submarines would appear to be a priority asset for a globalized world, particularly in the intelligence, surveillance, and reconnaissance (ISR) role as well as 'blue water' sea control.

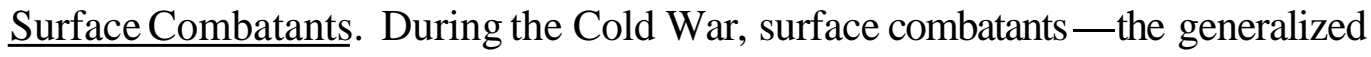
term for cruisers, destroyers and frigates — were deliberately multi-purpose designs optimized for war at sea, as opposed to land attack or strikes against land targets--which could be considered war from the sea. But with the absence of a global naval threat,

threat - as they would be against any target. Cruise missile attacks at sea require real-time targeting data or proximity, both of which are difficult to obtain against an alerted fleet.

${ }^{26}$ Nuclear ballistic missile submarines (SSBNs), which are national deterrence assets subject to arms control limitations are not addressed in this chapter. 
surface combatants are currently prized for their current capability to launch the nearlyubiquitous Tomahawk land attack cruise missile (TLAM), and their developing capability of Theater Ballistic Missile Defense (TBMD).

Both missions would appear to retain their relevance in a highly globalized world. In fact, theater ballistic missile defense could be the greatest asset in demand during future periods of potential crises. The advantage of naval TBMD is the fact that it is rapidly and highly mobile, but with near indefinite on-station time, and that it uses an already existing air defense combat system that might be capable of future upgrades for cruise missile defense.

The current Navy program includes the development of DD21, a destroyer-sized platform designed specifically for land attack. As conceived, DD21 would require a drastically reduced crew size than the current DDG-51 class, possess but a modest selfdefense capability, and take much of its targeting data from off-ship sensors. However, with of its relatively large size, it would appear to be giving up survivability without a significant improvement in strike capability over existing assets. An alternative in a dense anti-access environment might be a significantly smaller vessel with similar characteristics, such as the 'streetfighter' proposal described below.

Amphibious Warships. When the Navy shifted from its Cold War "Maritime Strategy," to the littoral focus "From the Sea..." strategy, greater emphasis was placed on modernization and new concepts of operation for the amphibious fleet. This, in turn, seemed to herald an ever-increasing integration between the Navy and Marine Corps. But these developments have cooled recently, reflecting a return to the Navy's traditional reluctance to prioritize assets for a 'Marine' fleet. Modem assets, such as the LPD-17

27 “Cohen Admits..."," p. 1 
class are being developed to replace older, more specialized amphibious ships (most of which are already decommissioned) and achieve the 2.5 Marine Expeditionary Brigade (MEB) lift requirement mandated by Congress. However, certain previous-held capabilities, such as the ability to pump fuel directly to forces operating ashore, are being quietly discarded. If a globalized world require a greater number of interventions in the littoral regions — where most of the world's cities are located - it would seem prudent to increase rather than decrease such combat-capable maritime support for land operations.

Patrol Combatants. Since they are not independent, sea going vessels and possess very light armament, it is very difficult to deploy the current small class of patrol combatants to theaters of crisis in a timely fashion. Used almost exclusively as Special Operations Force (SOF) assets, the Patrol Combatants are not integrated into fleet littoral ops. But if a globalized world requires greater near-shore engagement, such vessels would seem to have a significantrole. Two possible solutions for increasing this capability would be: (1) constructing patrol combatants to be able to fit in the well decks of the current and future amphibious fleet, or (2) develop a more lethal, more survivable combatant with greater sea-keeping capabilities — similar in concept to the 'streetfighter' described below.

There are a number of concepts recently proposed that may prove to be useful adjustments to fleet structure under the requirements of the future. With the exception of network-centric warfare, which has been frequently discussed but is still in the conceptual stages, these proposals have not been adopted in future Navy programs.

Arsenal Ship/Arsenal Sub. An 'arsenal ship' consisting primarily of a large number of vertical launch tubes and a small crew, requiring targeting data and protection 
from other naval platforms was a proposal particularly intriguing to the late-Admiral Jeremy M. Boorda, formerly Chief of Naval Operations. Although official scrutiny of the proposal did not long survive Admiral Boorda's demise, a variant that has gained increasing popularity among defense analysts and Congress is the 'arsenal sub.' The prototypical variant is a converted Trident SSBN that replaces the ballistic missile tubes with multiple cruise missile tubes capable of firing TLAMs. Although arms control limits creates some complications, the use of an existing submarine hull could provide such an 'SSGN' at a much lower cost than new construction. The advantage of an SSGN over a surface arsenal ship is its obvious stealth characteristics, which would seem particularly valuable in a globalized world/anti-access environment. The Navy's recent Reuort to Congress on Naval Vessel Force Structure Requirements identifies the SSGN proposal as being "under consideration."

Network Centric Warfare. As previously discussed, the concept of network centric warfare (NCW) could be described as a shift in focus away from 'platforms' to 'network.' Network-centric operations promises to increase the value of individual units by providing a more effective informational linkages and a common operational picture, that, in tum, allow for the optimization of weapons and effects. Conceptually developed by Vice Admiral Arthur K. Cebrowski, current President of the Naval College, $\mathrm{NCW}$ is clearly in sync with globalization trends concerning information. One area of concern is the increased vulnerability that a tight tactical internet could have if any of the access nodes were penetrated by an enemy. 
Littoral Supremacy Ship. Suggested in the writings of retired Admiral Bill Owens $^{28}$ and elaborated upon by others, ${ }^{29}$ the littoral supremacy ship is a proposed combination between surface combatant and amphibious warship that is optimized for land attack. Vertical launch tubes installed in an amphibious-type hull (with well deck and flight deck) could be stocked with TLAM missiles, substantially increasing the number of Tomahawk shooters in the fleet. The tubes could also be used for enhanced air defense weapons, or shorter-range fire support missiles to provide fires for troops engaged in combat ashore. ${ }^{30}$ The advantage of the proposal is the potential for a reduction in different ship types assigned to the fleet, thereby achieving economies of scale in construction, maintenance, and training. Although still a vessel of considerable size, capable of operating 'vertical or short take-off and landing' (VSTOL) aircraft, the littoral supremacy ship would sacrifice 'blue water' warfighting capability for land attack and self-defense weaponry. Ultimately, it is postulated on the belief that the U.S. Navy will remain unchallenged in the oceans. The littoral supremacy ship concept has not yet been seriously examined by the U.S. Navy.

Mobile Offshore Base (MOB). First proposed in the late 1960s, the concept of a Mobile Offshore Base consisting of a series of connected offshore oil platform-like structureshas been periodically reexamined. It recently attracted renewed interest through Admiral Owens and several studies and proposals developed by potential MOB

\footnotetext{
${ }^{28}$ VADM William A. Owens, High Seas: The Naval Passage to an Uncharted World (Annapolis, MD: Naval Institute Press, 1995), pp. 166-169.

${ }^{29}$ See discussion in CDR Sam J. Tangredi, USN, "A Ship for All Reasons," U. S. Naval Institute Proceedings 125/9 (September 1999), pp. 92-95.

${ }^{30}$ The LPD-17 ship class currently under construction was originally designed to have such vertical launch tubes. Ostensibly a cost reduction decision, the elimination of vertical launch capabilities in the amphibious fleet was probably prompted by potential funding threats to $D D \cdot 21$, the future land attack destroyer. But it was a missed opportunity for enhancing fleet striking power at a very modest overall cost. The littoral supremacy ship is the potential alternative to a strictly specialized surface fleet.
} 
builders. ${ }^{31}$ The technological difficulties in linking oil platform structures in a relatively moderate sea-state are challenging, but not insurmountable. The goal would be a composite platform capable of being used as an air base capable of operations by almost all aircraft in the U.S. Air Force inventory. In contrast to the 80-100 marinized aircraft that can be operated off today's largest aircraft carriers, the proposed MOB might be capable of operating over 300 aircraft, including large transports requiring a long runway. MOBs would be constructed at sea in the major deployment hubs, or off areas of long term crisis. In effect, they would provide the same capacity as an overseas air base ashore without the force protection requirement (such as anti-terrorism defenses) or vulnerability of a fixed land target. Unlike an aircraft carrier, the MOB could move only at very slow speeds (less than 5 knots), and would probably require disassembly to make a major relocation.

The advantage of the MOB proposal is the vast size and aircraft sortie rate generation it could bring to areas of long-term American commitment. It would be an asset that satisfied numerous joint service requirements. However, it would probably still require naval battle group assets for its defense, and obviously lacks the flexibility and survivability characteristics of an actual carrier.

If a globalized world required a continuing American presence in an area where land bases were not readily available or subject to an anti-access threat, the MOB could prove a viable alternative to land basing. However, because its funding is seen as a competitor for the future resources of the aircraft carrier fleet, MOB development is currently opposed by the Navy's leadership. Although a 'joint asset,' no other Service has indicated serious support for the concept.

${ }^{31}$ Owens, pp. 162-166. 
Streetfighter. ${ }^{32}$ A recent conception also championed by Admiral Cebrowski, 'streetfighter' would be a small surface combatant optimized for near-shore land attack. ${ }^{33}$ Under the proposal, 'streetfighter' would be an offensive platform with a small crew, relying on speed, stealth, and point-defense weaponry for self protection. Such a ship could be purchased in large numbers, thereby allowing it to be 'more expendable' than larger, 'capital' ships. The historical analogy is the World War Two Patrol Torpedo (PT) boats that operated in the Pacific island archipelagoes. Much more technologically sophisticated that their predecessors, 'streetfighters' would be armed with land attack missiles (and possibly long-range guns), rely on remote targeting data for its strikes and be supported for logistics and repair by a sea-going mother-ship (possibly similar to the littoral supremacy ship). Thus far, 'streetfighter' has received a lukewarm reception by the majority of naval leaders.

Counter-Mine Warfare. Beyond any doubt, counter-minewarfare is currently the weakest capability in the U.S. fleet inventory. The historical reason is that in the Cold War the mission was relegated to Allied navies (particularly NATO allies) that could not afford to construct large ocean-going ships, but could best spend their resources by specializing in a specific function. But with the Cold War over, this 'specialization agreement' is in doubt. And the U.S. Navy operates in regions in which NATO allies may not venture.

\footnotetext{
${ }^{32}$ Recently the term "Corsair" has been used in place of "Streetfighter" in Naval War College briefings on this concept.

${ }^{33}$ See public discussion in VADM A.K. Cebrowski, USN and CAPT Wayne B. Hughes, USN (Ret.), "Rebalancing the Fleet," U. S. Naval Institute Proceedings 125/11 (November 1999), pp. 31-34;LCDR Dave Weeks, USNR, "A Combatant for the Littorals," U. S. Naval Institute Proceedings 125/11 (November 1999), pp. 26-30; and CAPT Wayne B. Hughes, USN (Ret.), "22 Questions for Streetfighter," U. S. Naval Institute Proceedings 126/2 (February 2000), pp. 46-49.
} 
Since sea mines are one of the cheapest anti-access weapons readily available on the open market, recent trends would require the U.S. Navy to formalize the counter-mine 'specializationagreement' or increase its capability at mine hunting and clearing, a capability that was sorely taxed in the Gulf War. This issue is not a pressing one for a navy that operates in the deep 'blue water' of the oceans, where mines can not normally be placed. But it becomes critical as a prerequisite for littoral operations. This capability has not increased at the same rate as the U.S. Navy's interest in and commitment to littoral warfare.

Future naval programs are focussed on developing "organic" mine-hunting capabilities that could be added to multipurpose surface combatants and submarines. But this simply adds yet another mission to ships that are already tasked with strike, theater ballistic missile defense, anti-submarine warfare, and fleet air defense. Unless a significant increase in surface combatants and submarines is programmed, it would seem prudent to make what is a comparative modest investment in additional specialized surface and air mine-hunting/mine-clearing platforms. In order to develop a long-term advocate for this critical mission, it may be appropriate to assign it to another community than surface or submarine warfare, such as to Explosive Ordnance Disposal (EOD).

Combat Logistics Ships. As part of its 'rightsizing'/downsizing, the Navy elected to convert most of its logistics assets into civilian-manned ships operated by the Maritime Sealift Command (MSC). Although the long-term cost reductions may be modest, in the near term this reduces direct costs to the Navy budget, particularly military manpower costs. 
But the logistic fleet is mainstay of all global capabilities. One area of significant reduction that might prove a problem for land attack operations was the complete elimination of destroyer tenders and repair ships, as well as most submarine tenders. The logic of this move was that repair of forward-deployed ships could be performed in overseas ports using foreign assets. But the availability of such foreign assets during wartime is uncertain, and much of the specialized repair needs of U.S. warships can only be obtained at relatively high cost. But more importantly,the decommissioned tenders were the only potential means of reloading vertical launch tubes in the deployed theaters. As of today, expended magazines require surface combatants to steam back to the United States for reload. This may be a considerable bottleneck to long-range land attack missions in an extended conflict.

Evaluating the above alternative force structure concepts in detail would be a most complex, but worthy challenge.

\section{Conclusions: The Ultimate 'Jointness'}

Here's where we tie the above discussions together. Since naval forces are conceptually structured to ensure or deny global access and interactions, they would appear to be of increasing importance in the contemporary, apparently 'globalizing' world. Benefiting from continuing evolutions in naval technology, the United States Navy—as the dominant 'world's navy--has shifted its strategic vision towards using its control over access to directly effect events on land. Such a shift is made possible by the elimination of any serious challenge to American sea control, which represents a true 'revolutionin naval affairs.' This allows the USN to focus 'beyond the sea,' which is a logical development because the functional definition of naval power is to be the military 
instrument within the fluid mediums of interaction, communications and exchange. As these fluid mediums expand to include space and cyberspace, it is natural to utilize naval forces (no matter what uniform they wear) to control access.

The focus 'beyond the sea' represents a shrinking of the 'margin' between armies and navies and the potential subsuming of land power into sea power. This trend wave has been broached by the writings of the 'Monterey' school.

Such a blend would have undeniable effects on the way that future naval strategy is perceived. It could as likely lead to an end to 'joint strategy,' as it is currently practiced, as to an 'end' of naval strategy. In fact, these effects could be conceived as leading to 'ultimate jointness,' as the United States adapts its military to best utilize its unique naval advantages in a globalizing world.

Within the Navy, these developments should prompt a renewed examination of a myriad of alternative force structure concepts. This chapter has barely scratched the surface of the potential alternatives. Seriously examining an alternative concept does not necessarily lead to adopting significant changes. However, adaptation to a changing international security environment can not come about without it. A 'let a thousand flowers bloom' approach might best be inspired by recognizing a 'deconstructionist', functional approach, rather than the organization definition as to what is a navy.

In the contemporary world there are no navies. But that does not mean that there might be not be a re-creation of navies in the future. There may even be some return to naval strategy as it is traditionally conceived: strategy for military forces fighting $\boldsymbol{a t}$ sea. But in being forced to develop a naval strategy for an era without navies, the U.S. Navy is 
now poised to take naval warfare beyond the constraints of 'time and tide' and apply the advantages of sea power not merely from the sea, but truly beyond the sea. 
Air Power: Theory and Practice

Timothy Garden

Chapter Summary

This chapter traces the $d$ velopment of air power thinking from the earliest days of flight to modern times. It argues that the prophets of air power were often flawed in their predictions. Air power technology developed rapidly and in unpredictable directions. Army and Navy leaders saw the new air systems as little more than extensions of their surface capabilities, and therefore lacked the imagination to develop new methods of fighting. Experience in war forced some military commanders to realise that control of the air was necessary for victory. Strategic bombing was central to the thinking of professional airmen, but was unable to offer certain victory until the development of atomic weapons. Eventually, missiles became more useful as nuclear delivery systems than manned aircraft. At the end of the 20th Century, air power underwent a radical reappraisal after its successful application in a number of limited war campaigns. Precision air delivered weaponry offered politicians an easier option for prosecuting wars.

\section{Introduction}

The history of warfare has been a progressive search for technological advantage. Weapons have been progressively developed for ever greater range. Both on land and at sea, the advantage has gone to the side who could see furthest, and then bring firepower to bear on the adversary. Armies would seek high ground; navies would post lookouts at the top of their ships' masts. Guns were given greater and greater range. The advent of flying machines changed the nature of warfare for all time. In a period of less than a century, military use of the air has moved from tethered balloons to cruise missiles using satellitebased navigation systems. The third dimension of warfare has encompassed space itself. The novelty of the technology has given many problems for those who attempted to develop air power thinking . Often they predicted capabilities which were then beyond the science of the day. Centuries of 
maritime and land fighting experience held back the development of a new three-dimensional doctrine. The first advocates of the use of air power had to fight difficult institutional battles to gain sufficient resources.

In the early days, aircraft, both heavier and lighter than air, were seen as no more than giving extra tactical height to the military commander for his surface battle. Yet the ability to threaten deep behind the frontline was rapidly realised, and governments feared that they would be unable to defend their cities against bombs dropped from aircraft or airships. Limited experience of such attacks in World War One was extrapolated by theorists to claim that the bomber was the war winning capability of the future. In the event, defensive measures, lack of bombing accuracy and civilian resilience meant that World War Two had to be fought by a more traditional and prolonged all arms campaign. It was not until the last days of that war in 1945 that the use of an atomic bomb changed the calculus of warfare. From the nuclear devastation of Hiroshima onwards, it became possible to guarantee the total destruction of cities from the air.

The period from the end of World War Two until 1989was dominated by the potential for a nuclear war between the Soviet Union and the United States. Each, with its allies, fielded increasing numbers of atomic weapons that in the early days would be delivered by aircraft. In later years, missiles became the preferred delivery system. This period of Cold War was prevented from becoming a hot fighting war by the absolute assurance that nuclear weapons delivered from above would leave no winner. Air power played the key role in making war between major powers unwinnable.

Since the end of the Cold War, nuclear weapons have been less prominent in strategic thinking. Smaller more traditional wars have become the focus of international interest. The United Nations has from time to time been moved to right international wrongs such as the invasion of Kuwait by Iraq in 1990. A new approach to warfare has been developed through these experiences in the last decade of the 20th Century. Air power has become much more precise in its application using conventional weaponry. This has allowed powers to exert force without risking either large casualties to their own forces or to noncombatants in the target zone. Air power has become the weapon of first choice: 
to be used ahead of, and perhaps instead of, surface forces. After a century, the world is looking at the use of military force in a new way through the capabilities of air systems.

\section{$\{\{$ BOX 1KEY CONCEPTS $\}\}$}

\section{A New Military Capability}

First uses of air power

Man has dreamt of flying like the birds for all of history. Yet, it was not until 1783 that the Montgolfier brothers in France first overcame gravity in their hot air balloon. By 1794, at the Battle of Fleurus, the French Generals were able to direct the operation from their aerial headquarters. Tethered balloons were developed over the next hundred years to provide useful artillery spotting lookouts. The major limitation of such balloons was their lack of directional control. They had either to be captive with a tethering line, or allowed to drift with the wind. The first dirigible airship was flown by Henri Giffard in France in 1852. Airships continued to be developed for both civil and military use as the internal combustion engine gave a more effective power source. In Germany, Count von Zeppelin made great advances, which were to provide his country with a significant military airship capability. Nevertheless, airships were to remain slow moving and vulnerable as they had to displace large volumes of air to provide the lift for their engines and payload. Speed would require the development of heavier than air flying machines.

\section{$\{\{$ Table1 Air Power Milestones $\}\}$}

Controlled powered heavier-than-air flight was realised at Kitty Hawk, North Carolina on 17December 1903by the Wright Brothers. Military interest was variable, but enthusiasts ensured that airplane technological development was rapid. Louis Bleriot flew across the English Channel in 1909 showing that England was no longer safe as an island nation. In 1911, a Curtiss biplane was successfully launched from and landed back on a warship. That year was to see the first use of air power in war. Italy was at war with Libya, and began using 
aircraft and airships for aerial reconnaissance. By the following year, hand held bombs were being dropped on desert troops below.

\section{Air Power in World War One}

The French followed these trends closely and took the lead in developing air commands. At the outbreak of World War One they had some 138 military aircraft, and had also been building them for Russia. Germany had concentrated its early development work on airships for military use, but it too was building heavier-than-air machines, and had 232 by 1914 . The United States showed remarkably little interest in military aviation developments, which was why the Wright brothers spent their time selling their machines in Europe. The British reorganised their air capabilities into an army specialist force, the Royal Flying Corps, and subsequently added the Royal Navy Air Service in early 1914. In July 1914, shortly after war was declared, the 37 airplanes of the Royal Flying Corps flew across the Channel to France. The primary role of these aircraft was reconnaissance, and they rapidly proved their worth to the land commanders. In the first big battle of the war at Mons, General Sir John French reported that the Royal Flying Corps had provided crucial information on enemy movements. It was however for artillery spotting that the new air capabilities were most used in the early days of the war.

Inevitably, when German aircraft found themselves near French or British aircraft, small arms fire was exchanged. This led to each side developing armaments for their aircraft. From 1915 onwards, the use of forward facing machine guns, which fired through propeller blades, allowed fighter tactics to be developed. Tactical formations of aircraft had their genesis in cavalry manoeuvres, and air to air combat became an activity in its own right. The importance of attempting to control the airspace above them was becoming obvious to commanders, and they needed to give higher priority to this task if they were not to be vulnerable to enemy air reconnaissance and artillery spotting. In many ways, the development of air power progressed ever more rapidly in the maritime environment. Reconnaissance developed into antisubmarine warfare. Air defence fighters were needed to protect cargo ships 
from attack. The British Navy developed its own bomber force to destroy the Zeppelin threat by bombing their bases in Germany.

Although of relatively limited military effectiveness, the most significant air power development of the war was to be that of strategic bombing. Targets were both military and civilian, and the greatest shock was to Britain, which, as an island nation, had long felt secure from enemy attack. As a consequence, the Zeppelin and Gotha raids on London had a disproportionate effect on future air power thinking. Some 9000 bombs were dropped by German airships and aircraft on Britain during the whole of the war, killing some 1413people and wounding a further 3408 . The British public clamour was for air defence at home and retaliatory strikes on Germany.

Air Forces need a separate organisation

The development of air power during World War One was extraordinarily rapid, but was not particularly well thought through. Army and Navy commanders had no experience of what the new technology could offer. It was also expensive in terms of cost of equipment and also in its need for trained manpower. Arguments over funding priorities further hampered developments. This was unacceptable to the British Government, who felt uniquely threatened by this novel military capability. These organisational problems led to the establishment of the first separate military arm for air power, the Royal Air Force, in Britain in 1918. Winston Churchill, who was the politician in charge of the Royal Navy, was quick to understand the importance of an independent system for managing air assets. He pushed forward the establishment of a new Air Ministry to manage all aircraft equipment procurement.

In World War One, air power was used in virtually all of its modem military roles, which were to be greatly developed subsequently. There was no time for theorists to discuss optimum strategies for incorporating this new capability into traditional warfighting doctrines. The airmen of the time had a high casualty rate, which meant there were few available to fight the institutional 
battles. By the end of the war, of the 175,000 military aircraft built by France, Germany and Britain, some 116,250 had been destroyed.

Between the Wars

Air Power Prophets in the Wilderness

With the end of the Great War, there was little general interest in learning the air power lessons of the conflict. The expectation that this had been a war to end war meant that military spending was rapidly scaled down everywhere. In Britain, there was debate as to whether the new Royal Air Force was necessary in peacetime. Certainly, there was little sympathy for spending money on this expensive part of the military establishment. The RAF was reduced within 6 months of the Armistice from 188 operational squadrons to just 23, of which fewer than half could be deployed. Hugh Trenchard, who had served with the Royal Flying Corps, and had risen to be Chief of the Air Staff of the new RAF, became the custodian of British air power thinking throughout the 1920's.He was a strong believer in offensive air power,' and of the importance of the bomber in any future wars. However, in the absence of any planning for major wars, he was better able to promote the RAF in the role of imperial policing. Britain had a large empire to control, but was short of money to fund the necessary troops. Trenchard was able to offer his small and relatively inexpensive force as a cost effective way to keep dissident rebels in check. In Iraq in 1921, five RAF squadrons were used to replace a ground force of 33 battalions.

\section{$\{\{$ Box 2 Churchill on Air Power $\}\}$}

In this period of peace, it was the ideas of an Italian General, Giulo Douhet, which captured the imagination strategic thinkers. His book, The Command of the Air, was published in 1921 and translated into English two years later. He declared that in future wars whichever side could win in the air would achieve victory. He argued that aircraft had extended the traditional battlefield to include civilian populations, and that attacks should be made on national 
institutions and infrastructure. The effect of such bombing would undermine the population's will to fight as well as disrupting its means to fight. To this advocacy of strategic bombing, he also added the importance of attacking an enemy's air power capability when it was on the ground and vulnerable. His ideas were echoed widely by those who had been involved in the air operations of World War One.

In the United States, General Billy Mitchell was making himself well known with the public, but unpopular with his military colleagues, for his strong advocacy of air power. In 1921, he provided a practical demonstration of the sinking of a captured warship by air attack, followed two years later by two more high profile test attacks and sinkings. But it would be another 20 years, before the United States discovered at Pearl Harbour that it was as vulnerable as Billy Mitchell had predicted. He railed, as successive airmen have, against the inefficiencies of air power being shared between the Army and the Navy. He was court-martialed in 1925 (Douhet had suffered a similar fate in 1916), but undoubtedly motivated the US Navy towards the development of aircraft carriers.

If the victorious powers of World War One were investing little in military air power, this was not true elsewhere in the world. The defeated Germany was notionally constrained in the development of military capability. However, the importance of air power was recognised and was developed initially secretly in co-operation with the Soviets. The Luftwaffe came in to being in 1935 as an independent service with a different philosophy from the strategic bombing doctrine of the Trenchard, Mitchell and Douhet. The Luftwaffe was primarily trained and equipped to attack enemy forces in the air and on the ground and at sea. It was designed to concentrate firepower to disrupt and destroy the opponent's military capability. The German doctrine of blitzkrieg required early and massive air power to be brought to bear on the enemy's combat forces. Japan developed its own military air capability, which was used to great effect against China from 1931 onwards. In particular, by 1937 they had a capability for long range bombing missions. They developed a technique for forward refuelling airfields to extend the range of their fighter aircraft. 
Civil Aviation and Minor Wars Drive Progress

For the USA and the rest of Europe, the advances in air power technology in the inter-war period were driven more by the growing civil interest and enthusiasm for flying than by the worries of air-minded strategists. Air races accelerated the developments in engines and airframes. Altitude record breaking attempts were just as important. In 1920, the USA had achieved 33,000 feet and in 1938, Italy held the record at 56,000 feet. Similar progress was made in extending the range of aircraft: the French achieved just under 2000 miles in 1925, while the British had broken 7000 miles by 1938. Everywhere was potentially within bombing range. There were also real operations for nations to test their new capabilities. The Japanese air operations a jainst the Chinese received little attention in Europe, but allowed the Japanese to develop their air doctrine significantly before World War Two. Of greater significance was the SpanishCivil war from 1936 to 1939. As well as the Spanish air force, Soviet, German and Italian air power was in action. The Soviet force was some 1500 aircraft, but they were inaccurate as bombers and also vulnerable to German fighters. The German Luftwaffe exercised their doctrine of joint operations in support of ground forces to great effect. They were also able to bring in new tactics where necessary. Tactical battle formation flying rapidly replaced tight display formations. Air power was integrated into ground operations with the use of forward air controllers. Concentration of strategic bombing for maximum effect was tested.

As war broke out in 1939, Germany was better prepared with good aircraft and experienced crews who had developed air power as a key part of their military doctrine. In Britain, the late build up of capability, and the focus on bombers, had left the air defences less than comprehensive. Nor was there much agreement within the RAF, or beyond, on the most effective employment of these scarce resources.

World War Two: Air Power affects every campaign 


\section{Learning by Combat Experience}

In the six years from 1939-1945, every theory of air power was put to the test and modified, and all the main roles of modern air warfare were exhaustively exercised. World War Two was a new type of war in terms of communications, speed and extent. Air power had made every civilian potentially vulnerable, and had taken away the safety of dispersal and distance. Yet the promises of technology were often found wanting, and each new technological development was matched rapidly by a counter move. Radar made air defence practical, but was soon degraded by counter-measures.

In popular images of the war, the Battle of Britain remains the most memorable of air campaigns. Britain had only limited numbers of air defence fighters. In August 1940, the German bombers and escorting fighters outnumbered the defenders by about 3 to 1 .Following their philosophy of using air power to attack military capability, the German bombers targeted ports, airfields and British fighters. The RAF senior leadership was divided over the best defensive tactics. By the end of the month, Germany was targeting the radar stations and command centres successfully. German offensive counter-air operations were working, and the British air defence system was being defeated. On 7 September 1940, Germany, believing it had won control of the air switched its bombers to strategic targeting of London. This allowed the British air defence system to rebuild and fight back. Future strategistshave taken the lesson that air superiority lasts only as long as enough air effort is devoted to it. Unlike the permanent seizing of ground by advancing armies, the battle for airspace control must be continued day after day.

A less well publicised, but as important, aspect of the air war was the Battle of the Atlantic. Britain was dependent on supplies being delivered by convoys across the Atlantic. German submarines were increasingly successfulin sinking these ships. Allied air cover was able to reduce these losses considerably, but it was difficult to obtain the priority for scarce air power resources. The strategic bombing of Germany was believed to be a more important task for long range assets. 
The strategic bombing campaign encapsulates many of the weaknesses of the strategic thinking of the inter-War years. Proponents had overstated the psychological effecton populations, and had also expected far more technical capability from bombing systems than was achievable. The nature of the bombing escalated as the war continued. The British began the war by dropping leaflets and ended it by destroying cities. Again there were differences of view between Commanders over which targets, military, industrial or civilian were likely to be more productive in winning the war. The poor bombing accuracy compounded the difficulties.Arthur Harris, the Commander-in-Chief of Bomber Command, was an ardent proponent of the area bombing campaign, but found himself increasingly in dispute with the RAF leadership who sought more precision attacks against what they assessed as key targets.

On the other side of the world, the Japanese showed that it was possible to use air power to provide tactical surprise. The attack on the US fleet at Pearl Harbour in 1941, and the subsequent Japanese victories in the Philippines and Singapore showed how well they had developed their offensive air power capability.In strategic terms, the results were less helpful: the United States entered the war and ultimately defeated the Japanese. The industrial might of the USA was able to outproduce Japan and Germany. By 1945 the US could field 18,000 aircraft against fewer than 5000 Japanese.

\section{Air Power Leaders}

All the combatants were learning that control of airspace was vital to survival, but that air power did not provide the magic path to quick victory. It was at its most effective when operating closely with the appropriate surface forces. Air power could provide extended reconnaissance, defend against enemy air attack, disrupt enemy supply lines, halt an enemy advance, and take out a difficult target. The concentration of firepower in time and space that was possible could be very effective in turning a ground battle. However, aircraft could not hold territory or maintain the continuous presence of armies. Nor could they transport the weight and volume of cargo of surface ships. Combat air power was expensive, always scarce but always needed. The setting of both 
strategic and tactical priorities for air assets was the most important aspect, and it took time to learn through mistakes.

While military thinkers are more vocal in peacetime, it is clear that there were some whose ideas were key to air power utilisation in World War Two.

Winston Churchill perhaps gets too little credit for his lifetime appreciation of what air power means to warfare. It was he that had been at the centre of British air power developments in the previous war. He had warned of the implications of German air power for British security in the 1930's. As Prime Minister he was able to determine both strategic priorities and the aircraft production to support those tasks. In Germany, Hermann Goring had been a famous operational air commander in the First World War, and rose to be the first and only Marshal of the Reich under Hitler. While this helped the Luftwaffe greatly with resources, Goring lacked the vision of Churchill, and the Luftwafferemained tactical rather than strategic. The Soviets had taken air power seriously from the early days of the revolution. However, the Soviet Air Force suffered greatly from the loss of experience when Stalin purged the Red Army Command in 1937. It was further undermined by the priority that Hitler gave to its destruction in 1941. Stalin drew the lessons for the post war importance of strategic air power. In Japan, Admiral Isoruku Yamamoto had progressed from chief of navy aviation to become Commander-in-Chief.He had been instrumental in the design of the Japanese aircraft carrier fleet, and was the driving force behind Japan's approach to maritime air power in the Pacific.

World War Two marked the birth of the USA as the air power nation. It had been surprisingly indifferent to pre-War air power enthusiasts, and had contributed little in the development of strategic thinking. Billy Mitchell's failed attempts to obtain a separate air force had left air doctrine as no more than a part of either army or navy force development. Nevertheless, in a later parallel to Trenchard's career, General Hap Arnold rose through the US army ranks to become the father of the US Air Force. He was a follower of Douhet and the key air power adviser to President Roosevelt. Winning the war in the air required enormous and sustained industrial production capacity, a pool of well educated recruits as airmen and a strong research base to develop new technologies. The 
USA was ideally placed geographically, economically and culturally to meet these criteria. It has maintained its pre-eminence ever since.

In the closing days of the war, the Douhet theorists were given a new lease of life as the US dropped two atomic bombs on Japan. The nuclear age was born and air power now appeared the ultimate guarantor of victory.

Air Power through the Cold War

Air Power and nuclear deterrence

If the atomic bomb was to dominate strategic thinking for the next half century, the jet engine and the missile were also set to transform the mechanics of air power. All three technological developments had been deployed in the latter days of World War Two, but there was limited experience on which to extrapolate the potential consequences for air power. Despite the whole range of air power tasks having contributed to the war effort, the post-war focus for the victorious powers was on development of nuclear weapon delivery capabilities. Yet very rapidly, a non combat form of air power was to prove critical in the growing confrontation between the Soviet Union and the West. Berlin, blockaded by the Soviets in 1948, was sustained by a unique allied air transport re-supply operation throughout .

\section{$\{\{$ Table2 Air Power Roles $\}\}$}

The Korean War (1950-1953)was a reminder that conventional wars with limited aims remained possible in the nuclear age. Jet aircraft were available in numbers for the first time, but had to operate in a confined airspace. A limited war meant political constraints on targets, and as a result strategic bombing of China was ruled out. The lessons of joint operations were re-learned, and for the United States there was a large expansion in their recently (1947) independent air force. Again, the value of flexible air support to troops on the ground was demonstrated in what was a very difficult ground campaign. The helicopter was beginning to be used as a useful improvement to mobility in the difficult terrain found in a series of such limited wars. The British undertook 
operations in Malaya and the French in Indochina. The Israelis were developing a serious air force to defend their newly independent country. However all three nations were reminded of their limitations in the Suez operation of 1956.

Yet for the United States, the Soviet Union and the United Kingdom the key air power role was that of the nuclear bomber. Resources were poured into aircraft and weapon development and production. Conventional weapons were of secondary importance in the battle for funding, despite the growing experience of the need for limited war capability. In the US, General Hap Arnold wrote a memo in 1945 arguing that in future the only defence possible was to field an overwhelming strategic offensive force as a deterrent to any aggressor. He outlined many of the detailed arrangements that were to shape strategic nuclear forces throughout the Cold War. Academic and political thinking about deterrence was also developing in parallel, and is covered in the next Chapter. On the military side, General Curtis Le May, who commanded the USAF Strategic Air Command from 1948 to 1957, built a vast strategic bomber force which far exceeded the capability of any other nation. He shaped the detailed arrangements which ensured that the theoretical constructs of nuclear deterrence could work in practice. The Soviets and the British also progressed in the 1950s, followed in turn by the French and Chinese, with developing long range nuclear bombers. and providing the air defences to protect them from pre-emptive destruction.

Deterrence theorists, such as Thomas Schelling, explored arcane game theory in deriving the required force structure. The RAND Corporation in the USA was greatly influential in the development of Cold War air power thinking. The logic that deterrence depended on the nation being able to ride out a first nuclear attack, and yet still launch a devastating retaliatory nuclear attack became widely accepted. This led to a requirement for large nuclear forces widely dispersed, and a comprehensive national air defence system. Yet even as the bomber forces were being build, another technology was offering more assurance of a second strike capability. Offensive missiles, both air-breathing and rocket powered, had been used by Germany against Britain in the 1940s. In 1959, Bernard Brodie argued in a RAND study, that inter-continentalballistic missiles could provide greater assurance of nuclear retaliation than manned 
aircraft; but that a mixture of systems was even better. In the United States, Robert McNamara brought to the post of Secretary of Defense in 1961 a keen analytical mind. He started the trend for thinking in capability terms when making investment decisions. The nuclear powers have in the years since moved from reliance on manned bombers for nuclear delivery towards greater use of missiles based in silos on land and in submarines at sea. Indeed, the United Kingdom by 1998had abandoned all its other nuclear delivery systems.

$\{\{$ Box 3 Air Power Prophesies $\}\}$

\section{Limited Conventional Wars}

As the Cold War deepened, the focus of air power thinking, in the five declared nuclear powers, continued to be centred on strategic nuclear weapon delivery. In 1957, the United States was beaten by the USSR in the race to place a satellite into orbit around the earth. In 1962, the USA reacted strongly over the deployment of Soviet nuclear capable missiles to Cuba. The building and maintenance of a credible deterrent capability exercised both the USA and the USSR throughout the 1960s.It can be argued that more thinking about the lessons of air power in limited wars would have helped the Americans in Vietnam and the Russians in Afghanistan. The Vietnam war (1964-75)was a savage reminder of the limitations of air power in fighting a guerrilla campaign. It was, however, a period of intense development in conventional air warfare tactics and technologies. Airmobility with helicopter gunship support brought a new level of integration between ground and air forces. While the massive scale of US air power could achieve tactical victories, the strategic victory was more difficult. Escalation of conventional strategic bombing was seen as the way to bring North Vietnam to the negotiating table. Yet again, air power theorists were taught the lesson that conventional bombing does little to make your enemy more amenable. The series of bombing campaigns from 1964 to 1968 added up to 300,000 missions and 643,000 tons of bombs dropped on North Vietnam. The North Vietnamese continued to fight. By the end of the Vietnam war, technological developments allowed much more precise attacks with much lower vulnerability for the bombers. Nevertheless, in the end the US withdrew its forces from Vietnam. Air power theorists continued to argue that 
the defeat was because of the political constraints rather than military inadequacy. However, Korea had already shown the need for operational plans in limited war to take into account the political reality.

If Vietnam and Afghanistan reminded the two superpowers of the limitations of air power in long campaigns lasting years, Israel showed the world the importance of air supremacy in much shorter wars. It had given priority to developing a modern air force which was rightly feared by its Arab neighbours. The Yom Kippur war of 1973lasted only 18 days but provided a wealth of air warfare data of the effectiveness of modern air weapon systems in a classic set piece battle for national survival. The British and Argentineans also learned the strengths and weaknesses of their air power capabilities during the Falklands conflict of 1982.It was a remarkable achievement for the UK, with its very small aircraft carrier force, to wage a successful war at a range of some 8000 miles from home. Subsequently, maritime air power advocates have used this conflict as a strong argument for the continuing importance of carrier-borne air power. Yet the costs remain high and the examples of utility often ambiguous.

While the sporadic examples of real fighting during the Cold War provided justification to air power enthusiasts for a whole range of capabilities, it continued to be the potential NATO/Warsaw Pact confrontation in Europe which determined force structures and technologies. The relatively simple deterrence policy of massive retaliation grew into NATO's adoption of the more complex "Flexible Response", in which the credibility of ultimate nuclear use was enhanced by options to fight a conventional or tactical nuclear war. This allowed operational planners to build up complex scenarios which justified procurement of advanced air weapons systems, which would also be useful in other conventional wars.

By the fall of the Berlin Wall in 1989, air and space military systems had developed beyond the imagination of the early flying pioneers. Satellites could provide imagery of anywhere on Earth, could allow worldwide communications and give a three dimensional accurate location to any military unit. Missiles could threaten virtually instantaneous destruction over the whole of the globe. Bombers could make precision attacks with an assurance of no 
error. Fighters could shoot down the enemy without ever seeing him. Air-to-air refuelling had extended the range of missions across the oceans. Ground attack aircraft and helicopters had become easier to direct than artillery. Defensive and offensive counter-measuresreflected the exciting technological growth of domestic economies. Yet with the end of the Cold War, the theoretical edifice of air power was now much more questionable.

The Air Power Decade 1990-2000

Lessons from the Gulf War

NATO nations raced to reduce their military spending as the threat from the Soviet Union disappeared. There was little agreement on the necessary level that would be needed in the future. Indeed, there were predictions that, without the common threat of the Warsaw Pact, defence would revert to minimum national needs. However in August 1990, before most governments had completed their post Cold War defence reappraisals, Iraq invaded Kuwait. This was a clear breach of international law and was also in an area of considerable economic interest to the major powers. The United Nations imposed economic sanctions, intense diplomacy was undertaken, and this was underpinned by the build up of a US-led military coalition of 29 countries in the theatre. Following failure of diplomatic solutions to the crisis, an air campaign (Operation Desert Storm) was launched against Iraqi forces on 17January 1991. Although massive ground forceshad been assembled nearby in Saudi Arabia, the force commander, General Norman Schwarzkopf, continued a purely air offensive operation for 6 weeks. Precision weapons were used extensively against infrastructure targets. Attacks were orchestrated with appropriate air defence systems, refuelling tanker aircraft and a mix of offensive capabilities. Cruise missiles, with terrain mapping navigation, were used in quantity. Massive area bombing was used against armour in the desert.

On the 24 February, Schwarzkopf assessed the Iraq forces as sufficiently degraded to launch the ground campaign. It was still assumed that there would be a difficult fight to free Kuwait. In the event, the Iraqi forces were routed and Kuwait freed in under 4 days. Air power advocates had found a new role. They 
claimed that modern precision air system in overwhelming numbers would in future win wars, leaving ground forcesthe easier task of moving in afterwards to secure territory. However, even in the Gulf, it was a limited victory. Air operations of various kinds continued against Iraq for the rest of the decade.

While the scale of the coalition for the Gulf War was impressive, it was clear to all that the success depended on American technology, numbers, doctrine and leadership. The USA had emerged from the Cold War as a military power unmatched by any other nation. It was investing much more in defence research and particularly in aerospace and information systems. It appeared that US air power would be the dominant factor in military thinking. However, the very public success in achieving war a i $m$ with few casualties in the Gulf had implications for future operations. US forces were withdrawn from Somalia when 18 of their troops were killed. In the worsening Balkan crisis, the US preferred air strikes to promote agreement in Bosnia rather than contributing troops on the ground.

$\{\{$ Table 3 The modem air campaign $\}\}$

Humanitarian Interventions

The 1990s saw a series of operations, mainly under UN auspices, to try to restore order in failing states around the world. Air power had few answers to mass killings in civil wars in Africa. Where agreements were achieved, such as in Bosnia, the peace could only be maintained by the long term presence of international ground forces. Yet the decade was to finish with a war that was even more important to the air power dominance school of thought. Having come to an uneasy settlement over ethnic divisions in Bosnia, the focus moved to Kosovo. Serbia was increasing its repression of the ethnic Albanian community in this province; the UN and OSCE tried unsuccessfully to negotiate an acceptable peace agreement. For the first time NATO nations agreed, without a formal UN resolution, to use military means to solve a growing humanitarian crisis within a sovereign state's boundaries. The instrument of choice was explicitly solely air power. NATO leaders, when they launched an air offensive on 24 March 1999 against Serbian forces, ruled out an offensive 
ground campaign. Air power was being used to bring the Serbian leadership back to the negotiating table. Over 23,000 bombs were dropped in the ten weeks of operations. From the 38,000 NATO missions flown, there was not a single casualty to the alliance forces. On the other hand, a combination of political constraints on targets, limited poor weather capability and good Serbian defensive measures meant that the military effectiveness of this prolonged air operation was limited. Nevertheless a peace settlement was made in the June, before ground operations became necessary. Again a large international force was needed to police the settlement in Kosovo. Shortly afterwards, Russia followed NATO's example of the use of air power in its rather less surgical approach to quelling rebellion in Chechnya.

While air power studies have concentrated on the offensive operations in the Gulf and the Balkans, a growing need for humanitarian intervention worldwide has had other implications. Rapid response to sudden crises requires deployable forces. Nations are restructuring their military capabilities to provide such forces more easily. Strategic airlift and helicopter lift have in a much quieter way contributed greatly to international responses to crises in Africa and Asia. Planners in defence ministries around the world finished the decade with a much clearer view of the need for the full range of air power capabilities than they had had in 1990.

\section{$\{\{$ Box 4 Air Power Characteristics $\}\}$}

\section{Conclusion}

The twentieth century was one of extraordin ry progress in the application of air power. Most air power forecasters failed to make the right projections. This was scarcely surprising as the technologies advanced rapidly, the tactical implications were poorly understood and the strategic context changed. Air power enthusiasts often overstated the capabilities of their systems, and found it difficult to make their case for resources in opposition to their land and maritime colleagues. Successful air power nations needed a good technological and industrial base, as well as institutional understanding of what air power could offer. 
The surges in practical military utilisation of air power took place in fighting wars of the 20th century. Theorising was extensive in the periods of peace, but was often based on unjustified extrapolation of available data. Airmen were attached to the thinking of Douhet, who saw the control of the air and the bomber as the ultimate weapon system. Yet for much of the century, support of ground forces was the more effectivetask for air systems.

Currently, the United States has an overwhelming military capability which is, to a large extent, based on its modern air power forces. It can carry out precision offensive operations on a world-wide basis from its home territory. It can deliver conventional or nuclear weapons from aircraft or from submarines. It also has the most advanced space and information capabilities, and it outspends all other nations on military research, procurement and deployment. Given this focus of air power, it will be inevitably be a prime influence for all other nations, when looking at their own forces.

Analysts argue whether the air campaign for Kosovo has set a precedent which will mean many more such humanitarian interventions. Some believe the political difficulties of maintaining NATO cohesion mean that it will not be repeated, and that only UN authorised operations will be possible. These are more likely to be at the lower intensity end of the spectrum and thus be less dependent on combat air power. There are still however areas where serious conflict is possible. The division of the Korean peninsular remains. India and Pakistan remain fiercely confrontational over Kashmir, and are both nuclear capable. China has the potential to cause difficulty, particularly over Taiwan. Russia is not yet a stable market economy. Ethnic problems erupt without warning, and sometimes with great ferocity. In any of the possible scenarios, air power is almost certain to have a part to play. However, the costs of air systems remain a problem for all governmentsincluding the United States. There are signs that regional co-operation at providing air capabilities may be the pattern of the future. NATO nations clubbed together to procure an expensive airborne early warning system in the past. European nations are looking at how they might provide such capabilities as intelligence satellites and strategic airlift on a co-operative basis. 
Air power has become an increasing attractive option for western nations, which wish to minimise the risk of casualties to their own forces. This will increase the pressure for the developing air systems and tactics which keep the operator out of harm's way. Unmanned air vehicles will provide some solutions as will greater stand off range for weapon systems. However, the increasing concern about unintended collateral damage will ensure that the man or woman is kept firmly in the decision-making loop.

Military air power began as a form of support for armies and navies. It grew to have strategicinfluence on its own. Many of the problems of developmenthave come from the division of labour between armies, navies and, latterly, air forces. Recognising this, the most recent moves have been towards joint military organisations, which are designed.to makes most efficient use of all resources. This comes just at the time when doctrine seems to be moving more towards the independent use of air power for serious operations.

\section{Summary Points}

- Any successful military operation requires effective control of the air.

- Control of the air is only retained by continuous effort

- $\quad$ Air power relies on advanced technologies, industrial production and skilled manpower.

- Air power is expensive and setting resource priorities correctly is the most important factor for success.

- $\quad$ Air power cannot hold territory.

- $\quad$ Air power provides many politically attractive options for constrained limited operations. 
- $\quad$ Air power must be co-ordinated with sea and land power for greatest effect.

\section{Guide to Further Reading}

Brodie, B., Strategy in the Missile Age (Princeton: University Press 1965)a thoughtful history and commentary on the development of air power thinking from the early days to nuclear bombers.

Douhet,G., The Command of the Air (New York: Coward-McCann, 1942) the English translation of the most influential early air power writer. All students of air power should read this book.

Gooch, J., Airpower: Theory and Practice (London: Cass 1995)a collection of pieces on air power thinking in different nations and useful case studies.

Hallion, R.P., Air Power Confronts an Unstable World (London:Brassey's 1997)an interesting collection of essays from current air power experts on the use of air power in promoting international security in the modern world.

Higham, R., Air Power: a Concise History (New York: St Martin's 1972)a very logical explanation of the first sixty years of air power thinking and practice.

Mason, T., Air Power: A Centennial Appraisal (London:Brassey's 1994) a book which addresses the development of air power, but looks particularly at its applications after the Cold War.

Murray, W., Luftwaffe (Baltimore:N\&A 1985)this is a valuable analysis of the different approach to air power thinking which occurred in Germany after World War One. 
Terraine, J., The Right of the Line (London:Hodder \& Stoughton 1985)a comprehensive and readable history of the Royal Air Force in Europe in World War Two.

Warden III, J.A., The Air Campaign (Washington: Brassey's 1991) the book on the Gulf War by the air planner credited with the development of the new air doctrine which has shaped current thinking.

British Air Power Doctrine AP3000 (London: MOD 1999) a well written official manual of current $\mathrm{UK}$ air power doctrine. This small volume provides an easily understood reader in all aspects of air warfare.

\section{Discussion Questions}

1.Which air power roles can be currently undertaken by unmanned systems, and will more be covered in the future?

2. Is it a good thing that navies and armies operate their own air power systems as well as having an independent air force?

3. Does the experience of the 1990s show that air power is now the main military arm, and that armies have been relegated to a policing role?

4. How can the limitations of air power be overcome?

5. If "rogue states" can threaten mass destruction with long range missiles, are air power resources better allocated to defence or offence?

6. What air power capabilities might the United Nations need for humanitarian relief operations, and should they be permanently allocated to the UN?

7. Do aircraft carriers have an increasing or decreasing role in the future?

8. Which space systems contribute to air power effectiveness? 
9. Is there still a useful role for non-precision bombs?

10. Should nuclear weapon delivery systems be limited to missiles? 


\section{Box 1 Key Concepts}

\section{Air Power}

The ability to project militaryforce in air or space by or from a platform or missile operating above the surface of the earth. Air platforms are defined as any aircraft, helicopter or unmanned air vehicle.

(as defined in British Air Power Doctrine)

\section{Command of the Air}

To have command of the air means to be in a position to prevent the enemy from flying while retaining the ability to fly oneself.

(as defined by Douhet in The Command of the Air) 


\section{Box 2 Churchill on Air Power}

We are sure that if, after a prolonged spell of peace, war on a grand scale suddenly broke out again, the Power which had the most intensive study of aerial warfare would start with an enormous initial advantage, and the Power that neglected this form of active defence might well find itselffatally situated.

Proceeding on this assumption, we contend that the British policy is to develop the independent conception $\mathrm{d}$ the air as an art, an arm and a service; and this method alone will secure that qualitative ascendancy and superiority which the safety of the country requires. We think that to keep this new arm, with its measureless possibilities, in perpetual thraldom to the army or navy, and confined solely to ancillay and auxiliay duties in relation to these two older services, will be to rob it of its most important developments.

Winston S. Churchill 1921 


\section{Box 3 Air Power Prophesies}

In the air are no streets, no channels, no point where one can say of an antagonist:' If he wants to reach my capital he must come by here' In the air all directions lead everywhere.

H.G.Wells 1908

Unlike artillery an air fleet can conduct extensive operations far from, and independentlyof, both Army and Navy. Asfar as at present can beforeseen there is absolutely no limit to the scale of itsfuture independent war use.

J.C.Smuts 1917

Future wars between civilised nations will be strugglesfor life in which entire populations, together with their industrial resources, will be thrown into the scale. Evolution has brought about the creation of airfleets to meet the demands of such warfare.

Sir Frederick Sykes 1919

The air arm is the arm not of a rich people, but of a young people, ardent, bold inventive, who love space and height. It is therefore an arm eminently suited to us Italians. The importance it has attained and its influence on the general character of war arefavourable to us; it is the arm best suited to the genius of our race.

Guilio Douhet 1928 
I think it is well alsofor the man in the street to realise that there is no power on earth that can prevent him from being bombed. Whateverpeople may tell him, the bomber will always get through.

Stanley Baldwin 1932

It is entirely possible that the progressive development of the air arm, especially with the concurrent development of atomic explosive, guided missiles and other modern devices will reduce the requirementfor, or employment of, mass armies and navies.

Hap Arnold 1946

The idea that superior air power can in some way be a substitutefor hard slogging and professional skill on the ground in this sort of war [Korea] is beguiling but illusoy.

Sir John Slessor 1954

We have to assume, on the basis of Korean and World WarII experience, that airforces, like navalforces, will play an ancillay role to groundforces.

Bernard Brodie 1959

Air power, when measured in terms of output per dollar or life invested, is the cheapest, most effective method of fighting in human histo $\mathbf{y}$ - and the advent of precision makes it even cheaper.

JohnA. WardenIII 1997 


\section{Box 4 Air Power Characteristics}

\section{Strengths}

- Flexibility - can be used for a wide range of tasks

- Speed - the fastest way to bring military force to bear

- Ubiquity - not constrained by geography

- Reach - can operate over immense distances

- Surprise - can arrive from anywhere at any time

- Politically attractive - low casualty risk and ease of disengagement

\section{Limitations}

- High Cost - equipment and arrcrew are expensive in time and money

- Vulnerability - dependent on complex base support on the ground or at sea, and on adequate self-defence in the air

- Transitory - air power must be repeatedly applied to maintain effect 
Table 1 Air Power Milestones

1783 Montgolfier brothers' balloon flight

1852 Giffard airship flight

1903 Wright brothers heavier than air powered flight

1907 F.W.Lanchester publishes aerodynamics theory

1909 Wright Model "A" bought as first military aircraft

1910 Ely takes off in a Curtiss biplane from a ship

1911 Lt Gavotti drops bombs on Turks from aircraft

1914 UK deploys anti-aircraft guns to army

1915 Fokker produce forward firing interrupter aircraft gun

1917 Curtiss aerial torpedo is deployed as pilotless aircraft

1918 Formation of first independent air force by the UK

1923 Cierva produces autogyro

1926 Bennett flies over North Pole

1930 Whittle patents the jet engine

1934 Von Braun demonstrates liquid fuelled rocket for German army

1935 Watson-Watt radar successfully demonstrated

1936 Focke-Achgellis helicopter maiden flight

1937 Hindenburg airship disaster

1939 He 178jet aircraft maiden flight in Germany

1940 Battle of Britain

1941 Butement invents proximity fuse

Radar targeting deployed with H2S system

Pearl Harbour surprise air attack by Japanese

1943 Chaff used by RAF to counter German radar defences

1944 V-1 cruise missile and V-2 ballistic missile attacks on UK

1945 Atomic bomb tested and subsequently dropped on Japan

1947 Yeager breaks sound barrier in X-1 rocket aircraft

1948 US B-50 bomber flies non-stop around the world

1949 Berlin airlift

1950 Korean War - jet fighters in combat

1952 Test of first H-bomb by USA

1957 Sputnik 1 orbits the Earth 
1959 US tests first anti-missile missile

1961 USS Enterprise, first nuclear powered aircraft carrier, commissioned

1969 Apollo 10 mission completes manned landing on moon

1970 Laser seeker heads used on bombs in Vietnam war

1976 US Tomahawk cruise missile tested

1982 Falklands conflict includes 8000nm strategic bombing missions

1991 Gulf War introduces prolonged air campaign doctrine

1999 Kosovo air campaign conducted without ground force 
Table 2 Air Power Roles

- Airborne early warning and control

- Air interdiction

- Air reconnaissance and surveillance

- Air to air refuelling

- Anti-submarine warfare

- Anti-surface ship operations

- Combat search and rescue

- Close air support

- Defensive counter-air operations

- Electronic warfare

- Offensive counter-air operations

- Strategic airlift

- Strategicbombing

- Suppression of enemy air defences

- Tactical air transport 


\section{Table 3 The Modem Joint Air Campaign}

The modern air campaign requires hundreds of aircraft from many nations to be co-ordinated in time and space to achieve the mission. Typically AWACs aircraftwill act as the aerial command post keeping a watch for hostile threats in the air. The airfields and aircraft carriers from where the missions are launched will all require their own air defence screens of missiles, guns and air defence fighters. The targets for the attack will have been identified by reconnaissance satellites, aircraft and drones. Attacking aircraft will carry their own self defence systems, but will rely heavily on electronic warfare support aircraft, defence suppression missions using anti-radiation missiles, and combat air patrol fighters. The bombers identify their targets with television, radar or infra red sensors, or will be assisted by laser designation teams on the ground or in the air. The weapons will be guided to the target by laser, television or satellite positioning systems. To extend the range of attack missions and to keep fighters on patrol, large numbers of air-to-air refuelling tankers will circle in nearby friendly airspace. Helicopters will be on standby to rescue any downed aircrew. Once an attack is completed, the reconnaissance force will be retasked to make an assessment of the damage caused and whether the target needs to be attacked again. Naval forces may provide carrier-borne air power and submarine launched cruise missiles. The army may be operating air defence missiles, attack helicopters or controlling incoming bombers with laser designation. 


\section{Arms Control and Disarmament}

John Baylis

The record of Arms Control and Disarmament in the post-cold war era has been a confusing one. In the early 1990s considerable euphoria existed over the opportunities which existed for a major surge forward in arms limitation agreements. The START I and START II treaties, the Conventional Forces in Europe (CFE) agreement, and significant unilateral reductions in Short-Range nuclear forces seemed to launch a new "golden age" in arms control after the disappointments and frustrations of the cold war and pre cold war years. The indefinite extension of the Non-Proliferation Treaty in 1995, the signing of the Comprehensive Test Ban Treaty in 1996 and discussions on a START III agreement appeared to confirm this judgment. At the same time, however, critics of these agreements have questioned their value in an era of friendly relations between the great powers and their sustainability should the climate of international relations change. Difficulties over renegotiating CFE limits to meet changing geo-strategic circumstances, unhappiness in Russia and China over US proposals for a National Missile Defence (NMD) system, together with attempts to modify the 1972 ABM Treaty, and a refusal by the US Senate to ratify the CBT agreement in 1999, reflected a skepticism in some quarters that arms control could be any more successful in the future than it had been in the past.

This debate about the utility of arms control and disarmament policies to reduce the risks of war and contribute to more peaceful international relations is the main focus of this chapter. The first section sets out to define what is meant by arms control and disarmament and to look at the different approaches which each involves. This is followed by an examination of the historical record to test the claim by critics that there is no evidence that arms limitation agreements have ever had a significant impact on peace or war. The third section will look at the arguments in favour and against the utility of arms control in the post-cold 
war era. The conclusion will then sum up the debate and the implications for international security in the future.

\section{Definitions \& Approaches}

While the terms "arms control" and "disarmament" are sometimes used interchangeably, a good case can be made that they reflect very different views about international politics. Hedley Bull, in his book Control of the Arms Race, defines disarmament "the reduction or abolition of armaments. It may be unilateral or multilateral; general or local; comprehensive or partial; controlled or uncontrolled". Arms control, on the other hand, according to Bull, involves "restraint internationally exercised upon armaments policy, whether in respect of the level of armaments, their character, deployment or use".

John Spanier and Joseph Nogee in their study of The Politics of Disarmament provide a similar, although more specific definition of the differences between arms control and disarmament. In their formulation 'while disarmament refers to the complete abolition or partial reduction of the human and material resources of war, arms control deals with the restraints to be imposed upon the use of nuclear weapons'. (Spanier and Nogee, 1962, 15)

Several important distinctions arise from these definitions. Firstly, there is the difference between "reduction" and "restraint". Whilst arm control can involve "reductions" in armaments (and therefore can overlap with disarmament), it can also involve increases if this secures the objective of achieving "restraint" between adversaries. The SALT I Treaty in 1972 is an example of an agreement which sanctioned increases in armaments but at the same time tried to set limits to forces which could be developed in the future. Secondly, the terms reflect a very different view about the causes of war. The theory of disarmament is based on the conviction that armaments are a cause of war. The theory of arms control, on the other hand, accepts that armaments can play a part in heightening tension between states, but sees political tensions between adversaries as the major cause of conflict. For arms controllers the existence of armaments can be a 
source of stability and security if they are managed properly. A third and related distinction is that disarmament has the final objective of abolishing weapons completely and thereby transforming the whole basis of international relations. In contrast, arms controllers do not believe that it is possible either to abolish weapons completely or to fundamentally change the way the world is. All that can be hoped for is to reduce the risk of war, to limit to consequences if it occurs, and contribute to peaceful change. The aims are strictly limited. According to supporters of arms control "adjustments in military postures and doctrines that induce reciprocal adjustments by a potential opponent can be of mutual benefit if they reduce the danger of a war that neither side wants, or contain its violence, or otherwise serve the security of the nation". (Schelling and Halperin)

The literature on disarmament tends to focus on a number of different approaches to reducing and eventually eliminating weapons. For some writers the way forward is to overcome tensions between states through a process of liberal education. According to this view, education can create greater understanding and help overcome the kind of belligerent attitudes which lead statesmen to acquire weapons. Another approach focuses on the political divisions between states. By seeking and achieving a political settlement between hostile states, the need for armaments will be eroded. In contrast, a third approach emphasizes the importance of disarmament itself in helping to achieve more peaceful relations between adversaries. This can either be done gradually, incrementally reducing armament and building up trust until eventually all weapons are abolished. Charles Osgood coined the term "GRIT", (Graduated Reciprocation in Tension-reduction)in the early 1960s to reflect this approach.(Osgood, 1962). Alternatively, there are those who advocate the negotiation of a Single General and Comprehensive Disarmament (GCD) package which will simultaneously bring about peaceful relations by abolishing all armaments at a stroke.

With its emphasis on "restraint" rather than "abolition", arms control theorists tend to draw a distinction between "structural" and "operational" arms control. 
"Structural" arms control is often regarded as the most important of the two because it addresses the quantity and quality of armaments themselves. The aim is to try to achieve "parity" and/or "stability" in the balance of armaments between hostile states. (eg the SALT \& START agreements). In contrast, "operational" arms control aims to contain the behaviour of armed forces by preventing military deployments and actions which may be regarded as provocative, thus increasing the chances of war. Such "operational" arms control measures are designed to help dampen down crises when they occur (the 1963 Hot Line agreement) and to build confidencebetween potential adversaries (the 1975 Helsinki Act).

Despite the important distinctions between arms control and disarmament highlighted by Bull, and Spanier and Nogee, there are some problems in their definitions which need to be recognized. for Bull, arms control involves 'restraint internationally exercised'. What is not clear from this is whether Bull is saying that arms control can only exist between states or whether it can involve restraint within states. The Dayton Accords of 1995 was international, in the sense that a number of states were involved in the Agreement, it attempted to regulate armaments within Bosnia. Similarly, the Good Friday Agreement in Northern Ireland attempted to secure the decommissioning of paramilitary arms within Ulster. What this suggests is that arms control (and disarmament) can be intrastate as well as inter-state.

The definition by Spanier and Nogee is more problematical because it focuses attention specifically on arms control in the nuclear era. The implications of this seem to be that arms control did not happen before the nuclear age and that nuclear arms control is all that matters when it comes to achieving international peace and security. In practice, as we will see in the next section, and the ones that follow, arms control has a long history and even in the nuclear age nonnuclear arms control has been a major and recurring feature of international negotiations and diplomacy. 
$\underline{\text { Kev Points }}$

- Disarmament seeks the abolition of weapons, whereas Arms Control seeks to restrain weapons

- Disarmament sees weapons as a cause of war, while Arms Control sees weapons as both a source of stability and instability

- Disarmers believe that weapons can be abolished and international relations transformed. Arms controllers do not believe that weapons can be abolished or that internationalrelations can be significantly changed.

- Different approaches to Disarmament emphasise liberal education, political settlements, gradual reductions and the need for immediate abolition

- Arms Control can take two forms: "structural" and "operational"

\section{The Historical Record}

In order to understand the relationship between disarmament and arms control measures and assess their success we need to turn now to an analysis of the historical record. For the sake of convenience this record will be divided into four main phases: from 1900 to the Second World War; from 1945 to the early 1960 's; from the early 1960 's to the mid-80's; from the mid-80s to the present.

\section{Phase One: 1900 to 1939}

Although there are some early examples of disarmament ( for example, the 1817 demilitarization of the US-Canadian border), it was not until the late nineteenth and early twentieth century that significant diplomatic progress took place. Tsar Nicholas II was responsible for calling the Hague Conferences of 1899 and 1907 to try to limit the level of armaments. Although a permanent Court of Arbitration was set up as a result of the conferences very little was achieved. In practice, many of the European powers were concerned about Russian motives. It was widely believed that the Tsar wished to cut back on the production of 
armaments largely because of the strain on the Russian economy. Reflecting the lack of trust which was to become a perennial feature of later negotiations, the delegations at the Conferences were also suspicious of the unilateral advantages which they believed others were seeking at their expense. (Gatrell, 18)

\section{Box 1}

\section{Arms Control in History}

'In the ancient world, with endemic warfare and simple weapons, arms control had two purposes. first, it was used at the end of conflicts to create new strategic relationships as , for, example, in the Rome-Carthage agreement of $201 \mathrm{BC}$. Under this the Romans imposed the foedus inaequum, or unequal treaty, on Carthage through which Carthage had its navy eliminated, had to destroy its war elephants, pay reparations, and was forbuidden to undertake any military action in regions adjacent to its home cities. Second arms control was used by political leaders to create or perpetuate stability between their political entities. One such example was the agreement between the Egyptian Rameses 11 and the Hittite Hattusilis 111 following the battle of Qadesh around 1280 BC, to separate their empires by establishing a neutral zone.

During the Middle Ages, arms control was used to only one purpose: to create an orderly state of affairs in the Christian world as in, for example, the Truce of God proclaimed in the Diocese of Elne in 1027. The Truce included a requirement not to fight on the Sabbath, and the penalty for breaking these restrictions was to be declared anathema and faceexcommunication.

The period between the Peace of Westphalia and the Treaty of Versailles, saw the emergence of nation states, the development of the technology of warfare, and the further evolution of attempts to create rules for the use of violence. Arms control was utilizes in three ways. First, it was used at the end of conflicts to create new strategic relationships, as in the Treaty of Utrecht. In order to maintain a balance, under article $1 X$ the French agreed to British demands 'that all the fortifications of the City of Dunkirk be razed, that the Harbour be filled up, and that the Sluices or Moles which serve to cleanse the Harbour be Levelled, and that the said King's own Expense, within the space of Five Months after the Conditions of Peace are Concluded and Signed...'. Second, arms control was used to create or perpetuate stability between states, as in the Rush-Bagot Agreement of 1817, by which the United States and the United Kingdom (subsequently Canada) agreed to the naval demilitarisation of the North American great Lakes..... Third, arms control was used to develop norms of behaviour regarding international violence, as in the Hague Conventions which in 1899 and 1907 set out a series of restrictions on the right to wage war. Examples included prohibitions on the use of poisoned weapons, the killing or 
wpunding of prisoners, and the unnecessary destruction or seizure of property of the enemy.'

Croft, 1986

It took the horrors of the First World war to renew further efforts at disarmament. The Treaty of Versailles represented an attempt by the victors to limit further German aggression by forcibly restricting the armaments it could develop and deploy. Attempts were also made in 1925 with the Geneva Protocol prohibiting the use (but not the manufacture and stockpiling) of poison gas, and with the Kellog-Briand Pact in 1928 to renounce war as an instrument of national policy. One of the most notable set of arms limitation agreements of the era, however, came with the Washington and London Naval Treaties of 1922 and 1930. The Treaties involved a highly complex bargain mainly between Britain, the United States and Japan, in which the parties agreed to:

stop building capital ships for ten years (subsequently extended by a further five years)

a 5:5:3 ratio among their navies

a 35,000 ton limit on capital-ship displacement and a 16 inch caliber limit to the main armament

Although these naval treaties have sometimes been regarded as "a remarkable achievement", it has been pointed out that they did not stop the slide to the second world war. (Gray) For the critics of arms control in general the Washington and London Treaties provide a number of key lessons. The first, and most important, of these is that such agreements can only be negotiated when the international political climate is benign, but they fall apart when the political atmosphere is hostile. In the early 1920sand 1930international relations were conducive to cooperation between states. By the mid-to late-1930s, however, the growing political storm saw both Imperial Japan and Nazi Germany refusing to be bound by earlier arms limitation agreements. 
A second lesson identified by critics is that totalitarian government, not contained by public accountability and the rule of law, often cheat on the agreements they sign. This was true of Germany in the 1920s and 1930s with its secret attempts to overcome the restrictions of the Treaty of Versailles and both Japan and Germany in the 1930s with their open refusal to be bound by the obligations of the Naval Treaties

A third, and related, criticism is that democracies are particularly ill-suited to responding to breaches of arms control agreements. Despite the abrogation of the Naval agreements by Japan and Germany, Britain and the United States were very slow to respond to the emerging threat in the late 1930s. In Britain's case, appeasement rather than rearmament was the initial response. Linked to this is the argument that the actual terms of the agreement tended to tie the hands of the democratic powers to respond in a flexible manner to the rapidly changing circumstances of the late 1930s. In this sense, it could be argued that the agreements helped to diminish international security (at least for the status quo powers) rather than increase it.

Although there were some benefits which emerged following the 1921 Washington Treaty ( the avoidance of transatlantic naval rivalry and Japanese acceptance of the Nine-Power Treaty on China), in general the Treaties did not help significantly to avert war in 1939 and do not appear to have contributed in any meaningful sense to improving the political climate of international relations during the 1930s. (For a slightly different view see Croft, 1996). The same was true of the various attempts made by the League of Nations during the inter-war period to achieve world disarmament. In 1925 the League Council appointed a Preparatory Commission for a World Disarmament Conference which resulted in 1932 in Geneva in the setting up of the World Conference on the Reduction and Limitation of Armaments. With military force once again coming to the fore as an instrument of policy in the 1930s (the 'Devils decade'), however, the Conference proved to be totally ineffective.

Box 2 


\begin{tabular}{|ll|}
\hline The Historical Record I $(1900-1939)$ \\
\hline $1899 \& 1907$ & The Hague Conferences \\
1919 & The Treaty of Versailles \\
1922 & The Washington Naval Treaty \\
1925 & The Geneva Protocol \\
1925 & Prepatory Commission for a World Disarmament \\
Conference & The Kellog Briand Pact \\
1928 & The London Naval Agreement \\
1930 & The World Conference on the Reductions and \\
1932 & \\
Limitation of & Armament \\
1935 & The Anglo-German Naval Agreement \\
& \\
&
\end{tabular}

\section{Phase II 1945-1962}

Following the problems of the interwar period, disillusionment with disarmament and arms control not surprisingly characterized the immediate aftermath of the Second World War. The limited attempts that were made only helped to reinforce the skeptical judgment of the day. The most significant postwar proposal came with the US Baruch Plan in 1946. This was designed to achieve a supervised abolition of nuclear weapons, together with international control of nuclear research and production for peaceful purposes. It was envisaged that the whole process would be controlled by an International Atomic Development Authority. On the surface the proposal looked very promising, but from the perspective of the Soviet Union, it appeared much less attractive. The leaders in the Kremlin viewed it as an attempt to maintain an American monopoly of the knowledge of nuclear weapons. Perhaps not surprisingly, their suspicion of US motives led to a rejection of the Plan. In its place they suggested a ban on the use and manufacture of nuclear weapons and the destruction of the existing (US) stockpiles. They were not, however, prepared to accept any system of effective inspection. This proposal, in turn was rejected by the Americans on the grounds that they would be giving up their nuclear programme without any guarantee that the Soviet Union would not produce a bomb of its own in the future. 
These negotiations on the international control of nuclear weapons represents probably the best opportunity the world community has had to eliminate nuclear weapons. The fact that it did not happen reflects a number of the underlying problems with disarmament as an approach to peace. The proposals, put forward by both the United States and the Soviet Union as their political relationship deteriorated, reflected their own distinctive national interests and also contained a strong propaganda element. Neither side was prepared to take risks with their own security (as they perceived it), especially when it came to weapons which could have a decisive influence on a future conflict. Far from contributing to easing the growing tension between the two powers in the late 1940s, the international control negotiations only helped to exacerbate mistrust and heighten hostility.

Much the same kind of lessons characterized disarmament negotiations during the first half of the 1950s. The first Soviet atomic test in 1949was followed by the first American thermonuclear test in 1952 and a similar Soviet test in 1953. Against this background of these very rapid technological developments a 'parallel monologue' took place in the early 1950s on a range of far-reaching multi-stage disarmament plans. Both sides focused on the issues that affected their security interests most, proposing cuts in those areas where they were inferior to the other. As a result no progress was made.

By the mid-1950s the lack of success in disarmament negotiations and growing awareness of the dangers of nuclear war caused a recognition that a change in approach was needed. It was increasingly evident that the chances of the super powers agreeing to a comprehensive disarmament treaty were slim. As a result attention began to be focused on what were known as 'partial measures' designed to deal with specific problems. Faced with growing anxieties about surprise attacks President Eisenhower proposed an 'Open Skies' arrangement in 1955 which would break down the secrecy and distrust which existed by allowing aerial inspection to ensure that aggressive actions were not being prepared. This was followed by negotiations in Geneva on a nuclear test ban, proposals for atomic free zones and disengagement plans designed to reduce 
forces in certain critical areas like central Europe (for example, the 1957Rapacki Plan).

This move towards greater flexibility at the policy level led to what has been described as 'new thinking' within the defence community. Although the ideas that emerged were not as original as the proponents sometimes claimed, a new literature began to appear in the late 1950s developing the theory of arms control. In contrast to the literature on disarmament the writing on arms control largely questioned the feasibility of general and comprehensive disarmament and argued that greater international stability could be achieved by more effective arms management. Attention was focused on the mutual interest which existed between the super power adversaries to avoid nuclear conflagration. This approach was summed up in the work of Schelling and Halperin. They argued that arms control included:

'all forms of military cooperation between potential enemies in the interests of reducing the likelihood of war, its scope and violence if it occurs, and the political and economic costs of preparing for it. The essential feature of arms control is the recognition of the common interest, of the possibility of reciprocation and cooperation even between potential enemies with respect to their military establishments. Whether the most promising areas of arms control involve reductions in certain kinds of military force, increases in certain kinds of military force, qualitative changes in weaponry, different modes of deployment, or arrangements superimposed on existing military systems, we prefer to treat as an open question'.

The aim was to focus on those 'most promising areas' of arms limitation which might involve reductions in armaments, but which might equally involve new arrangements at higher levels if that helped to make war less likely. The purpose was to work within the prevailing system of nuclear deterrence rather than to try to abolish it. Arms control was designed to "strengthen the operation of the balance of military power against the disruptive effects of the arms dynamic, 
especially arms competition, arms racing and technological developments that tend to make nuclear and non-nuclear deterrence more difficult" (Buzan and Herring, 212). The essential aim was to make deterrence work better through managing armaments and thereby enhancing stability.

During the late 1950s and early 1960s there were still residual attempts to achieve General and Comprehensive Disarmament (GCD). Khrushchev put forward a plan for 'total disarmament at the General Assembly of the United Nations in September 1959. This led to the McCloy-Zorin talks in 1961 which culminated in 'Agreed Principles' in 1962 and a draft plan for General and Comprehensive Disarmament which was later discussed by the United Nations Eighteen Nation Disarmament Committee in Geneva. Like similar earlier talks, however, this plan came to nothing. In contrast, some impetus was given to the 'partial measures' approach by the Antartica Treaty of December 1959 which prohibited all military activities in this particular region. The Antartica Treaty was of significance because it set the scene for a number of 'other preventive' arms control agreements which were reached in the following twelve years (eg the 1967 Outer Space Treaty and the 1971 Seabed Treaty).

Box 3

The Historical Record II (1945-1962)

\section{Phase III 1962-1985}

Even more impetus to the arms control project was given by the Cuban Missile Crisis in October 1962. As the superpowers edged back from the nuclear abyss both realized, more than ever before, that they had a mutual interest in more 
effective crisis management. The crises highlighted the dangers of misinterpretation during periods of intense political instability. In June 1963 the United States and the Soviet Union signed a 'hot line' agreement to provide a secure and instant channel of communication between the leaders of both states. Four years later, during the Arab-Israel war, the hot line was used for the first time to achieve reassurance and prevent the crisis from dragging in each of the superpowersin support of their respective allies.

The Cuban Missile Crisis also concentrated the minds of the key decision-makers on the issue of nuclear testing. Despite previous negotiations and periodic moratoria on testing in the 1950s, it had not proved possible to secure a lasting agreement. In line with the less ambitious agenda of the new arms control school, the US, Britain and the Soviet Union agreed on a Partial Test Ban Treaty in August 1963. The treaty prohibited all nuclear tests in the atmosphere, but allowed tests to continue underground. There was also an escape clause inserted in the Treaty which allowed testing to be resumed after a period of three months notice. This was designed to protect signatories who felt threatened by future technological advances or cheating. Significantly, neither France nor China (who tested nuclear weapons in 1960 and 1964 respectively) were prepared to accede to the Treaty because they felt it benefited the more advanced nuclear states.

Limited as the Treaty was, it did help to encourage further development in arms control. Between 1963 and 1968 the superpowers focused their attention on their mutual interest in trying to negotiate a wider agreement which would prohibit further nuclear proliferation. This culminated in the Non-proliferation Treaty being signed in July 1968. Once again China and France refused to sign, and a number of other states rejected the treaty on the grounds that it froze the nuclear status quo and involved only a limited commitment by the nuclear powers to give up their own weapons.

The nuclear explosion by India in 1974, ostensibly for peaceful purposes, highlighted some of the weaknesses of the Treaty. Despite this, the Treaty provided some limited, but not unimportant benefits. It became the central 
plank in the subsequent development of a non-proliferation regime which helped restrain the pace of further nuclear proliferation. It also emphasized the opportunities for cooperation between the superpowers even at times of political difficulty between them.

This was shown in the aftermath of the Soviet invasion of Czechoslovakia in 1968. Between 1969 and 1972 the superpowers focused for the first time on the difficult task of limiting strategic armaments. In May 1972 the SALT I Agreement was signed covering a number of different areas. These included limitations on anti-ballistic missile deployment ( the Anti-Ballistic Missile Treaty), an Interim Agreement on offensive strategic missiles, and a Protocol dealing with submarine-launched missiles. The aim was to 'cap' missile deployments at certain (increased) levels in order to prevent a future unrestricted arms race which would lead to greater international instability. Despite the unprecedented nature of the agreement, it quickly became the subject of criticism, both within the United States, and in the arms control community itself. For domestic critics of the US government, it froze the numerical superiority of the Soviet Union while at the same time allowing the Soviet Union to compete in those qualitative areas where the United States was in the lead. This failure to address the all-important qualitative issues (including accuracy and multiple warheads) was particularly disappointing even for many arms control supporters who were concerned that the arms race had simply been moved from the quantitative to the qualitative levels.

As a result, it was not long before new negotiations began in Geneva. Progress, however, proved to be very slow. In June 1973Nixon and Brezhnev committed themselves to complete an agreement by 1974 . By July of that year, however, only very limited arrangements had been agreed: to adopt a threshold of 150 kilo tons for underground tests and to limit the deployment of an Anti-ballistic missile system to one site. Neither arrangement was very significant but both sides agreed to continue the process of negotiation. By November a further Accord was reached at Vladivostock between Brezhnev and Ford agreeing ceiling for strategic delivery vehicles (2400) and Multiple Independently 
Targettable Re-enty Vehicle (MIRV) warheads (1320). These ceilings were designed to provide guidance for subsequent negotiations and represented part of the complicated task of defining 'equal security' or 'priority' between the superpowers. Despite the apparent commitment of both sides to move towards a treaty growing difficulties in East-West relations meant that it was not until June 1979 that SALT II was signed. The Agreement eventually reached followed closely the guidelines reached at Vladivostock five years earlier. The ceiling for strategic delivery vehicles were set at 2400 (tobe reduced to 2,250 by 1981); 1320 for MIRVed ballistic missiles and strategic bombers; and 1200 for MIRVed ballistic missiles alone. 
Box 4

\section{The Limitations of Arms Control in the Cold War}

"During the period of East-West arms control between 1963 and $1979 \ldots$ the linkage of arms control to expectations of improved political relations proved to be a greater burden than the arms control process could bear. The process became deeply entangled with political detente, and the state of arms control talks was seen as a barometer of East-West relations. Any positive political influence exerted by the arms control process was easily overwhelmed by the intensifying US-Soviet rivalry in the LICs, growing US resentment at what it felt to be its loss of nuclear superiority, and growing Soviet resentment at what it felt to be a US attempt to re-establish nuclear superiority. Arms control was not able to insulate détente from East-West rivalry". (Buzan and Herring)

Almost immediately, however, the arms control process was derailed by the Soviet invasion of Afghanistan and in January 1980 President Carter asked the Senate to delay the ratification of the Treaty. Although the SALT II remained unratified in 1982both the United States and the Soviet Union agreed to abide by the limits of the Treaty. Despite this tacit agreement, however, the following three years were characterized by frequent accusations by the Reagan administration that the Soviet Union was in breach of the Agreement.

Difficulties in strategic arms control were also mirrored by the lack of progress in other areas during the ten years between 1975 and 1985. Attempts to negotiate a conventional arms control agreement at the MBFR talks became bogged down in complex technicalities and mutual recriminations. Following the Soviet deployment of SS20 missiles and subsequent Western deployment of Cruise and Pershing Missiles negotiations on Intermediate Range systems also served to exacerbate rather to improve international tensions in the first half of the 1980s. (See Box 4) 
Box 5

The Historical Record III (1962-1985)

1963 The Hot-line Agreement

1963 The Partial Test ban Treaty

1967 The Treaty on the Exploration and Use of Outer Space

1967 The Latin American Nuclear Free Zone Agreement

1968 The Non-Proliferation Treaty

1971 The Seabed Treaty

1971 Agreement on Measures to Reduce the Rist of the Outbreak of

Nuclear War

1972 The Convention or the Prohibition of Biological Warfare

\& of

1972 Agreement on Prevention of Nuclear Incidents

1972 SALTI Agreement

1973 The Helsinki Final Act

1973 Agreement on the Prevention of Nuclear War

1973 Start of the Mutual Balance Force Reduction Talks

1974 Vladivostok Accords

1974 The Treaty of Tlatelco (Latin America NWFZ)

1979 Salt 11 Agreement

1985 The Treaty of Rarotonga (South Pacific NWFZ)

\section{Phase Four: 1985 to the Present}

The first signs of change came with the Stockholm Accords in 1986. Following on earlier attempts to build confidence between East and West by the Conference of Security and Cooperation in Europe, the Accords established an important precedent in enhancing transparency between the military blocs and especially by gaining acceptance of the idea of intrusive verification. With Gorbachev's accession to power in the Soviet Union many of the traditional difficulties preventing agreement began to evaporate. A number of writers have argued that during the period from 1985 to 1989 Gorbachev adopted a distinctive strategy of Graduated Reduction in Tension-reduction (GRIT). According to this view, the Soviet leader continuously and persistently put forward initiatives designed to achieve a reciprocal response from the United States and thereby reduce tension. Although this strategy was not altogether successful in achieving the goal of 
reciprocity (especially in the short term) Collins has suggested that 'it is difficult to imagine how the Cold War could have ended if neither superpower had been prepared to take an initial conciliatory step'. He goes on to argue that 'since the impetus for change came from the USSR - from the unilateral initiatives to crucial breakthroughs in treaty negotiations - Gorbachev appears to be the decisive figure (Collins, 1998; see also Box 5).

One of the crucial breakthroughs occurred with the Intermediate Range Nuclear Forces (INF) Treaty in December 1987 in which both sides agreed to abandon the deployment in Europe of all ground-launched theatre nuclear missiles with ranges between 500 and 5,500 kilometres. This represented the first agreement to abandon an important category of nuclear weapons. Building on the Stockholm Accord it also introduced a very intrusive verification regime to support it. George Shultz, the US Secretary of State has argued that the Treaty came at a crucial time in the period leading to the end of the cold war.

"The INF treaty... was a watershed agreement, not only because of its terms but also because it showed that large-scale reductions in nuclear weapons were possible: the United States and the Soviet Union could work out a complex problem of great importance". (Shultz, 1130-1)

Box 6

\section{Unilateral (GRIT)Initiatives bv Gorbachev 1985-1989}

April 1985 Proposal to halt deployment of Soviet SS-20 missiles in Europe. October 1985 July 1985 January 1986 January 1986 years. August 1986 October 1986 weapons. January 1987 April 1987 May 1988

No. of SS-20 missiles reduced to 243.

Announcement of unilateral moratorium on nuclear testing. Moratorium extended.

Plan announced to free the world of nuclear weapons in 15

Moratorium extended.

Reykjavik Summit - proposal to eliminate all nuclear

Moratorium extended.

Offer to eliminate Intennediate-range nuclear missiles. Moscow Summit - three point plan to reduce conventional weapons in Europe. 


\begin{tabular}{|ll|}
\hline December 1988 & $\begin{array}{l}\text { Announcement at UN of plan to cut 500,000 troops, } \\
\text { including 240,000 in Europe. }\end{array}$ \\
January 1989 & $14.2 \%$ cut in defence budget announced. \\
May 1989 & 500 tactical nuclear weapons to be withdrawn from Eastern \\
& Europe. \\
\hline
\end{tabular}

The ending of the Cold War brought a flurry of arms control activity. Following a number of years of detailed negotiation in 1991 a Strategic Arms Reduction Treaty (STARTI) was finally signed. Instead of imposing limits on increases in weapons START was designed to halt and reverse the arms race. Under the provision of the Treaty the United States and the Soviet Union agreed to reduce their nuclear arsenals to 1,600 strategic delivery vehicles and 6,000 warheads (of which 4,900 would be ballistic missile warheads, with a ceiling of 1,100 ICBM warheads). This was followed by a Treaty on Conventional Arms Forces in Europe (CFE) in 1991, finally overcoming the impasses which had led to more than fifteen years of largely fruitless negotiations in the MBFR Talks in Vienna.

With the disintegration of the Soviet Union, Yeltsin and Clinton continued the momentum of the early post-NATO years with a START II Treaty in 1993. The Treaty involved two main phases. Phase one was designed to run in parallel with the seven year timetable for START 1, with each side limited to between 3800 and 4250 warheads at the end of the period. Phase two aimed to limit both sides to between 3000 and 3500 warheads by January 2003 (including the elimination of all ICBMs). As a result of a Protocol to the START 1 Treaty signed in May 1992, it had been agreed, however, that START 11 would only enter into force once START 1 had been ratified by the US and Russia and entered into force. This also meant ratification by the Ukraine, Kazakhstan and Belarus (UKB). This was eventually achieved in February 1994. The Russians refused to exchange the instruments of ratification for START 1 and its Protocol until the UKB acceded to the NPT as non-nuclear weapons states. This was subsequently achieved in December 1994 when the Ukraine finally acceded to the NPT ( with the Belarus and Kazakhstan having acceded earlier). Following on from the progress made in these negotiations, in May 1995 the US and Russia agreed a 'Joint Statement on 
Transparency and Irreversibility'. As the name implies, this was designed to start a process that would make the reductions that had been agreed irreversible.

After this Joint Statement, however, progress became more difficult to achieve. While the US Senate approved the ratification of START 11 in January 1996, the Russian Duma held back. Concern in Moscow centred on three issues: the Treaty's costs and strategic effects; the need to resolve a new debate over the ABM treaty before agreeing START 11 limits; and growing hostility towards NATO expansion plans. Some of these issues were dealt with (at least in part) as a result of subsequent agreements and the decision by NATO in 1997 to limit expansion for the time being to just three former members of the Warsaw Pact. A START 11 Protocol was agreed in September 1997 which deferred completion of Phase one of reductions from 2001 to 2004 and the second Phase of reductions from 2003 to 2007, thereby helping to defer Russian costs of dismantling its weapons. At the same time, US agreed to negotiate a START 111 agreement as soon as START 11 entered into force. The aim would be to bring the number of warheads down to 2000-2500 by 2007. Also in September 1997, 'Demarcation Agreements' were reached which were designed to distinguish between US work on a theatre ballistic missile defence system against 'rogue' states and a strategic system which would alter the balance between Russia and the United States. It was hoped that these ABM and START-related agreements would persuade the Russian Duma to ratify START 11 and its Protocol. They failed, however, to have their desired effects.

Conventional arms control negotiations also proved to be difficult following the signing of the CFE Agreement in November 1991. The dissolution of the Soviet Union meant that the context of the Treaty fundamentally changed just as it was signed. The task of the negotiators then became how to adapt the Treaty to the new circumstances. Initially this involved trying to persuade the eight successor republics to divide up between themselves the entitlements and obligations of the old Soviet Union. This was achieved in mid-1992 but by mid-1995 new problems arose over the unwillingness of Russia to reduce its forces in the flank zones at a time when it was experiencing difficulties in Chechnya. The issue was 
discussed at the first CFE Review Conference in May 1996 when a new Treaty Map delimiting the boundaries of the flank zones was agreed, giving the Russians more freedom to deploy troops to the troubled region. Despite this agreement, attempts to achieve a more fundamental adaptation of the Treaty proved more difficult. It took until November1999 to negotiate an Agreement on the Adaptation of the Treaty on Conventional Armed forces in Europe in Istanbul because of renewed fighting in Chechnya.

The growing difficulty in making progress in arms control negotiations in the late 1990s was also experienced in a number of other fields. Despite the indefinite extension of the NPT in 1995, significant disagreements continued between the nuclear and non-nuclear states over the pace of nuclear disarmament (enshrined in Article 6 of the Treaty). At the same time the nuclear tests carried out by India and Pakistan in May 1998 demonstrated the fragility of the whole nonproliferation regime. The breakthrough achieved with the Comprehensive Test Ban Treaty (CTBT) in 1996 ground to a halt in late 1999 when the US Senate refused to ratify the Treaty. The Chemical Weapons Convention (CWC) which entered into force in April 1997 also suffered from the failure of a number of Middle Eastern states to join, as well as implementation problems in many of the states that had adhered to it. Similarly, the Biological Weapons Convention (BWC) suffered from the absence of a legally-binding verification and compliance agreement, regarded by many as essential to make it work effectively.Tensions have also arisen in recent years between the United States, on the one hand, and Russia and China on the other, over US proposals to develop a National Missile Defense system which would require a modification of the 1972 ABM Treaty. 
Box 7

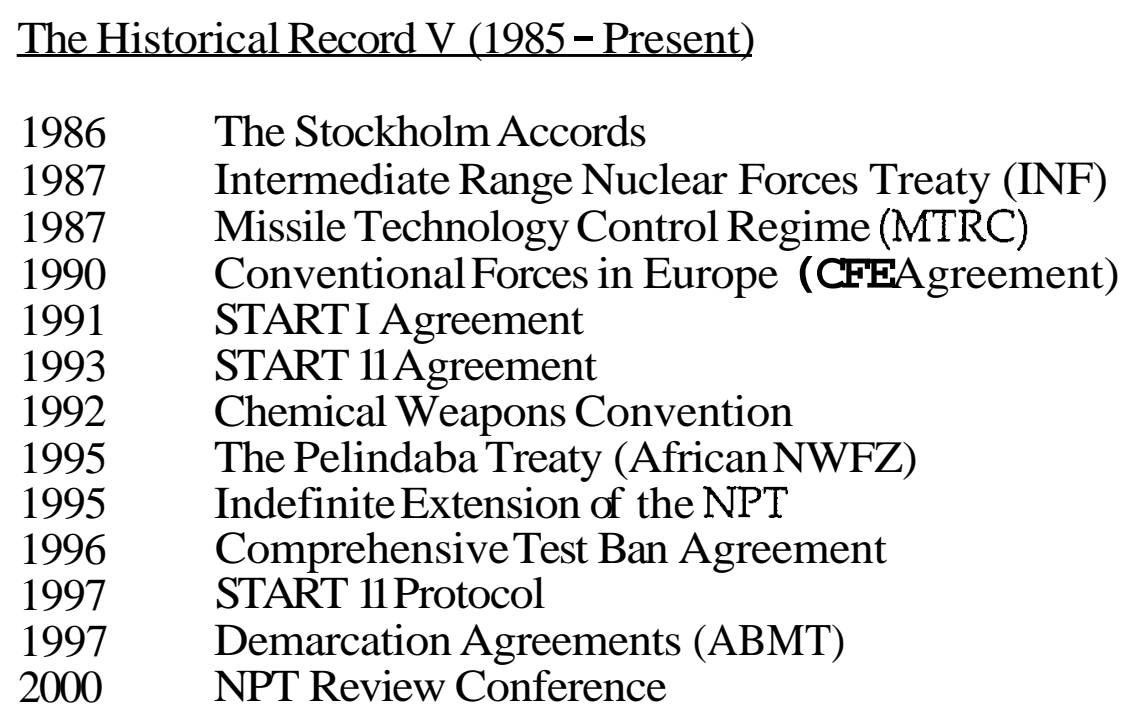

\section{$\underline{\text { Kev Points }}$}

- Disarmament agreements between 1900 and 1939 failed to prevent the drift to war either in 1914 or in 1939.

- The political antagonisms associated with the cold war meant that disarmament proposals between 1945 and the late 1950s were largely propaganda exercises,

- Arms control, as an approach to international security, emerged as a response to the earlier failures of disarmament.

- The aim of arms control from the late 1950s on was to try and mitigate the the instabilities associated with nuclear deterrent policies. 
- Enthusiasm for arms control between 1962 and 1985 brought numerous agreements but were of only limited significance in easing tensions between the superpowers. Often they exacerbated the hostility.

- The period from 1985 to the mid-1990s was a more productive period for arms control and disarmament, leaving some supporters to believe that a new "golden age" had dawned. Recent years, however, have seen growing difficulties over the Comprehensive Test Ban Treaty, START 111, the Chemical and Biological Conventions, and US research into a National Missile Defense system.

\section{The Lessons of the Cold War and Post-Cold War Eras}

One of the key questions about arms control in the second half of the twentieth century is what role it played in helping to prevent war, in contributing to the end of the cold war, and what role it now plays in consolidating the new era of peaceful relations since 1989. It is worth spending a few moments considering two very different judgements.

\section{1. 'Arms Control has been of Crucial Importance'}

For many arms control supporters the fact that war did not occur during the cold war indicates that the agreements reached, especially in the aftermath of the Cuban Missile crisis, performed their vital functions of preventing the outbreak of war between the superpowers. The Hot-line agreement, the Partial Test Ban Treaty, the Non-Proliferation Treaty, and the SALT I and SALT II Treaties all contributed to a recognition that the superpowers had a vital mutual interest in avoiding nuclear war. According to this view, constant technological changes and mutual suspicions inherent in a system of international anarchy help to encourage arms competition which, in turn, pose dangers to international security. By addressing the instabilities of the military balance of power supporters argue that arms control significantly contributed to the absence of great power conflict during the cold war. Even those negotiations that didn't 
succeed, such as the MBFR Talks, are often seen as important events which contributed to greater understanding between the adversaries. Viewed from this perspective arms control has been the 'high road to peace'.

Supporters also argue that not only did arms control help in preventing war but the agreements also contributed in an important way to ending the cold war. According to this view agreements such as the Stockholm Accords and the INF Treaty played an essential part in building confidence between East and West and creating the kind of trust which was crucial to the winding down of the adversarial relationship. Viewed in these terms, arms control was itself part of the process which broke the circle of mutual hostility between the United States and the soviet Union. The agreements reached were not simply a reflection of the improving climate of East-West relations.

Those who support this positive role of arms control also point to the contribution it has made, and continues to make, in enhancing cooperation during the post-cold war era. According to this view, the START I and II Agreements, the extension of the NPT and the signing of the CBT Treaty have helped to reinforce and further develop the trust created by earlier agreements. In this sense, arms control has played an important part in gaining wider acceptance of the idea of 'cooperative security'. The agreements have also helped to lock-in the signatories and make it more difficult for them to return to the kinds of politics they pursued during the cold war. This process will be enhanced, it is argued, by improvements to existing agreements, like the Chemical Weapons Convention and the Biological and Toxins Weapons Convention, and new agreements like START 111 and a Fissile Materials Cut-Off Treaty.

\section{'Arms Control has been Irrelevant'}

The more negative judgement is that arms control played little or no part in keeping the peace during the cold war, that it was insignificant in helping to end the cold war, and that it plays only a marginal role in the post-cold war world. 
Indeed the opponents of arms control argue that the whole concept is fatally flawed. Writing in 1984Louis J Halle put the point in the following way:

'In no other organized endeavour of the nations of mankind has so much work been expended to so little effect as in the efforts to achieve arms control. We must suppose that there has been something fundamentally wrong at the conceptual level to account for so consistent a failure on so large a scale over so long a period.'

According to this judgement the arms control agreements which were reached during the cold war had very little, if any, impact on the prevention of war. Testing continued, despite the Partial Test Ban Treaty; proliferation was not prevented by the Non-Proliferation Treaty; quantitative and qualitative improvements in strategic armaments continued in spite of (and because of) SALT I \& 11; and MBFR wholly failed to achieve conventional arms limitation. Where agreements were reached, the states involved were often able to agree not to do-those things they did not wish to do anyway. Critics also argue that arms control negotiations were often used as a source of propaganda and as such helped, at times, to enhance distrust between the superpowers.

It is often argued that arms control is possible when it is unnecessary, and impossible when it is needed. This is referred to as the "arms control paradox". In the context of the end of the cold war and the post-war era, arms control agreements simply reflect the thaw in the political antagonisms between East and West. INF, it is argued, reflected (but did not cause) the growing rapprochement of the 1980s. Similarly, CFE, START I \& II and the CBT were possible when more cooperative relations existed between the United States and Russia in the 1990s. However, this new political relationship made them largely unnecessary.

Critics therefore see the agreements of the 1990s as being of little importance to the process of cooperation which developed between East and West. They also point to the fact that major problems continue to bedevil contemporary arms 
control negotiations. In the case of the Chemical Weapons Convention and the Biological and Toxins Weapons Convention attempts to secure vital verification procedures have proved impossible to achieve. START 11 and the Comprehensive Test Ban Treaty still await ratification and serious difficulties have emerged over American proposals to modify the 1972ABM Treaty to allow the deployment of a National Missile Defense System. Critics argue that despite the post-Cold war euphoria that the time had finally come for arms control, contemporary negotiations are creating more problems than they are solving.

\section{$\underline{\text { Kev Points }}$}

- Supporters of arms control point to the fact that war was avoided during the cold war and believe that arms control contributed to this. They also believe that arms control agreements contributed to the end of the cold war and are currently helping to maintain more peaceful relations between the great powers.

- Skeptics believe that the concept of arms control is fatally flawed, that agreements did nothing to help avoid war or to help bring the cold war to a close. They also argue that as political relations have improved post-cold war agreements have been unnecessary.

\section{Does Arms Control Make a Difference?}

Which, if either, of these two positions is correct? Is arms control 'the high road to peace' or a 'house of cards'? (Gray) The answer to this question raises very difficult problems for the student of strategic studies. If arms control is designed to 'reduce the likelihood of war, its scope and violence if it occurs, and the political and economic costs of being prepared for it', we have the complex task of assessing how far these objectives have been, and are being, achieved in practice. But how can we establish 'cause' and 'effect'? It is difficult to prove or disprove whether arms control has made or continues to make a difference. If we interpret 'making a difference' to mean making a contribution to initiating and maintaining peaceful, cooperative relations between adversary states or groups. 
how can we decide how significant arms control is in this process? Inevitably, this can only be a matter of interpretation and judgement.

Our discussion of the historical record suggests that the skeptics are nearer the mark. However, to make a more balanced judgement we need to look in more detail at the impact of arms control on a number of key areas. These include:

- International stability

- Norms of behaviour

- Peaceful change

These issues are inter-related, but it is useful to look at each one in turn.

\section{International Stability}

One of the author's of this study has written elsewhere that there is a great deal of 'analytical flabbiness' when it comes to discussing concepts like 'stability'. One of the central tenets of arms control theory is that a $\mathrm{r} m$ control can head-off dangerous developments which arise from arms races and contribute to strategic stability and to crisis stability. This, however, implies that there is a connection between arms races and war and that there are clear criteria for judging 'stability'.

It is not altogether clear that arms races do lead to war. In some cases, such as the first world war, a good case can be made that the competition in armaments building did contribute to the political antagonisms which existed and played a significant part in the outbreak of war. In the case of the arms race between the superpowers during the cold war era, however, clearly war did not result. Whether the nuclear arms race contributed to international instability which was only prevented from escalating into war by arms control agreements is more difficult to judge. 
'Stability' and 'instability' are clearly political rather than military terms, but the politics can be affectedby the armaments which exist, or are planned. Instability is the result of political perceptions, but those perceptions are often formed by past or contemporary military policies pursued by other states. This is reflected in the perennial security dilemma between states. A state believes that its own armaments are defensive while those of others are often seen as offensive. What makes the policies of others appear offensive is a matter of political judgement about the threat which are conditioned by a wide range of issues, including historical animosity, ideology alliance affiliations, as well as contemporary military policies.

In the cold war period arms control attempted to deal with the problems of perceived instability which arose from the military competition between the superpowers. Some of these attempts were successful, most were not. It was felt in the early 1970s that strategic stability (defined in terms of a rough calculation of military parity and what appeared to be a growing consensus about the 'rules' of nuclear deterrence) was threatened by an unrestricted arms race in both strategic offensive missiles and anti-ballistic missile systems. Concern existed that a quantitative and qualitative gap might appear in offensive missiles and deployment of ABMs by one side before the other might undermine the whole basis of the Mutual Assured Destruction basis of deterrence (on which strategic stability was generally believed to rest). The SALT I Agreement in 1972 succeeded in restricting the deployment of ABMs but failed in its attempts to limit offensive missiles because it did not address the problem of qualitative developments. The Agreement therefore enhanced stability in one sense but undermined it in another sense by channeling the arms race into MIRVed technology and creating further distrust as well as uncertainty. Subsequent attempts to try and address the qualitative arms race with the SALT II Treaty failed with the withdrawal of the Treaty from the Senate ratification process following the Soviet invasion of Afghanistan. Both sides agreed to be bound by the Treaty but the deterioration in East-West relations in the early 1980s led to accusations of cheating and non-compliance. Strategic stability was further 
undermined by military doctrines of both superpowers which increasingly emphasized warfighting strategies. These helped to further encourage openended arms competition and played down the search for areas of mutual cooperation.

One of the great concerns during the cold war was that the vulnerability of weapons systems might encourage a surpr se attack during periods of crisis. Arms control was seen as a means of helping to enhance crisis stability. The Hotline Agreement in the aftermath of the Cuban Missile crisis and the late agreement on the Prevention of Nuclear Incidents (1972) were designed to try and achieve these objectives. Such measures seem to have been of some value. For example, they did not prevent the confrontation which occurred in the 1973 Middle East crisis when the US placed its nuclear forces on alert, but the hot-line did help the leaders to de-escalate the crisis.

Arms control has also been used to enhance crisis stability by trying to restructure military forces to make them less vulnerable to attack. The SALT Agreements were somewhat unsuccessful in achieving this objective. START II, however, was more successful in trying to address this question and shift deployment plans away from weapons which were perceived to be destabilizing. Much the same can be said of the INF Agreement, the unilateral decisions to abandon short-range nuclear weapons in the early 1990s and the CFE Agreement in 1991. Although these agreements have been criticized (with some justification), a case can be made that they were designed to overcome some of the dangers which could arise in crisis situations. The INF Agreement and the reduction of short-range nuclear forces were designed to diminish the dangers associated with theatre and tactical nuclear weapons which could have used at an early stage in any conflict which broke out. One of the purposes of the CFE Agreement was to try and reduce the perceived dangers of offensive conventional strategies and surprise attack. Equally, a case can also be made that such agreements were only possible when the climate of international relations was improving. Whether they would/will 'lock-in' states during periods of 
hostility remains much less certain. Arms control, after all, is most needed, but most difficult to achieve, in periods of stormy political weather.

In the early post-cold war period arms control agreements were relatively easy to achieve and helped to enhance the perceptions of stability. As relations between the United States and Russia became somewhat more difficult from the late 1990s the steady flow of treaties dried up. Congress in the United States and the Duma in Russia became less willing to take risks in the interests of international security. Narrower perceptions of national security became the order of the day. As a result, the notion that arms control agreements could enhance international stability was increasingly questioned in national capitals. When the United States put forward proposals to develop a limited National Missile Defense (NMD) system to provide protection against 'rogue' states, both Russia and China perceived the plan as being (ultimately) directed against them. For the United States, the NMD programme and changes to the ABM Treaty were designed to enhance international stability. For Russia and China, these plans were deeply destabilizing because they were likely to re-ignite the arms race between the great powers. Whether a compromise agreement (which reinforces the different perceptions of international stability) can be reached between the great powers, remains one of the great security questions of the day.

\section{Norms of Behaviour}

When judging the utility of arms control much depends on how much is expected of it. Should we seek absolute standards or more relative standards of performance in an imperfect world? Supporters of arms control, with some justification, often argue that the latter is more reasonable. If this is accepted, it can be argued that arms control has played a part in helping to establish and maintain certain norms of state behaviour which has enhanced international security. The 1925 Geneva Protocol on the non-use of poisonous gas, the 1968 NPT, the 1987Missile Technology Control Regime (MTCR), the 1996CTBT, have all been designed to establish regimes to prevent certain kinds of destabilizing developments. 
The problem is that such norms are often weak or only reflect the preferences of powerful status quo powers. It seems likely that the non-proliferation regime will only last as long as it suits the interests of the non-nuclear (but nuclearcapable) states. In particular, it does not appear to have influenced the search by Saddam Hussain for nuclear weapons even though Iraq is a signatory. India nor Pakistan were signatories of the NPT but it seems likely that even if they had signed it would probably not have prevented them from undertaking their tests in May 1998. For India and Pakistan, the NPT was largely a Western device to prevent others from acquiring nuclear weapons while they held on to their own. There seemed to be a rule for one set of (nuclear) states, and a different rule for the set of (non-nuclear) states.

While these criticisms are justified, the establishment of regimes and taboos against undesirable international behaviour are not unimportant. For some, the effects of this kind of arms control are so limited as to be almost worthless. Such a judgement, however, tends to go too far. In the case of non-proliferation there are many reasons why states do not develop nuclear weapons and the regime is unlikely to be decisive in its impact on states thinking about developing such weapons. The regime, however, puts up barriers and increases the political price of going nuclear. While it is impossible to quantify its benefits, the fact that so many states have signed the NPT seems to indicate that for them (and for different reasons) it performs a useful and not unimportant role. The international community clearly feels that the world is a safer place with it than without it - despite all of its imperfections.

\section{Peaceful Change}

Linked to the establishment of certain norms of behaviour is the question whether arms control can contribute to peaceful change in international politics. Once again this is the subject of considerable controversy between supporters and critics of arms control. It also requires a judgement which is difficult if not impossible to prove. 
For the critics, arms control reflects the state of political relations but does not help to shape them. According to this view, there has to be a prior improvement in international relationships before arms control becomes possible. During the cold war there were periods of detente when arms control appears to have played a part in helping to enhance confidence between the adversaries. This happened in the aftermath of the Cuban Missile crisis and in the early 1970s. However, these were short-lived periods and more hostile relations followed. The effects of arms control were clearly limited and temporary. There is very little evidence of arms control significantly helping to improve superpower relations during periods of hostility. Indeed the evidence seems to support the view that differences over arms control more often than not exacerbated the problems which existed. SALT, MBFR and CSCE negotiations were often the occasions for major recriminations between East and West.

In contrast, a rather different case can be made about arms control in the late 1980s and 1990s. While the end of the cold war had many causes, arms control played a limited, but not unimportant, part. The GRIT-type initiatives by Gorbachev between 1985 and 1989 (See Box 5), the Stockholm Accords, the INF Agreements, the START negotiations and progress in conventional arms discussions, all contributed to breaking down the barriers of mutual mistrust between Washington and Moscow. Initially at least, the effects were largely psychological, but no less important for that . For President Bush conventional and nuclear negotiations during this period were 'part of creating a context of progress in East-West relations'. They were an integral part of the process, not independent from it.

This said, there is certainly something in the argument that arms control becomes much easier when the political climate is benign. It is true that it does not follow from this that arms control does not play a part in helping to initiate and then maintain peaceful change once it has occurred. The START \& CFE Agreements, the extension of NPT and the signing of CBT have all helped to continue the process of reassurance and building trust between the former adversaries. 
Unfortunately, disagreements in other areas, over NATO expansion and involvement in the former Yugoslavia, and, as noted above, over American interest in deploying a National Missile Defense system, as well as domestic anxieties in both countries over the ratification of arms control agreements, has led to a faltering of the process of continuing peaceful change in recent years. Political relationships are complex and arms control is only one part of the process which determines how the relationship develops.

\section{$\underline{\text { Kev Points }}$}

- With the possible exceptions of the Hot-Line agreement and the NPT arms control made very little contribution to international stability during the cold war.

- More attention has been given to crisis stability in the post-cold war period. It remains to be seen, however, whether the agreements reached are capable of surviving in a more hostile political environment.

- Depending on one's expectations, a case can be made that arms control regimes do contribute to international security. The norms, however, are fragile and easily flouted.

- Whether arms control contributes to peaceful change remains a highly contested question. Arms control is part of the political process influencing inter-state relations, but not necessarily, or often, a decisive part.

\section{Conclusion}

Even though arms control are part of the political process and can contribute to peaceful change, it does not mean that it is either the decisive element in achieving international (or domestic) security or that it can necessarily prevent or survive a serious deterioration of political relations. An analysis of the reasons for peaceful change in international relations during the late 1980s and 1990s would have to include a wide range of other, perhaps more, important factors, including powerful economic forces, and especially political events in central and eastern Europe. Should relations between the major powers 
deteriorate in the future we should not necessarily expect these states to comply with the agreements they signed in the 1990s. As Colin Gray has argued elsewhere: 'Sovereign states simply cannot be locked into arms control structures that express yesterday's political assumptions and power relations.'

It does not, of course, follow from this that arms control regimes are wholly irrelevant in the search for international security, or security within states. Because the agreements are not universally binding and may not in themselves decisively influence interstate political relationships, especially during periods of hostility, it does not mean that they cannot be a (sometimessignificant) part of a process of achieving and maintaining better relations between states. Admittedly the historical record is not a very positive one and exaggerated claims need to be treated with some skepticism, there is some evidence that not only is arms control perceived to be necessary but, if expectations are limited, that it can have some utility in contributing to international security. It is significant that in the post-cold war era there has been an important shift towards arms control and disarmament in regional and domestic contexts. The Dayton Accords attempted to provide military ratios ( in terms of tanks, artillery, aircraft, helicopters, and armoured personnel carriers) between the Serb Republic, the Bosniak-Croat Federation, Croatia and Yugoslavia. There has been some movement in the task of achieving the decommissioning of arms in Northern Ireland as a result of the Good Friday agreement, and in United Nations efforts to facilitate disarmament in Cambodia, Iraq, Somalia and Mozambique (all with varying degrees of success).

Arms control and disarmament are certainly not a panacea and disappointments certainly await those who put too much faith in the independent ability of arms limitation agreements to transform the basis of international politics. For all their limitations, however, disarmament, and especially arms control, can 'make a difference', especially in building confidence and contributing towards the reduction of tension between adversaries. As such, it seems likely they will remain an important part of the search for greater global security in the future. At the same time, it remains true, that, given their relatively limited 
achievements, states are highly unlikely to rely on arms control and disarmament as central pillars of their security policies. 


\section{DRAFT COPY}

\section{Terrorism and Irregular Warfare by \\ James D Kiras \\ University of Hull}

\section{Opening Summary}

Has the nature of terrorism and guemlla warfare shifted to the extent that it is no longer concerned with politics or political change? In order to address this question, the roots of and assumptions behind historical insurgent and terrorist theories must first be understood. Sparking prairie fires, to paraphrase Mao Zedong, has seemed easy enough to do in theory but vexing in practice. If sparking and sustaining the fire is difficult, quelling it has proven even more so. The practical difficulties faced by governments under siege will be discussed in detail and counterinsurgency and counter-terrorism theory evaluated. Recent irregular warfare commentators have suggested that the strategy of irregular conflict has been transformed fundamentally along with its tactics. Regardless of perceived changes in its nature, irregular warfare and terrorism will continue to be the most numerically predominant forms of conflict for the foreseeable future. This is because irregular forms of violence are often the only practical method by which a weaker party can diminish and overrun an intractable foe to gain political power.

\section{Introduction}

At the height of the period in irregular warfare known as the "wars of national liberation', Robert Taber asserted boldly that 'the guerrilla fighter's war is political 
and social, his means are at least as political as they are military, his purpose almost entirely so. Thus we may paraphrase Clausewitz: Guerrilla war is the extension of politics by means of armed conflict.' (Emphasis in original; Taber, 1970: 26)

Postmodernists and critical theorists, however, roundly reject this explanation of irregular conflict. Martin van Crevald (1991), for example, suggested that warfare itself had transformed into an intrastate cultural exercise devoid of political goals. Therefore, the idea was considered invalid that terrorism and irregular warfare were forms of 'political violence'. The key to understanding current and future forms of conflict was not allegiance to the state or conflicts between them; what matters is 'blood and belonging' (Ignatieff, 1994), or more specifically, a better understanding of the identity and contextual circumstances behind sub-state violence (Munck, 2000). Finally, some authors suggest that technology and ideology has transformed terrorism from an act designed for political effect to wanton mass destruction.

The aim of this chapter is to demonstrate that the spirit of Carl von Clausewitz is still very much relevant to current and future terrorist and irregular campaigns. Historical experience cannot be summarily dismissed. Social, cultural and economic factors do play a substantial role in defining the character and conduct of irregular conflicts. But terrorists and insurgents (and those who fight against them) ultimately seek to achieve a political result from their use of military force. These political results in turn serve goals defined by states fighting insurgencies or those aspiring to change the system through armed conflict.

To illustrate the point, the campaign conducted by the Rwandan Tutsis is an excellent example of the political motivation behind irregular military action. The byproduct of the war in Rwanda, namely the genocide perpetrated by the Hutus, was widely attributed as evidence of the dominance of cultural factors in the "new dark 
age' of irregular warfare. The ethnic animosity between Hutus and Tutsis was a factor contributing to the violence, but the goal of the rebel offensive was the overthrow of the ruling Hutu majority and, ultimately, control of the state. In other words, the expression of 'primordial violence' embodied in the actions of the Hutu army and militias, however morally reprehensible, sought to achieve a policy goal and was not merely violence for its own sake.

\section{Definitions}

The study of terrorism and irregular warfare can be confusing given the degree of subjective interpretation involved. For example, one commentator asserts that more Americans die in their bathrooms every year than from terrorist attacks, whereas the US Federal government spent \$10 billion dollars in fiscal year 1999 on initiatives to protect Americans from something less dangerous than their own bathtubs (Cato Institute, 1996). Obviously there are significant differences in the method of mortality and such contrasts between dissimilar forms of statistics can only lead to misinterpretation. Much of the confusion associated with terrorism and irregular warfare stems from the use of either value-laden or emotive language. 'Freedom fighters' sound appealing and worthy of support whereas the term 'terrorists' conveys cowardly violence, fear and intimidation. 'Guemlla' still connotes a spirit of adventure and romance to rebellious Western youth, evoked by the memory of Ernesto 'Che' Guevara nearly four decades after his death. There is also little agreement on what to call these types of violence: political violence, terrorism, irregular warfare, military operations other than war (MOOTW), low intensity conflict (LIC) [insert Figure 1.1 about here], people's war, revolutionary warfare, war 
of national liberation, guemlla war, partisan war, warfare in the enemy's rear, imperial policing and small wars, among others. As if this was not confusing enough, the effectiveness of terrorist and irregular action is often questioned. Terrorist and irregular campaigns are seen as military nuisances that fail to or rarely achieve their stated political aims without the support of conventional forces. Even worse, critics add, irregular diversions detract from what military organisations do best, namely to prepare to fight against one another.

In order to grasp the fundamentals of a subject as complicated and contentious as terrorism and irregular warfare, it is necessary to provide working definitions of the key terms. Some definitions tend to be extremely inclusive, as in the case of the US Department of Defense (DoD) bewildering outline of tasks that constitute MOOTW:

arms control; combatting terrorism; DoD support to counterdrug operations; enforcement of sanctions / maritime intercept; operations enforcing exclusion zones; ensuring freedom of navigation and overflight; humanitarian assistance; military support to civil authorities (MSCA); nation assistance / support to counterinsurgency; noncombatant evacuation operations (NEO); peace operations (PO); protection of shipping; recovery operations; show of force operations; and, strikes and raids (Joint Warfighting Center, June 1995: III-1).

Alternatively, definitions may be rather exclusive, as in Donald Hamilton's eight-page exploration of the term 'insurgency' and the thirty-eight-page investigation of what constitutes terrorism in Political Terrorism (Hamilton, 1998; Schmid, Jongman, et al, 1988).

For the purposes of this chapter, terrorism is defined as the sustained use of violence by a small groupfor political purposes such as inspiringfear, drawing widespread attention to a political grievance andlor provoking a draconian or unsustainable response. Terrorism does not result in political change on its own, but is undertaken in order to provoke a response. If irregular warfare is the strategy of the weak in order to combat the strong, then terrorism is the strategy of the weakest who 
believe they have no alternatives. What separates terrorism from other forms of violence is that the acts committed are legitimised to a degree by their political nature. Hijacking, remote bombing and assassination are criminal acts but consideration of their legal status can be mitigated if carried out in the name of a political cause perceived to be worthy. The problem exists as to who considers the cause worthy enough, beyond the terrorists themselves, to overlook actions that can be potentially horrific. International sympathy for the plight of the Palestinians, for example, diffused much of the outrage that might normally have been expressed at acts committed in their name such as the Lod Airport massacre in May 1972.The same cannot be said of those responsible for the bombing of Pan Am Flight 103 that crashed in Lockerbie, Scotland. Terrorism has been based on the need to generate domestic and international empathy for a plight that 'drove' the terrorists to arms. Whether or not this remains so is the subject of discussion in the subsection on 'new' terrorism.

Defining irregular warfare is as problematic as defining terrorism for vastly different reasons. Whereas terrorism is an emotive and subjective issue, many believe that irregular warfare is perhaps best understood by first considering what it is not. Irregular warfare is not conventional war or terrorism, for example, but it shares with them the use of force to achieve a political end. The crucial difference is in the form the violence takes. Terrorism seeks to bring awareness to a political grievance but rarely, if ever, results on its own in political change. Irregular warfare, on the other hand, is an attempt to bring about political change by using force of arms. The principal difference between irregular and conventional war is relatively simple: the latter involves adversaries more or less symmetric in equipment, training and doctrine. In an irregular war, the adversaries are asymmetric and the weaker, usually a 
sub-state group, attempts to bring about political change by administering and fighting more effectively than its stronger foe. Individual irregular conflicts differ in character (social, cultural and economic aspects) and type (revolutionary, partisan, guerrilla, liberation or civil wars) but ultimately the ability to wield political power is the desired outcome. Irregular warfare is also characterised by the active and/or passive support and mobilisation of a significant proportion of the population. Coups, however, are not irregular warfare as they are revolutions conducted by a small elite against the ruling elite. Finally, external physical and moral support for an insurgent cause is a prerequisite for success. The point to remember is that these are attempts at functional definitions for the purpose of this chapter and not the final word on irregular warfare or terrorism.

Definitions act as gateways into the areas of study but rarely convey its complexity in theory or practice. In addition, capricious categorisations can lead to a misleading and seemingly irreconcilable divide between forms of irregular conflict. Terrorism and forms of irregular warfare are plainly not the same activity. But how does one then classify the so-called 'urban guerrilla' phenomenon and its ideological impact on terrorist groups during the 1960s? In addition, some terrorist groups adopt parallel efforts that are more commonly associated with insurgencies - have they now become insurgents, do they remain terrorists or have they become something else? The Lebanese organisation known as Hizballah demonstrates the difficulties inherent in assessing irregular conflict. The group was responsible for spectacular acts of terrorism early in its history, including several high-profile kidnappings and the suicide bombings of the US Marine and French compounds in 1983. Yet members of Hizballah fought a protracted guemlla campaign against Israeli forces that led to the latter's withdrawal from southern Lebanon after 18 years. Finally, Hizballah manages 
a substantial number of public service operations largely funded by Syrian backers or monies derived from legitimate and illicit commercial operations. Ultimately, some arbitrary distinctions must be made in order to grasp the business at hand, without losing perspective on the numerous 'grey areas' endemic to the subject.

\section{Subverting the System: The Theory and Practice of Irregular Warfare}

In its most basic sense, those who undertake forms of irregular warfare and terrorism are trying to find a way to use their strengths, such as mobility, organisation and relative anonymity or stealth, against the weaknesses of their more powerful adversary. Bernard Fall reduced this equation even further when he suggested that 'When a country is being subverted, it is being out-administered, not out-fought' (Fall, 1998: 55). But subversion is a time-consuming and resource-intensive activity that does not guarantee success. In almost every case, the length of terrorist and irregular warfare campaigns, successful or otherwise, are measured in multiples of decades as opposed to years. Exactly how to achieve success depends on the local permutations of key factors that eventually make their way from the praxis of the field into irregular warfare and terrorism theory. The factors can be grouped into four 'elemental' headings: time, space, legitimacy, and support.

These elements are not mutually exclusive and excellence in one category will not compensate for drastic shortcomings in the other three. Much like the dimensions of strategy, the elements of a successful insurgency or terrorist campaign are intcrconnected, interdependent and reflect the diâlectical struggle between competing adversaries (Gray, 1999: 23-25). By way of brief excursion, regardless of how just the cause might seem to be and given adequate space and time, a terrorist or insurgent 
campaign will still fail if there is no internal or international support behind it.

Absolute cases, in which an irregular group has none of these elements, rarely occur or last long. The goal for the irregular leader is to strike an effective balance between the elements, offsetting weaknesses in one category with strengths in another and pitting the organisation's strengths against enemy weaknesses. The weight given by different writers to, and perceived relationships between, elements create substantial variations in the theories. The point to underscore here is that terrorist or irregular theories are developed in response to circumstances unique to the conflicts in which they are developed. The result of trying to apply a theory to another conflict, without analysing the differences in context, leads to disaster.

\section{Time}

Time arguably is the most important element required for the successful conclusions of an insurgent and terrorist campaign. Most of the theoretical discourse on the subject reflects the importance of time. But time, much like the other elements, cannot alone win an irregular campaign. In one of the most lucid statements regarding the interactions between the elements mentioned above, Mao Zedong stated simply that his forces had 'retreated in space but advanced in time' (1963). Time is important, in that it allows an insurgent organisation to organize itself, to sap the resolve of its adversary and to eventually build the conventional forces with which to overthrow government. Mao organized the time in his theory into three sequential phases: the strategic defensive, the stalemate and the strategic offensive [Insert Box 1.2 about here]. Each phase, carefully conducted, would lead one step closer to victory no matter how long it eventually takes. Mao understood from his experience 
and reading that the sequence of phases leading to victory was not necessarily linear; friction, in the form of unforeseen circumstances, could lead to setbacks and perhaps regression to a previous phase of the insurgency. But time without victory would eventually lead to the exhaustion, collapse or withdrawal of the enemy. To draw further attention to the interrelationship between theoretical elements necessary for success from Mao, space permits manoeuvre and gives insurgents time to demonstrate their superior legitimacy to the population. With legitimacy over a period of time and given adequate space in which to manoeuvre, internal and external support can be gained. Having gained support, government forces can be weakened further through bolder attacks and a superior army created with which to win decisively.

Most irregular campaigns are not short-term propositions and can remain unresolved for a substantial period of time, as in the case of the 28-year insurgency waged by the Liberation Tamil Tigers of Eelam (LTTE) for political autonomy from the predominantly Sinhalese Sri Lankan state. There have been exceptions to the 'rule' of the long, drawn-out guerrilla struggle, the most famous of which was the Cuban revolution (1967-1969). Led by Fidel Castro against the regime of Fuguenaldo Batista, this irregular war was concluded in just three years but featured incidents and actors of which revolutionary myths are made. A number of factors contributed to the rapid collapse of the government forces; in the vast majority of cases, however, few states are as corrupt, inept and fragile as the Bastista regime in the late 1960s.

Brittle adversaries that allow for a relatively short irregular campaign are few and far between. There may be, however, pressing local circumstancesthat convince the insurgent or terrorist to take immediate action and forego the prolonged struggle. Carlos Marighella believed that circumstances in Brazil in the 1960snecessitated a response other than careful Maoist first-stage planning. The Brazilian Communist 
Party talked about and planned for insurrection but Marighella viewed this as inadequate for a number of reasons. The most pressing reason was time; the Brazilian state grew stronger every month while the revolutionaries continued to talk much but do little. By taking action, Marighella believed that the 'urban guemllas' would build a critical mass for the guerrilla organisation, catch the Brazilian state authorities offguard and provoke an extreme response. In other words, the state of affairs within Brazil required that the relationship normally perceived between the guemlla and time be reversed.

\section{Space}

Space is a prerequisite for a terrorist or irregular strategy to succeed as it gives the advantage to the irregulars to decide where and when to fight. If their adversary appears in overwhelming numbers, irregulars can simply make use of space to withdraw and fight when the odds are in their favour. A defender against sedition cannot be everywhere at once without risking spreading forces too thinly and inviting attack from locally superior guerrilla forces. Space can be considered in two ways: tactically and operationally.

Geographical features, such as formidable terrain that limits the manoeuvre of government forces, are a potent way that terrorists or insurgents offset their relative weaknesses in technology, organisation and numbers. Insurgents have used imposing terrain for tactical advantage, often against foes ill equipped to deal with the challenges presented by mountains, jungle, swamps and even deserts. For example, Afghan Mujahaddin used mountainous terrain as their forefathers did against the British to ambush and limit the mobility of the predominantly road-bound Soviet 
forces. Urban terrain can also be an arduous obstacle as the Russians found in 1994. Chechen guerrillas used buildings and narrow roads to offset their weakness and isolate and destroy Soviet formations during the battle for Grozny. Terrain difficult for government forces provides insurgent forces with the opportunity to establish safe areas or bases from which to expand the struggle.

Space in the operational sense involves consideration of force-to-space ratios. Given the amount of territory to be defended, terrorists or insurgents can partially make up for their operational or strategic inferiority by means of local superiority. In a terrorist or insurgent campaign, the government forces attempt to defend territory or resources that have political, economic, social and / or military value. More often than not, states have the resources to protect local targets but such protection overstretches resources at the national or international level. Lawrence clearly articulated the Arab force-to-space ratio advantage over the Turks during the Arab Revolt (1916-1918). Given the amount of terrain to be covered, Lawrence calculated that the Turks would need 600,000 troops to prevent 'sedition putting up her head' across the entirety of the Transjordan, a figure six times in excess of those available (Lawrence, 1920: 60).

Force-to-space superiority does not imply that the irregulars need a huge geographic area in order to be successful. In the case of the guerrilla campaign conducted against the British in Cyprus, the nationalist group EOKA was limited to a space little more than three percent of that roamed by Lawrence's forces. EOKA's leader, George Grivas-Dighenis, based his strategy on the assumption that substantial numbers of British troops would attempt to put down the insurgency. EOKA members operated in small groups and conducted ambushes, bombings and assassinations. These actions convinced the British that the benefits of remaining in Cyprus were not worth the political price to be paid. 


\section{Support}

Few insurgencies or terrorist campaigns succeed without some form of support. After all, only so much equipment can be manufactured or captured for use by the insurgents. Insurgents must also look after casualties and continually replenish their supplies, including food and water. In addition, they must constantly update their intelligence on the whereabouts and activities of government forces as well as train new recruits. Support, however, is interlinked with and inseparable from the legitimacy of the organisation. Violence conducted without a comprehensible political purpose will generate little popular support. Without support, insurgents and terrorists will eventually succumb to the efforts of the state. Clausewitz suggested that support, in the form of public opinion, was one of the key centres of gravity in a popular uprising (Clausewitz, 1993: 720). There are two main types of support: domestic, or internal support; and, external support

There are circumstances where external support may not be available for either a terrorist group or insurgent movement. Almost all theorists agree that substantial popular support is required to compensate for the resources available to the state. Even Carlos Marighella, who initially advocated that urban guemllas could find and seize the necessary resources in major towns and cities to sustain the struggle, eventually relented and recognized the need to cultivate rural popular support. Domestic support can be forced from the population, using terror and intimidation, but long revolutionary struggles should not rely exclusively on such measures. The role that legitimacy plays in sustaining support will be discussed in the next section. 
Mao's analogy of the support relationship between the guerrilla and the people has almost become clichéd but is still evocative. The guerrillas were likened to 'fish' that swim in a 'sea' of popular support. Remove the sea from the fish and the latter eventually die. A dramatic example of the consequences of failing to have domestic support is the fate of Che Guevara. Guevara believed that conditions in Bolivia in 1967 were ripe for a guerrilla insurrection led by his 'foco' [insert Box 1.3 about here]. One of the supreme miscalculations, however, was on the degree of support to be expected from local Communists and farmers, The Bolivian Communists were hostile to advice on how to run their revolution from outsiders. More importantly, the Bolivian peasants were indifferent to the message preached by Guevara. Although other factors certainly played a role, Guevara and his 'foco' lacked popular support and were either killed or captured within seven months of the first shots being fired.

Support is also contingent on the circumstances prevalent in the individual country. A danger exists in trying to reproduce success elsewhere using a previously effective revolutionary formula without taking into account the basis for support. The uprising of the urban proletariat was considered a necessary in Marxist-Leninist revolutionary theory but failed dismally when attempted in China (1930) and Vietnam (1968). The reason for failure in both cases had much to do with the agrarian character of China and Vietnam, as in both states the majority of the population were rural peasants. As a result, Mao Zedong and Vietnamese General Vo Nguyen Giap respectively modified their strategies.

The other form of support for irregulars - external - largely depends on both the geography of the country and the political relations that the insurgents or terrorists maintain. External support can be physical, in the form of resources or cross-border sanctuaries, or moral, in the case political recognition and lobbying. Many Marxist 
terrorist groups during the 1970s, such as the German Rote Armee Faktion, received physical support from Soviet or client states in the form of money, advanced weapons and training. Insurgent and terrorist leaders in countries ranging from the Dutch East Indies (1950, later becoming Indonesia) and British Palestine (1948, later becoming Israel) received timely external moral support from countries as part of an international backlash against colonialism. External support for irregulars serves political goals of client states, from the weakening of a rival state fighting a proxy war to conducting limited war for limited purposes where the threat of nuclear or conventional escalation is high, as in the example of Kashmir between India and Pakistan.

\section{Legitimacy}

The use of armed force deficient in a moral cause or without reasonable justification is unlikely to be popular regardless of the level at which it is undertaken. Strong democracies can suffer the grumbling of public discontent over the use of airpower in Kosovo but will continue to survive even if another political party is elected as a result. The same cannot be said in the context of terrorism and irregular warfare, where internal or external support is required to sustain the struggle. The leaders of terrorist campaigns, perhaps even more so than insurgencies, need to convey the reason for their actions or lose sympathy for its cause and suffer instead the wrath of the state and its incensed citizens. Terrorist and irregular leaders often seek to legitimise their use of violence and translate this into meaningful support for their cause in a number of ways: demonstrating moral superiority over those who 
represent the state; supplanting the functions of the state at the local level; and, having a persuasive message.

The moral superiority of the guerrillas is a cornerstone of all irregular and terrorist theory. Insurgents derive support from the people and as a consequence it pays significant dividends to cultivate the relationship with them. Mao went so far as to outline a 'code of conduct' for the guerrillas, known as 'The Three Rules and Eight Remarks'[Insert Box 1.5 about here], as a practical method to demonstrate their moral superiority. Almost all theorists agree that moral superiority must be demonstrated in daily conduct so that people differentiate the guemllas from bandits or "counterrevolutionaries'. Che Guevara insisted that the peasants understand that the guerrillas were as much social reformers, or moral and physical arbiters of change, as they were protectors of the people.

Cooperating with the insurgents could bring harsh consequences on the peasants but this could serve to further legitimise the revolutionary cause. Abdul Haris Nasution, military leader of the various Indonesian guemlla actions against the Dutch from 1945-1949, pulled few punches in his description of the true character of guemlla warfare:

It is common practice that an occupation army takes harsh measures against sabotage. Collective punishment, extensive torturing, even the elimination of whole kampongs [villages] and the machine gunning of the people on a mass basis is common. Therefore, a people at war must be prepared for all the consequences so that the people's spirit will remain unbroken and will allow the guerrilla army to launch even harsher measures against the enemy (Nasution, 1965: 35).

Provoking a disproportionate government response would only drive the people further into the arms of the insurgents. The insurgents could then act as the avengers for the people and further cement the ties between them. Or, as Carlos Marighella hoped, the actions of the Brazilian authorities would demonstrate conclusively that the 'government is unjust, incapable of solving problems, and that it resorts simply to 
the physical liquidation of its opponents. The political situation in the country is transformed into a military situation in which the "gorillas" appear more and more to be the ones responsible for violence, while the lives of the people grow worse' (Marighella, 1969).

The niceties designed to demonstrate that the insurgents were better than the government read well on the page but often only applied to those who helped the insurgents. In a number of irregular conflicts, guerrillas and government forces alike equated an unwillingness to help with aiding and abetting the enemy. Absolute popular support can never be guaranteed, as the population will be split invariably into willing assistants, staunch foes and the undecided majority. In order to help make up the minds of those undecided as to whom they will support, without resorting to violent intimidation, insurgents can demonstrate legitimacy by becoming the de facto government in areas under their control. This can include 'positive' measures like the establishment of schools and clinics or 'negative' measures like tax collection. Other negative aspects may be considered necessary to bring a reticent population into line.

The use of terror as a negative measure to intimidate the population is a matter of divisive debate in irregular warfare theory. For Che, terrorism is unjustified as it invariably de-legitimises the guerrilla's message. Both Mao and Marighella disagree, noting that acts of terror may be necessary to convince the population of the occupational hazards of working for the government or to provoke a response. In practice, extensive discussion often proceeded and followed rural acts of terror and the Viet Cong often went to great lengths to provide the justification for their actions during the Vietnam War (1960-1975). Negative measures backed by proselytising can be an effective way of legitimising the insurgent by showing conclusively that the government can no longer protect them. 
The most powerful method of legitimising a struggle, to create considerable internal or external support, is to equate the military struggle with a justifiable political end. Causes vary but self-determinationhas been the most pervasive and successful rallying cry. Given the fundamental rights outlined in the Atlantic Charter (1941) and the United Nations Charter (1945), it was difficult for nations such as Great Britain, France, the Netherlands and Portugal to maintain possession of overseas colonies in the face of native insurgencies claiming the right to selfgovernance. The ideological dimension of the Rhodesian insurgency (1965-1980) aside, few could argue against the cause of black majority rule. More recently, the legitimacy of the East Timorese claim of independence led to internal and external pressure on the Indonesian government to end a 25-year insurgency. Other successful causes blend social, cultural and economic issues into a powerful political message that the government or international consensus finds difficult to counter or resist.

\section{Protecting the System: Counter-insurgency and Counter-terrorismin Theory and Practice}

The difficulties facing governments besieged by insurgents or terrorists may seem insurmountable at first glance but numerous works have been written to explain how to quell them. Counter-insurgency and counter-terrorism works range from general theories and practical suggestions, based on hard-won experience, to complicated empirical models purporting to predict outcomes or test practical advise. In the quest for parsimony and comprehension, commentators have reduced the complicated political-military struggle against forceful usurpers to a number of principles or formulas for success [insert Figure 1.2 about here]. Brigadier General Samuel B Griffith, noted Asian scholar, suggested in his translation of Mao's Yu Chi 
Chan that 'antiguemlla operations could be summed up in three words: location, isolation, and eradication' (Tse-Tung, 1961:32). Griffith's summary is a useful reference point for exploring how to apply the strengths of a state (or group of states) to an irregular threat.

\section{Location}

The most important phase of any counter-insurgency or counter-terrorism campaign is recognising that the threat exists. It is self-evident that there is a problem when car bombs explode or local police stations are attacked for criminal or psychotic reasons. Counter-insurgency expert Robert Thompson believed it necessary to tackle an insurgency during its subversion and organisation phase or at the first signs of a sustained campaign of violence (Thompson, 1967:50). In other words, it is necessary to defeat insurgents in both physical space and time. The problem for counterinsurgents and counter-terrorists is applying the theory to practice or distinguishing between lawful forms of discontent. Restricting guaranteed rights and freedoms every time a bomb is detonated will question the credibility and intentions of the government. Waiting too long to uphold the rule of law, however, will give the insurgents or terrorists the necessary time to build an organisational infrastructure that only the most dedicated efforts stand a chance of defeating.

Terrorism and insurgency can be staved off with enough early warning but this implies an effective intelligence gathering and assessment organisation already operating with a high degree of coordination. Few states possess such resources or foresight and subversion therefore remains an attractive option for the discontented. Those willing and able to destroy the system need to be identified and their 
movements tracked and this requires the assistance of a supportive populace. The question in pluralist systems is whether or not potentially seditious individuals can be taken under surveillance and pre-empted without violating their civil liberties or the rights of others.

Upholding the rule of law is crucial if states are to preserve the legitimacy of their cause and maintain the moral high ground over insurgents or terrorists (Clutterbuck, 1990: 10-11; Wilkinson, 1986: 127). Methods to counter terrorism, for example, must be as unobtrusive as possible. Consider airport metal detectors. They are an example of a method to prevent terrorism while remaining within the boundary of the rule of law. Most of us regard them as an inconvenience and a necessary evil to prevent the smuggling of weapons on-board. More intrusive modem scanners under consideration can show concealed items through clothes. But popular outrage has been expressed at potential infringements upon personal privacy out of proportion to the perceived threat. Managing how and when (and in what measure) to begin counter-insurgency and anti-terrorism efforts, such as imposing curfews and controlling movement, while upholding the rule of law by legitimising the actions taken is the primary challenge to any government under siege. In most democratic societies, however, the initial steps are rarely preventative and almost always after horrific acts of violence have been committed.

Once an irregular threat has been identified from among the substantial ambient noise of discontent prevalent in open societies, the various civil and military agencies must localise the threat while keeping each other informed. On a practical level this means identifying safe houses, group members and sources of supply. Gathering such information about the terrorists can be a daunting prospect, given the desire of most subversives to keep the organisation small, stealthy and secret. For a 
state providing direct counter-insurgency or counter-terrorism support into a geographically and culturally unfamiliar country, as the United States did in South Vietnam, obtaining even basic information on subversives takes time that only allows the insurgent organisation to grow.

\section{Isolation}

The isolation of insurgents and terrorists from their bases of support is arguably the most important aspect of a successful campaign. For counter-insurgents isolation translates metaphorically into 'evaporation' of the Maoist 'sea' in which the guerrilla 'fish' swim. Isolation can be considered in two ways: physical separation and political motivation. Physical separation can be undertaken in a number of direct and indirect ways: removal of villagers into more easily defended compounds, known in Malaya and Vietnam as 'Strategic Hamlets'; denial of access through preventative measures such as curfews, prohibited areas ('no-go' areas) and food rationing; and, aggressive patrolling and overt presence. Like any form of deterrence, the threat posed by patrolling and presence must be a credible one and not consist of 'cordon and search' or 'search and destroy' operations conducted to fulfil quotas, as was the case with US forces in Vietnam. Isolation also means limiting the mobility and range of the insurgents or terrorists, in effect taking away their space and their time. Finally, insurgents and terrorists must be cut off from their external sources of support by a combination of diplomatic pressure and tangible military measures. The French managed to impose the most literal form of isolation from external support upon the Armée Liberation Nationale during the Algerian insurgency (1954-1962): the border 
between Algeria, Morocco and Tunisia was shut down by a combination of wire barriers, guard houses and patrols.

Segregating insurgents and terrorists from the population goes far beyond just physically separating them. In order to impose meaningful isolation, the state(s) must defuse the irregular's most powerful asset: its message. Put simply, those elements that create a potent source of recruitment and support must be addressed by the government(s) on the defensive. Obviously, some messages are more influential than others: self-determination is difficult to counter by an external or occupying power whereas domestic measures such as land reform or increased political representation may be much easier to implement. The words of the government must be accompanied by effective deeds, to show that the state can and will respond to what amounts to political extortion. The terrorist or insurgent 'propaganda of the deed' must be diffused by government displays of firm, yet lawful response. The displays can include measures as stem as enforcing a 'no negotiations with terrorists' policy to relatively simple yet effective measures like improving crop yields or building schools and wells. The onus is on the representatives of the state to prove that they are morally superior to the guerrillas and terrorists and will provide for the needs of their citizens, including responding to the sources of disgruntlement that led to armed insurrection in the first place. Likewise, the terrorist or insurgent cause must be discredited and demonstrated to be illegitimate. Leniency should also be extended to those insurgents and terrorists who give up the armed struggle. Above all, the citizenry must be mobilised and accept that the state's fight is their fight; the security of the population, in other words, depends on their ability to defend themselves. Popular support for the terrorists or insurgents must be denied through credible and efficient actions to win what Sir Gerald Templar called 'the hearts and minds' of the 
population (Insert Box 1.5 about here). With little internal or external sustenance and a population willing to support the government actively and passively, it is only a matter of time and of political will before the forces of the state destroy the remaining irregular threat to its existence.

\section{Eradication}

In its simplest terms, eradication involves the physical destruction or annihilation of the insurgents or terrorists, although few would go so far as to follow Robert Taber's rhetorical advice: 'There is only one means of defeating an insurgent people who will not surrender, and that is extermination. There is only one way to control a temtory that harbours resistance, and that is to turn it into a desert' (Taber, 1972: 11). The state has numerous advantages over potential irregular usurpers given its ubiquitous resources, including political control over social, fiscal and military resources. The most important question in democratic states is whether or not the leaders of the state can apply its resources in a coordinated fashion to extinguish the insurgent flame without alienating popular support. Cultural context matters when determining a response. Canadians, for example, would not approve of measures like the so-called 'Wrath of God' retribution campaign conducted by the Israelis against those responsible for the 1972 Munich Olympic massacre. The methods by which insurgents or terrorists can be eradicated fall into two broad categories: active and passive.

Counter-insurgency theory is rife with active plans that discuss destruction of guerrillas. These plans range from French Marshal Lyautey's innocuous sounding 'oil patch' method applied in Morocco in the first quarter of the twentieth century 
(Gottman, 1948: 248) to the more sinister Nazi German 'spider'sweb' and 'partridge drive' tactics (Dixon and Heilbrunn, 1962:215-216). In order to be successful, all theorists agree that significant resources must be committed to ensure that the insurgents find few safe havens. The accepted force ratio of government military forces to guerrillas is often cited as 10:1. This ratio does not include additional civilian manpower resources. In addition to regular military forces, most theorists state the need for the use of other specialised resources including: some form of special operations forces, or 'guerrillas or terrorists in uniform', to defeat the irregulars at their own game; and, use of technologies not available to the insurgents, such as helicopters and remote sensors, to overcome the force-to-spaceratio deficit and achieve superior mobility.

As insurgencies and terrorist campaigns are first and foremost political in nature, active military measures must be accompanied by positive political efforts to address the grievances at hand and de-legitimise the irregulars. There are also passive ways in which the state can subvert an insurgency and cause numbers of guerrillas or terrorists to dwindle. One such method combines psychological warfare techniques, promises of amnesty (the Chieu Hoi, or 'Open Arms' programme used in South Vietnam) and cash incentives (for weapons and information) to convince insurgents and terrorists that their struggle is in vain. Passive and active techniques are not mutually exclusive and can be combined for significant effect. During the bush war in Rhodesia (Zimbabwe, 1965-1980), for example, a sizeable number of guerrillas were persuaded not only to give up the armed struggle but also to operate against their former comrades. The 'pseudo guerrillas', as they were called, would dress as insurgents and continue to patrol villages, gathering information on the whereabouts of other active guerrilla units. Occasionally, 'pseudo guerrilla' groups would ambush 
guemlla units leading to mistrust and, occasionally, pitched battles among 'friendly forces' (Reid-Daly, 2000). Other passive measures include engaging in political dialogue with, and support for moderates within an irregular organisation and convincing them of the need to start talking and quit fighting.

Regardless of the methods chosen and a surfeit of resources, the political will must exist to see measures through to the end in order to counter successfully terrorism and insurgency. The eradication of an irregular movement is a gradual process of attrition that, as has been mentioned previously, requires a significant and consistent investment in both time and resources. The historical record regarding the number of states whose leaders could sustain the political will necessary to defeat insurgents or terrorists indicates that strategic success is a rarity. Equally daunting is the fact that the underlying causes of discontent often resurface and the embers of insurgency are rekindled in a different form. With US assistance and proactive efforts the government of the Philippines conducted a textbook campaign of how to defeat a communist insurgency during the 1950s. Yet barely a decade later the government of the Philippines was faced and continues to be faced by Muslim separatist guerrillas, like the Abu Sayyaf group, who have sustained themselves with a rather lucrative trade in ransoming hostage. The effects of terrorism can often be limited through a combination of offensive and defensive measures, but ultimately bringing terrorists to justice, especially for crimes beyond state borders, requires significant determination and political will. In the case of the Libyans allegedly responsible for the Lockerbie bombing, it took the US twelve years and a substantial degree of third-party support to bring defendants to trial.

\section{Bringing the System Down or Thriving on its Margins: The Future of Terrorism and Irregular Warfare?}


As outlined briefly in the introduction, the perception that terrorism and irregular warfare involve the use of force for political ends has been challenged recently. Many commentators argue that bringing about political change no longer defines irregular conflict given the new paradigm of the post-Cold War landscape. In other words, wars of national liberation and revolution havejoined colonial small wars in the museum of 'conflict past'; instead irregular threats are and will continue to be driven by a mixture of religious fanaticism, culture, ethnicity or technology.

\section{Religion + WMD = Apocalypse Now}

Terrorists and insurgents often had a religious aspect of their cause and used it to gain legitimacy and support among the faithful, such as Lebanese groups Hizballah or their rivals, the Christian Druze militia. Religion has been a powerful motivating element of political violence. In exchange for sacrificeresulting in the deaths of heathen others, earthly representatives of the faith promise religious terrorists a glorious afterlife. Authors such as Walter Laqueur suggest that threat to Western democracies is more present and dangerous given the availability and desire of religious-motivated groups to use weapons of mass destruction (WMD) such as biological, chemical and even nuclear weapons.

The congruence of religion, WMD and the belief that the end of mankind is nigh (millenarianism) has the makings of a frightful and very real 'apocalypsenow'. Brian Jenkins argued in the 1970s that terrorist use of nuclear weapons was unlikely as 'terrorists want a lot of people watching, not a lot of people dead' (Jenkins, 1987: 352). Modem religious fanatics, it is argued, do not march to a political drum. There is no need, therefore, to convey a message by action. The action is what matters and 
the desired outcome is the purging of the non-believers and the acceleration of 'the end of days'. Other evidence is cited to support this thesis: the ease with which 'poor man's atom bombs', or chemical and biological agents, can be manufactured or acquired; the number of groups that have stockpiled such agents in the past; the decreasing frequency and increasing lethality of terrorist acts; and, the breaking of a so-called 'WMD taboo' by the Japanese religious cult Aum Shinryko in Tokyo in 1995 (Laqueur, 1999).

\section{Warriors, Ethnicity and Non-Trinitarians}

Others suggest that the future of irregular warfare will be over differences in culture, as opposed to religion. Westerners have been used to warfare by established rules in which the combatants grapple with one another to achieve political aims.

Over time we have developed organisations within our society to fight by those rules for us. Recent experience, in places like Chechnya, Somalia and the Democratic Republic of Congo, suggests that Western soldiers will be faced by an inexplicable foe: the warrior enabled by culture. According to this argument, modem conventional forces of volunteer or conscripted soldiers cannot match wamors forged to fight as a part of their culture since birth (Peters, 1994). The availability of modem small arms and a disdain for Western rules of warfare gives the wamors their military superiority. Political aims matter not to Somali clansmen, high on khat, driving around Mogadishu in heavily-armed civilian vehicles. In other words, the warrior culture dictates the goals to be achieved, such as killing to prove virility and plunder, not politics.

Closely tied with and perhaps inseparable from the cultural vision of irregular warfare is the perception that violence will be ethnic or identity-based. According to 
Martin van Crevald (1991), the Clausewitzian trinity of the people, the state and the armed forces no longer exists. States are no longer viable political entities, as they do not represent the will of the people and instead collapse into pockets of conflicting ethnic groups. Without the state the means no longer exist to sustain the armed forces; therefore, the only surviving member of the trinity is the people. Conventional armed forces possess equipment useless in today's wars because it is TOO 6 EFIBUP: too expensive, too fast, too indiscriminating, too big, too unmanoeuvreable and too powerful (Van Crevald, 1989). Major powers will not gain anything from conflict and vested interests exist within the state to ensure high levels of defence spending. Therefore, non-trinitarian sub-state actors will fight for profit and glory and industrialised countries will be unable to come to grips with this new manifestation of a very old form of warfare.

\section{Cyberterrorists, Infosurgents and Lone Wolves}

The last variation on the theme of a radical shift in irregular warfare centres on technology. The Internet transcends borders and therefore future irregular war will be fought in cyberspace. Given the vulnerability of websites and servers to hackers, it will only be a matter of time before terrorists take to the World Wide Web and become cyberterrorists (examples include Serbian and Indonesian hacking of opponent's websites). The evidence of this future is plain to see in the present; the defacing of NATO and other websites is considered to be only a glimpse into what ambitious cyberterrorists can accomplish. The fear is that cyberterroristsand infosurgents will conduct electronic raids on vital national systems controlled by computers, from financial services to transportation networks and power grids. The 
creation of fear by physical means is no longer necessary: information and the ability to control it will become its own form of power.

Accessibility to the Web and the portability modem computer equipment allegedly gives new power to aspiring terrorists and insurgents. With a computer and a connection to the Internet, a single individual can do more damage than the members of the Japanese Red Army during their careers. More importantly, the dream of a functional 'leaderless resistance' (Beam, 1992) can be realised in which secretive individuals or small insurgent cells can share information and coordinate action without a hierarchical leadership organisation vulnerable to penetration and subversion.

\section{Conclusion}

States will continue to be plagued by terrorism and irregular warfare as long as individuals are willing to use violence for political purposes [Insert Figure 1.3 about here - Source: US State Department, Patterns of Global Terrorism 1999, Appendix E: International Terrorist Incidents 1999, http://www.state.gov/www/global/terrorism/ 1999report/752622.gif]. The shocking cultural details of irregular conflicts, such as the use of women and child soldiers in Liberia and Sri Lanka, can distract from the political dimension behind the fighting. That famine has been used as a weapon by the government of Sudan in its counter-insurgency campaign against the Southern Sudanese is undeniable. There are also significant cultural and religious differences between members of the opposing forces. But Sudan's experience is no different from other irregular conflicts. Ultimately terrorism and irregular warfare is about changing the current political system and acquiring the political power to make decisions on issues ranging from tribal representation and language. 
The most significant problem with current re-evaluations of irregular warfare and terrorism is the lack of context: a component part of irregular conflicts is examined at the expense of the overriding picture, namely the reason for the conflict and the desired outcome. The rescue of British military personnel held hostage by the 'West Side Boys' in Sierra Leone in September 2000 was conducted ostensibly to ensure the safety of British nationals. Whether the 'West Side Boys' are harbingers of the 'new wamor class' or merely well-armed bandits is irrelevant. The rescue mission was intended to convey an unequivocal political message as valid today as it was during the punitive British expedition to Sierra Leone in 1899: to paraphrase Charles Callwell, an insult to British national pride would be wiped out, a wrong avenged and in this specific case, to deter other groups from taking British citizens hostage in the future (Callwell, 1899: 8).

Religion, culture, ethnicity and technology have been and will continue to be important aspects of irregular warfare. These aspects define to a degree how and why individuals take up arms against perceived injustices. But the ultima ratio for the use of irregular methods of warfare is to have a political effect that results in political change. A terrorist use of a weapon of mass destruction is a frightening prospect. Yet Shoko Asahara, the spiritual leader of Aum, only attempted to use chemical and biological agents after his political ambitions were thwarted in 1990. Revenge was the motive in response to his humiliation at the polls. Government leaders have subsequently taken the threat of terrorist use of WMD seriously and a number have established at least rudimentary preventative and protective measures to demonstrate competence to its citizenry. For example, the vast majority of US Federal spending on counter-terrorism mentioned at the beginning of the chapter is to establish response mechanisms to the irregular WMD threat. Another category of 'new' terrorists, US 
militia and patriot groups, desire to provoke a response through action in order to redress the political imbalance they perceive between illegitimate federal authorities and individual rights and freedoms established in the Constitution.

Warrior cultures may appear to espouse violence for its own sake but at the root of a number of ethnic conflicts and wars deemed cultural is the ambition for political autonomy, control or power. The recent guemlla war fought by the Chechens against the Russians is no different than that conducted in 1856: the desire of the Chechens is to have political autonomy from the central Russian authority. Somali warlords seek to gain political power and influence for their clans in areas under their control. Native Americans fought against the US Army in the nineteenth century to maintain autonomy and protect their traditional hunting grounds. Even ancient irregulars, classified as barbarii by the Romans, were resisting attempts to have Pax Romana imposed upon them.

Finally, the declaration that the Clausewitzian trinity is dead misrepresents its foundation and misconstrues the reasons why irregulars fight in the first place. After all, primordial violence (the people) serves no purpose unless it is subordinated ultimately to policy (the government). Purposeless violence is nothing more than a criminal act in civil society and should be treated as such. Even when violence is used to fulfil a policy goal, such as replacing or defending the ruling authority through force of arms, the outcome is uncertain. The reason for the uncertainty is that the combatants (the armed forces or irregulars) are prone to the effects of friction until their policy goals are achieved or subsumed.

\section{Key Points}

- Terrorism and irregular warfare is the method by which the weak attempt to bring about political change through the use of violence. 
- Terrorism, more so than irregular warfare, is difficult to define as the interpretation of which acts constitutes

- Guerrilla and terrorist campaigns seek to defeat their superior adversaries through more effective political action through four elements: space, time, support and legitimacy. Military action plays a limited and subsidiary role.

- Political will to see an irregular conflict through to the end is a necessity given the time it takes to wear down an adversary. Irregulars are too weak to conduct a decisive campaign early; counter-insurgent and counter-terrorist forces are almost always aware of the problem when the irregulars have already established a base of support.

- Counter-insurgent and counter-terrorist forces must operate within the rule of law, in an efficient and decisive manner, in order to retain the moral high ground necessary for eventual victory.

- Irregular forces or even other states can be subverted by the use of one's own guerrillas or special operations forces.

- Revisionist views of irregular warfare examine the subject on the basis of its component parts, such as religion, ethnicity, culture and technology, and often overlook the expected political outcome of the violence.

\section{Questions for further consideration}

1. Does the nature of irregular warfare change or merely its characteristics?

2. Can insurgents sacrifice time in order to effect political change?

3. Why is the element of space easy to discuss in theory but difficult to incorporate into practice?

4. Why are irregular warfare theorists divided on the use of terror as a method of compelling support?

5. Why is there no universal theory of irregular warfare?

6. How is the balance struck between the rule of force and the rule of law on both sides of an irregular campaign?

7. Can insurgencies or terrorist campaigns succeed without the assistance of conventional forces?

8. Does the message matter in 'new' terrorism? 


\section{Box 1.1}

\section{T.E. Lawrence on Irregular Warfare}

The influence of the writings of Thomas Edward Lawrence (1888-1937, better known as 'Lawrence of Arabia') to the development of theory on irregular warfare cannot be overstated. Many future practitioners of the trade, from Mao Zedong to German special operations expert Otto Skorzeny, acknowledged the debt they owed to Lawrence in the development of their own thoughts. A quixotic character whose historical impact still remains the subject of much controversy, Lawrence nevertheless managed to explain lucidly in less than 250 words the essence of a guerrilla struggle:

'It seemed that rebellion must have an unassailable base, something guarded not merely from attack, but from fear of it; such a base as we had in the Red Sea Ports, the desert, or in the minds of men we converted to our creed. It must have a sophisticated alien enemy, in the form of a disciplined army of occupation too small to fulfil the doctrine of acreage: too few to adjust the number to space, in order to dominate the whole area effectively from fortified posts. It must have a friendly population, not actively friendly, but sympathetic to the point of not betraying rebel movements to the enemy. Rebellions can be made by 2 per cent. active in a striking force, and 98 per cent. passively sympathetic. The few active rebels must have the qualities of speed and endurance, ubiquity and independence of arteries of supply. They must have the technical equipment to destroy or paralyse the enemy's organized communications, for irregular warfare is fairly Willisen's definition of strategy, "the study of communication" in its extreme degree, of attack where the enemy is not. In fifty words: Granted mobility, security (in the form of denying targets to the enemy), time, and doctrine (the idea to convert every subject to friendliness), victory will rest with the insurgents, for the algebraical factors are in the end decisive, and against them perfections of means and spirit struggle quite in vain.'

Lawrence, T.E. (1920), 'The Evolution of a Revolt', The A m y Quarterly, 1(1), 69. 


\section{Box 1.2}

\section{Mao Zedong, China in the 1930s and the Three-Stage Theory of Insurgency}

Mao Zedong (1893-1976) received an education, which was a rarity in China at the time. His first job after graduation was as a librarian at Peking University in the year of the October Revolution in Russia (1917). Mao was an avid reader and began his revolutionary career as a peasant agitator, joining the Chinese Communist Party (CCP) in 1921. The CCP was working towards expelling foreigners and 'gentry' landowners. In 1928 the Chinese Nationalist forces (Kuomintang)went on the offensive and scattered the CCP. The few remaining 'comrades' retired to the mountainous Fukien-Kiangsi area and rebuilt. In the wake of a disastrous urban revolution in 1930, Mao developed a theory on how best to conduct irregular war in China. Chinese Nationalists resumed the offensive and drove the Communists out of their sanctuary, leading to the famous 'Long March' to Shensi province in 1933. The situation in China changed drastically in 1937. Not content with the acquisition of Manchuria, Japanese hawks within the Kwantung Army engineered the 'Marco Polo bridge incident' as the pretext for invading China.

Mao's best-known works include 'Problems of Strategy in China's Revolutionary War' (1936), 'Problems of Strategy in Guerrilla War Against Japan' (1938) and 'On Protracted War' (1938), from which the following synopsis is derived:

Stage I, Strategic Defensive: This phase is characterized by avoidance at all costs of pitched, set-piece battles. Given limited resources, the adversary needs to conduct a quick military campaign and seize key cities to force a quick end to the war. One key goal of the insurgents is to get the adversary to reach what Clausewitz termed as 'the culminating point of victory': although victories and territory are won, the foe no longer has adequate forces to defend the gains made. Tactical offensives, with local numerical superiority, are carried out to further stretch enemy resources. The moral superiority of the guerrillas is established with the local population, political indoctrination is carried out and new recruits are trained to fight as irregulars in remote, safe bases.

Stage II, Stalemate: This phase begins the prolonged battle to attrit the enemy's physical and moral strength and assume de facto control over a larger segment of the population. Government control, in the form of local officials, is targeted and its representatives killed or forced to leave. The enemy is now on the defensive strategically and the insurgents will use the initiative to force the enemy from the countryside into towns and cities. With government presence in rural areas neutralized, the population can be drawn upon for moral and physical support. The focus of the guerrillas must remain unchanged and peace proposals rejected; the enemy will try and subvert opinion within the guerrilla movement.

Stage 111, Strategic Offensive: The end game of the conflict, in which the insurgents begin the battle of manoeuvre and use overwhelming force to destroy decimated enemy forces in their defensive positions.

Tse-Tung, Mao (1966), Selected Military Writings of Mao Tse-Tung (Peking: Foreign Languages Press), 210-219. 


\section{Box 1.3}

\section{Ernesto 'Che' Guevara and the Theory of the 'Foco'}

Argentinian-born Ernesto Guevara de la Serna Rosario (1928-1967) was educated as a medical doctor and plagued throughout his life by health problems including asthma. Ernesto spent much of his time after graduation travelling throughout Latin America where he gained an appreciation of the stoicism of the Latin American peasantry. He also became aware of the huge disparity between the comparable wealth of the substantial number of American companies in the region and that of the average peasant. After his political awakening he travelled to Mexico where he made the acquaintance of Fidel Castro and assisted Cuban exiles to train for revolutionary struggle. 'Che', as he is popularly known, was a member of the Granma expedition that landed in Cuba in November 1956. He served as Castro's political advisor and later as a field commander. His major work, Guerrilla Warfare, is published two years after the end of the Fidelista revolution. Che subsequently worked within the Ministry of Industries but disagreed with Castro over the direction Cuban socialism should take. The final acts in Che's life are failed attempts to foment revolution in the Congo (1965) and finally in Bolivia (1966-1967).

Che's contribution to irregular warfare theory (and articulated most effectively by Regis Debray) is the idea of foco or the centre of gravity of the guemlla movement. Practically, the foco refers to the initial critical mass of the guemllas, the vanguard of the revolution, from which all else is derived. Philosophically, the foco represents the political and military 'heart' of the insurgency and from it Guevara and Debray believe that the guerrilla movement itself can generate the conditions for a revolutionary victory (the title of a book by Debray reflects this shift: The Revolution Within The Revolution). They believe that guemlla success will eventually 'inspire' local peasants to come to support them, allowing the organisation to grow in strength. 


\section{Box 1.4}

\section{Mao's ‘Three Rules and Eight Remarks'}

\section{Rules}

1. All actions are subject to command.

2. Do not steal from the people.

3. Be neither selfish nor unjust.

\section{Remarks}

1. Replace the door when you leave the house."

2. Roll up the bedding on which you have slept.

3. Be courteous.

4. Be honest in your transactions.

5. Return what you borrow.

6. Replace what you break.

7. Do not bathe in the presence of women.

8. Do not without authority search the pocketbooks of those you arrest.

*The translator to this edition, retired US Marine Corp Brigadier General Samuel B Griffiths, notes that 'In summer, doors were frequently lifted off and used as beds.'

Tse-Tung, M. (1961), Mao Tse-Tung on Guerrilla Warfare (New York: Praeger), 92. 


\section{Box 1.5}

\section{'Hearts and Minds'}

The phrase 'the battle for hearts and minds' underscores the political dimension of irregular warfare. During the early stages of the Vietnam, or Second Indochina War (1965-1975), the South Vietnamese guerrillas, or Viet Cong, made comprehensive and coordinated efforts to win the battle by coercing peasants. Coercion took forms as divergent as public executions and village propaganda sessions. The former would sow fear among those who were thinking of supporting the government whereas repetitive proselytising played upon the predispositions of the audience, such as the desire for land reform or the need to escape the tedium of village life, in order to persuade villagers tojoin or assist the Viet Cong. The response of one particular peasant illustrates the pervasiveness and influence of politics in irregular warfare:

'In the beginning I was very hurt and angry with [the Viet Cong] for killing my father... they told me that because my father had done wrong, he had to be punished... They talked to the point where Ifelt that they were right.. .I came to hate my father even though I didn't know [exactly] what he had done.'(Italics added)

Donnell, J.C. (1967), Viet Cong Recruitment: Why and How Men Join, RM-5486-1ISA (Santa Monica, CA: Rand Corporation), 97. 


\section{Bibliography and guide to further reading}

Beam, L. (1992), 'Leaderless Resistance' [resource available on-line; see section on 'Useful Websites' below].

Clausewitz, C. (1993), On War, M.Howard and P. Paret (eds. and trans.), (London: Everyman's Library).

Clutterbuck, R. (I990), Terrorism and Guerrilla Warfare: Forecasts and Remedies (London: Routledge).

“Combatting Terrorism, Preserving Freedom". (1996), Cato Institute Online Policy Report 16(6). <http://www.cato.org/pubs/policy-report/cpr-18n6-5.html>

Debray, R. (1968), Revolution in the Revolution? (London: Pelican).

Dixon, C.A. and Heilbrunn, O.(1962), Communist Guerrilla Warfare (New York Praeger).

Donnell, J.C. (1967), Viet Cong Recruitment: Whyand How Men Join, RM-5486-1ISA (Santa Monica, CA: Rand Corporation).

Fall, B.B. (1999), 'The Theory and Practice of Insurgency and Counter-insurgency', Naval War College Review, 51(1), 46-57.

Gottman, J. (1948), 'Bugeaud, Galliéni, Lyautey: The Development of French Colonial Warfare', in E.M. Earle (ed.), Makers of Modem Strategy: Military Thought from Machiavelli to Hitler (Princeton, NJ: Princeton University Press).

Gray, C.S. (1999), Modem Strategy (Oxford: Oxford University Press).

Guevara, C. (1997), Guerrilla Warfare, third edition (Wilmington, DE: Scholarly Resources).

Hamilton, D.W. (1998), The Art of Insurgency: American Military Policy and the Failure of Strategy in Southeast Asia (Westport, CT: Praeger).

Hoffman, B. (1998), Inside Terrorism (New York: Columbia University Press).

Ignatieff, M. (1994), Blood and Belonging: Journeys into the New Nationalism (New York Farrar, Strauss and Giroux).

Jenkins, B. (1987), 'Will Terrorists Go Nuclear?' in W. Laqueur and Y. Alexander, (eds.), The Terrorism Reader: A Historical Anthology (New York: Meridian).

Joint Warfighting Center. (1995), Joint Doctrinefor Military Operations Other Than War,Joint Publication 3-07 (Fort Monroe, VA: Joint Warfighting Center). 
Katzenbach Jr., E.J., and Hanrahan, G.Z. (1962), 'The Revolutionary Strategy of Mao Tse-Tung', in F.M. Osanka (ed.), Modem Guerrilla Warfare: Fighting Communist Guerrilla Movements, 1941-1961 (New York: Free Press).

Laqueur, W. (1999), The New Terrorism: Fanaticism and the Arms of Mass Destruction (New York: Oxford University Press). This title is an expansion of the author's 1996 article 'Postmodern Terrorism', Foreign Affairs, 75(5), 24-37.

Lawrence, T.E. (1920), 'The Evolution of a Revolt', The Army Quarterly, 1(1), 55-69. The article presents a more brusque and less flowery version of the strategy of the Arab Revolt than that found in the author's popular (1935) Seven Pillars of Wisdom: A Triumph (London: Jonathon Cape), 188-196.

Marighella, C. (1969), 'Minimanual of the Urban Guemlla' [resource available online; see section on 'Useful Websites' below].

Munck, R. (2000), 'DeconstructingTerror: Insurgency, Repression and Peace', in R. Munck, and P.L. de Silva (eds.), Postmodem Insurgencies: Political Violence, Identity Formation and Peacemaking in Comparative Perspective (New York: St. Martin's Press).

Nasution, A.H. (1965), Fundamentals of Guerrilla Warfare (New York: Praeger).

Peters, R. (1994), ‘The New Warrior Class', Parameters 24(2): 16-26.

Reid-Daly, R. (1999), Pamwe Chete: The Legend of the Selous Scouts (Roodepoort, South Africa: Covos Books).

Sarkesian, S. (1988), 'The Myth of US Capability in Unconventional Conflicts', Military Review 68(9): 2-17.

Schmid, A.P., Jongman, A.J., et al (1988), Political Terrorism: A New Guide to Actors, Authors, Concepts, Data Bases, Theories, and Literature (New Brunswick, NJ: Transaction Books).

Taber, R. (1972), The War of the Flea: Guerrilla Warfare Theory and Practice (London: Paladin).

Tse-Tung, M. (1961), Mao Tse-Tung on Guerrilla Warfare (New York: Praeger).

Tse-Tung, M. (1966), Selected Military Writings of Mao Tse-Tung (Peking: Foreign Languages Press).

van Crevald, M. (1989), Technology and War: From 2000 BC to the Present (New York: Free Press).

van Crevald, M. (1991), The Transformation of War (New York: Free Press).

Wilkinson, P. (1986), Terrorism and the Liberal State (London: Macmillan). 


\section{Useful Websites}

\section{Terrorism Research Centre ४http://www.terrorism.com/index. shtml>}

This useful site has an excellent links section, including links to relevant reports and terrorism news.

This is Baader-Meinhof <http://www.baader-meinhof.com/index.htm>

This site contains excellent information on the Baader-Meinhof group specifically and terrorism in general. It has a section for students and researchers as well as links to, or the complete text of, seminal works such as Carlos Marighella's 'Minimanual of the Urban Guerrilla' <http://www.baadermeinhof.com/students/resources/print/manual.html>

\section{US State Department -- Patterns of Global TerrorismAnnual Report <http://www.state.gov/www/global/terrorism/gt_index.html>}

Archived from 1995 upwards, contains valuable information and statistics as well as American perceptions of what constitutes terrorism and the terrorist threat.

Canadian Security Intelligence Service Documents and Reports <http://www.csisscrs.gc.ca/eng/miscdocs/othere.html>

Contains several interesting reports, including the Annual Public Report and short papers on subjects such as trends in terrorism and a report assessing the WMD terrorist threat.

\section{The Vietnam WarInternet Project website}

বhttp://www.lbjlib.utexas.edu/shwv/shwohome.html>

This website, created by John Tegtmeier, contains on-line documents, articles, images and an extensive links page <http://www.lbjlib.utexas.edu/shwv/linkfaq.html\#phoenix > to military unit webpages, veteran's webpages and on-line journals.

\section{Marx to Mao Website <http://gate.cruzio.com/-marx2mao/Mao/Index.html>}

Mao's writings on guemlla warfare have been out of print for some time and this website provides the full text of most works, as well as works by Lenin, Marx and Engels.

\section{Jane's Listing of Terrorist and Insurgency Groups} <http://intelweb.janes.com/resource/Groups_table.htm>

A comprehensive table listing groups worldwide engaged in terrorism and insurgency; for more detailed information, see Jane's annual World Insurgency and Terrorism.

\section{Leaderless Resistance by Louis Beam \&ttp://www.crusader.net/texts/bt/bt04.html>}


This essay provides valuable insights into both the concept of leaderless resistance and the worldview of US militia members and 'patriots'.

Chem-Bio Website <http://www.chem-bio.com>

Numerous resources on all aspects of chemical and biological weapons, including reports from various US agencies and departments on the status of WMD antiterrorism measures.

Counterinsurgency Comics: Mr. Ba's Family and the Phoenix Operation <http://www.parascope.com/articles/0497/phoenix.htm>

Phoenix operations were the most controversial counter-insurgency actions undertaken by US forces during the Vietnam War and claims of effectiveness were overshadowed by allegations of sanctioned assassinations of member of the Viet Cong Infrastructure (VCI). This website posts a propaganda 'comic' for distribution in South Vietnam complete with English translations.

Special Operations Website <http://www.specialoperations.com>

Exhaustive number of pages devoted to all aspects of special operations, including counter-insurgency and counter-terrorism units and operations worldwide. 
Figure 1.2: Principles, Prerequisities and Laws of Counter-Insurgency and

Counter-Terrorism

(material auoted from specific texts)

\begin{tabular}{|c|c|c|c|c|c|}
\hline $\begin{array}{l}\text { Charles } \\
\text { Callwell: } \\
\text { Guiding } \\
\text { principle of } \\
\text { small wars from } \\
\text { Small Wars: } \\
\text { Their Principles } \\
\text { and Practices } \\
\text { (1899) } \\
\end{array}$ & $\begin{array}{l}\text { 'Over-awing the } \\
\text { enemy by bold } \\
\text { initiative and by } \\
\text { resolute action, } \\
\text { whether on the } \\
\text { battlefield or as } \\
\text { part of the general } \\
\text { plan of action' }\end{array}$ & & & & \\
\hline $\begin{array}{l}\text { Charles W } \\
\text { Gwynn: } \\
\text { Principles from } \\
\text { Ímperial } \\
\text { Policing (1934) }\end{array}$ & $\begin{array}{l}\text { Policy remains } \\
\text { vested in the civil } \\
\text { Government }\end{array}$ & $\begin{array}{l}\text { Minimum Use of } \\
\text { Force }\end{array}$ & $\begin{array}{l}\text { Firm and Timely } \\
\text { Action }\end{array}$ & $\begin{array}{l}\text { Co-operation } \\
\text { between civil and } \\
\text { military authorities }\end{array}$ & \\
\hline $\begin{array}{l}\text { Robert } \\
\text { Thompson: } \\
\text { Principles of } \\
\text { Counter- } \\
\text { insurgency from } \\
\text { Defeating } \\
\text { Communist } \\
\text { Insurgency } \\
\text { (1966) }\end{array}$ & Clear political aim & $\begin{array}{l}\text { The government must } \\
\text { function in } \\
\text { accordance with law }\end{array}$ & $\begin{array}{l}\text { The government must } \\
\text { have an overall plan }\end{array}$ & $\begin{array}{l}\text { The government } \\
\text { must give priority } \\
\text { to defeating the } \\
\text { political } \\
\text { subversion, not the } \\
\text { guemllas }\end{array}$ & $\begin{array}{l}\text { The government must } \\
\text { secure its base areas } \\
\text { first (in the guerrilla } \\
\text { phase) }\end{array}$ \\
\hline $\begin{array}{l}\text { David Galula: } \\
\text { Laws of } \\
\text { Counterinsurgen } \\
\text { cy from } \\
\text { Counter- } \\
\text { Insurgency } \\
\text { Warfare (1964) }\end{array}$ & $\begin{array}{l}\text { Support of the } \\
\text { Population } \\
\text { Necessary }\end{array}$ & $\begin{array}{l}\text { Support Gained } \\
\text { Through and Active } \\
\text { Minority }\end{array}$ & $\begin{array}{l}\text { Support from } \\
\text { Population is } \\
\text { Conditional }\end{array}$ & $\begin{array}{l}\text { Intensity of Efforts } \\
\text { and Vastness of } \\
\text { Means Are } \\
\text { Essential }\end{array}$ & \\
\hline $\begin{array}{l}\text { Samuel } \\
\text { Griffith: } \\
\text { summary of } \\
\text { anti-guemlla } \\
\text { operations in } \\
\text { Mao Tse-Tung } \\
\text { on Guerrilla } \\
\text { Warfare (1961) }\end{array}$ & Location & Identification & Eradication & & \\
\hline $\begin{array}{l}\text { John McCuen: } \\
\text { Counter- } \\
\text { revolutionary } \\
\text { strategy forms } \\
\text { from TheAn of } \\
\text { Counter- } \\
\text { Revolutionary } \\
\text { Warfare (1966) }\end{array}$ & $\begin{array}{l}\text { Counter- } \\
\text { organization }\end{array}$ & Counter-terrorism & $\begin{array}{l}\text { Counter-guerri Ila } \\
\text { warfare }\end{array}$ & $\begin{array}{l}\text { Counter-mobile } \\
\text { warfare }\end{array}$ & \\
\hline $\begin{array}{l}\text { Julian Paget: } \\
\text { Prerequisites for } \\
\text { Fighting the } \\
\text { Insurgents from } \\
\text { Counter- } \\
\text { Insurgency } \\
\text { Campaigning } \\
\text { (1967) }\end{array}$ & $\begin{array}{l}\text { Essentials for } \\
\text { Counter- } \\
\text { Insurgency } \\
\text { Operations: civil- } \\
\text { military } \\
\text { understanding; a } \\
\text { joint command and } \\
\text { control structure; } \\
\text { good intelligence; } \\
\text { mobility; and, } \\
\text { training }\end{array}$ & $\begin{array}{l}\text { Defeating Insurgents: } \\
\text { support of the local } \\
\text { population; bases; } \\
\text { mobility; supplies } \\
\text { and information; and, } \\
\text { the will to win }\end{array}$ & $\begin{array}{l}\text { Winning Hearts and } \\
\text { Minds }\end{array}$ & & \\
\hline $\begin{array}{l}\text { Frank Kitson: } \\
\text { Framework for } \\
\text { an effective } \\
\text { counterinsurgen } \\
\text { cy campaign } \\
\text { from Bunch of } \\
\text { Five (1977) }\end{array}$ & $\begin{array}{l}\text { Good coordinating } \\
\text { machinery } \\
\text { (between civil and } \\
\text { military agencies) }\end{array}$ & $\begin{array}{l}\text { Establishing the sort } \\
\text { of political } \\
\text { atmosphere within } \\
\text { which the } \\
\text { government measures } \\
\text { can be introduced } \\
\text { with the maximum } \\
\text { likelihood of success }\end{array}$ & $\begin{array}{l}\text { Intelligence (right } \\
\text { information = } \\
\text { sensible policy) }\end{array}$ & $\begin{array}{l}\text { Law (upholding } \\
\text { the rule of) }\end{array}$ & \\
\hline Friedrich & Preventative & Intelligence & Repressive & Constructive & \\
\hline
\end{tabular}


Figure 1.2: Principles, Prerequisities and Laws of Counter-Insurgency and

Counter-Terrorism

(material quoted from specific te xts) $_{\text {) }}$

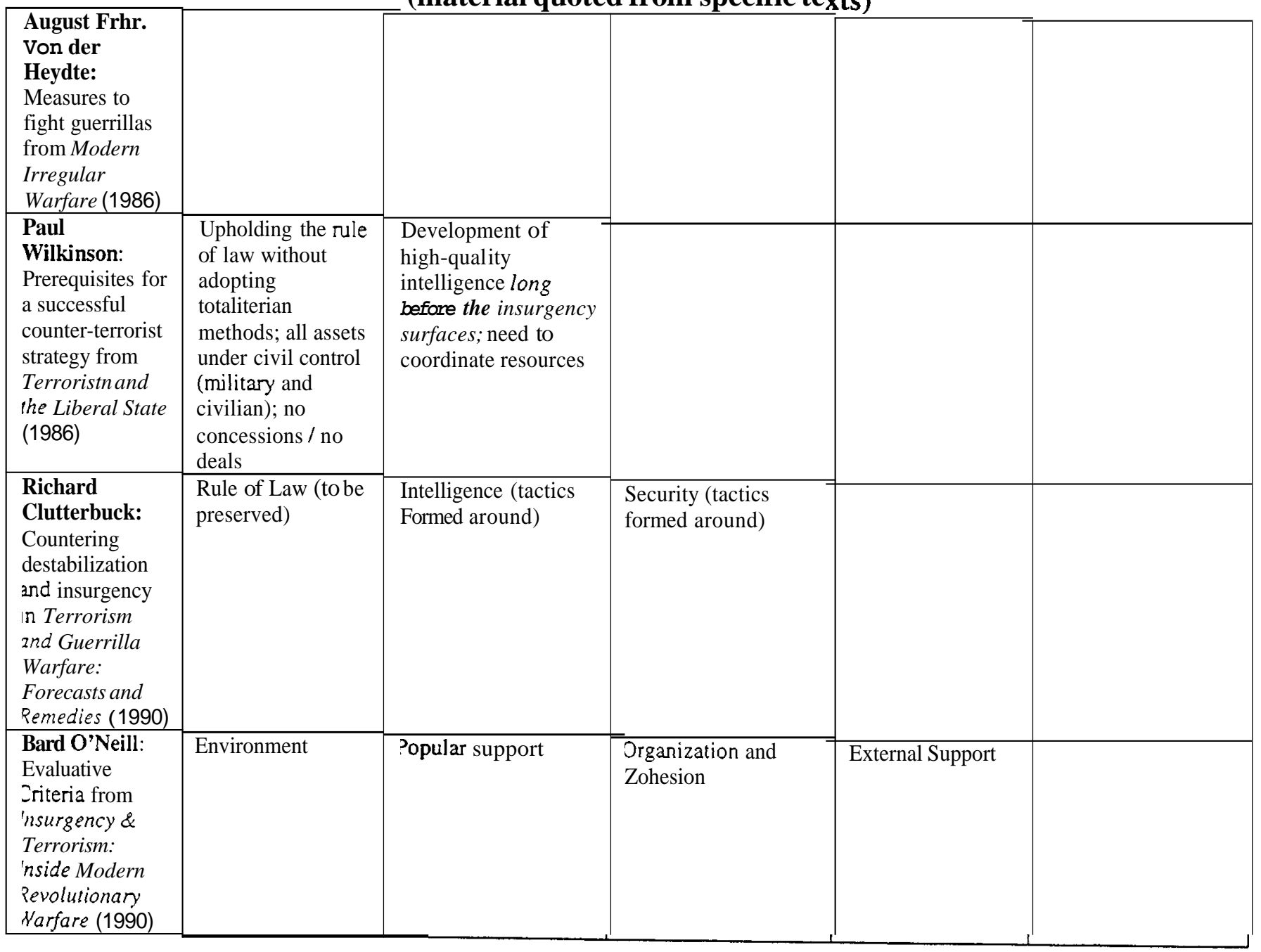




\section{Sarkesian's Conflict Spectrum - Revised}

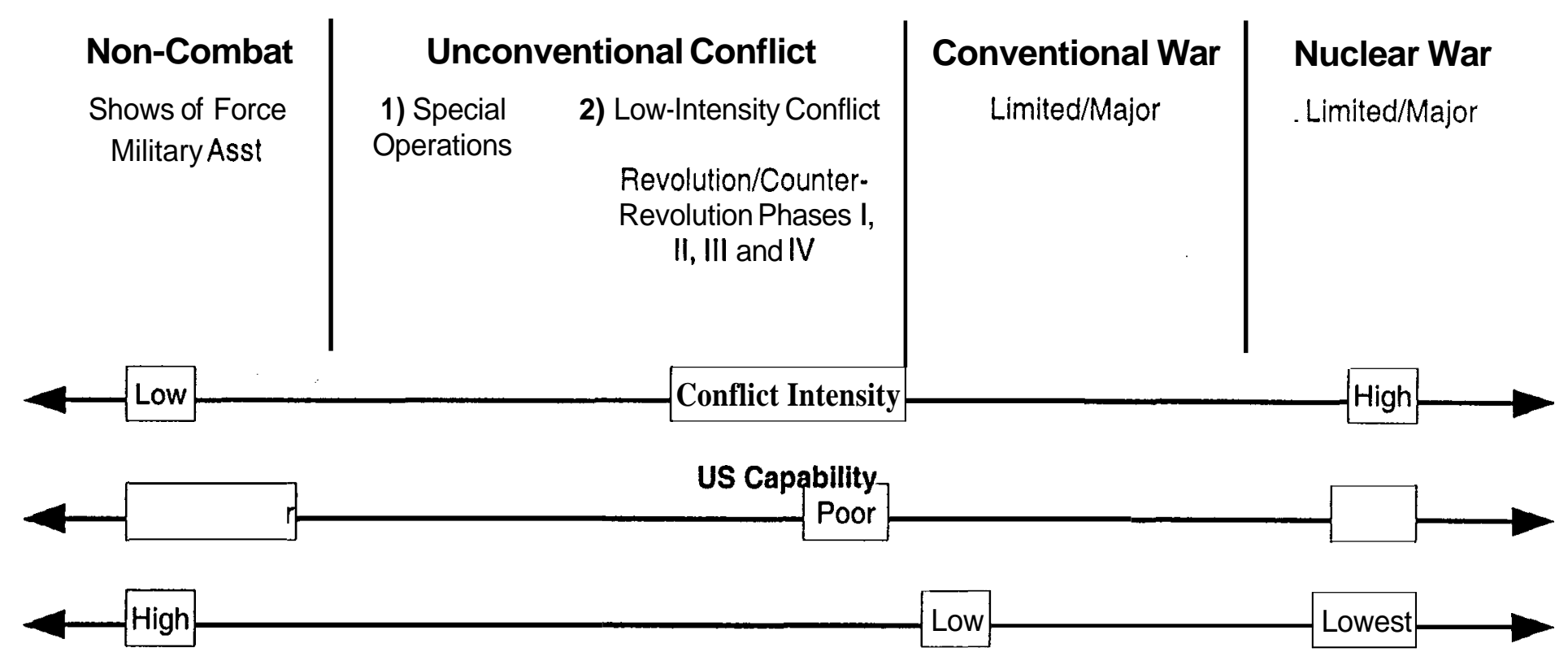

- Surgical, hit-and-run raids, counterterror, spearhead, and hostage rescue

- This conflict follows a four phase pattern of US involvement:

Phase I: Combined economic and other nonmilitary assistance and aid; weapons training teams; police training assistance; military training cadres.

Phase Il: Special Forces teams plus Phase I.

Phase III: Special Forces Headquarters (Team B and C) and additional A teams plus Phases I and II; possible first commitment of light infantry units.

Phase IV: Light infantry forces-active combat; administrative and logistical basis for expanded role plus Phase I through III, inclusive. 


\section{Humanitarian Intervention and}

\section{Peace Operations}

\section{Theo Farrell}

\section{Introduction}

Humanitarian intervention is directed towards two purposes: providing emergency assistance and protecting fundamental human rights (Minear and Weiss 1995:21). Strictly speaking, humanitarian intervention can and often does take non-military forms: emergency aid in the form of money, medicine, food and expertise, and human rights promotion through diplomacy and sanctions (Ramsbotham and Woodhouse 1996).However, usually when reporters and policymakers speak of humanitarian intervention they mean 'forcible military intervention in humanitarian crises.' Such intervention is necessary in failed states, when ongoing conflict threatens aid operations, and against murderous states, to stop massive human rights abuses (Wheeler 1997).

Humanitarian intervention is a post-Cold War activity. During the Cold War, it was rare for three reasons.' First, the Cold War dominated international politics. Great powers focused their military efforts on waging the Cold War, building up massive deterrent forces for this purpose. The great powers did intervene in Third World conflicts, but this was for the purpose of supporting ones' own, or undermining the other sides', client states. Such military intervention served to fuel these proxy wars rather than stop them. The great powers also funded and armed client states engaged in massive human rights atrocities. Second, there was insufficient public

\footnotetext{
1 The two main humanitarian interventions that did occur during the Cold War were unilateral military interventions by one Third World state against another: Tanzania's 1978 intervention in Uganda, and Vietnam's 1979 intervention in Cambodia. In both cases, intervention was justified on grounds of self-
} 
pressure for the great powers to do anything to ameliorate Third World conflicts. Publics in East and West were indoctrinated into viewing these conflicts and client states as elements of a larger Cold War battle, in which human rights could be sacrificed in the interests of national security. Third, Cold War politics prevented international collaboration in suppressing Third World conflicts or punishing murderous states, chiefly by paralysing the UN Security Council (UNSC). To be legal, forcible military intervention in a humanitarian crises must be authorised by a resolution of the Security Council. However, UNSC resolutions can be vetoed by any one of the permanent five members (P5). With the P5 split along the Cold War divide Britain, France, the United States versus the Soviet Union and latter China each side traded vetoes: 279 in all during the Cold War (Boutros-Ghali 1992: para. 14).

The last decade of the twentieth century saw an unprecedented increase in the number and scale of military interventions by United Nations forces: this has been called the new interventionism (Mayall 1996). Between 1998 and 1993alone, 20 new peacekeeping missions were established. At the same time, the size of the annual UN peacekeeping budget which shot up from $\$ 230$ million in 1988 , to between $\$ 800$ million and $\$ 1.6$ billion throughout the 1990s. Behind this increased activity was the end of the Cold War, which produced the demand, opportunities and incentives for UN sponsored humanitarian intervention. A series of regional peace agreements in Afghanistan, Angola, Namibia, Central America and Cambodia accompanied the winding down of the Cold War, and these demanded peacekeeping forces to supervise cease-fires, military demobilisation, and elections. The opportunities to do something about this existed with increased great power co-operation in the UNSC and with the freeing up of surplus Cold War military capability for peacekeeping duties. Incentives for humanitarian intervention have come from public pressure on Western governments to do something about large-scale civilian suffering in failed and murderous states.

YET TO INSERT: Discussion (1)locating chapter in subject of strategic studies; (2) setting out aims of chapter; and (3) providing roadmap of chapter. 


\section{From Traditional to Wider Peacekeeping}

A few military deployments of limited size and scope were authorised by the UNSC during the Cold War in the context of traditional peacekeeping. Commonly referred to as 'Chapter VI and a half' activity, traditional peacekeeping is seen to lie somewhere between Chapter VI of the UN Charter on 'Pacific Settlement of Disputes' and Chapter VII which provides for use of force by the United Nations to uphold international peace and security. Traditional peacekeeping missions were deployed only when a conflict had ceased and with the consent of the belligerents. They typically served to monitor cease-fires and supervise truces; occasionally, peacekeeping missions were deployed to keep belligerents apart as in Cyprus in 1974. These missions relied on their impartiality and the goodwill of the parties concerned to fulfil their mandate. Accordingly, they were small in size and lightly armed, typically comprising contingents from neutral and non-aligned states. Between 1948and 1978, 13 such missions were established, with none for the decade thereafter (Roberts 1994:93-5). Only once during the Cold War did the United Nations authorise a US led peace enforcement mission under Chapter VII; in 1950against North Korea? On another occasion, the UNSC permitted the peacekeeping mission in the Congo (1960-64) to turn into a peace enforcement operation to restore public order and protect.the government.

In contrast, the UN humanitarian interventions of the post-Cold War era have been much larger, more complex affairs than predecessor missions. These new interventions have involved a much wider range of tasks, including protecting territory, people, and aid operations, disarming belligerents, policing demilitarised sites, and monitoring demobilisation, monitoring and running elections, and helping to reconstruct governments, police forces, and armies. The British Army initially called these operations wider peacekeeping. This term not only reflected the wider range of operational tasks involved. It also recognised that such peacekeeping operations occupied a grey area between traditional peacekeeping and peace 
enforcement.Not all aspects of these mutli-task missions had the full consent of all the parties on the ground. Whereas consent was central to traditional peacekeeping, it was not to the new breed of wider peacekeeping. Peacekeepers had to be able to threaten and to use force to achieve their mandate; if necessary, to force aid through to the starving, to repulse attacks on civilians, to forcibly disarm troublemakers, and to arrest war criminals.

In fact, the British Army's interim doctrine on Wider Peacekeeping (1994) was designed to caution policymakers and the public about the costs of using force in peacekeeping (unusually for military doctrine, a glossy version was on sale at bookstores). Critical here is the relationshipbetween consent, force, and impartiality. Wider Peacekeeping distinguished between the tactical and operational level of consent for peacekeeping missions. It argued that should consent be withdraw at the tactical level, where one or more belligerent groups obstruct peacekeepers in the field, small amounts of force may be used to keep the mission on track. However, it warned that excessive use of force could result in a collapse of consent for the mission as a whole (i.e., at the operational level). Under such circumstances, the mission would have crossed the 'consent divide', undermining its credibility as an impartial peacekeeping force and prejudicing mission legitimacy in the eyes of the belligerents. Loss of control and uncontrolled escalation in violence (includingattacks on peacekeepers) were bound to follow

\section{FIGURE 1 HERE}

Wider Peacekeeping deliberately painted a bleak picture of what happens when a modest force is given an ambitious mandate. It came at a time when the British Army was being asked to do much in Bosnia with few resources on the ground. This doctrine also reflected the UN operation in Somalia, which took on one of the warring factions and lost (see next section). It certainly resonated with the first British commander of UNPROFOR, General Sir Michael Rose, who referred to the consent divide as the 'Mogadishu Line'. The lesson was clear to General Rose: 'In Somalia, it has been well demonstrated that it was the move by the UN Force from peacekeeping to 
war-fighting which so terminally damaged the prospects of the Mission' (Rose 1996: 151).However, this attitude, reflected in WiderPeacekeeping, was unhelpful when peacekeeping missions had no choice but to the consent divide into peace enforcement. Wider Peacekeeping rightly warned that this must be a deliberate act of policy, but gave little advice as to what should happen next. This was because the chief author of Wider Peacekeeping, Colonel Charles Dobbie (like General Rose), considered peace enforcement to be synonymous with war, and thus not the business of peacekeepers (see Box 1).

\section{BOX 1 HERE}

However, Dobbie's approach is too passive for it leaves peacekeepers dependent on the co-operation of the warring parties. Under such circumstances, peacekeeping missions can fall prey to 'spoilers - leaders and parties who believe that believe that peace emerging from negotiations threatens their power, worldview, and interests, and use violence to undermine attempts to achieve it' (Stedman 1997:5). Where spoilers are identified, peacekeepers must be able to engage in robust and aggressive action to bring them to heal. This option was discouraged by the sharp distinction between peacekeeping and peace-enforcement draw in Wider Peacekeeping. In contrast, the US Army grouped peacekeeping and peace enforcement under the category of peace operations. In its doctrine, Peace Operations (1994), many of the tasks originally viewed as wider peacekeeping by the British, are conceived as peace enforcement by the Americans. These tasks invariably involve coercing belligerents to comply with UNSC resolutions: in short, to use force to induce consent for peace operations (Jablonsky and McCallum 1999).Peace Operations advises US commanders as to how combat power can be used to induce consent. The British Army have since moved to closer to this position. It accepts that it must prepare to use forcein peace operations, and that impartiality ought to be defined not in relation to the warring parties but to the mission mandate: i.e., force will be used equally against all who threaten the mission (Thorton, nd).

The importance of being prepared to neutralise peace spoilers and thereby induce consent is well illustrated in the UN intervention in Bosnia (seeBox 2). From 1992 to 1995, a 7,000 strong force deployed in Bosnia as part 
of the United Nations Operations in Former Yugoslavia (UNPROFOR) attempted to alleviate the sufferingof civilians trapped in the midst of a war, waged by Serbia and Croatia (in collusion with their Serb and Croat allies in Bosnia) against the new-born multi-ethnic and democratic Bosnia state. Under General Rose and with the support of the UN Secretariat in New York, UNPROFOR defined its principal mission as helping to deliver aid (Rose 1996: 152).Later, it was mandated by the UNSC to watch over six designated 'safe areas' in Bosnia. These were enclaves of Muslim civilians surrounded by the Bosnian Serb military. Under Rose, UNPROFOR was not prepared to use force to push aid through road blockades or to protect civilians (including those in so-called 'safe areas'). During this time, UN policy amounted to a policy of 'endless appeasement' (Thompson 2000); it relied on the goodwill of Bosnia Serb extremists to let aid through, protect defenceless Muslim civilians, and negotiate a peace. Yet these same Bosnian Serbs were bent on destroying multi-ethnic Bosnian democracy through a campaign of murder and terror against the Muslim population. Certainly, there was a dilemma facing UNPROFOR calling in air-strikes to punish Serb transgression would push it across the consent divide, but it lacked the land power to defend aid convoys and safe areas against Serb retaliation. But UNPROFOR's military weakness was reinforced by a weakness in UN thinking which ruled out a military solution to the Bosnian crisis. For even when UNPROFOR was reinforced by a Anglo-French Rapid Reaction Force of helicopter gunships and artillery, the UN Secretariat was reluctant to get tough with Bosnian Serbs. Thus, even when it was militarily equipped to deal with Serb Spoilers, it was conceptually ill-equipped with do so. The final straw was the overrunning of two safe areas, Srebrenica and Zepa, and slaughtering of the male civilian inhabitants by Bosnian Serb forces. Rose's replacement, British General Rupert Smith, decided that it was time to 'escalate to success.' In retaliation for Serbian shelling of Sarajevo (another'safe area') in August 1995, he called in NATO airstrikes. This military pressure in combination with military advances by Bosnian government and Bosnia Croat forces in the Eastern Bosnia persuaded the Bosnian Serbs to sue for peace. 


\section{Intervention Failures}

The consent divide-induce consent debate may be recast in more general terms as a clash of two perspectives: intervention pessimism versus intervention optimism Basically, intervention pessimism is the belief that little can be done about humanitarian disasters without the consent and cooperation of the major parties concerned (Tharoor 1995-96); all is lost if the peacekeeping force crosses the consent divide. Intervention optimism is the belief that the international community can forcibly rebuild failed states and reform murderous ones (Minear and Weiss 1995); operational success depends on the ability to induce consent if required. This tension between these opposing perspectives was played out in the cases of the two greatest failures in post-Cold War humanitarian intervention:Somalia and Rwanda. Intervention optimism led the United Nations to launch a recklessly ambitious operation aimed at disarming Somalia and reconstructing the government. Intervention pessimism led the United Nations to do nothing about to stop genocide in Rwanda. As we shall see, the UN should have done less in Somalia, and could have done much more in Rwanda.

Somalia (1992-1995)

The crisis in Somalia was generated by a combination of civil war and famine. The country descended into a second civil war in mid 1991, which was directly responsible for the deaths of tens of thousands of civilians. Much worse, was the deadly famine that gripped Somalia in 1992. War and general lawlessness was making it extremely dangerous and difficult for Western aid agencies to operation in Somalia. The deployment of force of 550 Pakistani peacekeepers in mid 1992, the United Nations Operations in Somalia (UNOSOMI), did little to improve things. UNOSOM I operated with the consent of the main warlords in Somalia. However, since aid was power, the warlords were unprepared to let it flow freely. 
Under intense pressure from UN Secretary General Boutros BoutrosGhali, and US based aid agencies, the United States led a 37,000 strong United Task Force (UNITAF)into Somalia (including28,000 US troops) in early December 1992.Under UNSC Resolution 794, UNITAF was mandated to 'use all necessary means to establish as soon as possible a secure environment for humanitarian relief operations in Somalia.' UNITAF achieved this setting itself the modest goal for creating demilitarised zones around aid operations (as opposed to the more ambitious goal of disarming the warring factions) by then by using overwhelming military superiority to scare off armed groups from its area of operations. By its own measure, UNITAF was a success; aid got to the starving, and the famine receded.

UNITAF handed over to a new 28,000 strong UN force, UNOSOM II, in mid 1993.UNOSOM II had a more much ambitious mandate; nothing less than the forcible disarmament of the warring factions and assisting in the reconstruction of the Somali state (UNSC Res. 814). Boutros-Ghali had wanted to see a general disarmament in order to produce lasting security in Somalia. The new Clinton Administration which came into power full of optimism about the multinational peacekeeping, was receptive to broadening the UN's role in Somalia. However, the new mandated placed the United Nations on a collision course with the Somali warlords. In June 1993, one Somali faction ambushed a UN patrol, killing 24 Pakistani soldiers. The UN responded by effectively declaring war on the warlord responsible, General Aideed: UNOSOM II was mandated to 'take all necessary measures against all those responsible for the attacks' (UNSCRes. 837). It was a war the UN was to lose. UNOSOM II spent the Summer in pitched battles with Somali gunmen, while an elite US Quick Reaction Force ( $Q R F)$ buzzed around the Somalia capital in helicopters, Mogadishu, hunting for Aideed. Any goodwill on the part of the general Somali populace towards the UN melted away as US helicopter gunships blew up buildings. The mission ended in disaster, when the QRF was ambushed on October 3 during a mission intended to capture top Aideed officials. US helicopters were shot out of the sky, and in the intense fire-fight that followed 18US soldiers were killed, 78 were injured, and one was captured. That effectivelyended the American involvement in Somalia; within months, US forces had pulled out. UNOSOMII dragged on until 1995, but without much UN heart and US backing, it achieved little. 
Somalia was the 'Vietnam' of peacekeeping. Despite pouring money (\$1.6billion), material and personnel in Somalia, the United Nations failed restore long-term order and rebuild the state. UNOSOM II tried to do too much with too little: it lacked the command capabilities and combat power of UNITAF, yet it was tasked to do something UNITAF had deliberately avoided: disarming the warlords. In the wake of the dramatic collapse of UNOSOM 11, the modest achievements of UNITAF were forgotten.

Rwanda (1993-94)

Over about 100 days, between April and July 1994, 800,000 people was massacred in Rwanda. This humanitarian crisis was caused by a power struggle between Hutu extremists and Hutu and Tutsi moderates, which broke out when the Hutu dominated regime of President Habyarimana bowed in the early 1990s to domestic and international pressure for the introduction of multi-party democracy. The regime sought to increase its base of support by bringing extremist Hutu opposition parties into a transitional government. This occurred in the context of simultaneous military and economic pressure on the government, respectively brought by invasion from neighbouring Uganda by the Tutsi army of Rwandese Patriotic Front (RPF), and a dramatic fall in export revenues combined with severe drought. Once in government, $\mathrm{Hu}$ b extremists used their monopoly of mass media to incite attacks against Tutsis and moderate Hutus, and to organise militias to carry out small-scale massacres. In reprisal, the RPF army launched an attack on the capital Kigali in 1993, that was only repulsed with French military support. After such a close call, Habyarimana was forced to sign a peace deal with the RPF that led to Tutsi inclusion in the government and the exclusion of Hutu extremists. This was the trigger for genocide in Rwanda. In order to retain power and avoid judicial accountability for complicity in attacks on Tutsi civilians, Hutu extremists got rid of the President (shooting down his plane on April 6th) and began out a systematic campaign of mass slaughter designed to eliminate all opponents and incriminate the entire Hutu population in the process. 
There was a UN peacekeeping force on the ground when the genocide started in early April; the 2,500 strong United Nations Assistance Mission for Rwanda (UNAMIR).UNAMIR had been deployed with a very limited mandate (UNSC Res. 872) to monitor the cease-fire between the government and RPF, and to assist in relief operations. Under-staffed, under-resourced, and unauthorised to use force to prevent war crimes, UNAMIR was completely overwhelmed by the horror that unfolded around it. Amidst the massacres, force of French, Belgian, and Italian troops arrived to evacuate Europeans but did not stay to save Rwandese. To make matters worse, the Belgian and Bangladeshi contingents of UNAMIR were withdrawn by their national governments (in Belgian's case, after 10Belgian soldiers were brutally murdered by Hutu extremists). The RPF retaliated by resuming its offensive against the Hutu authorities. The United Nations responded in April 21st, by reducing UNAMIR down to 270 personnel, and focusing its effects on re-establishing the cease-fire. It was not until May 17th that the UNSC adopted Resolution 918, expanding UNAMIR to 5,500 and authorising it to protect the populace. However, UN member states were not forthcoming with these forces and, one month later, UNAMIR was still only 500 strong. Eventually, the genocide ran out of steam. The RPF managed to save some civilians by sweeping Westwards across the country and pushing back Hutu extremists. In July 9th, the French deployed a force of 2,300 troops ostensibly to create a Humanitarian Protection Zone in the Western comer of Rwanda, but in reality to protect their retreating Hutu allies who eventually fled across the border to (what was then) Zaire.

The current UN Secretary General, Kofi Annan, has acknowledged the UN's failure in Rwanda. It has been widely argued that the United Nations could have stopped the genocide in its tracks by rapidly deploying a small force of even 5,000. This argument has recently been disputed by Alan Juperman. Juperman's counter-argument, which focuses on the option of a US military intervention, runs as follows. The earliest time that President Clinton could have been aware of the scale of the massacres was two weeks have the genocide started, April 20th: by this time, 250,000 people had already been slaughtered. The smallest conceivableUS military deployment, a 2,500 strong Air Assault Brigade, would riot have arrived before fourteen days: too late to save more than 75,000 people. For, as Human Rights Watch acknowledged, 
'the worst massacres had finished by the end of April' (Juperman2000). However, Juperman downplays the option of beefing-up UNAMIR prior to the genocide. He disputes the argument that the UN had 'three-months' advance notice of genocide.' Here he is referring to a cable from the UNAMIR Force Commander, Major-General Roméo Dallaire, which reported high-level intelligence predicting the genocide as it actually unfolded. Juperman notes that Dallaire had doubts about the reliability of his informant (whohappened to be Prime Minister Designate) and that '[r]aising further doubt, the cable was the first and last from Dallaire containing such accusations' (Juperman 2000: 113 [emphasisadded]).Juperman fails to note that Dallaire's political advisor reported to Kofi Annan, then Under-Secretary General for Peacekeeping, his 'total, repeat total, confidencein the veracity and true ambitions of the informant.' (UN 1999b: 6). Furthermore, Dallaire's command warned on the 2nd, 15th, and 23rd February of the worsening security situation. The United Nations could have done a lot more to halt the genocide. That is the finding of the Independent Inquiry set up by General Secretary Annan to investigate the UN response to the Rwanda crisis. The Inquiry found 'an overriding failure [by the United Nations] to create a force with the capacity, resources and mandate to deal with the growing violence and eventual genocide in Rwanda“ (UN1999b: 19).Its conclusion is inescapable: 'The Security Council bears a responsibility for its lack of political will to do more to stop the killing' (UN 1999b: 23).

\section{The Shadow of Somalia}

Somalia is partly to blame for the failure of the UN intervention in Rwanda. It explains why Secretary General Boutros-Ghali and President Clinton started out intervention optimists but ended up intervention pessimists. The Secretary General's first Agenda for Peace, published in 1992, was decidedly upbeat about the prospects for wider peacekeeping and calling on member states to provide more resources for such operations. Significantly, it defined peacekeeping as 'the deployment of a United Nations presence in the field, hitherto with the consent of all the parties concerned' (1992: uara. 20 Jemphasis 
added]). Similarly, President Clinton entered office in 1993seeking to expand America's commitment to multilateral peace operations. This was reflected in drafts of Presidential Decision Directive 25 (PDD-25), The Clinton Administration's Policy on Reforming Multilateral Peace Operations. After disaster in Somalia, Boutros-Ghali and Clinton both changed tune. Boutros-Ghali's 1995 Supplement to an Agenda for Peace re-asserts the crucial importance of consent, impartiality, and non-use of force to operational success (UN 1995: para. 33). Equally, the final version of PDD-25 released in May 1994 stated that 'it is not US policy to seek to expand either the number of UN peace operations or US involvement in such operations' (cited in Daadler 1996:482). The lack of political will identified by the Independent Inquiry on the UN Response to Rwanda, was all too evident in Boutros-Ghali's failure to push the case for intervention, matched by US (and UK) obstruction in the Security Council of a rapid UN response.

\section{The Politics of Humanitarian Intervention}

Politics gives meaning to humanitarian crises, defining those that demand international response. It selectively focuses international attention on human suffering and human rights abuses on certain places in space and time. Serbia's brutal repression of Kosovo triggered Western humanitarian intervention; Russia's brutal repression of Chechnya did not. Equally Iraqi attacks on Kurds in 1991 resulted in the creation of a Kurdish 'SafeHaven' in Iraq guarded by thousands of troops and Allied airpower, while even more murderous Iraqi attacks on Kurds five years earlier [check year] met with no international response. Politics also shapes the form of humanitarian intervention: the speed and scale of international response. Politics operates at two levels, in particular, to define crises and shape responses: at the level of domestic public opinion, and the level of Security Council politics.

\section{Public Opinion}


It is commonly believed by policymakers and commentators alike that Western public opinion can make and break humanitarian interventions. Public opinion can prompt military intervention when the public responds to media images of massive suffering. Thus, 'extensivemedia coverage of emaciated Somalis ensured a suitable international outcry (the 'Do Something' response)' (von Hippel 2000: 59) and later in Bosnia, according to the US Special Envoy Richard Holbrooke, 'the reason the West finally, belatedly intervened was heavily related to media coverage' (cited in Robinson nd: 12). This is called 'the CNN effect': coined after the Cable News Network's total televised coverage of the Gulf War. At the same time, public support for humanitarian interventions are assumed to be conditional on minimal peacekeeper casualties. This is 'the bodybags effect'; referring to the impact of returning bodybags with American war dead on US public support for the Vietnam War. We may expect the public to be particularly sensitive to casualties in humanitarian interventions because these military actions are freely entered into by their government: in this sense, they are 'wars of choice', as opposed to 'wars of necessity' that must be fought to preserve national security (Freedman 1998-99).It is also widely believe that the bodybags effect is heightened in the televised age, in that extensive media coverage of dead peacekeepers will lead to a collapse of public support for a mission. In this sense, it is argued that the CNN effect is a 'double-edged' sword; the off-cited example is Somalia: that is, the collapse in US support following the deaths of 18 American soldiers (see Box 3 ).

As a concept, 'the CNN effect' is quite misleading. It underestimates the extent to which governments can frame the media debate, and thereby choose the place and moment of intervention (Robinson 1999). Generally, governments will be least able to do this when they are uncertain as to the best policy to pursue (whether to intervene or not, and how), and when those lobbying for intervention are able to mobilise opposition politicians behind their cause. Disunity within the politician establishment, be it within the executive or across the executive-legislative divide, not only reduces the executive's ability to influence the media debate it also makes the public more responsible to media calls for intervention. In the case of Somalia, the CNN effect did operate because the Bush Administration was uncertain as what to do, and there was a powerful pro-intervention coalition comprised of US aid 
agencies and sympathetic members of Congress (Strobe1 1996).However, in the case of Kosovo in 1999, the Clinton administration was able to resist media pressure for a US led ground forceintervention to stop Serbian atrocities against ethnic Albanian Kosovars; the administration was certain that it did not want to adopt such a policy, and opposition politicians in Congress were also against a ground intervention (Robinsonnd).

'The bodybags effect' is similarly misleading. Empirical evidence from opinion polling suggests that peacekeeper casualties do not necessarily result in public calls for an immediate withdrawal. In the case of Somalia, most Americans favoured increased US military involvement following the killing of US soldiers. The polls also show that American public support was primarily conditional on evidence of Somali public support for US involvement in the UN mission, and much less so on US casualties. If ordinary Somalis wanted US troops to go home, then ordinary Americans saw little reason to for their soldiers to stick around. But if Somalis appreciated what US forces were doing on their behalf, then most Americans were prepared to support the intervention even if there were US fatalities. America pulled out of UNOSOM II following the deaths of its soldiers because of an anticipated (rather than actual) collapse of US public support. US policymakers expected that their public would demand an immediate US withdrawal and acted to head off this public reaction (Kull and Destler 1999: 106-8). What the Somali case does reveal is the importance of domestic political unity in sustaining public support interventions. Doubts were expressed in Congress about US involvement in Somali in the Summer 1993 when UNOSOM II drifted into war against Aideed, and this resulted in a drop in public support for the mission; public support actually rallied in the short term following US casualties (Burk 1999).

Rather than focusing on public sensitivity to casualties it might be more analytically useful to think in terms of political sensitivity to casualties. Governments will be sensitive to casualties when there is policy uncertainty and political disunity which, in turn, will have already eroded public support for missions. There is also reason to believe that political sensitivity may vary greatly from country to country. Just as the loss of 18US soldiers ended America's involvementin Somalia so the deaths of 10Belgian troops caused Belgian to pulled out of Rwanda. However, Pakistan did not withdraw its 
contingent from UNOSOM II when it lost 24 soldiers, nor was Britain's commitment to its intervention in Sierra Leone in 2000 shaken by battlecasualties. This may have something to do with the political structure of countries, with some more likely to encourage and enable political disunity (e.g., sharing of powers and executive-legislative divide in the United States) than others (e.g., executive dominance of Parliament in Britain). Obviously, political sensitivity has operational implications, which are discussed in section X.

\section{Security Council Politics}

The fifteen members of the Security Council have the responsibility for authorising humanitarian interventions. A majority of nine UNSC members are needed to take such a decision. However, real power resides with the P5, and their individual right of veto. As we saw, conflict between the P5 during the Cold War made the UNSC moribund as an instrument for managing international security. With the Cold War over, co-operation between the P5 has greatly improved. But fourpolitical problems still dog UNSC sponsorship of humanitarian interventions.

Even after the Cold War, the P5 remain states great power interests and aspirations. Where a particular humanitarian crisis is association with a certain P5 member (or members), others may withhold their support or even threaten to veto unless support is promised in exchanged for their interests elsewhere in the world. This is log-rolling problem. Thus, Russia and later China in obstructed UNSC Resolutions on peace operations in Haiti. Russia wanted UN endorsement of its own intervention in Georgia in 1994, while China was seeking a public apology from Haiti for inviting Taiwan's VicePresident to the inauguration of Haiti's new President in 1996(Malone 1997 138-9).Sometimes, great power differencescan produce a veto problem, when one P5 refuses to contemplate a LJNntervention which it considers threatening to its interests and/or aspirations. This was evident in Russia's approach to Kosovo in the late 1990s: Russia refused to recognise the humanitarian dimensions of the evolving crisis and was clearly prepared to veto a UN intervention (Levitin 2000). This veto problem was solved bv 
independent action by the North Atlantic Treaty Organisation (NATO); an action which was to have significant implications for international law (see section $\mathrm{X}$ ).

Even when the P5 all agree to authorise the deployment of a UN peace operations force, two problems can still hinder effective UN intervention. The first is the P5 tendency to 'talk the talk' but not 'walk the walk.' The great powers acting through the UNSC often pass grand sounding Resolutions which they fail to back up with force. This is the posturing problem. The creation of 'safe areas' in Bosnia is a classic example; these areas were not at all safe, because the UNSC was not prepared to deploy additional military forces to actually protect them (see Figure 2). In this case, several UNSC members as well as the UN Secretariat warned at the time that 'without the provision of any credible military threat' these safe areas were meaningless (UN 1999a: 110). But the great powers went ahead regardless and set up defenceless 'safe areas'.

\section{FIGURE 2 HERE}

Finally, even when some of the P5 are prepared to 'walk the walk', they may totally disagree on which direction to take. Great powers may disagree on the nature of the humanitarian crisis as well as the most effective response. This is the co-ordination problem, which again was evident in Bosnia. The United States and its European allies had completely different perceptions of the Bosnia conflict which led them to fundamentally disagree on the appropriate response. The European powers saw an ethnic conflict, the solution to which was some form of partition. However, the United States saw it as a war started by Serbia and consequently were unprepared to support partition because this would reward Serbian aggression.It was only when this co-ordination problem was resolved in 1995, by the United States accepting that partition was a necessary evil, that the international community were able to take effective action to end the Bosnian war (Glitman 1996-97). Militarily speaking, all these political problems have adverse operational implications. It is to this that we now turn. 


\section{The Military Character of Peace Operations}

BASIC ARGUMENT: Peace operations breach many of the principles of war; many of these operational pathologies flow from the politics of humanitarian intervention.

\section{KEY CONCEPTS}

Unclear purpose, disunity of command, means-ends gap, dispersal of force Strategic compression of the battlefield: tactical actions have strategic consequences.

Also need to manage the media battle.

Over-reliance on airpower

Sacrificing the mission to force protection

The perverse effects of exit strategies

\section{Intervention Norms and International Law}

BASIC ARGUMENT: brief description of relevant international law and evolution of intervention norms; go on to argue that recent humanitarian interventions suggest internationalnorms exceeding the current state of international law.

KEY CASES:

Evolution of international norms: Kurdistan, Somalia, Cambodia, Haiti. Norms outstripping law: Kosovo

\section{Conclusion: Problems and Prospects}

Reforming the United Nations

Regionalism and Great Power Intervention 
INCOMPLETE DRAFT (15 September 2000)

Democracy, Development and Stable Security 


\section{Box 1. Charles Dobbie on Peacekeeper and Peace Enforcers as Pigs and Parrots}

'[P]eacekeeping and peace-enforcement cannot be guided by a set of common principles. The peacekeeper to peace-enforcer is as referee to football player. The objectives of each are different. One is there to win, the other to ensure fair play ....Like pigs and parrots, the differences between peacekeepers and peace-enforcers outweigh their similarities...Peacekeeping is depicted as a scaled-downversion of peaceenforcement [in US military thinking]. The pig, in effect, is being regarded as small species of parrot.....[This] can lead to peackeeping being subject to a set of common principles that impose combatant, adversary-orientated attitudes on the impartial third-party activities that constitute peacekeeping. Pigs are, as it were, being encouraged to fly.'

(Dobbie 1994: 141-2) 


\section{Box 2. The UN's Failure to Stop Serb Spoilers in Bosnia}

'With the benefit of hindsight, one can see that many of the errors the United Nations made [in Bosnia] flowed from a single and no doubt wellintentioned effort: we tried to keep the peace and apply the rules of peacekeeping when there was no peace to keep. Knowing that any other course of action would jeopardize the lives of the troops, we tried to create - or imagine- an environment in which the tenets of peacekeeping - agreement between the parties, deployment by consent, and impartiality - could be upheld...None of the conditions for the deployment of peacekeepers had been met: there was no peace agreement - not even a functioning ceasefire - there was no clear will to peace and there was no clear consent by the belligerents....Nor was the provision of humanitarian aid a sufficient response to "ethnic cleansing" and to an attempted genocide....The Bosnia Malim civilian population thus become the principal victim of brutally aggressive military and paramilitary Serb operations to depopulate coveted territories in order to allow them to be repopulated by Serbs... In the end, these Bosnian Serb war aims were ultimately repulsed on the battlefield, and not at the negotiating table. Yet the [UN] Secretariathad convinced itself early on that broader use of forceby the international community was beyond our mandate and anyway undesirable. In a report to the Security Council, the Secretary-General[Boutros Boutros-Ghali] spoke against a "culture of death", arguing that peace should be pursued only through non-military methods. When, in June 1995, the international community provided UNPROFOR with a heavily armed rapid reaction force, we argued against using it robustly to implement our mandate. We decisive action was finally taken by UNPROFOR in August and September 1995, it helped to bring the war to a conclusion.'

(Kofi Annan 1999) 


\section{Box 3. The CNN Effect as a Double-Edged Sword}

'The fact that the US pulled the plug on its Somali intervention after the loss of eighteen US Rangers in a fire-fight in October 1993indicates how capricious public opinion is. Televised images of starving and dying Somalis had persuaded the out-going Bush administration to launch a humanitarian rescue mission, but once the US public saw the consequences of this in terms of dead American being dragged through the streets of Mogadishu, the Clinton administration was forced to announced a timetable for the withdrawal of all US forces from Somalia. What this case demonstrates is that the "CNN factor" is a double-edged sword: it can presurize governments into humanitarian intervention, yet with equal rapidity, pictures of casualties arriving home can lead to public dillusionment and calls for withdrawal.' 
A New Agenda for Security \& Strategy?

\author{
James J. Wirtz
}

\author{
STRATEGY IN THE \\ CONTEMPORARY WORLD \\ Naval Postgraduate School \\ 19-21September 2000
}




\section{A New Agenda?}

- The Most Important Topic!

- The Litany of Concerns

- Remember the Limits of Growth?

- The Normative Bias

- The Strategic Effect

- Preliminary Observations 

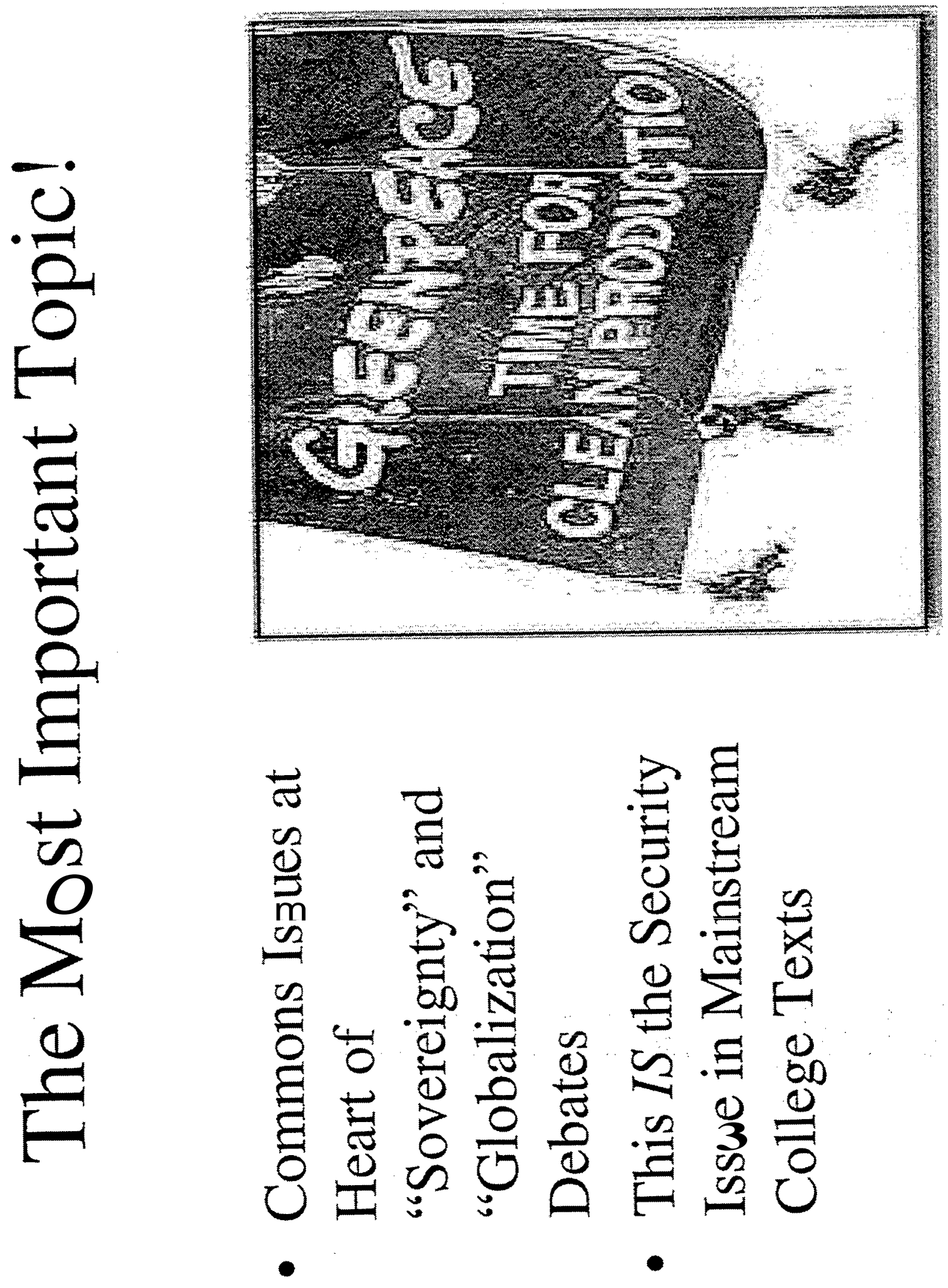

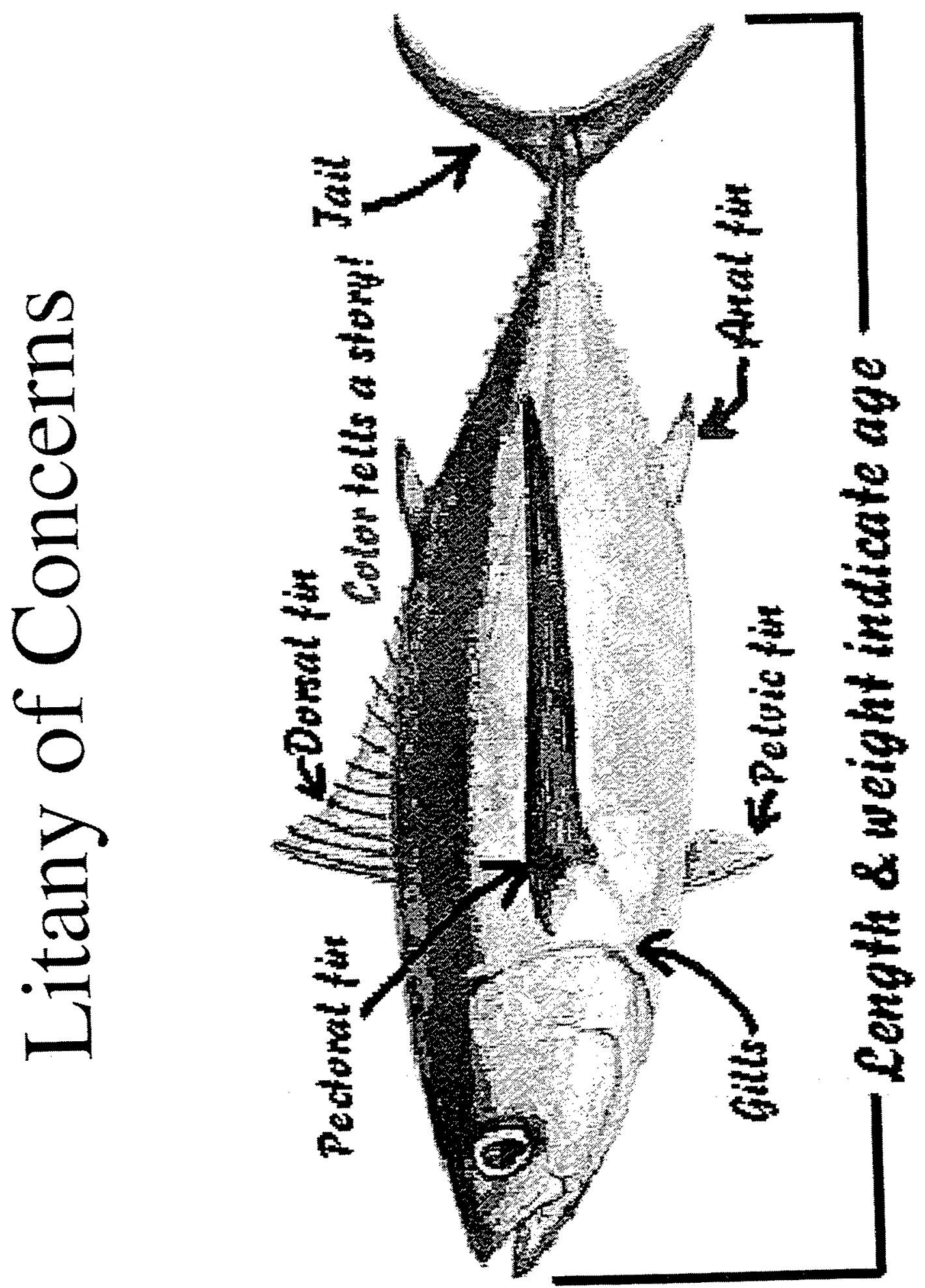


\section{The Litany of Concerns}

- Overpopulation

- Global Warming, Ozone Depletion

- Resource Scarcity (Water, Overfishing)

- Environmental Damage (Pollution, Deforestation, Endangered Species, Bio Invasions)

- Migration, Disease

- Remember the Limits to Growth? 


\section{Normative Bias}

- Existing Studies "Problematize" Issues

- Condemn Existing Policies

- Condemn Governments

- Provide Solutions?

- Strategy is Normative

- But Empirical Issues Predominate

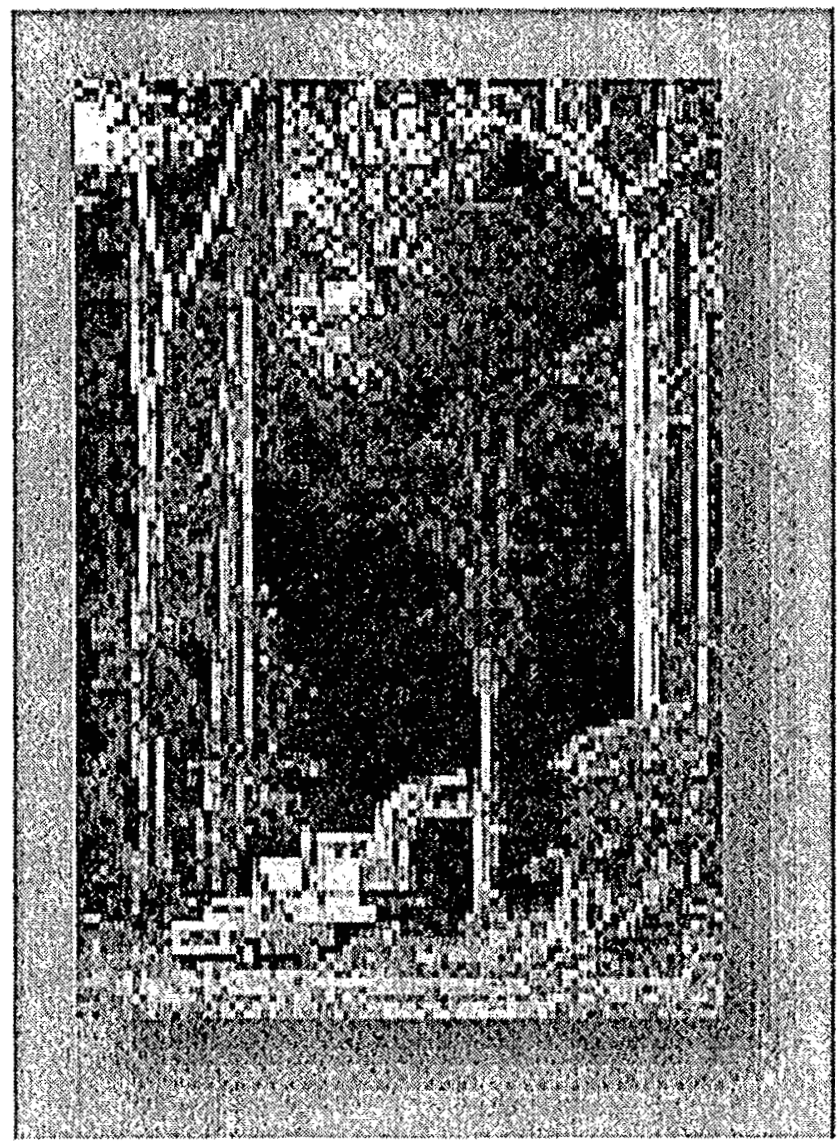



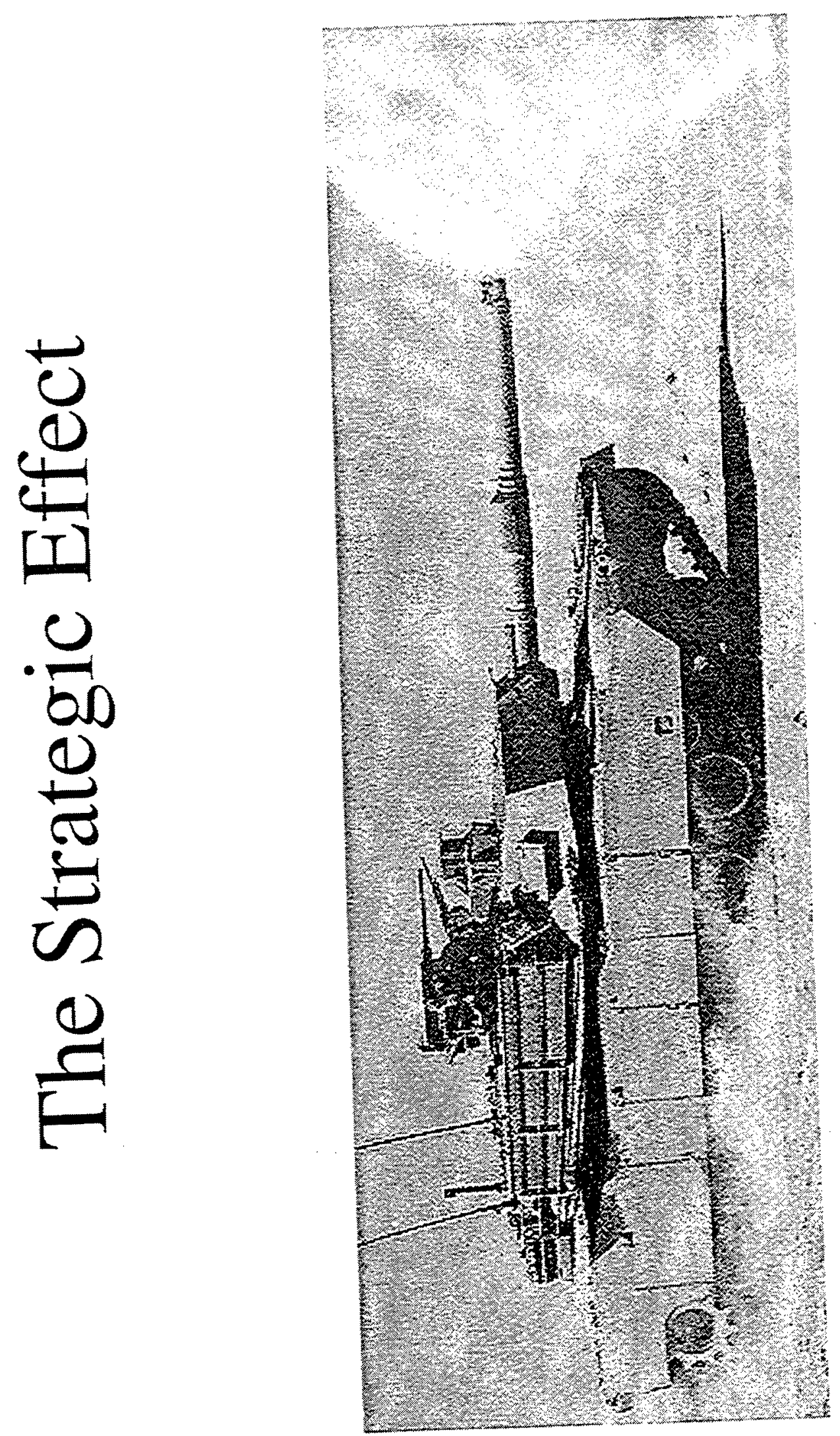


\section{Strategic Effect}

- What is the Strategic Effect of these Trends?

-Will they Become "Military" Issues?

- Or simply assume that they will?

- Will they Shape Strategy - "Population"

- Restless Hoards

- "Little Princes"

- Geriatric Nations 


\section{Preliminary Observations}

- People who Worry About the Environment ....

- If Current trends continue....

- How will these issues shape strategy?

- Have they already?

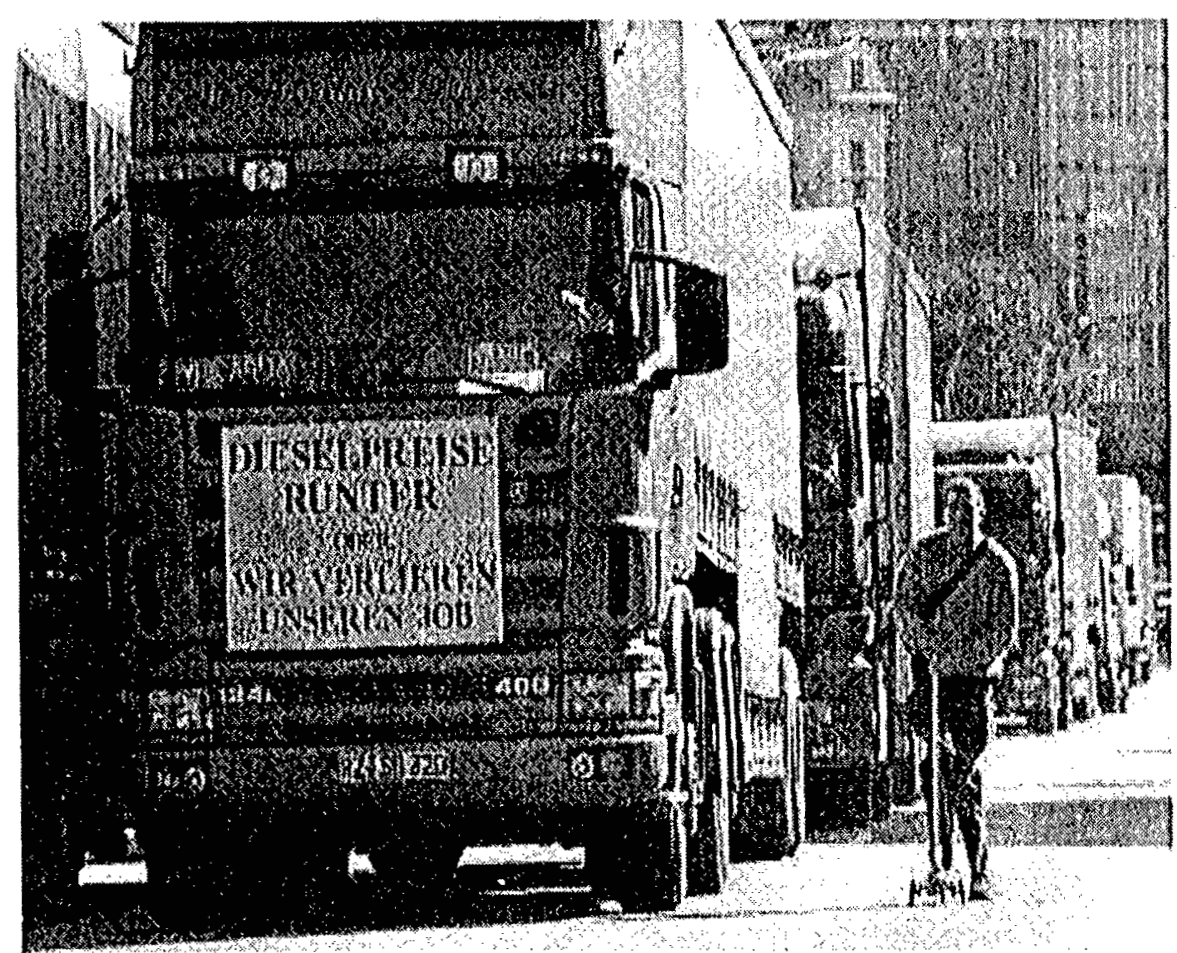




\title{
WHAT IS STRATEGIC STUDIES A ND DOES IT HAVE A FUTURE?
}

\author{
Lawrence Freedman
}

Strategic studies developed outside of the universities. Before the cold war there were military theorists and commentators, such as Boney Fuller and Liddell Hart in Britain, who often had substantial practical experience of the subject but who wrote largely for a popular and a professional audience rather than an academic. Their subject matter was similar to that of later strategic studies, and those that survived into the nuclear age fitted in perfectly well with the new milieu. There was some pioneering activity in the universities after the first world war with the moves to establish the scientific study of international affairs as a contribution to the avoidance of future wars. Many of those in this field had an interest in military matters although few claimed expertise in how best to fight wars, and, as will be discussed below, the bias in the discipline was to some extent anti-strategic.

The special flavour of post-war strategic studies came from those who had been working in the physical sciences and engineering rather than the social sciences and humanities, many with their consciences stung and their policy interest engaged through the Manhattan Project. Those that had worked on operational problems from convoy protection to choosing targets for air raids had firm views about how the conduct of war could no longer be left to what they often took to be the rather primitive, intuitive forms of reasoning of the professional military. The conviction that civilians had critical contributions to make to strategic policy grew as traditional military patterns of thought appeared as being quite inadequate in the thermonuclear age. The combination of the arms race and the cold war created the conditions for the growth of a substantial researchled policy community outside of the universities - new government agencies, congressional committees, think-tanks and 'beltway bandits.'

This created a market for professionally trained civilian strategists that university departments might attempt to fill. It also meant that academics were never able to 
impose a scholarly framework for the subject that could survive independently shifts in the policy framework. Few really tried to do so. From the start it was the salience of the policy issues rather than intellectual curiosity that led to the growth of the strategic studies community. The universities were certainly not hostile to policy-led research. The cold war coincided with the expansion of the universities throughout the western world not only in size but also in the range of their activities. They took in subjects that were often practical in nature and moved well beyond established disciplinary boundaries. If gender and the media could become appropriate subjects for university departments then it would have been surprising if questions of armed force had escaped the net. More seriously those making the case for higher education were pleased to have examples of contributions to national strength. When the universities went to the US Congress for more funds after the Soviet had apparently rushed ahead in the technological race with the launch of the world's first artificial satellite (Sputnik 1)their case was made in the name of national security. Many academics thrilled to a potential role in a wider public debate, even if this meant enduring snide remarks about abstract theorising removed from real life, and certainty that their weightier tomes would be left unread while their short, snappy opinion pieces might reach presidents and prime ministers. Academic exponents of strategic studies might have had much more training in the of use evidence and sophisticated forms of analysis but they could still drift easily into advocacy, preferring popular and professional audiences to the dustier academic conferences.

Little attempt was made to use the cold war opportunities to establish strategic studies as an academic subject. No core curriculum was developed, and there was probably only a brief period in the early 1960s, the end of what was later described as the 'golden age,' when there was a seriousbody of literature with which everyone in the field was reasonably familiar. There was not even a consensus on how academic work in this area should be described. The policy influence was always apparent. 'Military studies' appeared too technical and narrow, redolent of map-reading and staff exercises, and contradicted the factors that had shaped the civilian role in strategic policy: the prejudice against professionalmilitary thought; the democratic conviction that at any rate the military sphere should be subordinated to the civil: and the Clausewitzian presumption that if, as the master insisted, war is concerned with the pursuit of politics 
by other means, then military means could only be properly understood by reference to political purposes.

\section{IN AND OUT OF THE COLD WAR}

But what political purposes? As, at least at the governmental level, the ends of policy seemed somewhat fixed during the cold war, the focus was very much on means. The contest between liberal capitalist and state socialist forms of government was inescapable. The central problem of policy was awesome in its implications but also relatively simple in its formulation. The basic issues were of deterrence: in what circumstances would nuclear threats work and what would be the consequencesif they failed to do so or were counter-productivein their effects? How could political benefit be extracted from a nuclear arsenal without triggering a cataclysmic conflagration? How could credibility be injected into preposterous posturing? The natural inclination of academics was to explore these paradoxes. This could be done both by exploring ways by which deterrence could be reinforced, thereby avoiding war, but also ways in which other policy instruments might reduce dependence upon this high-risk approach. They became interested in particular in arms control. Over time this had an important consequence in that it encouraged a perspective that went beyond the purely national to the systemic. Rational Soviet policies became as important as rational American. A rational American policy should be designed so as to coax out of Moscow a more rational Soviet policy.

The changes in the character and tempo of the cold war naturally influenced strategic studies. After the Berlin and Cuban crises of the early 1960sfurther development of the purer theories of deterrence seemed less important. Academics began to find a role in questioning official policy and warning of the limits to deterrence, the distorting effects of domestic and organisational politics on crisis management and the perils of misperception. The second-ordertechnical studies sought to offer ways out of practical difficulties experienced in arms control negotiations. A further development came as it was recognised that too much of the 'golden age' literature had taken the political context for granted, or had at least failed to appreciate the dynamic consequences of the 
upheavals in the third world. AfterVietnam these aspects of strategy were much harder to ignore. To under the conditions in which armed forces might be used, or at least threatened, it was necessary to delve into a diverse range of regions. It seemed more important to draw attention to the complexities of the Middle East or Central America than to think up fancybut safeways to threaten Armageddon. Furthermore, as even official deterrence policies moved to reduce their nuclear bias and strengthen the conventional elements, professionalmilitary knowledge and experience appeared much more relevant. So well before the end of the cold war the field of strategic studies (now as often known as security studies) had became much more diffuse. There was no recognised academic discipline, only a broad area of study, studied under a variety of headings (peace, war, defence, security, strategy, arms control). The only unifying factor was that the interest lay beyond practical matters concerned with the actual employment of armed force to the political purposes for which it might be employed and the political measures that might be adopted either to prevent this employment or to bring it to an end.

In these circumstances it was inevitable that those working in the universities would have to follow the shifts in focus in the wider policy debate. Given the sort of upheavals associated with the end of the cold and its aftermath this was no small matter. When the policy issues of the day moved from such topics as great power confrontation and nuclear arms control to intra-state wars and humanitarian intervention then quite different skills might be thought to be needed. To deal with the old agenda one might hope for scholars with a grasp of traditional statescraft, a knowledge of the political thinking at the highest levels of the worlds key capitals, sensitivity to alliance relations, and a technical understanding of the properties of the critical weapons systems and how they might be employed. Add in such questions as the management of defence budgets and the intricacies of arms control negotiations and it can soon be seen that during the cold war years strategic studies had to draw on a great variety of types of expertise.

Then out goes the cold war and in comes ethnic conflict, carrying with it vast quantities of anthropological and sociological literature, combined with a necessity to follow political developments in small and weak states, whose leading lights are not themselves plugged in to the international policy circuit, dirty little militia wars and problems of humanitarian 
intervention, which have nothing to do with elaborate theories of deterrence. Some argued for an even more complete shift away from the traditional agenda, insisting that the staples of conflict and violence must give way to the far more important factors of environment and economics. A hypothetical university department set up to address strategic studies during the cold war would find that the original inter-disciplinary requirements - polyrnathic enough - were suddenly expanded to absurd lengths.

Not surprisingly, academics often appeared to be as uncertain about the future of the international system and how to handle the new agenda as were the policy-makers. It became even more difficult to give confident advice in the form of three crisp bull points. Policy-makers became impatient with those qualities that academics believe to be those most valuable: long-term thinking, stretching the bounds of the possible and taking complexity as a challenge rather than an excuse for not going into too much detail. Academics in the strategic/security studies field could see their funding in decline and their best work crowded out by partisan clamour, parochial agency interest and the more sensationalist fare on offer. While the pull from the policy world was to go for the simple, snappy and the short-term, the push from the academic world was almost exactly in the opposite direction. The study of international relations, established to address the problem of war, sought to gain respectability by acquiring all the attributes of a proper discipline, including a preoccupation with theory and methodology. Academic advancement has come to depend on 'conspicuous scholarship' - publishing in the right journals, linking relatively innocuous case studies to great theoretical issues and, through extensive footnotes, demonstrating a capacity to reference (though not necessarily to read) all potentially relevant literature. To those for whom language itself has become an ideological battlefield, and all empiricism suspect, policy relevance signifies the antithesis of sound scholarship and not its highest aspiration.

\section{THEACADEMIC AND POLICY WORLDS}

The relationship between the academic and policy worlds is fraught with ethical and practical difficulties - balancing the need for access and the desire for influence with the 
risk that critical faculties might be blunted and intellectual integrity corrupted in the search for preferment. The academic may not want to help the Practitioner, perhaps disapproving of the basic objectives being pursued. In terms of defining a field of study the vantage point of a student of strategy is quite different from that of a practitioner. When the former tried to second-guess the latter in an effort to display some superior wisdom, then it may well deserve to be treated with contempt. The most helpful role remains that can be properly described as 'academic' (eventhough in the policy world this is all too often synonymous with irrelevant). The task is to conceptualise and contextualise rather than provide specific guidance. If it is done well then the practitioner should be able to recognise the relevance for whatever may be the problem at hand.

Strategy is rarely a-theoretical in practice. The theories may be implicit and undeveloped, following Keynes' famous observation:

Practical men, who believe themselves to be quite exempt from any intellectual influences, are usually the slaves of some defunct economist. Madmen in authority, who hear voices in the air, are distilling their frenzy from some academic scribbler of a few years back.

Yet is it the case that academic theory, even of the highest quality, is of great value to the 'practical man'? The complaint might be that academic works rarely address his problems in the form that he faces them. He has little choice but to range far and wide because of the nature of the judgements he is required to make, often in a hurry. It may be necessary to address the efficiency of various forms of coercion as well as inducements, and in so doing to draw on views about human nature under stress, problems of organisation of large groups of people on the move, negotiating techniques, visions of a good society and standards of ethical conduct.

Consider a general entering into battle. He must consider:

- politics (how best to define the goal of the campaign, the importance of keeping allies sweet, what the people back home will stand),

- engineering (how well the weapons work are likely to work in practice, possible modifications to suit local conditions, ensuring that they are properly maintained),

- sociology (the likely cohesion of the enemy force under fire), 
- psychology (how to motivate his own men, getting into the mind of the enemy commander),

- geography (the possible impact of terrain on particular tactics),

- history (what other generals got away with in similar circumstances),

- economics (the rate at which he dare expend materiel on specific targets),

- and so on.

Note that all these considerations apply only to getting the best out of one's own side. Add the need to think about an enemy and even more types of issue have to be factored into the strategic deliberations.

Furthermore the 'practical men' can expect to be judged by results. They will therefore tend to rely on what works for them. This may be intuition and hunch, or lessons drawn from searing experience or remembered bits of history. These may be relied upon in preference to excellent information sources and exemplary staff work. When matters are finely balanced but a decision has still to be taken, a feeling about the issue may be as good a guide as any. This may strike an academic as being wholly inappropriate or based on disgracefully exaggerated generalisations. Certainly the results from such approaches can be very poor. But whether a proper academic methodology would do any better is moot when there is no time for long projects and there can be little tolerance of lots of caveats. Wise strategists may research their decisions as much as possible, but time often precludes further deliberation. When a general is wondering whether an enemy formation might break in the face of a sudden attack he is not going to be impressed if told that more research is needed or that his working hypothesis is inherently untestable. Once a fateful decision has been taken, an open mind becomes a luxury for any reappraisal may result in confused orders and demoralisation.

The 'practical man' offers another observation. Strategic practice, as opposed to the theory, demands risk-taking on behalf of a wider constituency, normally with the lives of service personnel and possibly with whole societies, and this brings with it certain responsibilities. It involves mobilising human and material resources according to a developed plan against anticipated opposition and in pursuit of stated objectives. If the objectives are misplaced, the plan mis-conceived, the resources unavailable or poorly mobilised then the strategy will fail and this will be the strategist's responsibility. It is this 
sense of being tested by practice and judged by results that gives strategic reasoning its edge.The unaccountable academic should properly feel a degree of humility when advising on such matters.

This may help explain why the study of strategy is accommodated only with difficulty in academic life. As practice it provides opportunity for chance and irrationality to hold sway. The purist might be appalled at the arbitrary mixture of politics, sociology, economics, psychology and history that regularly influence decisions in crisis and combat, never mind the great contributions made by intuition and hunch. Yet the fact that reality rarely shows respect for disciplinary boundaries might give the academic pause for thought, as might evidence of the extent to which carefully qualified propositions, excessively careful formulations and a reluctance to pronounce until all possible avenues of research have been exhausted can get in the way of clear thinking.

Effective policy outside of academia draws on a range of considerations that within academia are each confined to its own disciplinary box. Intellectual progress is assumed to depend on commonly accepted methodologies being rigorously applied within a known conceptual framework to produce results able to withstand peer review. The process is watched over sternly by professional associations and journal editors. They ensure that standards are maintained so that progress can be measured. Without the disciplinary boxes it could well be that teaching and research would become unmanageable. Nonetheless, disciplinary boundaries are often artificial, and sustained through jargon that excludes the uninitiated. Indeed academics often develop particular strategies to sustain these disciplinary boundaries and to fight off intellectual intruders. Yet many of the most important academic cleavages cut across these boundaries. Fads and fashions - from rational actor theory to deconstructionism - migrate easily. Often the most innovative and influential figures are those that refuse to be confined by the established boundaries, but are happy both to borrow from others. Imaginative academic administrators often ignore them. In universities as in other organisations the closer one gets to a particular decision, issues become much more complex and problems can rarely be encapsulated in the terms of a single discipline. Life is inter-disciplinary. 
Strategic studies poses a particular challenge to the social sciences. It tends to adopt the perspective of individual actors within the system, as they try to make sense of their environment and shape it to their needs as best they can. Much social science theorising necessarily seeks to reduce the importance of human agency - by looking for patterns and regularities in areas which we might have thought in our naivety to be governed by choice. Deliberate political change is still inadequately studied in political theory except in a rather cynical way. There is no point in studying strategy unless one believes that the course of history can be altered by the choices made by individuals.

Those who believe that the analysis of politics and international relations requires attempts to identify long historical cycles or universal laws of political life or invariable patterns of behaviour or structural determinants of actions that leave little scope for local decision are unlikely to find strategy particularly interesting or even relevant. Instead of finding anomalous behaviour intriguing they may find it iritating because it undermines the predictive power of their models. Even those who make little pretence to science, and follow the traditions of political theory, often seem preoccupied with taming power, to render it accountable and its operations predictable. Yet without the imaginative use of power little can be done for good, as well as evil, and history would well and truly come to a grindinghalt.

Strategy is important only if it is believed that individuals, groups, governments face real choices - to the extent that the reasoning which informs these choices is worthy of careful examination. By focusing on actors within the system and their sense of their own interests and aspirations, strategic studies must be seditious. It encourages the analysis of those situations where order is absent or else where disorder is encouraged by those who believe that it will be to the advantage of those on whose behalf they are acting.

\section{THE STUDY OF STRATEGY}

This appreciation - almost celebration - of choice is essential to the study of strategy. Strategy is undertaken in the conviction that it is possible to manipulate and shape one's environment rather than simply become the victim of forces beyond control. For this 
reason, students of strategy are naturally political voyeurs, observing the choices of others with a discerning eye, whether or not they have sympathy with their ultimate aims, assessing the efficiency of various forms of coercion as well as inducements, developing and refining views about such things as human nature under stress, the organisation of large groups of people on the move, negotiating techniques, visions of a good soaety and standards of ethical conduct.

For this reason it might be argued that there is no reason in principle why strategic studies, defined as an intellectual approach to certain types of problems rather than a field of study, could not become more prominent in the academic life. Indeed we know this to be the case. Many of the more formal methodologies, of which the most famous remains game theory, developed in the late 1950swere developed with nuclear deterrence in mind and were responsible for promoting the basic insight that antagonists could have shared interests. They have now become even more influential in economics and management studies. There are now far more courses about strategy in management departments than in international relations departments. Intriguingly, the classical military strategists - Sun Tzu more than Clausewitz - loom large in the management literature, far more so than the business strategists loom in the military literature. One unfortunate effect of this development is to encourage the view of strategy as being concerned with more visionary planning or the management of large organizations in uncertain environments rather than inter-dependent decision-making.

Within international relations departments courses on strategy may suffer from association with what is now assumed to be a hopelessly old-fashioned 'realist' preoccupations with the state and military power, often derided for failing to consider domestic and transnational factors, or even peaceful means of exerting influence and resolving disputes. The attack on realism often goes beyond the assumptionsit is believed to embody to its readiness to legitimise armed force as an acceptable instrument of policy. The more radical approach argues for focusing less on what makes states secure and more on what made individuals and particular groups secure. This supports the case for a new agenda dominated by concerns over human rights, world poverty and the environment. The argument over the status of realism has encouraged a tendency to caricature (unfortunatelyoften abetted by self-styled realists), so that an 
approach to political analysis that prided itself on coming to terms with the world as it was rather than as idealists would like it to be is now supposed to depend on a dubious claim that key international events can largely be explained by the structurally-defined means by which states must safeguard their security. By contrast a non-dogmatic realism would acknowledge the significance of non-state actors, the impact of social, economic, cultural and local political factors on state behaviour, the importance of values and mental constructs, and can be sensitive to the epistemological issues raised by presumptions of objectivity. If practitioners of international politics now talk regularly about issues of identity, norms and globalization then they are part of international reality.

That argument might be taken further to argue that the business of states, often described as issues of security, now takes in far more than armed forces but also much wider economic, social and environmental factors. To what extent might these be legitimate areas for strategic studies? At one level they are vital to the traditional preoccupations with questions of armed force. These factors influence the course and character of all conflicts, even when they have reached their most violent forms. Strong rates of economic growth and forms of interdependencemay well reduce tensions between states and create a stake in peaceful coexistence. Environmental disasters can undermine the credibility of the state apparatus so that it becomes vulnerable to other types of challenges. Changes in family structures and social mores may affect attitudes to violence, and so on. An awareness of these issues is essential to any attempt to make sense of the changing state system.

That is not the same as saying that issues of armed force have largely become, at least as far as the western world is concerned, of marginal interest, so that strategic studies needs to retool to address economic, environmental and social issues directly. Politicians may dramatise the more troublesome social problems by calling for 'wars' against them (on drugs, cancer, etc.) and suggest that strong generalship is needed for them to be defeated. The unreflective application of the war analogy can hinder understanding by attempting to squeeze quite different types of issues into an inappropriate conceptual framework geared to military threats. In the case of drugs, for example, it may have some relevance to confrontations with third world drug cartels 
but less so with attempts to make sense of patterns of consumption. Equally the notions of 'economic security' can encourage a confrontational approach to trade policy and 'environmental security' a search for explanations based on hostile actions rather than natural causes or everyday economic activity. Even more difficult is a term such as 'internal security' which might once have referred to the ability of states to deny armed groups, whether criminal or political, the ability to challenge their authority, but which now takes in anything to do with the control of borders, including economic migration or the smuggling of contraband.

If, as argued earlier, much of the fascination of strategy is with the exercise of power, then there is an unavoidable strategic dimension to all policy areas - how to mobilise support, sideline opponents, ensure effectiveimplementationand so on. This is why it is a fit subject for management schools. Nonetheless it would be unfortunate if those working in this field abandoned their special concerns with issues of armed force. The characters and competences of states may have been subject to many changes but an enduring feature remains the aspiration to define and dominate the means of legitimate violence within territorial borders. The challenges can come from other states, or from within states in the form of secessionists or revolutionaries or elitist conspirators, or from non-state actors in the form of drug cartels and gangsters, religious sects and minority political movements. This provides an enduring and relatively sharp focus for strategic studies and provides some compensation for an unavoidably wide context.

Even in terms of the development of a general theory of strategy, capable of addressing all manner of political situations, there is a case for continuing to pay the closest attention to issues of armed force. If strategy is about choice then armed force provides some of the most perplexing and starkest choices that can be confronted. At these points of choice can be observed clashes between conflicting interests and values, the rough impact of brute force and the more subtle effectsachieved by guile and wiles. It is the case that most political objectives can be met without the use or threatened use of violence. There are other sources of power. But physical violence is the ultimate and, if available, can overwhelm all others. The threat posed is one that no individual or group or state can ignore because it challenges their whole existence. It is one that is only likely to be made when basic values are at stake, and this is by definition the case for those on the receiving 
end. Situations involving the purposive use of violence are likely to stand out from the run of the mill activities at both the national and international levels. By their nature they concentrate minds on fundamentals.Ethically and politically they require exceptional justification. For all these reasons they provide a natural starting point for any attempt to build up a general theory of strategy.

Whether a general theory of strategy can sustain departments of strategic studies must be doubted. Even if one could be agreed its value would be in influencing the understanding of the exercise of power in all areas of human activity and should not therefore be confined to one department. To the extent that academic institutions remain committed to the area of study that has hitherto been covered by strategic studies (under its many headings) it is most likely that they will be carried forward by a developing policy agenda rather than intellectual agenda. The prospect is therefore that it will become more rather than less diffuse, and may well struggle to hold on to its traditional concern with questions of armed force. 
$\underline{\text { Distribution List }}$

Defense Technical Information Center 2

Library, Naval Postgraduate School 2

Gordon Schacher,IJWA, NPS 1

James Wirtz, NSA, NPS

Bob VanZandt, J9, JFCOM 5

COL Chris Shepherd, J9, JFCOM 1

Raquelle Hill, J9, JFCOM 1 


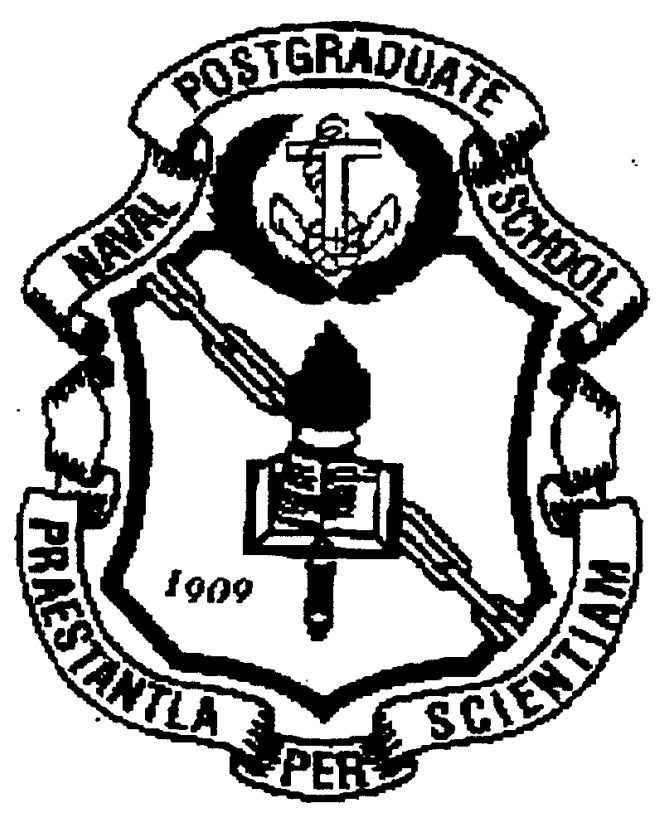

Naval Postgraduate School Monterey, California 